University of Rhode Island

DigitalCommons@URI

Open Access Master's Theses

1975

\title{
South American Backstrap Loom: Its Potential, Limitation and Application for Contemporary Handweaving
}

Rosa Will Abboud

University of Rhode Island

Follow this and additional works at: https://digitalcommons.uri.edu/theses

\section{Recommended Citation}

Abboud, Rosa Will, "South American Backstrap Loom: Its Potential, Limitation and Application for Contemporary Handweaving" (1975). Open Access Master's Theses. Paper 771.

https://digitalcommons.uri.edu/theses/771

This Thesis is brought to you for free and open access by DigitalCommons@URI. It has been accepted for inclusion in Open Access Master's Theses by an authorized administrator of DigitalCommons@URI. For more information, please contact digitalcommons-group@uri.edu. 


\section{SOUTH AMERICAN BACKSTRAP LOOM}

ITS POTENTIAL, LIMITATION AND

APPLICATION FOR CONTEMPORARY

HANDWEAVING

BY

ROSA WILL ABBOUD

A THESIS SUBMITTED IN PARTIAL FULFILLMENT FOR THE REQUIREMENTS FOR THE DEGREE OF

MASTER OF SCIENCE

IN

TEXTILES, CLOTHING, AND

RELATED ART

UNTVERSITY OF RHODE ISLAND

1975 
MASTER OF SCIENCE THESIS

OF

ROSA WILL ABBOUD

Approved:

Thesis Committee:

Major Professor

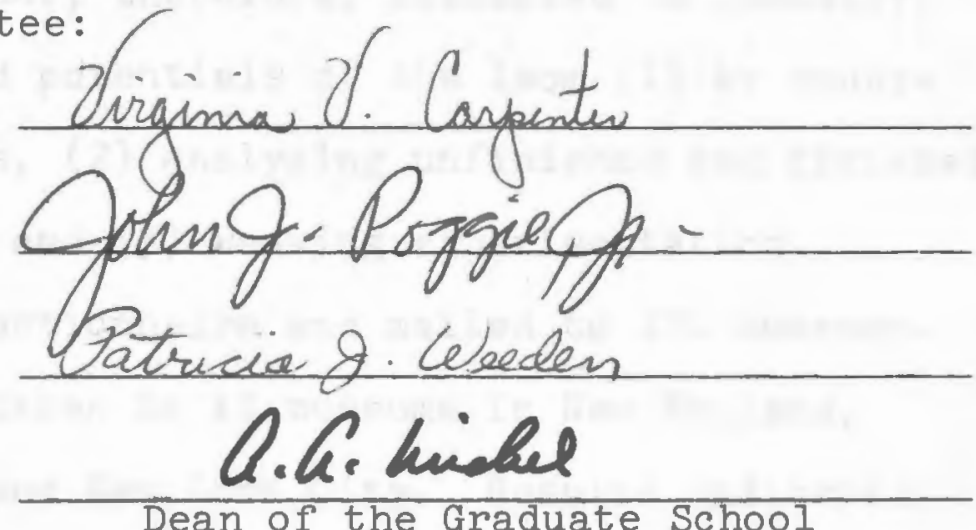

UNIVERSITY OF RHODE ISLAND

1975 


\section{ABSTRACT}

Backstrap-loom-weaving appeals to the contemporary artist. Simple in equipment, highly flexible in use, it offers possibilities for rendering designs that are only limited to the ingenuity of the artist.

The loom, currently used in various forms by primitive people, was the major weaving tool of the pre-Columbian Peruvians, who excelled in the textile arts and are praised for their extreme skills, and wide range of practiced techniques. Research, however, indicated that the loom might not permit all varieties of weave structures and weaving techniques.

The researcher, therefore, attempted to identify the limitations and potentials of the loom (1) by studying weave structure, (2) analyzing unfinished and finished textiles on looms, and (3) weaving experimentation.

A survey questionnaire was mailed to 174 museums. Research was undertaken in 11 museums in New England, Washington, D.C., and New York City. Results indicated that (1) except for Dr. Junius B. Bird's extensive collections at the American Museum of Natural History, New York, the number of intact and unhampered looms was few, (2) weave types other than plain, warp and weft patterning are limited 
to leno, double cloth and twill with no more than four or five shedding divisions. Although not a common practice, heddles did advance to counter heddles in Peru and twin heddles in Central America.

Through experimental weaving it appeared that weaving to shape, with four selvages, and crossing of warp yarns were potentials of the loom which derive from the absence of the reed and the flexible set-up of string heddles. Setting up the loom for weaving with multi-heddles poses a limitation which either requires a higher manual manipulation of the warp yarns as done by the Peruvians, or advanced planning of the warping procedure and simplifications of weave drafts as proposed for contemporary handweaving. Finally the minimal requirements on the loom parts and its assemblage make the loom extremely economical and highly transportable. 


\section{AC KNOWLEDGEMENTS}

I wish to extend my gratitude to the thesis committee: Professors Virginia V. Carpenter, Mary J. Gilbert, John J. Poggie, Jr., and Patricia J. Weeden for their guidance during this research. Also, I wish to thank all those who, associated with museums, kindly answered my inquirles provided information, photographs or suggestions for further sources of information, or permitted me to study and photograph pertinent specimens in their collections. 
TABLE OF CONTENTS

CHAPTER

PAGE

I. INTRODUCTION . . . . . . . . .

II. DISTRIBUTION, TYPES AND TECHNICAL FEATURES OF IHE BACKSTRAP LOOMS $\bullet \cdot \bullet \cdot \bullet \cdot \cdot \cdot \bullet$

III. BACKGROUND INFORMATION ON THE PERUVIAN

BACKSTIRAP LOOM $\cdot \bullet \cdot \cdot \cdot \cdot \cdot \cdot \cdot \cdot \cdot \cdot 14$

PERUVIAN CULTURAL HISTORY . . . . . 14

PERUVIAN TEXTILES . . . . . . . . . 21

ARCHAEOLOGICAL AND ETHNOLOGICAL LOOMS • 27

IV. METHODS . . . . . . . . . . 33

V. RESULTS AND DISCUSSION OF LITERARY

RESEARCH, MUSEUM VISITS AND EXPERIMENTAL
WEAVING $\cdot \bullet \cdot \bullet \cdot \cdot \bullet \cdot \cdot \bullet \cdot \cdot \bullet$

DEVELOPMENT OF THE PERUVIAN BACKSTRAP

LOOM . . . . . . . . . . . •

POTENTIALS AND LIMITATIONS OF THE

BACKSTRAP LOOM . . . . . . . . 44

Loom Set-up • • • • • • • • 44 Warping, Weaving width and length, Attachment of warp to loom bars, Side selvages

Absence of Reed . . . . . . . . Density or sett, Deflected warp yarns, Interlocked warp yarns, Loom shaping, Gauze

Heddle System •. • . . • • . . 105 'Will, Satin, Multiple and double cloth

VI. SUMMARY AND CONCLUSIONS . . . . . . 157 FOOTNOTES .................. 161

BIBLIOGRAPHY . . . . . . . . . . . 170 APPENDICES .................... 174 


\section{LIST OF ILLUSTRATIONS}

Figure

1. Geographical Distribution of Backstrap Looms and Heddle Types . . . . . . . .

2. Loom Types . . . . . . . . . . 176

3. Warp Arrangement and Effect on the Finished Woven Product .............

4. Shedding Devices Used with the Backstrap Looms

5. String Heddle Types .......... 181

6. Current Distribution of the Backstrap Loom in South America.......... 184

7. Types of South American Backstrap Looms • 185

8. The Peruvian Backstrap Loom . . . . . . 9

9. Archaeological Sites ......... 188

10. Peruvian Textile Techniques . . . . . 189

11. Yarn Distribution of Peruvian Textiles . . 22

12. Contemporary Spinning Tools: Whorl Spindle and Shuttle ..............

13. Archaeological Spindles . . . . . . 193

14. Distribution of Weaving Techniques..... 25

15. Native Style Looms of Peru Highlands . . . 195

16. Tapestry Loom from the Late Period . . . . 196

17. A-Frame Loom . . . . . . . . . . 196

18. Silver Toy for a Girl Representing a Loom . 197

19. Multiple Heddle Belt Loom . . . . . . . 198 
20. Present Day Belt Loom with Warp-Faced Twill • 198

21. Inca Weaving, Mochica Type Loom .... . . 199

22. Weaving Scenes from a Pottery Vessel of the Mochica Culture............ 199

23. The Peruvian Looms from the Earlier and Later Periods . . . . . . . . 200

24. Peruvian Loom with Pattern Sticks for Pattern Weaving ............ 201

25. Mislabeled Specimen . . . . . . . 231

26. Old and Present Day Shape of Loom Bar . . . 38

27. Archaeological Loom Found in Near Perfect Condition ........... 40

28. Ancient Double-Cloth Loom at Time of Acquisition ............ . 41

29. Ancient Double-Cloth Loom, Restored . . . 42

30. Present-day Double Cloth Looms . . . . . 43

31. Preparation of Warp on a Warping Board, Guatemala......... . 47

32. Warping Techniques, Guatemala ....... 45

33. Warp Set-up, Pachacamac . . . . . . 47

34. Warping Paddle ........... 47

35. Wide Backstrap Loom . . . . . . . . 50

36. Methods of Attaching the Continuous Warp to Loom Bars............. . 52

37. Methods of Attaching Warp to Loom Bars . . 53

38. Loom Set-up . . . . . . . . . . 56

39. Side Selvages........... 59 
40. Warp Densities .......... . 61

4l. Yarn Slippage . . . . . . . . 63

42. Ethnological Loom with Tenter . . . . . 64

43. Experimental Weaving of Swedish Lace on Backstrap Loom............ .

44. Gauze Woven with Crepe Yarns . . . . . .

45. Experimental Weaving with Low and Hightwist Yarns ...............

46. Deflected Warp Yarns ...........

47. Supplementary Warp Yarns . . . . . . .

48. Types of Warp Interlocking . . . . . . 70

49. Interlocked Brown and White Warp Yarns...

50. Set-up of Discontinuous Warp Yarns . . .

51. Loom with Interlocked Warp Yarns . . . .

52. Loom Shaped Weaving . . . . . . . 76

53. Loom Shaped Weaving . . . . . . . . . . 77

54. Loom Shaped Weaving .......... 78

55. Loom Shaped Weaving .......... 81

56. Shaped Garments ........... . 82

57. Addition of Warp Yarns . . . . . . . 86

58. Shaped Weaving ............ 86

59. Shaped Scarf Experimental Weaving (Student's Work) ................ .

60. Arica Shirt ............. 89

61. Shaped Weaving with Superimposed Warp ... 91

62. Loom Shaped Weaving . . . . . . . . 92 
Figure

Page

63. Loom Shaped Tapestry Shirt .. . . . . 93

64. Experimental Weaving .......... 96

65. Types of Gauze . . . . . . . . . . 97

66. Frequencies of the Four Gauze Types among

Peruvian Textiles .......... 98

67. Plain Weave with Gauze ......... 101

68. Breech Cloth .......... 101

69. Tapestry Techniques on Gauze ....... 101

70. Warp Control for Plain, Alternating Gauze • 99

Loom with Gauze .......... 102

71. Warp Control with Plain Gauze . . . . . 102

Chancay Valley Tapestry on Gauze . .... . 103

Warp Control of Plain, Alternating Plain

and Complex Gauze ........ 104

72. Experimental Weaving of Gauze ...... 105

73. Distribution of Twill Weave to Period ... 108

74. Twill Woven by Cashinana Indians . . . . 111

75. Contemporary Twill Band ......... 111 Weave Draft of Twill Band . . . . . . . . 111

76. Doll Weaving Tunic Woven in $2 / 2$ Diamond

Twill ............ 112

77. Weave Draft of $2 / 2$ Diamond Twill ..... 113

78. Mummy Wrapping ........... 115

79. Weave Draft ............ 114

80. Broken 2/2 Twill, Ancon ........ 117

81. Weave Draft of Broken 2/2 Twill, Ancon . . 116

82,
83. Face and Reverse $-1 / 3-3 / 1$ Turned Twill .. 119 
Figure

84. Overall View of Patterned Twill ...... . 121

85. Weave Draft.............. 121

86. Reconstruction of a Two-color Twill

(Diagram) .............. 122

87. Small Sample Loom with Band in Two-color

Twill .. . . . . . . . . 123

88. Reconstruction of Twill Weaves ...... 123

89. Experimental Weaving of Satin Weave . . . 126

90. Double-cloth Loom, Cora Indians, Mexico . . 130

91. Warp Control for Double-cloth Weaving . . . 132

92. Replica of Peruvian Double-cloth Loom . . . 134

93. Warp Control of Truman Bailey Loom . . . 135

94. Weaving Double cloth in Peru . . . . . 136

95. Double-cloth Loom, Amano Museum ... . . 137

96. Double-cloth Loom . . . . . . . . 138

97. Double-cloth Loom Restored ........ 140 At the Time of Acquisition ......... 141 Warp Controls ............. 142

98. Warp Control of Loom . . . . . . . . 139 Double-cloth Loom ............ 143

99. Incomplete Double Cloth ......... 145

100. Incomplete Double Cloth . . . . . . . 146

101. Incomplete Double Cloth . . . . . . . 146

102. Complete Double Cloth . . . . . . . 146

103. Double Cloth and Plain Weave with Paired

Warps ............. 147

104. Supplementary Warp Floats......... 148 
105. Double Cloth and Supplementary Warp Floats - 149

106. Double Cloth, Plain Weave, Supplementary Warp Floats ..... . . . . . . 149

107. Warp-faced Double Cloth with continuous Weft............... 150

108. Double Cloth with Multiple Warp ...... 151 109. Triple Cloth ............. 153

110. Warp Pattern on Loom with Eight-Pattern Heddle Rods and Plain Weave Two-shed Arrangement ............. 154

111. Catalogue Card, Museum fuer Voelkerkunde, Berlin.............. 156 


\section{INTRODUCTION}

During the last decade American handweaving experienced a profound change. Weaving became a medium for the artist. Materials and techniques were considered means for self-expression. Inherent qualities of materials, limitations and potentials of techniques became important to design conception. Also the desire for close contact between artist and material without the complexity of the harness treadle loom led to the revival of techniques usually connected with primitive and prehistoric textiles, such as knotting, finger weaving, and weaving on simple looms. With this revival came a growing interest for the textiles themselves especially the Peruvian pre-Columbian textiles which, predominantly woven on the backstrap loom, were appealing for their designs, colors, high craftsmanship and wide range of techniques. Weaving books began to include references to techniques and designs of Peruvian textiles as well as instructions on how to build a backstrap loom. ${ }^{1}$ Statements indicated that the Peruvians practiced the widest range of textile techniques of any culture, including some techniques which are not in use today, ${ }^{2}$ and "many of the weaving practices cannot be duplicated on today's looms." 3 
Even after discounting any virtuosity of the weaver this would point to a great potential or flexibility of the backstrap loom. This loom is defined as a simple loom "on which warp tension is maintained between the body of the weaver and a stationary object. 14

In opposition to these statements are the observations of handweaver Harriet Tidball who questions the wide range of loom techniques. After pointing out that certain yarn interlacements were not developed or were introduced and abandoned after a short time, she implies that the loom, and in particular the absence of the reed, might have been a limiting factor. 5

The purpose of this research is (1) to study the use, development of the Peruvian backstrap loom and its woven textiles through literary references and museum collections, (2) to identify limitations and potentials of the loom through experimenting with weaving and relating the results to the types of woren textiles found in museum collections, and (3) to explore technical modifications of the loom with regard to ease of use, range and effect of applications for contemporary handweaving. Underlining the planning of the study, the discussion and evaluation is the basic assumption that (1) no matter how great the influence and pressures of the contemporary society are on the style and preference for certain techniques, the technical limitations of materials 
and tools exert an influence on the continued use and further development of techniques, and (2) skills developed through long existing traditions encourage refinements of techniques and elimination of impractical habits.

The study is introduced by a review of literature which begins with the distribution and various types of backstrap looms. After focusing on the South American looms, the study deals with the Peruvian backstrap loom exclusively.

A brief history of the Peruvian cultural history is given to understand better the importance of the loom to the Peruvian textile history. After identifying the technical limitations and potentials of the loom through its structure, the study searches for specimens of looms and textiles in order to illustrate these limitations and potentials. A survey questionnaire sent to museums led to museum visits in the northeastern United States and to correspondence with resource persons. The results of the investigations are supplemented by literary references, especially when the actual research was unsuccessful in finding pertinent specimens. By comparing the results with actual weaving experiments done by the author, possible applications for the contemporary handweaver are identified. 


\section{DISTRIBUTION, TYPES AND TECHNICAL FEATURES OF THE BACKSTRAP LOOMS}

Named the simpliest of all horizontal $100 m s^{6}$ with hardly any requirement for loom material, the backstrap loom was and still is widely used among native people in East Africa, Asia, Oceania, and espeeially in the Americas. ${ }^{7}$ The name refers exclusively to the strap, girdle or belt which passes around the hip or waist of the weaver and is attached to one end of the loom while the other end is tied to a fixed point. The weaver maintains and controls the warp tension with his body. The loom itself and the accessories may vary with custom, needs and local materials. The loom parts fall into three categories, each fulfilling a basic function of the weaving process: (1) to hold the warp ends parallel and taut, (2) to create a shed, or open angle between two planes of selected warp yarns through which the weft is inserted, (3) to push the inserted weft close to the already woven web. Appendix A brings general information on the backstrap looms. Figure 1 shows the geographical distribution of the looms classified by heddle types. Figure 2 illustrates the range of loom types which use a backstrap as a tension device. Figure 3 lists the 
effect of the various warp arrangements on the finished woven product. Figure 4 indicates the limitations which the shedding devices place on the weaving techniques. Figure 5 lists the various string heddle types which were and are used today with these looms.

Looms with a backstrap seem to be indigenous to primitive people all over the world. Generally the loom is simple, easy to use and fast to assemble and disassemble. The most common form is the two-stick or two-bar loom. If one of the sticks is omitted, as in the Ainu loom where long unspun elm fibers are tied to a hook, then a warp spreader or any other device which will spread the warp has to be introduced.

Parts can also perform a dual function as in the Zuni loom where the slot and eye heddle doubles as warp spreader and heddle device.

A certain interrelationship exists between the finished woven product, the warp arrangement and the form of the warp yarn. A continuous warp yarn can produce a woven tube double the length of the assembled loom or woven product with four selvages, with double or single length. It also requires string heddles which can be formed on a stretched warp contrary to the slot and eye heddle and the hole and board heddle which have to be inserted into the warp before stretching. The latter two heddle forms work only with a cut warp. 
The types of string heddles have in common that they are formed with a continuous yarn on an open shed. Also the techniques allow for some adjustments of the heddle length during the lacing while still maintaining an even length during the weaving. All the techniques are extremely simple and easy to apply. They all serve the purpose of lifting up the selected warp yarns evenly and securely. In addition, the spiral heddle can work as a single or twin heddle by either lifting up all the heddles at once or only half of the heddles at one time, front or back. Actually two heddles are combined into one heddle. The chain-stitch heddle is a novel solution for very narrow or very wide webs where a rod is either hard or impossible to use. The chain stitch creates here enough interlaced cord to become a flexible rod.

\section{SOUTH AMERICAN BACKSTRAP LOOMS}

Among all the users of the backstrap loom the ancient and present day Peruvians, Mexicans, Guatemalans achieved the highest weaving accomplishments. With a high technical proficiency, simple and complex weaves were woven on looms with one or three string heddle rods and one shed-roll, with brocading or pattern sticks. In Coban, Guatemala ${ }^{8}$ the backstrap loom is even set up with special heddle strings to weave gauze without pick-up sticks. 
Among the South American Indians the following tribes weave on the backstrap loom: Quechua, Aymara, Jivaro, Piro, Chaco, Chiriguano, Omagua and Cocama. Except for the Peruvians, the Indians exhibit less skilled weaving. Actually many adopted the loom and several techniques from the Peruvians as did the Chacos with the slit tapestry technique and the warp patterning. The Peruvian influence is so pronounced that $O^{\prime N e a l e ~ c a l l s ~ t h e ~ b a c k s t r a p ~ l o o m ~ t h e ~ P e r u v i a n ~}$ loom. 9 Figure 6 shows the distribution of the backstrap loom in South America and Figure 7 illustrates the various types with the warp set-up and heddle lacing. Some tribes weave wide and narrow webs, others only arm and leg bands. The Jivaro are known to weave fine cloth and the Piro only coarse cloth.

The backstrap loom is not exclusively used. The other looms are the horizontal ground loom and the European four harness loom which had been introduced by the Spaniards. And the Iymaras even practice a division of labor which is based on the loom type: the woman uses the backstrap loom, and the man the four harness floor loom. 10

The loom types have one common characteristic: they produce weavings with four finished selvages based on a continuous warp set-up for a ring warp or for double or single warp length. There are variations in the string heddles, and in the fixed objects to which the loom is fastened. 
The Quechua use a house post or a tree, the Jivaros lash the loom to upright posts and the Piros hold the warp bar between the outstretched feet. 11

The present day Peruvian loom consists of the following basic parts: two loom bars and one auxiliary cloth bar for securing the rolled-up woven web, one shed rod, one rod with continuous string heddles, bobbin and sword. The accessories are the tenter for maintaining the uniform weaving width, as well as pattern sticks or pick up sticks for weaving design motives. The warp is continuous, of single warp length and lashed to the loom bars.

Figure 8 is a diagrammatic representation of the backstrap loom by Br. Junius Bird (Courtesy of the American Museum of Natural History):

a, loom bars; b, shed roll; c, heddle rod;

d, batten or sword, e, bobbin; f, backstrap;

g, warp lashing; $h$, heading string; $i$, lease

or laze cord; $j$, leash cord; $k$, warp; 1 , weft.

The diagram shows the heddle-controlled shed open, ready for passage of the bobbin $(e)$. After pressing the weft in place the sword is withdrawn and the opposing shed is partially opened by pulling the shed rod (b) toward the weaver. A wider opening allowing for the return of the bobbin (e) is achiered by inserting the sword (d), and turning it on edge. Warp tension is varied for the different movements. 12

The weaving starts at the loom bar closest to the weaver and proceeds away from the weaver for about one to two inches. Then the loom is turned around, and the already woven web will function as a warp spreader. The weaving begins again and forms a new selvage at the former warp 
bar which is now the new cloth bar. The weaving will proceed until both woven webs meet. Thereafter the shed opening becomes smaller and smaller; the thick shed rod, and the heavy sword have to be substituted with narrower tools. And at the join or end of the weaving, the weft is inserted with a long needle.

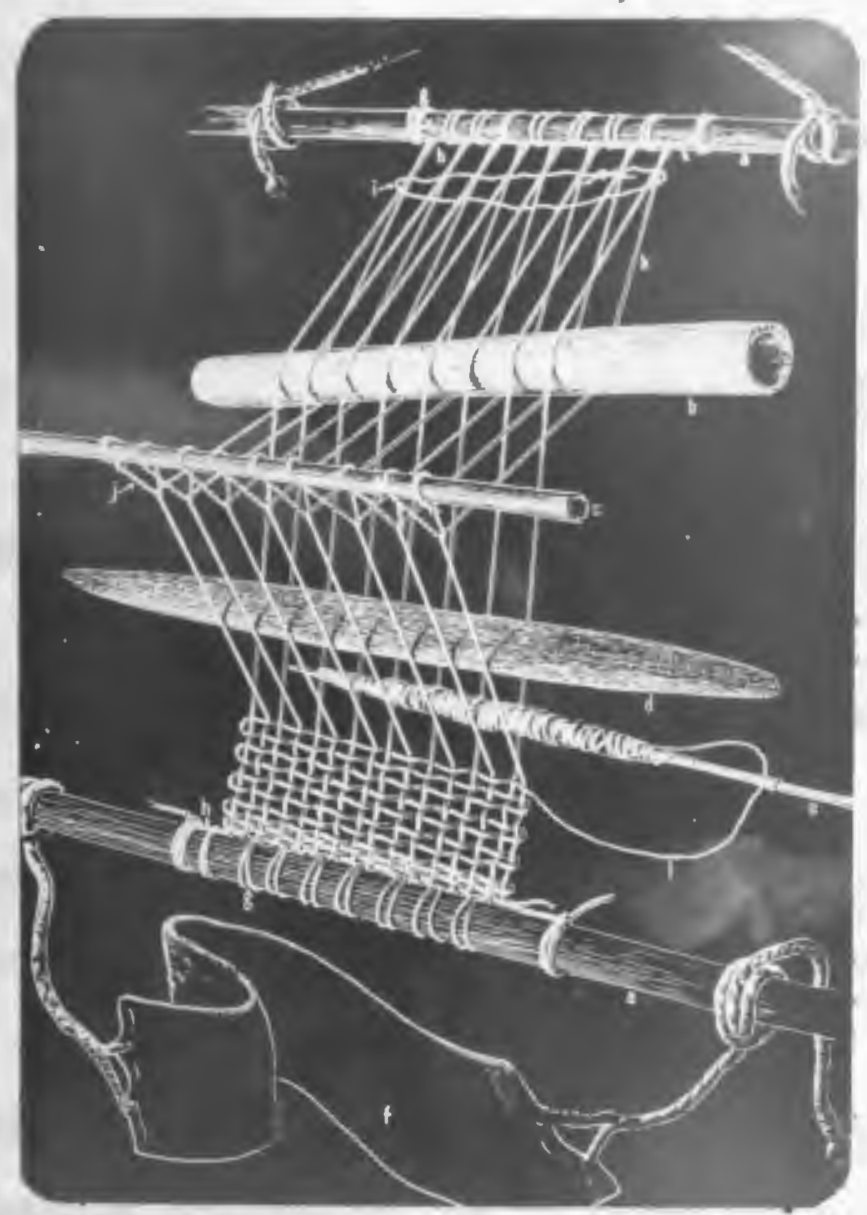

Figure 8. Diagrammatic representation of a backstrap loom. Source: Courtesy of the American Museum of Natural History, New York. 


\section{LIMITATIONS AND POTENTIALS OF THE LOOM}

BASED ON ITS STRUCTURE

Considering the technical features of the backstrap loom and the weaving with a continuous warp and string heddle set-up the following advantages seem to be obvious: 1. Low cost or no cost at all. Any sturdy wooden sticks could be used for loom bars. The implements that are inserted into the warp, however, do require a certain refinement or polishing. Pick-up sticks and shed-rods slide or roll better when smooth and the weaver's sword functions better when tapered at the two ends and along the broad side in order to fit the angle of the shed.

2. Iight weight. The number of required parts is very small. Five sticks constitute the basic loom.

3. Highly portable and movable. The loom is easily dismantled, rolled up and transported.

4. Close contact between weaver and material. The weaver is actually a part of the loom set-up. The close physical contact invites patience and helps create interest in experimenting and exploring with the material and the พeave.

5. Control over warp tension and differential warp take-up. Weaving procedures which normally are best woven with two warp beams, such as localized gauze, and limited shaping, could easily be woven with one warp bar. 
6. Extreme design potential. Pattern and weave possibilities other than plain weave should theoretically be unlimited. However, it would involve either the use of pattern sticks or pick-up sticks, or additional heddle rods including a one shed rod.

The backstrap loom can be easily expanded to a multi-harness loom and the sheds can rise and/or sink depending on the placement of the string heddles.

Plain weave requires two string heddle rods or one string heddle rod plus one shed rod. Although the string heddle rod and shed rod are equal in function, the shed opening effected by both varies. The height of the string heddle shed is based on the weaver's arm movement and body tension while, the height of the shed rod shed is always equal to the diameter of the shed rod. A round shed rod gradually but easily opens the shed by its rolling motion while a flat rod placed on edge forces the shed open and is negatively affected by yarn friction and high warp density. The string heddles have to be at least as long as the diameter of the shed rod in order to fall completely into the lower warp plane when the opposing warp yarns are raised.

The second basic weave, the twill weave, would require more than two warp divisions. A $2 / 2$ twill needs four wefts in succession. The warp control can be worked out in two ways: (1) with a straight twill threading and weaving by always lifting two heddles at a time, or 
(2) with a threading according to the weave draft and weaving by lifting one heddle at a time. Theoretically the heddle rod, analogous to harnesses on a foot powered loom could be lifted simultaneously to produce certain weave combinations, but in reality there are limitations. It is easier to raise only one or not more than two heddle rods at one time.

7. Unusual woven forms deviating from the rectilinear shape. The form would be determined by: (1) the shape of the loom bars and the sword or comb, or (2) shaping through the weaving process. Three possibilities exist: (a) through increased or decreased weft tension, (b) through different widths at the warp bars, and (c) through addition or subtraction of warp yarns.

8. Deflections of warp yarns to the right or left from the original vertical alignment.

9. Four finished selvages.

The limitations are few and are as follows:

1. Weaving with an even controlled cloth count. The spacing of warp yarns is initially established at the loom bars and can be regulated through the lashing of the warp yarns to the loom bars. Beyond this the parallel alignment of the warp yarns is only controllable through weft and warp tension and yarn properties. 
2. Maintaining an even fabric width. Actually this is an implication of (1) and can be regulated with a tenter. 3. Using a high number of string heddle rods efficiently.

The potentials are based on material requirements $(1,2,3)$, structure of the loom $(4,5,6)$, and the absence of the reed $(7,8,9)$, while the limitations derive mainly from the absence of the reed $(1,2)$. 


\title{
III. BACKGROUND INFORMATION ON THE PERUVIAN BACKSTRAP LOOM
}

\author{
PERUVIAN CULTURAL HISTORY
}

Geographically pre-Columbian Peru included the area of today's republic of Peru, parts of Ecuador, Bolivia, northern Chile and northwestern Argentina. Extending from just south of the equator to about $20^{\circ}$ southern latitude, it includes geographic extremes such as the high Andes range with high plateaus and peaks above 19,000 feet, the tropical jungle along the Amazon river and the narrow desert strip along the Pacific Ocean with its small river valleys which when irrigated supported large settlements in earlier times.

Although the habitable regions were of limited size and semi-isolated from each other, thus effecting the development of regional art styles and cultures, a general expanding population led to the spread of cults or expansion of empires which furthered inter-regional unification and rapid cultural changes. Three wide-spread pan-styles, Chavin, Tiahuanaco and Inca, with two intercessions of vigorous local styles are recognized. John $H$. Rowe suggested their chronological classification in periods and horizons, and based them on changes in pottery styles in the Inca valley on the south coast. 13 
Initial Period

Early Horizon

(Chavin style)

Early Intermediate

Middle Horizon

(Tiahuanaco style)

Late Intermediate Period

Late Horizon

(Inca style)
B.C. 1800

$1500-900$

B.C. $900-200$

B.C. $200-600$ A.D.

600 - 1000 A.D.

$1000-1476$ A.D.

$1476-1534$ A.D.

Information about the past is fundamentally based on archaeological findings since the Peruvians never developed any writing and the Spanish reports in the 16th century have to be understood in the context of the time period and with the backgrounds and affiliations of the writers in mind. Helpful to archaeology are the favorable climatic conditions on the south coast and the practiced burial customs which interned adult members of the society in cemeteries, carefully wrapped in clothes and supplied with elaborate grave goods, and children and destitutes with very little wrappings in refuse deposits. These cemeteries contributed invaluable information to the reconstruction of the cultures.

The archaeological activities began with the first systematic excavations under Ephrain George Squier at Pachacamac in 1864, continued with Max Uhle in 1896, and shifted from the reconstruction of the past to a concern to understand the complete cultural history in a soclological context with contributions from William D. Strong, Anna Gayton, Junius B. Bird, Julian Tello, and Wendell C. Bennett. ${ }^{14}$ Alfred Kroeber and Lila M. O'Neale collaborated by using art styles and textile techniques as time indicators. 15 
In 1937 came the foundation of the Institute of Andean Research, a joint venture of eight universities and scientific institutions with the annual publication of "Nawpa Pacha" 16 and from 1945 on archaeologists from many countries participated in the research.

Considering the study of textiles, several factors were responsible for a slower progress. There was the lack of: (1) interest on the part of archaeologists in favor of ceramics which naturally was a more durable and as such a more profitable medium, (2) textile training of archaeologists doing field work, (3) publications concerning textile finds and textile collections. Ina VanStan lists that:

...much that might be known of the treasures saved from the oblivian of Peruvian grave fields, is still buried in library and museum archives and storage rooms of Europe, Asia and both North and South America. A much greater quantity of wholly undocumented material remains in other collections, both institutional and private, and many of these in both categories, are inaccessible to students and research workers. 17

A further handicap is that earlier museum collections are primarily derived from the activities of the grave robbers, called huaqueros, and as such are without information about provenance and date. Although Peru recently passed a law to stop the digging and selling of archaeological material, the illegal activities still continue. ${ }^{18}$

A general summary of the cultural periods starts with the Pre-Ceramic Period between 2500-1800 B.C. When permanent settlements including towns and temples appeared on the 
coast between La Haldas and Asia (See Figure 9). With the absence of ceramic technology, and no evidence of irrigation or any luxury trade, the first textile manufacture started. Cotton and bast fibers were used, generally in two ply yarns. The materials from the excavation at Huaca Prieta proved that twining was the major practiced technique, with weaving playing a minor role. Since spindles and loom parts were not found among the finds, Junius B. Bird assumes that 2 frame loom must have been used. 19

The Initial Period, marked by the introduction of the heddle loom and pottery, saw the development of regional cultures. These had:

...the distributive systems, settlement types, political systems, social stratifications, and occupational specialization characteristic of civilization. 20

In the Early Horizon, about 900 B.C., a new religious cult appeared. Named after the temple in Chavin de Huantar in the central highlands, it spread fast, and within 100 years influenced the north and south coasts. The Chavin style, using visual metaphors, is mainly manifested in architecture and stone carving. Characteristics include:

...an intricate interweaving of mouth, eyes, snakes, geometric figures in stylized relationships to a ceptral human deity, animal or deity figure. 21

At that time metallurgy appeared and wool was used in coastal cities, indicating the existence of trade and commerce between the highlands and the coastal regions. 
The various cultures found a common economical and technological base, which remained even after the individual regions broke free and began to develop strong regional styles.

The Early Intermediate Period was characterized by socio-political changes. The coastal population grew to two million. There were trends towards urbanization on the south coast and in the highlands with new cities such as Tiahuanaco, Pucari and Huari, and towards dispersed communities and ceremonial centers in the north. Coastal societies experienced specialization and stratification. Population growth led to economic pressures and further to conquest and warfare. The archaeological records from this period are full of war topics. Above all, this period witnessed a high degree of art expression, especially in the Nazca and Moche cultures. The former is known for its exquisite embroidered textiles, especially those from the Paracas necropolis where Julian Tello discovered 429 mummies in 1929.22

During the Middle Horizon the Tiahuanaco style spread rapidly, appearing in its purest form in the area of Tiahuanaco in the southern Titicaca Basin. Recognized by the monumental structures and stone carvings, including the famous Gateway of the Sun which depicts the principal Tiahuanaca deity rlanked by rows of winged angels, 23 it is still unclear whether the style was connected to a religious cult or to 
a separate empire. It had relationships to the Huari or Wari empire which expanded through conquest and probably carried the Tiahuanaco style to the south and north coast as well as to the northern highlands. 24 The style changed in its travels to the distinct coast of Tiahuanaco variant. After not more than 100-200 years Huari, the capital, was abandoned and with it Tiahuanaco's influence waned. The urban cities in the southern highlands disappeared until 700 years later when Cuzco was built under the Incas.

The Late Intermediate Period between the HuariTiahuanaco era and the Incas, experienced the development of regional styles such as Chimu in the north, and Ica in the south. The population reached its maximum, with Chanchan being the largest city that was ever built in Peru. The period displays a high degree of technological competence in weaving, pottery and metallurgy. The emphasis was clearly on mass production and lacked the aesthetic qualities of the Early Intermediate Period. Regional differences in art styles became less pronounced, although they were still prevalent. Inter-regional commerce decreased but never disappeared from now on with textiles probably being traded more than pottery. From the end of the Late Intermediate Period scraps of historical evidence are avallable and archaeological records are used to verify them. 
During the Late Horizon in the 15th and 16th centuries, the small tribal state of the Incas grew into a rast empire with Cuzco as its capital until it fell to the Spaniards. The Incas excelled in governmental organization and manager ment. Relying on rural economy and strong centralization, life was strictly regimented and clothing symbols were attached to rank and professions. They ruled by military conquest enforced with diplomacy which led to a fast rate of integration but never to a point to supplant older styles. After Francisco Pizarro's conquest in 1532-38 Peru's history is connected with that of Europe and modern America. In 1821 Peru became independent after three centuries of Spanish rule.

Today, Peru is a republic whose leading party is committed to a retolutionary reform of the national structure. Three ethnic groups exist: the native Indians, the descendants of the Europeans, and the mixture of both, the mestizos. Although the official language is Spanish, the natives speak either Aymara or Quechua. The latter is actually the language which was spoken by the Incas, although the name refers to a tribe that was ruled by the Incas. 25 
PERUVIAN TEXTILES

As an entity, Peruvian textiles manifest the highly developed skills of craftsmen as spinners, dyers, weavers and embroiderers. The textiles, consisting of woven and non-woven fabrics plus specific ornamentations, display a wide range of textures which may vary from extremely fine to coarse, from lace-like to rug-like stmuctures. Used were a multitude of techniques which are best summarized in the permanent exhibition of Peruvian artifacts at the National Museum of Natural History, Smithsonian Institute, Washington, D.C. (Figure 10). The classification of the woven textiles contains: (1) plain weaves including tapestry, embroidery and dyed or painted cloth, (2) gauze, (3) patterned double cloth, (4) pattern weaves with supplementary warp or weft yarns, and (5) feather work. Of the three basic weaves, plain weave occurred most often, twill less and satin seemed to be missing completely. Although not true of earlier periods, the present day Peruvian textiles display almost exclusively the warp patterning techniques with a predominant high warp density. 26 Textile patterning seemed to have played an important role in the manufacture of woven and non-woven fabrics and the same designs were rendered in many techniques (F1gure 10).

The majority of the textiles served as clothing and had definite functional value. Junius B. Bird assumes that the percentage was 95 or higher. 27 The garments were woven 
to size, had four selvages and were finished on the loom. Men wore throughout the pre-Columbian history breech cloth and tunics, some kind of a headband or turban, a rectangular cloak or mantle and a bag to carry small items. The tunic was made of one or two loom widths with a slit in the center for the head and with the sides sewn up, just enough to have room for the arm openings. Women wore a long wraparound dress or long tunic which was tied at the waist with a belt. 28 The style of decoration, the sizes and proportions of the garments varied. Clothes played an important role in the social and ritual life at various periods and even designated rank and status. 29 since tailoring was unknown until the Spanish conquest, the garment shapes were based on rectangles and/or shaping during weaving. In addition, techniques were selected and combined for their structural value.

The earliest textiles were of cotton and bast, rather than of cotton and wool. Figure 11 shows the yarn distribution of 650 pieces from the coastal region dating from prehistoric to Inca times and examined by 0 Neale. 30

$$
\begin{gathered}
\text { Figure 11. Yarn Distribution of } \\
\text { Peruvian Textiles }
\end{gathered}
$$

\begin{tabular}{|c|c|c|c|c|}
\hline Period & $\begin{array}{c}\text { Pieces } \\
\text { No. }\end{array}$ & $\underset{\%}{\operatorname{cotton}}$ Only & Wool ${ }_{\%}$ Only & $\begin{array}{c}\text { Cotton and } \\
\text { Wool } \\
\%\end{array}$ \\
\hline Early & 167 & 41 & 33 & 26 \\
\hline Middle & 148 & 24 & 26 & 50 \\
\hline Late & 340 & 45 & 19 & 36 \\
\hline
\end{tabular}


According to $O^{\prime N e a l e ~ b o t h ~ c o t t o n ~ a n d ~ w o o l ~ w e r e ~ e m p l o y e d ~}$ throughout the periods. Cotton, belonging to the Gossypium barbadense species and considered the principal textile fiber of pre-Columbian Peru was cultivated in the coastal valleys and found in textiles as early as 2500 B.C. at Huata Prieta. 31 And today's Peruvian spinners are said to know six natuzally colored varieties of cotton "...ranging from light tan to reddish brown and gray." 32 Wool was early traded from the highlands and came from the cameloid family (alpaca, 1lama). Guanaco wool was only used in northern Chile and the textiles formerly classified as vicuna are now assumed to be of fine alpaca wool. 33 of the other fibers only human hair was used intermittently and then at rare instances. Silk and linen as well as metal threads are completely absent although gold and silver could be found in the form of small plaques for ornamentations.

Nowadays the spinning is done with distaff and whorl spindle where the spun yarn is wound in a cone on top of the whorl and then transferred to a shuttle for weaving (Figure 12), and where the spindle either hangs free for wool spinning or rests in a cup of pottery for cotton spinning.

Figure 12. Contemporary spinning tools:
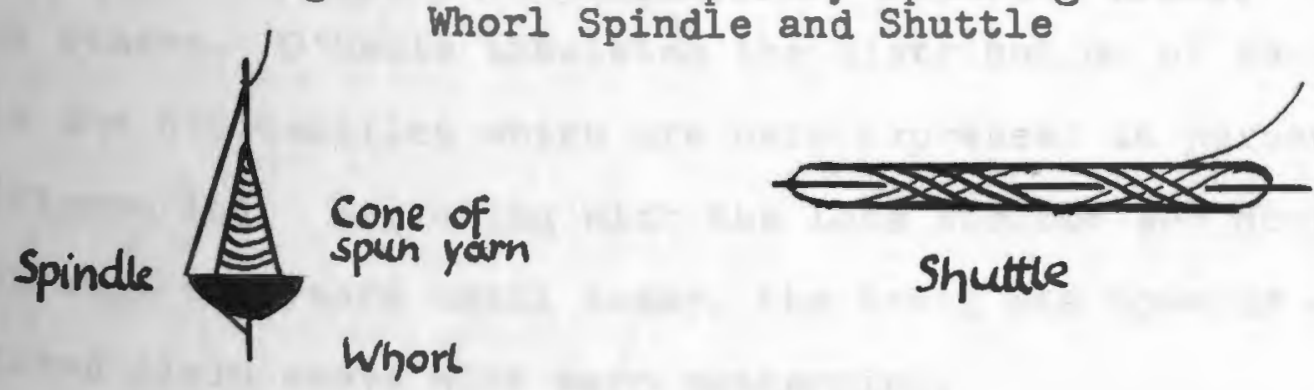

\section{Shuttle}


This spindle type is absent from archaeological material. Present were three types: (1) the banded spindle, (2) the tripart spindle--both serve as spinning and weaving tools-and (3) the double spindle which was used for doubling or plying two single yarns. The banded spindle ranged in length from the size of a large needle to 10" or 12", the tripart spindle was an extended spindle for wider weaving width, and the double spindle was longer and heavier 34 (Figure 13).

The yarns, mostly evenly and tightly twisted, were initially always plied ( $2 \mathrm{ply}, \mathrm{Z}$ and $\mathrm{S}$ plied) with a diameter of $0.5-0.7 \mathrm{~mm}$ in cotton and $1 \mathrm{~mm}$ in wool. Loosely spun yarns were rare, especially for cotton. Wool always seemed to be less tightly spun and plied. Crepe spins were rare but appeared frequently in later periods and creped singles were usually selected for sheer fabrics. 35

Many of the weaving techniques were already known in the pre-ceramic Period VI. Most of them were developed and in use during the Chavin period, particularly during the Paracas culture. 36 Once established, the number of techniques did not increase. There were only at times preferences for certain techniques sometimes even to the exclusion of others. O'Neale tabulated the distribution of techniques in the 650 textiles which are here expressed in percentages 37 (Figure 14). Beginning with the Late Horizon and continued through the years until today, the trend was towards warp faced plain weave with warp patterning. 
Figure 14. Distribution of Weaving Techniques

\begin{tabular}{|c|c|c|c|c|c|c|c|c|}
\hline 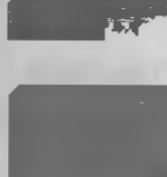 & Hess & $\underset{8}{\text { Gauze }}$ & $\begin{array}{l}\text { Bro- } \\
\text { cade } \\
\%\end{array}$ & $\begin{array}{l}\text { Pat- } \\
\text { tern } \\
\text { Weave } \\
\%\end{array}$ & $\begin{array}{l}\text { Double } \\
\text { Cloth } \\
\%\end{array}$ & $\begin{array}{c}\text { Tapes- } \\
\text { try } \\
\mathbb{\not}\end{array}$ & $\begin{array}{c}\text { Embroi- } \\
\text { dery } \\
\%\end{array}$ & $\begin{array}{c}\text { Knit } \\
\text { Stitch } \\
\text { \& }\end{array}$ \\
\hline Early & 167 & 1.8 & 1.8 & 7.2 & 0.6 & 7.2 & 18.5 & 19.2 \\
\hline Middle & 148 & 1.3 & 8.1 & 14.2 & 6.7 & 43.9 & 8.8 & 21 \\
\hline Late & 340 & 2.9 & 11.8 & 8.2 & 2.4 & 29.1 & 16.2 & 1.2 \\
\hline
\end{tabular}

Throughout the centuries the Peruvian design styles are visual expressions of the contemporary art style of each period. They also reflect the tastes and interests of craftsmen and consumers.

The limitations of loom, technique and material influenced the structural rendering of the various design motifs, forcing these into a more or less angular form due to the rectangular interlacing of warp and weft yarns opposed to applied designs such as embroidery and painting which offers full design freedom. Evident also is an interplay between technique and design elements when: (1) stylistic changes and borrowed motifs initially used in another medium demand the shift to a more suitable technique as seen in the choice of embroidery for the curvilinear naturalistic Nazca designs, and (2) a favorite technique continues and places its imprints on the new design style as seen in the tapestry technique, which was first introduced with the proliferous strain of the Nazca style to render the small projections and later continued to shape the extremely abstract designs of the Tiahuanaco shirts. 38 
In general the Peruvian textile designs adhere to a certain stability or tradition which is based on a strong conservatism of the people. This leads also to the refinement of skills, even to the point of perfection as well as to permutations of traditional elements. Commonly shared are motifs, design conventions, a technological base and materials. The motifs can be grouped into representational and geometric motifs. Although within each style period the motifs evolve from a more realistic to a conventionalized and then abstract representation, the representational motifs include mythical creatures, humans and animals, the geometric ones include diamonds, stepped triangles, frots. 39 The motifs are already present in the pre-ceramic period. In the Chavin, Nazca and Tiahuanaco periods supernatural or deity figures express religious concepts. In the Tiahuanaco period the deity figure is extremely abstracted and is featured as shattered elements of eyes, nose and bold teeth. The Nazca designs reflect socio-cultural influence when plant motifs and trophy heads appear together. When the emphasis is on mass production and more on skills than on aesthetics as during the Late Intermediate Period and Late Horizon, then small motifs became a practice. Beginning on corners and borders these small motifs finally covered the complete textile.

Certain design conventions regarding the organization or the composition of the design were early established and remained stable throughout the periods. Balance and symmetry 
were favored with the interlocking or reciprocal motifs of stylized birds and fish heads. Never demoted to monotony, the repetition used introduced rhythm through color alternations, bands and diagonal field arrangements as seen in the Paracas embroideries and again in the tapestries from the Tiahuanaco and Inca times. The Tiahuanaco shirts even feature a planned lateral distortion of the design units to aroid monotony which was imposed by sumptuary laws. 40 The Peruvian textiles use strong colors with the exception of the Tiahuanaco period when muted colors appear with red, yellow, black and white. In summary the Peruvian textiles are characterized by the use of perfect yarns, strong color schemes and common design motifs which were rendered in a multitude of techniques with each technique placing a certain imprint on the rendering of the design. The Peruvian craftsman as spinner, dyer and weaver exhibited extreme skills and knowledge of the media. He was able to combine design tools and materials successfully.

\section{ARCHAEOLOGICAL AND ETHNOLOGICAL PERUVIAN LOOMS}

Not much is written about the Peruvian loom. Usaally only mentioned in connection with textiles, it is described as the simple two-bar stick loom which existed in its present 
form already in Paracas Cavernas times and did not fundamentally change until today. O'Neal reiterates that the earliest known textile art of Peru was essentially as developed as any later one. 41

Today the Peruvian weavers use, next to the four harness and two harness treadle loom, introduced by the Spaniards, the two bar loom which is: (1) the backstrap loom when the loom is tied to the weaver's body and to a fixed object, (2) the horizontal loom when it is staked out on the ground with four pegs, and (3) the vertical loom when it is tied to a tree branch and to a rock on the ground (See Figure 15).

A vertical tapestry loom seems to have been in use during the 16th and 17th centuries. According to Poma de Ayaly the loom is supported by two posts and has one string heddle rod for weaving plain weave. But the necessary shed rod is missing in the drawing (See Figure 16). Only recently another representation of the tapestry loom has been found on top of one part of a polished double jar excavated at Pachacamac in 1958. Although dated Late Inca, it is not catablished if the loom is the product of Spanish influence or of Peruvian heritage. Ina Van Stan reports that three weavers can be recognized working on the loom. 42 
Contrary to this the looms or loom parts found at archaeological sites are two bar looms which are either lashed to an A frame or supplied with a backstrap, although It is presupposed that the staked out horizontal type was used as well.

Regarding the A frame loom, Schmidt reports that different sizes existed. Of the larger ones only parts are preserved. They consisted of two about $2 \mathrm{~m}$ long canes which were staked in the ground with one end and tied together at the other end. Figure 17 depicts a smaller frame of about $0.80 \mathrm{~m}$ length. Here the lower bar of the two bar loom is tied to the frame while the upper bar is connected to the tie between the frame, allowing for easy adjustment of the warp tension by lowering or raising this tie. 44

The silver toy from the Late Intermediate Period exhibited in the Peabody Museum, Harvard University, probably is a replica of such an A frame loom which in its depicted set-up could easily be used as a support for scaffold wefts (see Figure 18).

Regarding the two bar loom used as a backstrap loom, numerous specimen exist. In addition most of the ancient fabrics are within 30" width, just within the arm reach of the weaver. Therefore it is "generally agreed that most of the excavated woven fabrics were constructed on backstrap looms. $n 45$ 
Literary information about the Peruvian backstrap

loom derive from: (1) literary accounts or folklore,

(2) representation on pottery or other art media, and

(3) remains or intact assembled looms with unfinished textiles.

\section{Literary Accounts}

Regarding the contemporary use of the loom, some of the Highland Indians weave narrow belts in twill weave on a multi-heddle loom. No more than three heddle rods plus one forked shed rod are used (see Figures 19, 20). Larger weavings with more than four warp divisions are handled adeptly with pattern sticks plus the plain weave set-up.

Regarding archaeological looms the literary evidence can only start with the time of the Spanish conquest. Felipe Guaman Poma de Ayala when depicting the life in Peru in the Codex Peruvian includes an illustration of a woman weaving on a backstrap loom (see Figure 21). The weaver works in kneeling position on a loom which is equipped with a shed stick, one heddle rod with string heddles. Four long sticks, pointed at both ends, are inserted into the warp. The caption reads "Inca weaving. Mochica type loom for weaving warp-face cloth. ${ }^{46}$ Presumably the sticks are pattern sticks. No woven web on the cloth bar or woven heading at the warp bar are indicated. 


\section{Representation on Pottery}

In the British Museum is a vessel from a Chicama Valley grave side from the Moche period. The scenes on the 3" flared rim depict women weaving on backstrap looms. 47 Here the woman weaver kneels and sits back during the weaving. The upper bar of the loom is attached either to a house post or a forked upright post. The slant of the warp plane is steeper than in the Spanish drawing. Tapestries are woven on all eight backstrap looms, as indicated by the woven but unfinished design on the looms, the many bobbins which have yarns on them, and the cartoon or sample piece next to the loom. The number of looms and the presence of a supervisor next to the weaver seem to indicate an illustration of a weaving workshop (see Figure 22).

\section{Description of Extant Archaeological Looms}

The earliest loom with string heddles seems to be the Paracas Loom, Specimen 8465a in the National Museum, Lima, Peru. According to O'Neale the warp measures 25 " $\times 3$ ". Seven inches are woven and one row of string heddle loops is about 5" from the woven web. Cotton yarn is used in warp and weft. 48

Joyce describes a loom with an unfinished double cloth of the Chimu Period from the burial gounds in the Departments of Lambayeque, La Libertad and Ancachs. It has two heddle rods and "one of the two presumable shed rods in position ${ }^{49}$ (see Figure 23). 
Roth writes about an ancient Peruvian loom with 12 pattern sticks interlaced in the warp, and one string heddle cord (three pieces of cord hold the continuous string

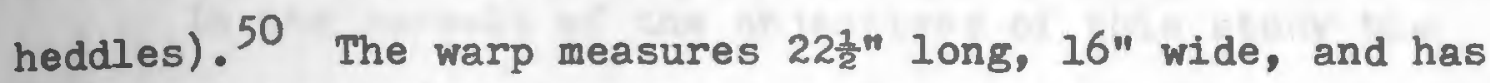
a cloth count of $19 \times 144$ in the plain web, and $19 \times 93$ in the patterned web. According to Roth weaving with pattern sticks is still practiced in Africa. Each pattern requires a different arrangement of the pattern sticks. Each pattern stick forms the shed for one weft. After its use, the stick is withdrawn and immediately reinserted into the warp after the previously used pattern sticks. Unfortunately the loom, at one time listed as specimen of the Manchester Museum, England, could not be located recentiy 51 (see Figure 24). 


\section{METHODS}

In the pursuit of the objectives of this study the following was undertaken:

1. A questionnaire on the Peruvian backstrap loom and the fabrics woven on this loom was sent to 174 museums, and personal inquiries were addressed to 8 resource persons for possible leads to further information, in February 1974. A follow-up letter followed in May 1974, and in January 1975 an inquiry about possible double cloth loom specimens were sent to 11 museums which had answered positively in the first inquiry about the loom (see Appendix D).

2. The 11 museums in the New England Area, in New York City and Washington, D.C., which indicated the possession of Peruvian textile and loom collections, were visited once or as needed (see Appendix E).

3. Actual weaving experiments with the backstrap loom led to a better understanding of the inherent limitations and potentials of the loom. The experiments dealt with the absence of the reed and the complexity or practicality of the heddle system. Also, the findings are explored with regard to possible applications for contemporary handweaving.

There were several implications and difficulties connected with the questionnaire and the actual museum visits. Although the names of the museums were taken from the Official Museum Directory (1973) 52 published by the American Association 
of Museums and only selected if the museum listed collections which pertained to archaeology, pre-Columbian, South American, American Indian and Peruvian artifacts, the entry information was supplied by the individual museum and reflected more or less the relative value of the collection to the museum. In other words the entries were not standardized. The format of the museum visits depended also mainly on the policies of the museum. Therefore the accessibility of the collection to the student researcher varied greatly. In most cases the visits consisted of personal interviews, reviewing the permanent or specific exhibitions, searching through the photographic files and researching specific specimens which were supplied by the museum personnel. Actually the latter was a necessity since museums catalog by acquisitions and have no cross reference for subjects.

The questionnaire consisted of two parts, one assessing the loom and the unfinished textile on the loom, and the other referring to textiles woven in specific techniques which could indicate limitations and potentials based on the operation of the loom.

The museums fell into three categories, of which 46 percent were art museums, 41 percent historical museums and 13 percent specialized museums. Ninety-five percent of the museums were located in the United States, and 5 percent in Peru and Europe (West Germany and England). 
The returns on the questionnaire and follow-up letter were 91 percent. The question about the backstrap loom was mostly answered while the one concerning the Peruvian fabrics was ignored or treated vaguely, mainly due to the detailed format of the questionnaire. Thirteen percent of the museums had one or a few looms, including 5 double cloth looms, 80 percent had no weaving equipment and 7 percent did not reply. Regarding Peruvian fabrics, 42 percent indicated that they were in the possession of fabrics, 34 percent answered no and 23 percent did not reply.

Several leads to literature and resource persons were offered. They all pointed to Dr. Junius B. Bird, American Museum of Natural History, New York, who is an acknowledged authority on Peruvian textile archaeology and to the Bankield Museum in Halifax, England. Thanks to Dr. Junius B. Bird, the American Museum of Natural History has the best collection of South American backstrap looms in the United States. The looms are well-cared for, restored, well-documented, and ready for publication. 53 The collection contains 189 looms, of which 61 are archaeological specimens. The largest loom sample comes from Chancay, numbering 23 with 3 samples from the vicinity of Lima. Three looms date from the Middle Horizon, all others stem from the Late Intermediate Period. 54 The recognition that the Peruvian looms are worth sellecting and that the unfinished textiles could be used in explaining developments in textile techniques is not commonly 
shared among archaeologists associated with museums. Moreover the lack of textile expertise on the part of all those who handle archaeological material from the excavation site to the museum often causes confusion. Loose sticks in the warp are often lost which could have been indicative of the weaving technique. Wrong weaving implements are often added during the process of reconstruction, and the wide-spread unfamiliarity with textile terms can lead to mislabeling of specimens. Figure 25 was labeled a double cloth loom, but is actually a loom with a textile woven with supplementary warp patterning. 


\section{RESULTS AND DISCUSSION OF LITERARY RESEARCH, KUSEUM VISITS AND EXPERINENIAL WEAVING}

\section{DEVELOPMENT OF THE BACKSTRAP LOOM}

The backstrap loom stayed basically the same simple loom since its first use. The parts derive from local material, were in earlier times and could be today of cane, cattail stalks or just twigs or branches. Therefore identical looms are almost unknwon, although regional differences do exist in the warp set-up, the heddle lacing and weaving techniques.

Regarding evolutionary changes in the shape of the loom parts to improve their function in the weaving process, the shape of the loom bar changed from broken off cane rods or round sticks to flat notched wooden slats in modern looms which secure the heading cord in a simple manner (Figure 26). In the case of a long warp where the winding up of the woven web is important, the cloth bar and the auxiliary bar can be combined to a wooden bar with a center cut-out (Figure 19).

Regarding evolutionary changes in the heddle system to allow for weaving of double cloth and twill, the evidence has to come from completely undisturbed intact looms with the specific textile still on the loom since the weaves can be woven by various methods. This requirement is hard to 

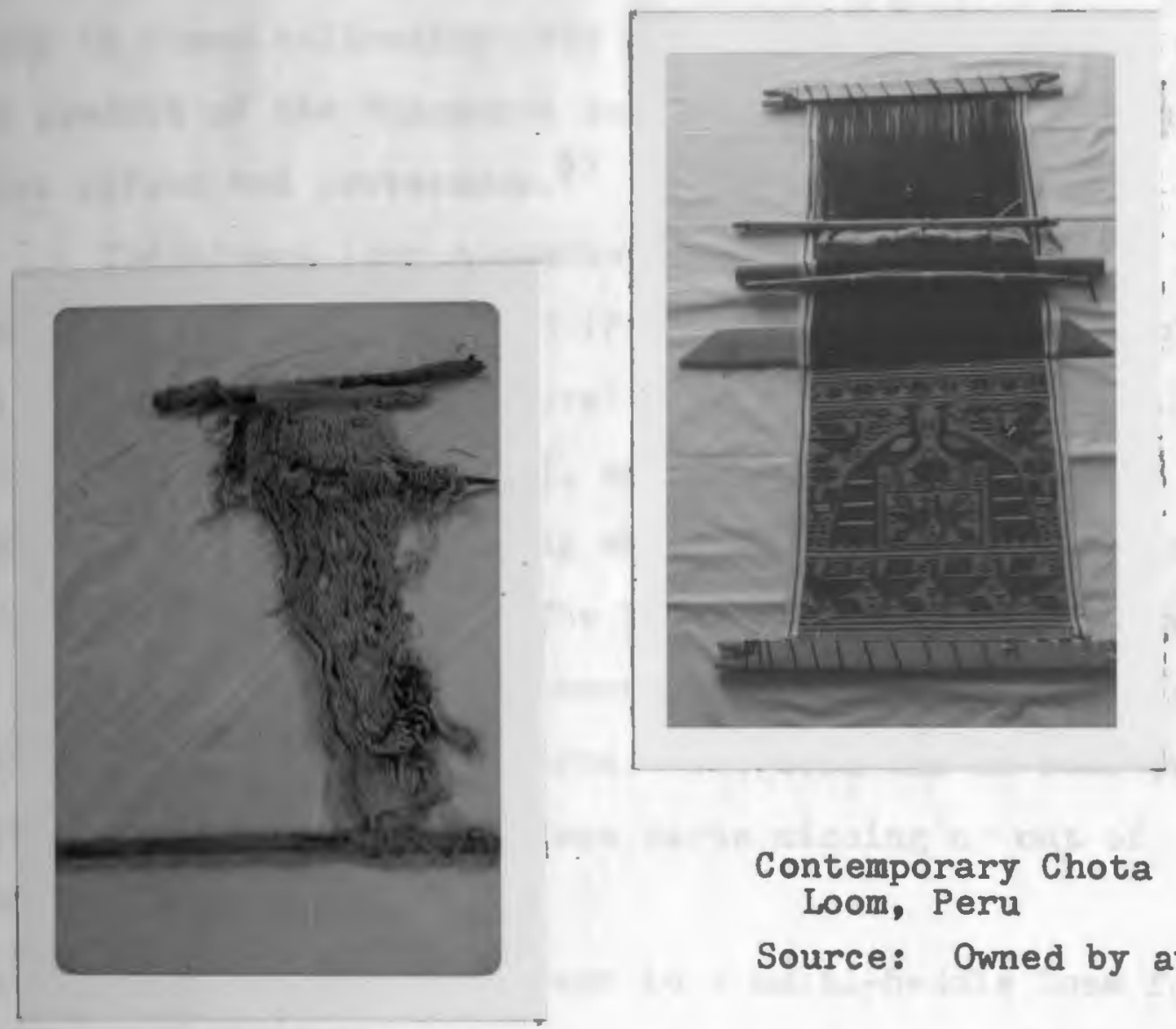

Contemporary Chota Loom, Peru

Source: Owned by author.

Archaeological Reed Loom - From Huacho

Source: \#307602, National Museum of Natural History, Smithsonian Institute, Washington, D.C.

Figure 26. Old and Present Day Shape of Loom Bar. 
fulfill since except for archaeological looms most of the looms in known collections are less than 100 years old, are the product of the Huaqueros and are without information about period and provenance. 55

The oldest loom encountered in this research has 3 heddle rods and one shed rod (Figure 27) (accession \#19638-1, American Museum of Natural History). The loom is dated from Middle Horizon II, and depicts a fabric in supplementary weft patterning which was the most frequent technique at that time. ${ }^{56}$ The basic weft of cotton is woven in plain weave ( $1 / 1$ interlacement) while the woolen pattern weft is woven over paired warps. The loom was in near perfect condition without any loom parts missing or out of place.

There is the development to a multi-heddle loom for weaving double cloth, but nothing is known about when it came into use. The double cloth loom (catalog \#B-7771, American Museum of Natural History) (Figures 28, 29) is without positive proof since it has been restored in part after a photograph at the time of acquisition in 1901, and in part after the weaving analysis of double cloth, and is without date. 57 Contemporary double cloth looms from Mexico use three heddle rods and one shed rod, and the commissioned contemporary loom by. Truman Bailey has even a counter heddle on the underside of the warp 58 (Figure 30 ). 


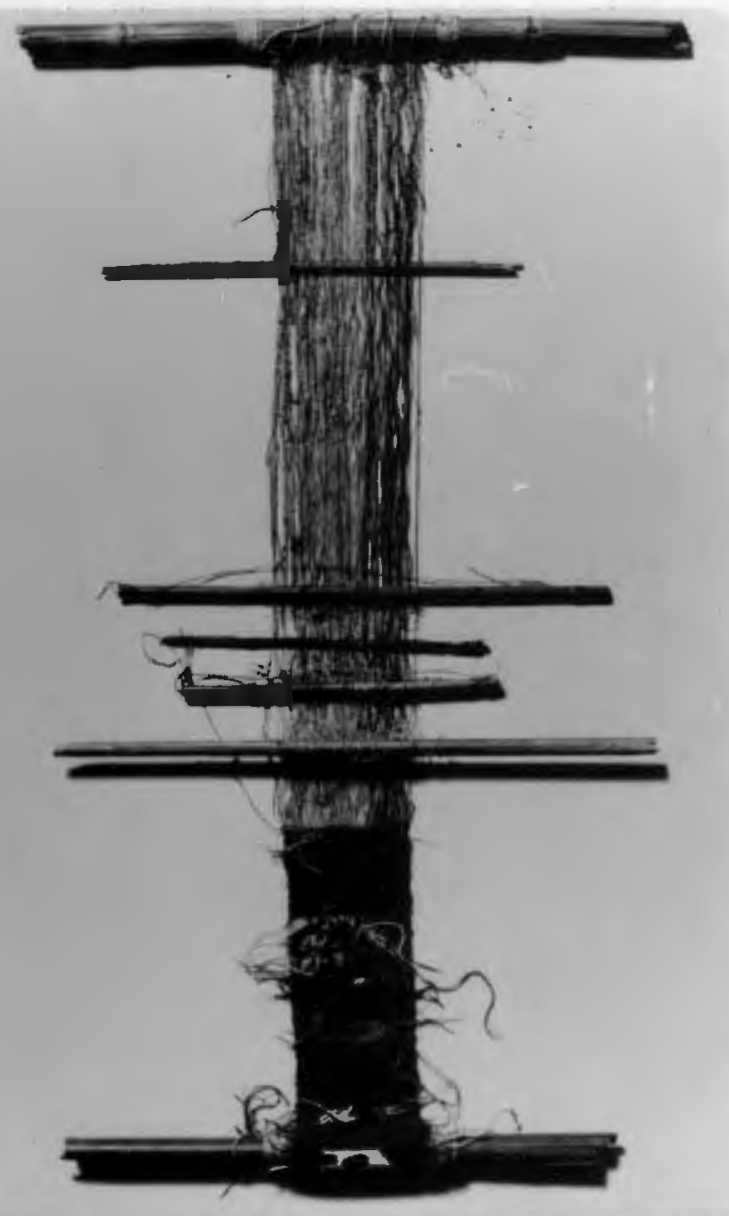

Figure 27. Archaeological loom found in near perfect condition.

Source: (Neg. 329712 , accession \#1963-8-1). Courtesy of the American Museum of Natural History. Note: Loom dated from Middle Horizon II with unfinished textiles. 


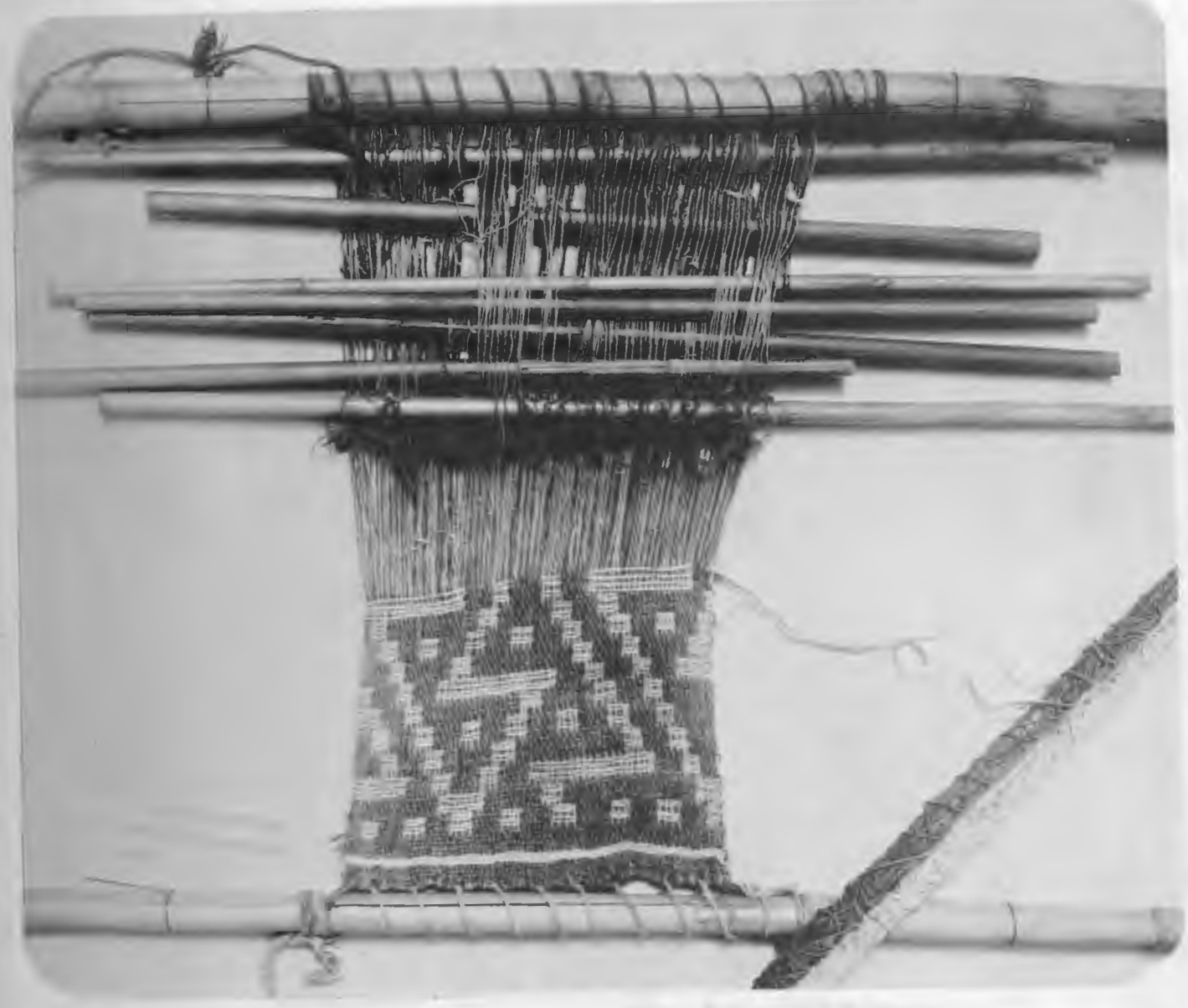

Figure 28. Double Cloth Loom (multi-heddle loom). \#B-7771 at time of acquisition. 


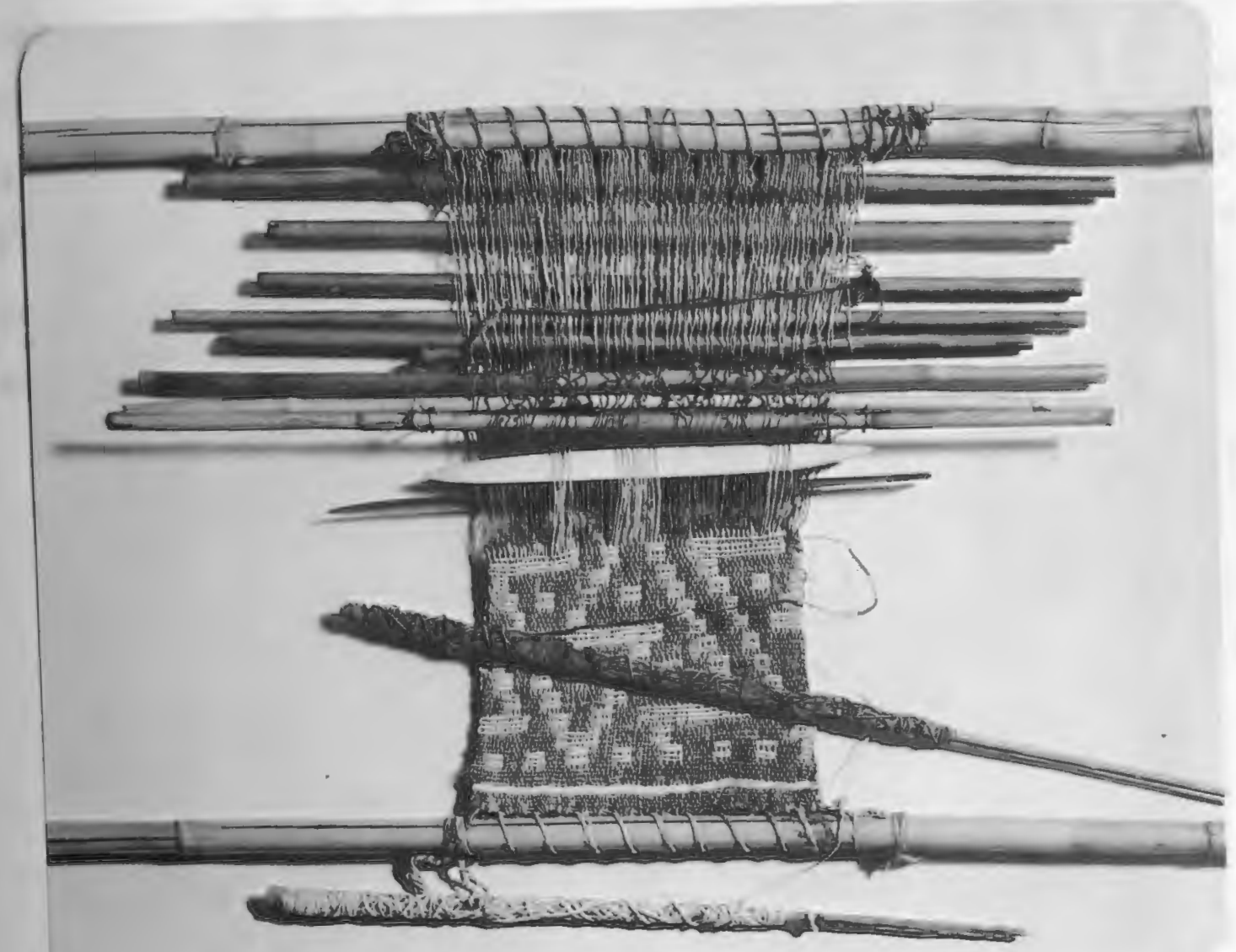

Tigure 29. Double Cloth Loom (multi-heddle loom).
Print taken from Curator, Vol. 7, No. 2, Print taken f $\# B-7771$ restored 
There is no evidence available that the Peruvian loom used twin heddles, or that the string heddle rods were changed into harness frames and treadles, which Roth recognizes as the ultimate steps in the developments of a simple loom. 59 In addition the Peruvian loom did not adopt a flat shed rod wich Roth labels as improvement over the round stick. 60 The researcher disagrees with Roth since the clearing action of the round stick is better for a warp-faced fabric than a flat stick. Therefore, the shape of the shed rod should be considered as a solution to a particular problem and not a derelopmental stage.

Figure 30. Present-day double cloth looms.

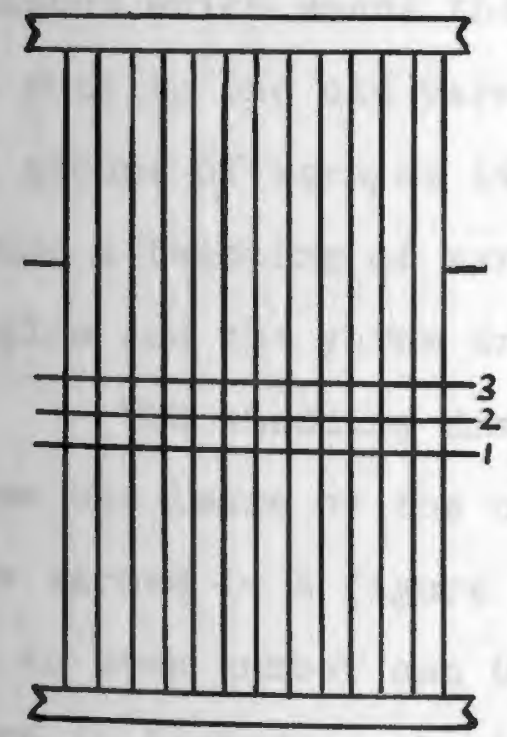

Mexico
Shed rod

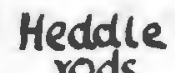
rods

\section{Double Cloth Loms}

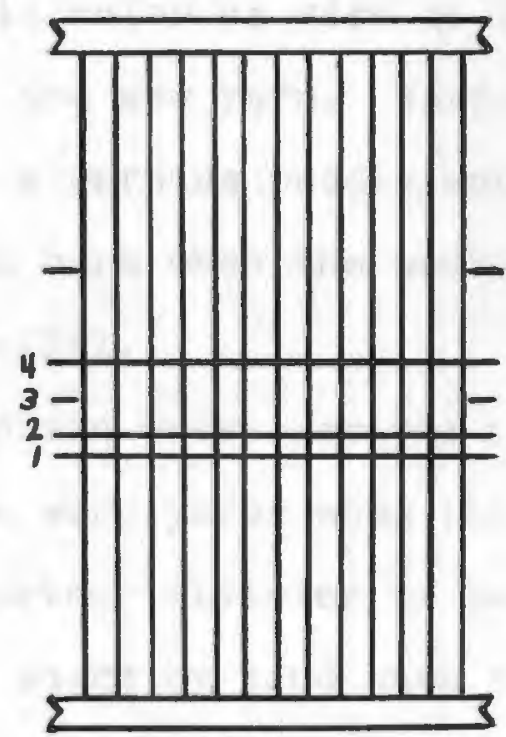

Truman Bailey 
POTENTIALS AND LIMITATIONS OF THE BACKSTRAP LOOM

The limitations and potentials of the loom specifically refer to the loom set-up, the absence of the reed and the complexity of the heddle system. They have to be recognized on unfinished textiles attached to loom specimens, may be supported by finished textiles, but have to be verified through actual weaving.

\section{Loom Set-Up}

Warping

When working with a continuous warp and string heddles, the preparation of the warp (the warping procedure) becomes important. The simplest way would be to use one yarn continuous which means that any change in color or yarn is done by cutting the old yarn and tying on the new yarn. Warping in groups of yarn, as it is done with a warping paddle, would cause a twisting of yarns at the loom bars when the weaving begins and the yarns are aligned parallel.

The shedding division of the plain weave derives simply from the lease or the crossing of the warp yarns when they are warped in a figure eight. Any further division if based on an even number can be worked from there by hand when the warp is lashed to the loom bars or can be built into the warping procedure. More difficult are the warp divisions based on an odd number and without straight succession of the wefts. These can only be counted out yarn by yarn on the stretched warp. 
No one really knows how the Peruvians solved this procedure. Information of today's Indian weaving points to the use of a horizontal pegged warping board where the upright pegs could easily double for loom bars later on. Figure 31 with the caption "Setting warp on loom" illustrates the warping procedure which is practiced in Guatemala by the Zutugil Indians. O'Neale mentions various warping methods of Guatemala where single or double figure eights are used (Figure 32). By removing the center pegs, the final warp figuration is either a single figure 8 ( 1 , and 3) or a plain ring warp (2).

Single figure 8 with 2 pegs (1)

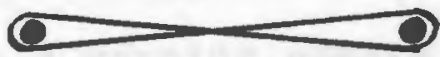

Double figure 8 with 3 pegs (2)

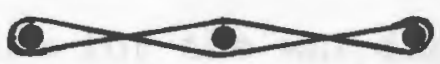

Double figure 8 with 4 pegs (3)

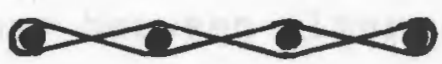

Figure 32. Warping techniques, Guatemala.

The methods for making partial warp divisions are illustrated by 0 'Neale in the preparation of the warp for plain and tie-dyed yarns where the patterned yarns are laid over separate pegs "to keep track more easily of yarns," 61 and by Redwood who uses the same method for making warp divisions for individual heddle rods. 62 Here the warp yarns are divided in half by the cross, and then one half is subdivided again by alternately skipping one peg in each turn. 
Schmidt in "Kunst and Kultur von Peru" features a warp set up of a loom from Pachacamac which seems to have the figure eight figuration (Figure 33), while the warp set up of the small interlocked warp in the Peabody Museum, Harvard University is done in a ring form (Figure 49). The modern Chota loom has the warp yarns grouped in bundles of 14 yarns which actually points to the use of a warping paddle (Figure 38). Strangely enough the Cranbrook Institute of Science, Bloomfield, Michigan has a slot and eye heddle with a handle which is labeled "Weaving frame, wood, form of a grid iron found in prehistoric Peruvian tombs (6 $6 \frac{1}{4} x$ 3", \#4797) (B-2790) (Figure 34). The handle suggests that this piece is not part of a loom but more a warping paddle which, in this particular case, would allow for the warping of 19 warp ends simultaneously with a cross between alternating yarns.

All this information suggests that there are several warping procedures which work with staked out pegs and produce either a figure eight or ring warp figuration. But there are no indications that complicated warp divisions as required for the weaving of various twills have been prepared by the Peruvian weaver on or carried out on the warping board. 


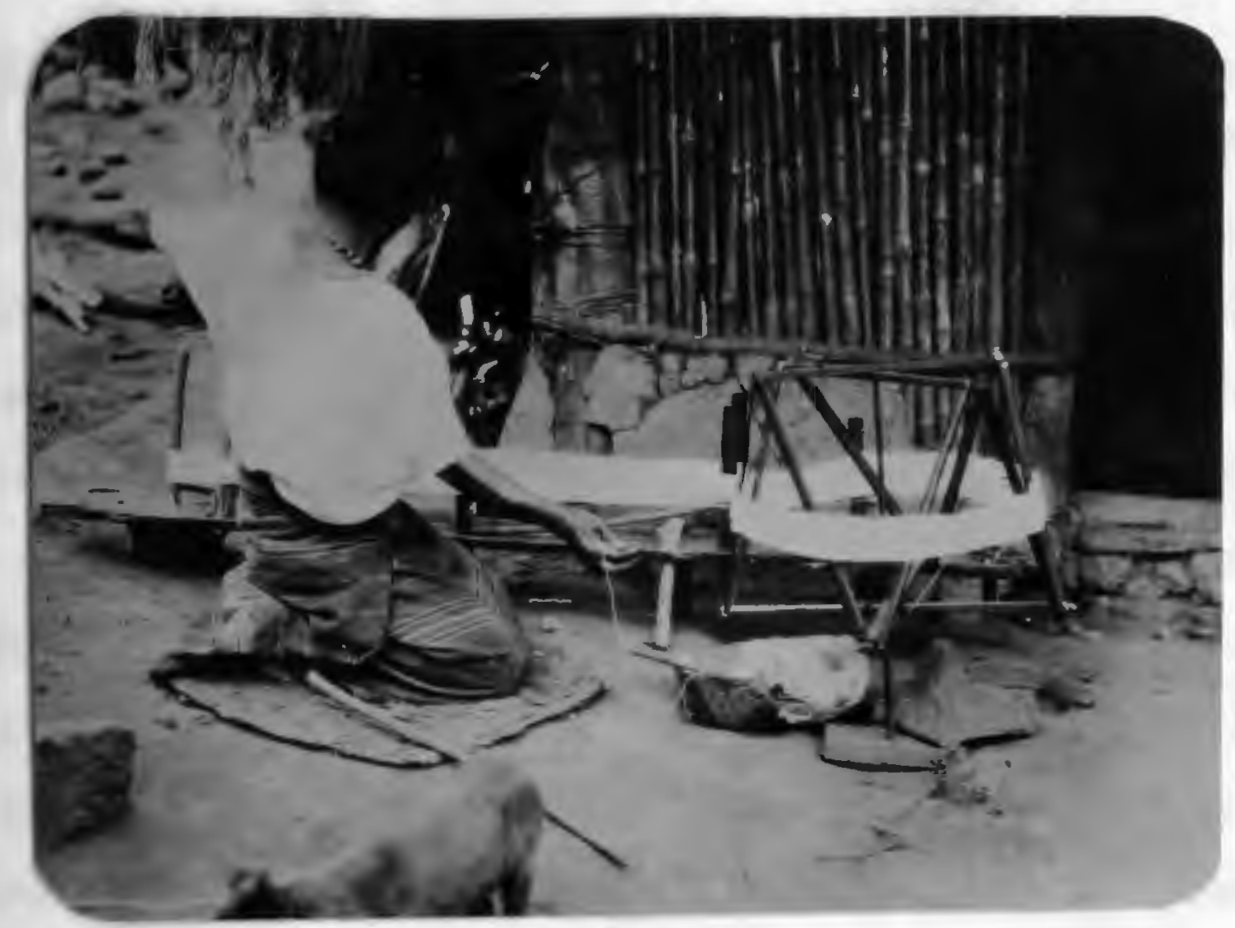

Figure 31. Preparation of warp on a warping board.

Source: Photograph Courtesy of the American Indian, Heye Foundation. Zutugil Indian, San Juan Laguna, Guatemala.
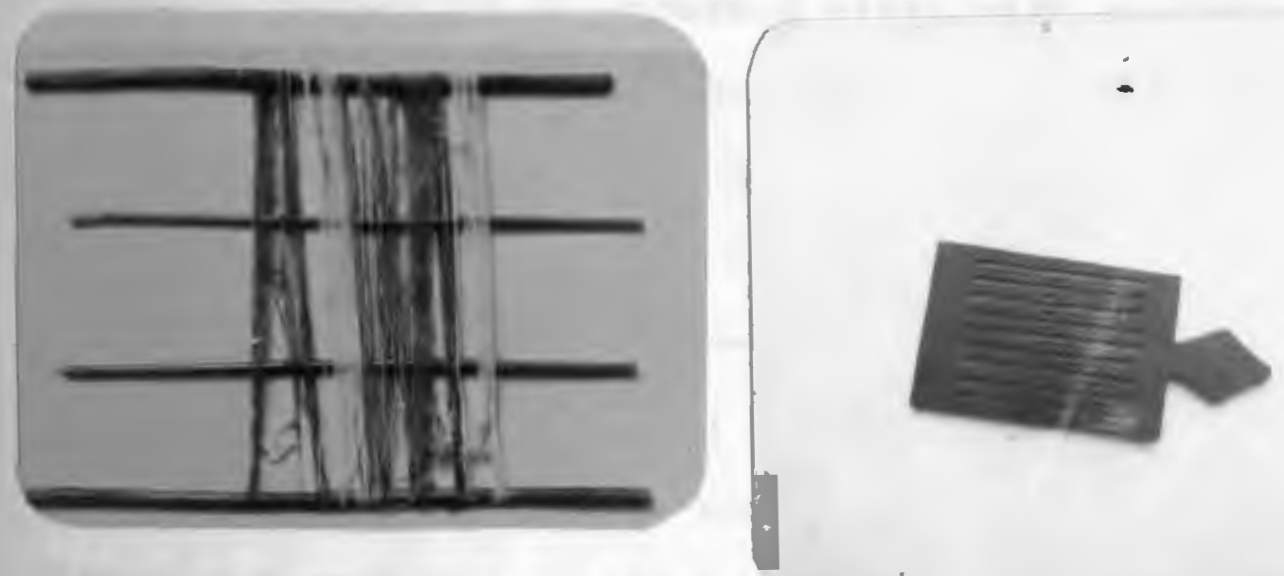

Figure 33. Warp set-up,

Pachacamac.

Source: Kunst and Kultur von Peru, Max Schmidt, No. 521 .
Figure 34. Warping paddle. Source: Cranbrook Institute of Science, Bloomfield, Michigan. Note: No. $4797(\mathrm{~B}-2790)$ 
Meaving Width and Length

The length of the loom bars and in particular the arm span of the weaver are the limiting factors for the woven width of the backstrap loom textile as is the thickness of the woven cloth rolled around the loom bar which rests in the weaver's lap for the duration of the weaving.

Most backstrap loom weavings fall within $30 "$ widths. 0'Neale reports that the great majority of the Peruvian textiles have individual weaving widths from 12-26". 63 Larger unseamed textiles do exist, but the closer examination done by O'Neale as well as King found that they could have been joined by an extra warp yarn in a dovetail manner involving either single or groups of wefts after the fabrics were removed from the loom. 64,65

But $0^{\prime}$ Neale reports that two of the Cahuachi Nazca fragments belong to an unseamed cloth with a width of 5'5".66 Bird mentions Paracas specimen with widths up to $17^{\prime} 8^{\prime \prime}$ and lengths of $87^{\prime}, 67$ and $0^{\prime N e a l e ~ w r i t e s ~ a b o u t ~ o t h e r s ~}$ measuring $7^{\prime} 7^{\prime \prime}$ and $8^{\prime} 3^{\prime \prime} .68^{\circ}$ She assumes that the weaving probably was done on a large-size frame loom or with a "weaving procedure involving several persons seated side by side."69 Truman Bailey commissioned once a loom "from directions supplied to him by one of his weavers who had seen or heard of such a loom from her mother."70 As seen in Figure 35, the loom has one huge loom bar, one heddle rod and one shed rod. It is not possible to recognize if 
there is one backstrap for the three weavers or three backstraps, one for each weaver. The latter would allow for better tension control. Also, unclear, is how the shuttle or bobbin was passed through the open shed. Presumably it was thrown rather than passed through similar to a fly shuttle.

The length is also restricted, although to a lesser degree than the width. 0 'Neale reports of Paracas garments four yards long and up to 46 inches wide, and refers to Carrion Cachot who speaks of two wrappings from bundles 157 and 290 that they were $20.70 \mathrm{~m}$ long and $4.89 \mathrm{~m}$ wide. ${ }^{71}$ A Peabody Museum report mentions a textile $47^{\prime}$ long and 12 wide. 72

This study encountered only one loom with loom bars of 48 inches in length, but with a fabric width of 30 inches (Specimen \#154, Haffenreffer Museum, Brown University) and one large textile (\#41,1/5403, American Museum of Natural History) which is a shaped shirt. It measures 84 inches across the shoulders and 38 inches across bottom. The former illustrates that the arm span of the weaver is the deciding factor in the fabric width. The latter has to be woven on a two bar loom with a string heddle system, but not necessarily on one with a backstrap. 
In summary, the weaving on a backstrap loom is definitely restricted to a certain width and length depending on the build of the weaver. Odd pieces could be produced as in the illustration of the loom for three weavers but it is unlikely that this was a common practice. Also the suggestion that the Peruvians wove large pieces as triple width or quadruple width fabrics seems very unlikely in light of the structural features of the backstrap loom and the required heddle rods or warp divisions for weaving triple or quadruple cloth. 73

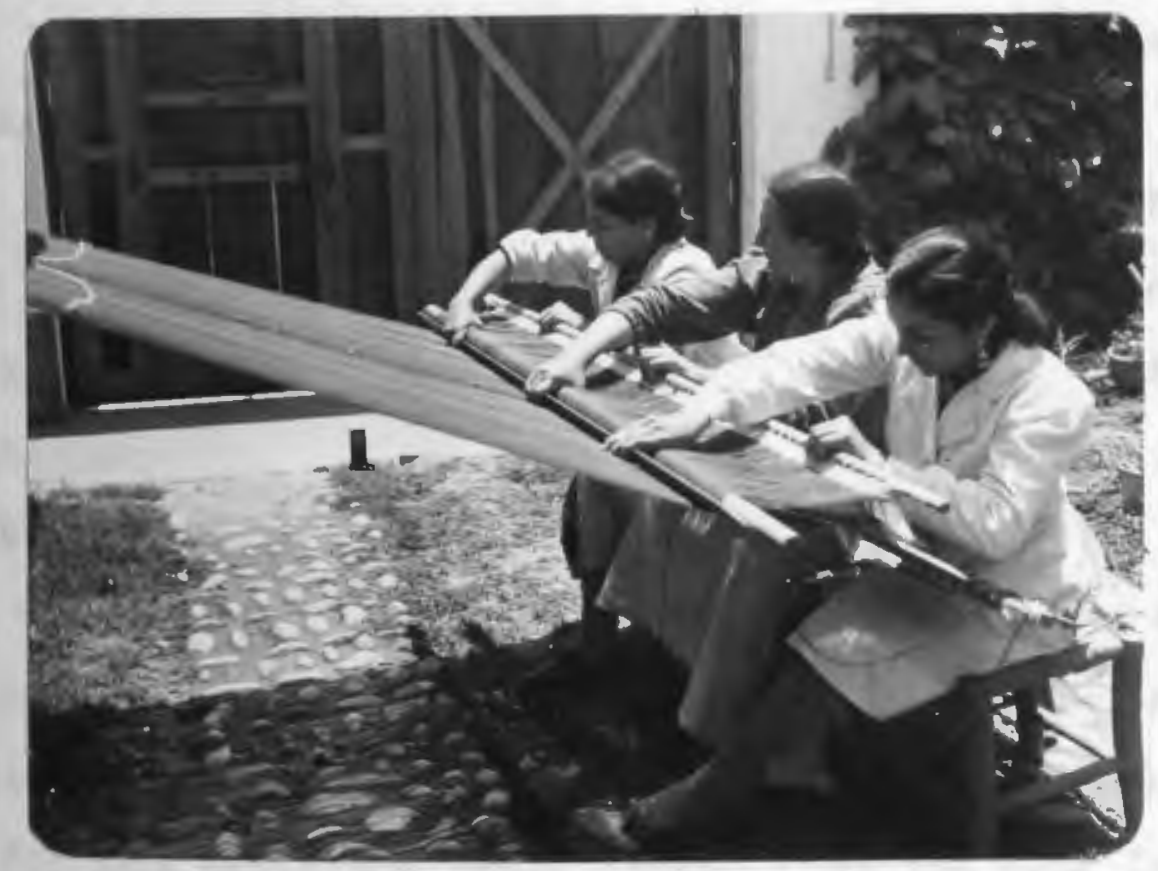

Pigure 35. Wide backstrap loom. Source: Courtesy of the American Museum of Natural History, New York. Reproduced 2 A 354. 
Attachment of Warp

to Loom Bars

In order to establish the tension on a continuous warp which is woven with four selvages, the warp loops have to be secured by either a rod, or a heading cord, usually of heavier yarn which is tied to the loom bars after one, two, or three picks (wefts), or a regular weft which is not tied to the loom bars. All three have to be lashed to the loom bars in regular spaced intervals of which the spiral lashing is the most common form. The more vertical the spirals the closer are the intervals and the greater is the control over the spacing of the warp yarns. But only a half hitch lashing can provide perfect spacing without relying on additional weft interaction.

Figure 36 lists the various methods of attachment as found in illustrations by Roth, and in museum specimens. Bird and Bellinger report three-pick heading cords for the Paracas specimen. 73 Skinner notes that the only three looms in the collection of the American Museum of Natural History which date from the Middle Horizon plus one from Pachacamas have a two-pick heading cord while all other looms have a one-pick heading cord. 74 Eisleb reports a three-pick heading cord for the patterned twill fabric from the Late Intermediate Period. 75 Contemporary looms have usually a one-pick heading cord except when two wefts are required to realign grouped yarns into single yarns as in the Chota loom (Figure 37). 


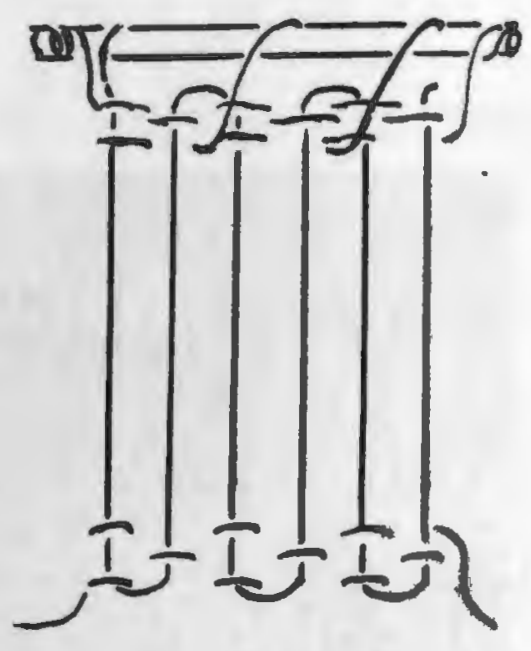

Diagram of a Paracas continuous warp with heading cords. From: Bird, J. Paracas Fabrics and Nazca Needlework, 195,4 , p. 93 .
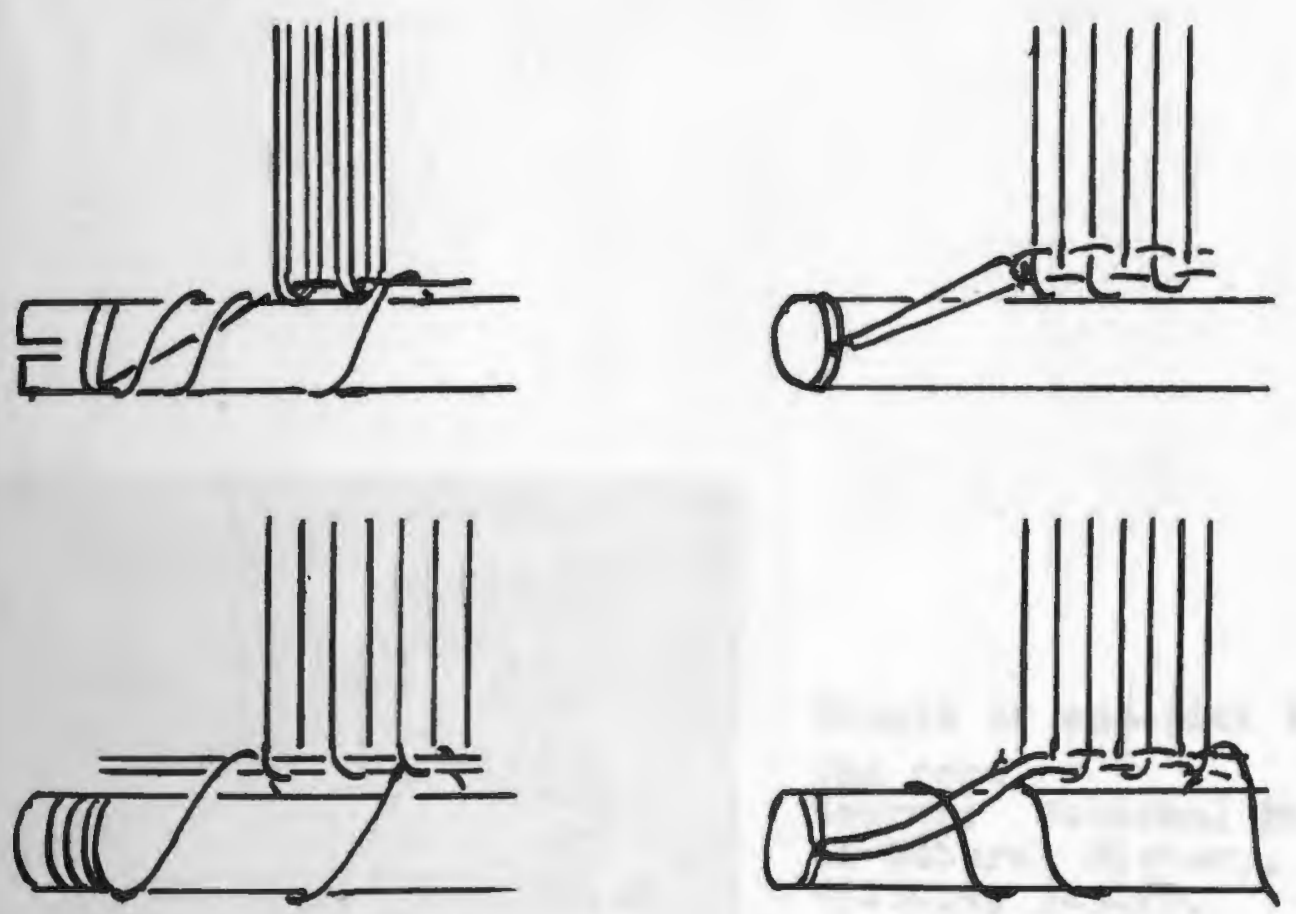

Various methods of inserting the heading cords.

From: Roth, H. L. Studies in Primitive Looms, Man, Vol. 46, 1916 , p. 307.

Figure 36. Methods of Attaching the Continuous Warp to Loom Bars. 


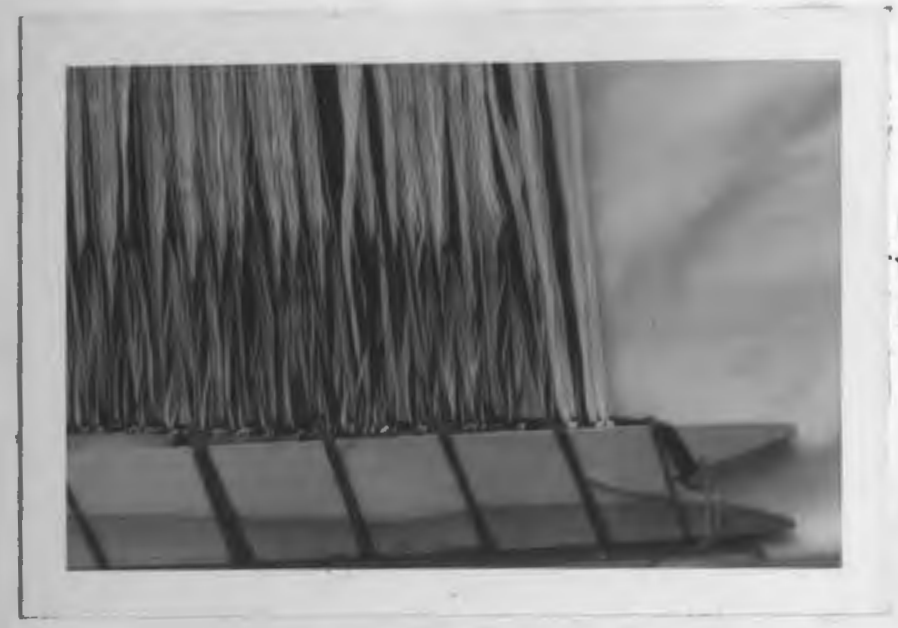

Chota loow, warp is warped in groups, two pick heading cord

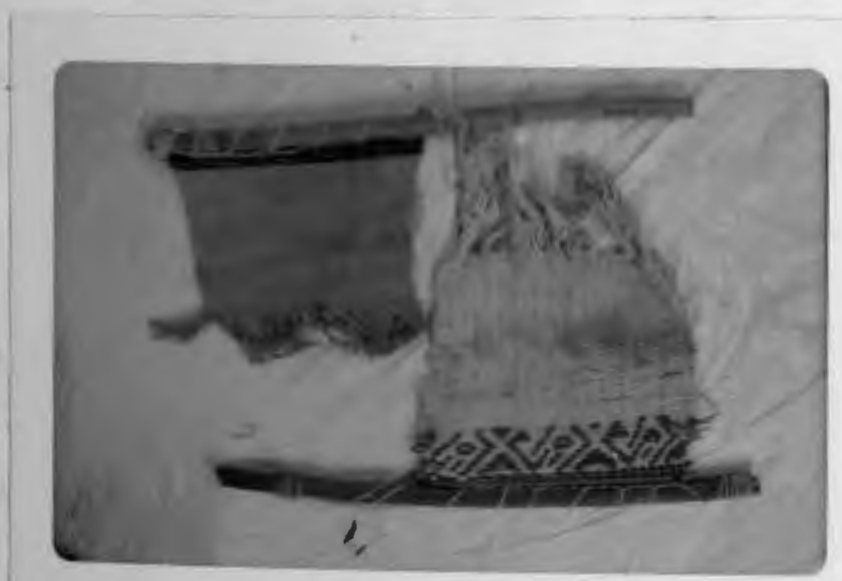

Single or one-pick heading cord. Source: National Museum - of Natural History, \#325019, 325020.

Fgure 37. Mothods of attaching warp to loom bars (heading cords). 


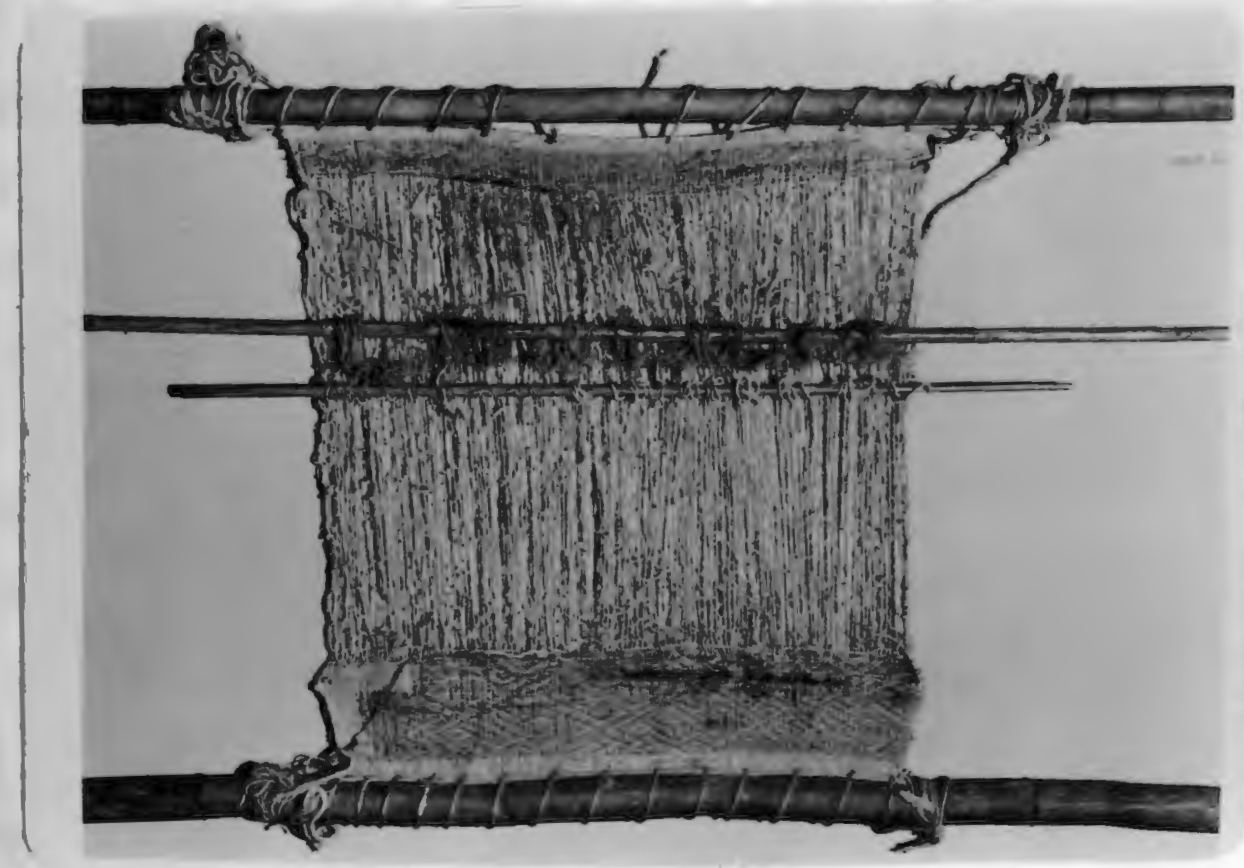

Pigure 37 (Cont.). Peruvian loom, three picks or wefts are under the lashing cord.

Source: Courtesy of American Museum of Natural History. 
After the textile is taken from the loom, the onepick heading cord can easily be removed without a trace, two-pick and three-pick heading cords will remain in the textile or leave exposed warp loops.

Generally the first wefts, whether tied to the loom bars as heading cords or only used as the beginning wefts, are the regular weft yarns of the textile which are grouped in pairs or several singles. The size of this cord seems to correspond to the purpose of the textile-they are oversized in tapestry and doubled or tripled in finer materials. An interesting treatment of two different wefts was found in the double cloth specimen \#38.030 from the Late Intermediate Period (Museum of Art, Providence). Here two-double wefts interlocked at the opposing side selvages.

Each tẹchnique, either one, two or three-pick heading cord, requires a certain weaving procedure (Figure 38 ). 4ccording to Bird ${ }^{76}$ and Cordry, 77 the set-up with a one-pick heading cord is as follows: The warp is kept under tension with the help of two-auxiliary loom bars. The permanent loom bar is placed on top of the warp. The heading cord is passed between the two-warp planes and tied to the permanent loom bar. Then the warp is lashed to the bar in a spiral manner. After this, the backstrap is transferred to the permanent loom bar and the auxiliary bar is removed. The loom bar 

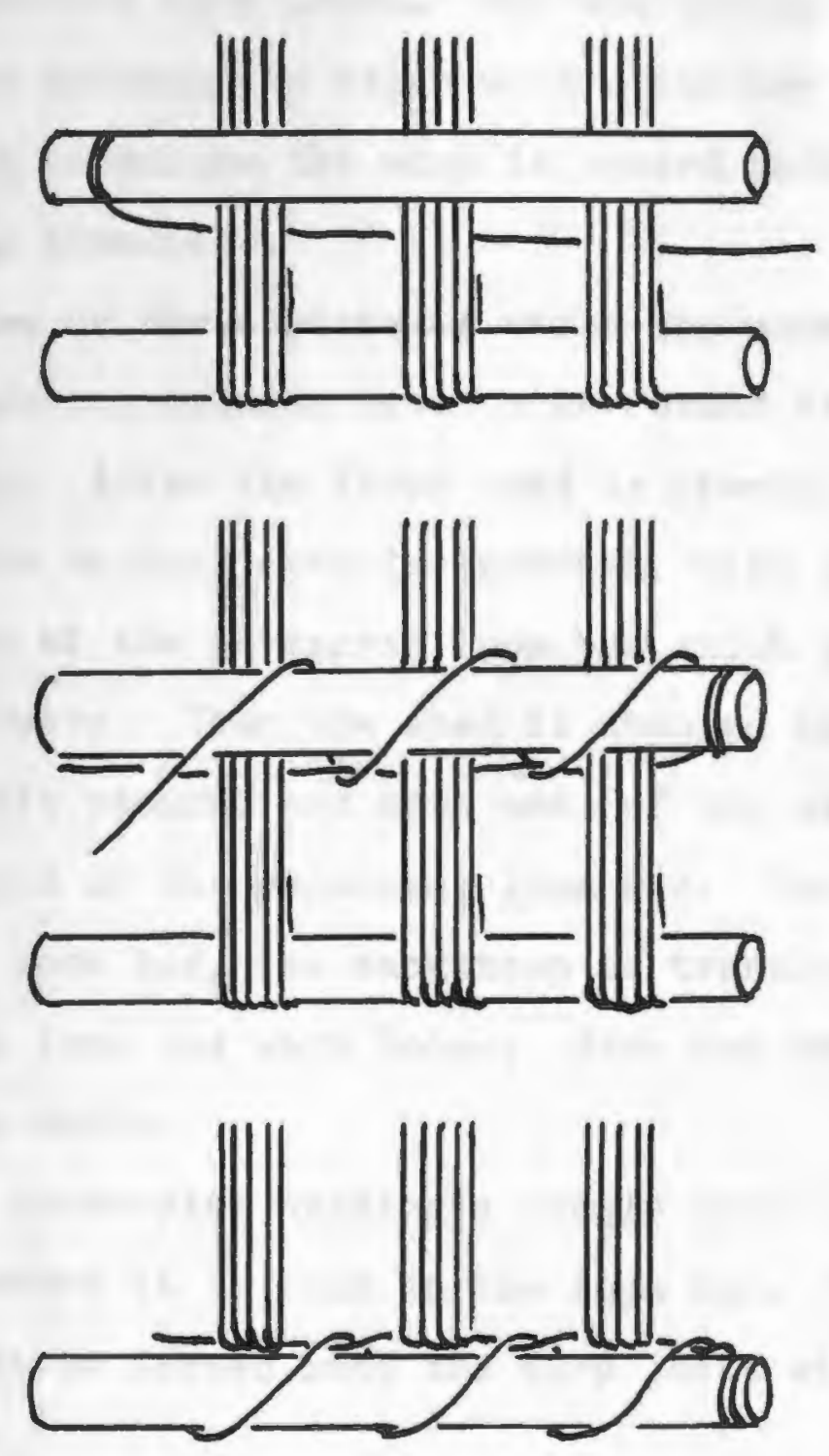

Figure 38. Loom set-up.

Source: Donald and Dorothy Cordry. Costumes and Weaving of the Zoque Indians of Chiapas, Mexico. Southwest Museum Papers 15, Los Angeles, California, p. 194 . 
slips back into the warp loops. Now the string heddles are formed and the weaving can begin with a heavier or regular weft. In this technique the warp is spaced before the actual weaving commences.

When two or three picks or wefts are under the lashing cord, the string heddles have to be formed first on the stretched warp. After the first shed is opened, half of the weft of the heading cord is inserted, tied to or looped around the end of the permanent loom bar which is on top of the stretched warp. Then the shed is changed and the other half of the weft returns and both ends of the weft are tied to the other end of the permanent loom bar. The warp is lashed to the loom bar, the backstrap is transferred and the loom bar slips into the warp loops. Here the warp is spaced by reaving two wefts.

With a three-pick heading a single weft is inserted three times before it is tied to the loom bar. Then the loom bar has to be forced into the warp loops with a good jerking motion.

In summary there is no single treatment of the warp selvages. Generally a heavier yarn is used although this is not technically necessary. Only the lashing cord is necessary. A heavier weft probably produces a flat edge which does not curl up as easily. 
The weaving of one, two or three-pick heading cords does not seem to be restricted to certain periods, although the one-pick technique is most preferred in later times. The one-pick technique is fast and leaves no trace in the textile, while the two-pick technique acts as an excellent spacing device. No half-hitch lashing was encountered in Peruvian looms.

\section{Side Selvages}

A selvage treatment which would require a change in the weave, as from a plain to a basket weave, is not practical due to the string heddles which are formed with a continuous yarn on an open shed. This would mean that the warp yarns involved in the selvage would have to be rearranged on the lease sticks before the string heddles are formed. It would be much easier to work with double or heavier yarns at the selvage, and the best is to take advantage of the absence of the reed and have a closer warp set at the sides.

0 Neale states that "the Peruvian weavers did not think it necessary to reinforce the side selvages."78 They worked with closer warp densities (Figure 38), and with a weft treatment if a flat selvage seemed to be of importance (Pigure 39). Three wefts were woven successively before they were returned. O'Neale reports of this technique from several Supe gauzes dated from the Middle Period but did not suspect this reason. 79 

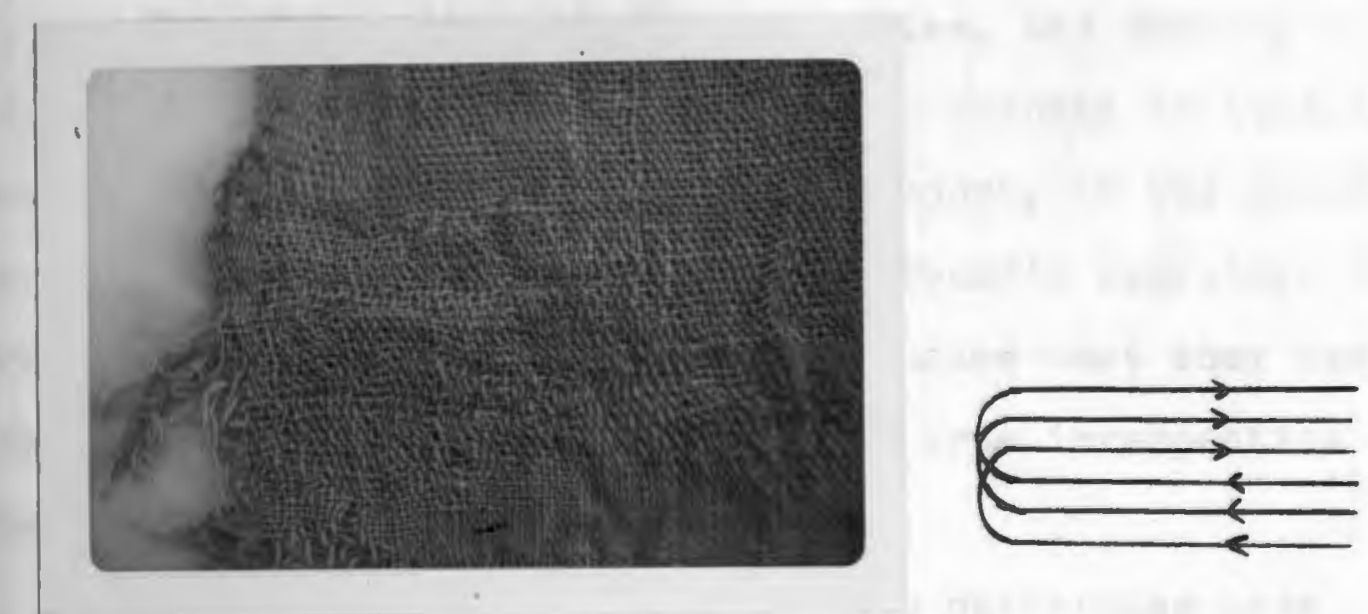

Providence, Museum of Art. No number.

Weaving with three shuttles.

Figure 39. Side selvages.

\section{Absence of the Reed}

The continuous warp set-up rules out the use of a warp spacer and beater. This positively allows for extreme freedom and Ieads to: (I) deflected warp yarns towards both sides, (2) gauze which involves a crossing of warp yarns with weft yarns securing the crossings, (3) shaping of the textile through changes in warp densities, and (4) interlocking of warp yarns. Negatively it will lead to: (1) uneven weaving or yarn shifting in the woven web when the warp count as well as the yarn size are low, and (2) narrowing of the woven width during weaving. 

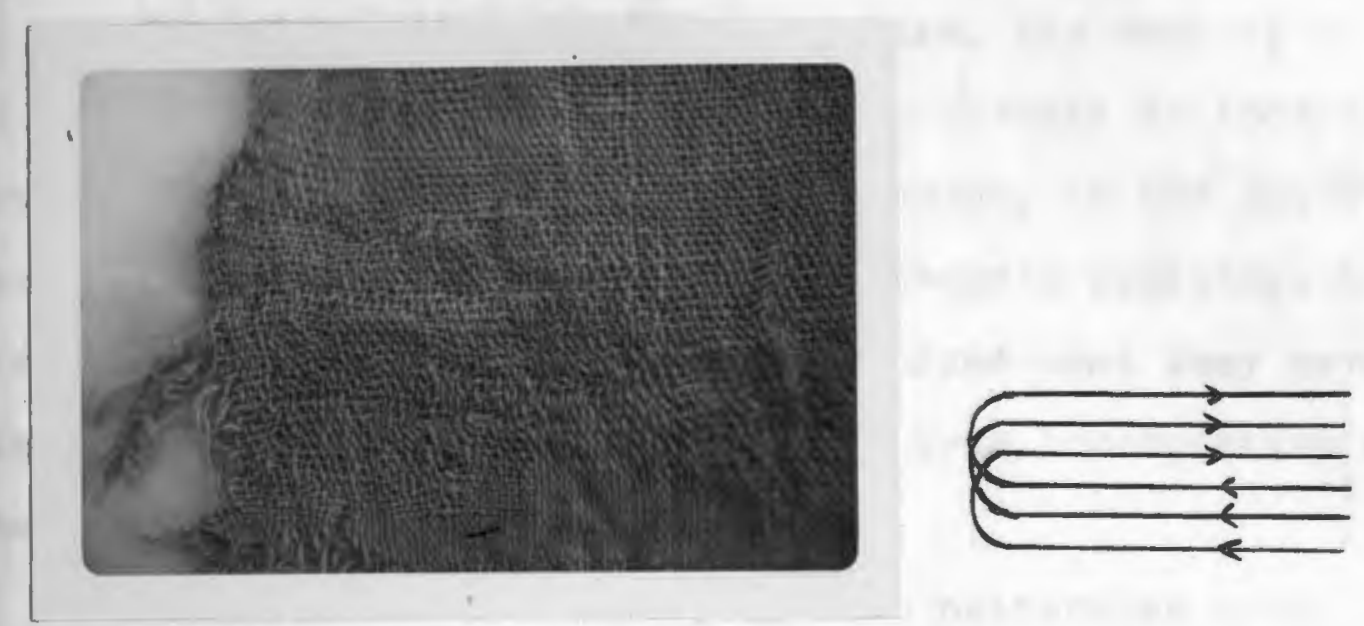

Providence, Museum of Art. No number.

Weaving with three shuttles.

Figure 39. Side selvages.

\section{Absence of the Reed}

The continuous warp set-up rules out the use of a warp spacer and beater. This positively allows for extreme freedom and leads to: (1) deflected warp yarns towards both sides, (2) gauze which involves a crossing of warp yarns with weft yarns securing the crossings, (3) shaping of the textile through changes in warp densities, and (4) interlocking of warp yarns. Negatively it will lead to: (I) uneven weaving or yarn shifting in the woven web when the warp count as well as the yarn size are low, and (2) narrowing of the woven width during weaving. 
Density or Sett

In conjunction with the yarn size, the density or sett of a textile determines if a fabric is closely or loosely woven. It is expressed in the cloth count, in the number of warp yarns and weft yarns per inch. Today's backstrap loom products tend to be warp faced which means that they have a higher warp than weft count. This is true irrespective of the technique.

Peruvian fabrics employing warp patterning have generally a warp count which is double or higher than the weft count. Guatemalan fabrics woven in a weft patterning have the same proportion of warp-weft as the Peruvian fabrics in the ground or base fabric. The pattern weft is supplementary and is actually an inlaid weft which floats in the design areas on the face of the textile and is carried in the base fabric or floats on the reverse side as seen in the Peruvian Mchaeological fabrics. Contemporary Aymara ponchos are Generally warp-faced and so are much of the Inca plain weave garments 80 (Figure 40).

Cloth counts of Peruvian pre-Columbian textiles are not readily available. O'Neale reports that the proportion of warp-faced plain weave among 650 textiles from early, middle and late periods from the coastal regions stayed the same (Early 19.16\%, Middle $21.62 \%$, Late $20.29 \%)^{81}$ and among the late-Late Period textiles were mostly represented in 


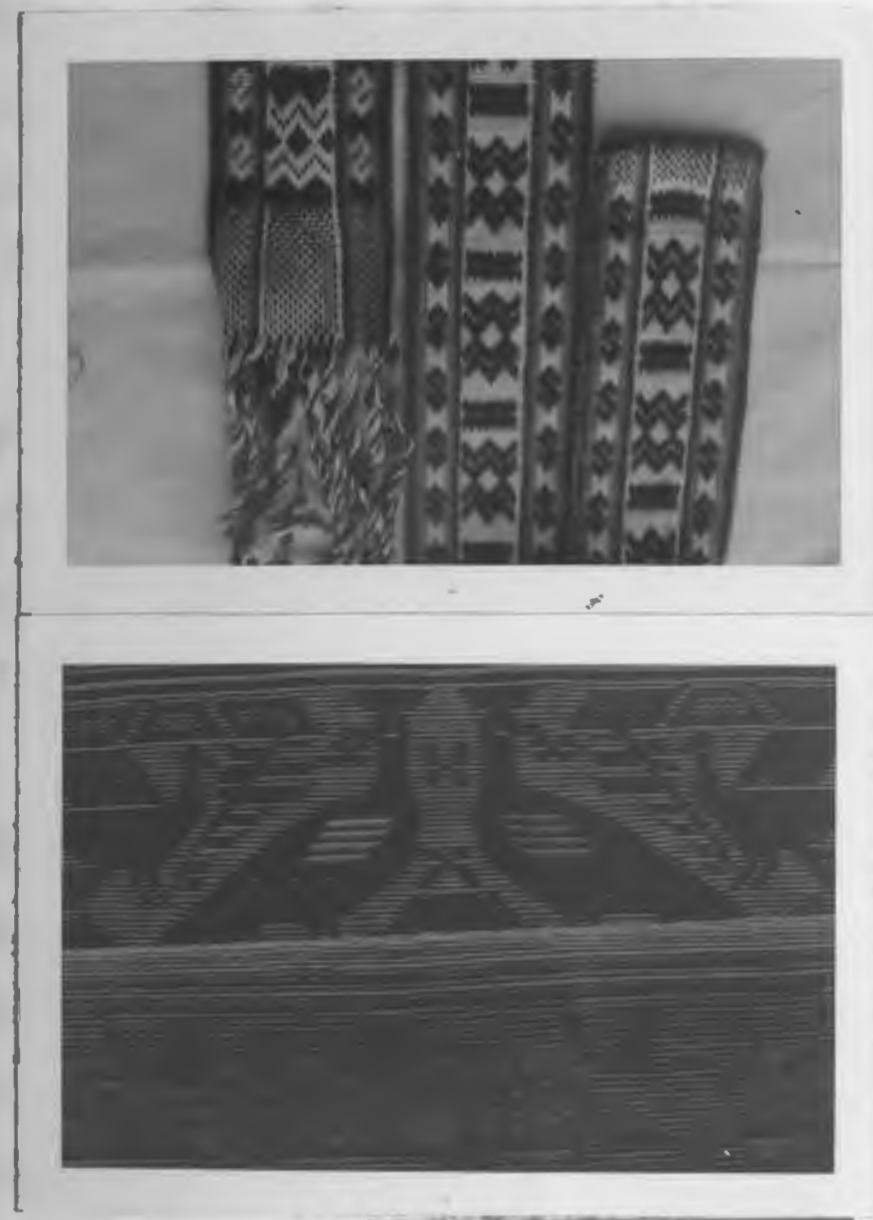

$39 \times 16$ warp pattern, Peru

$140 \times 20$, warp pattern, Peru

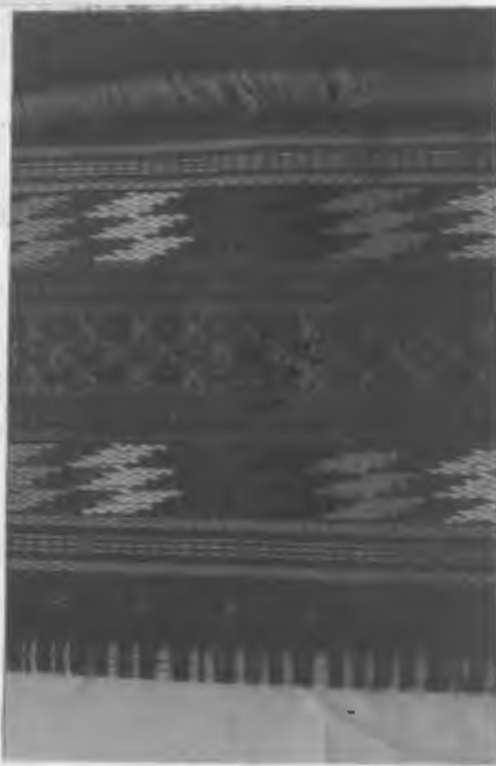

$38 \times 18$, weft pattern, Guatemala warp - 2 ply weft - 4 singles Textiles owned by author.

Fignre 40. Narp densities. 
Chincha with 27 percent, Chimu 12 percent, Chancay 4 percent and Nazca Ica 2 percent. This indicates that if there is any increase in warp-faced plain weave textile, it occurred after the Late Period.

The pre-Columbian textiles have a wide variety of densities, determined generally by the purpose of the fabric or by the technique which is used. Shifting of warp and weft yarns does occur in loosely woven textiles as seen in (Figure 41).

Any spacing or density, other than the one determined by the proximity of the yarns themselves, has to be initiated at the loom bars and fixed with the spiral lashing cord, and preserved by careful weaving including tension control and weft length. Obviously this requires more attention and skill from the weaver and prolongs the time for this initial warp set-up.

Even weaving width is maintained today as it has been before with a tenter which consists of a cane rod to which cactus thorns are tied at both ends. Today, nails replace the cactus thorns (Figure 42).

However, any grouped yarn interlacement so popular with handloom weaving becomes somewhat distorted when woven on a frackstrap loom. The undulations of the weft do occur since they are based on the threading and treadling sequence, but the realignment of the warp yarns does not function due to the missing warp spacer (Figure 43). 


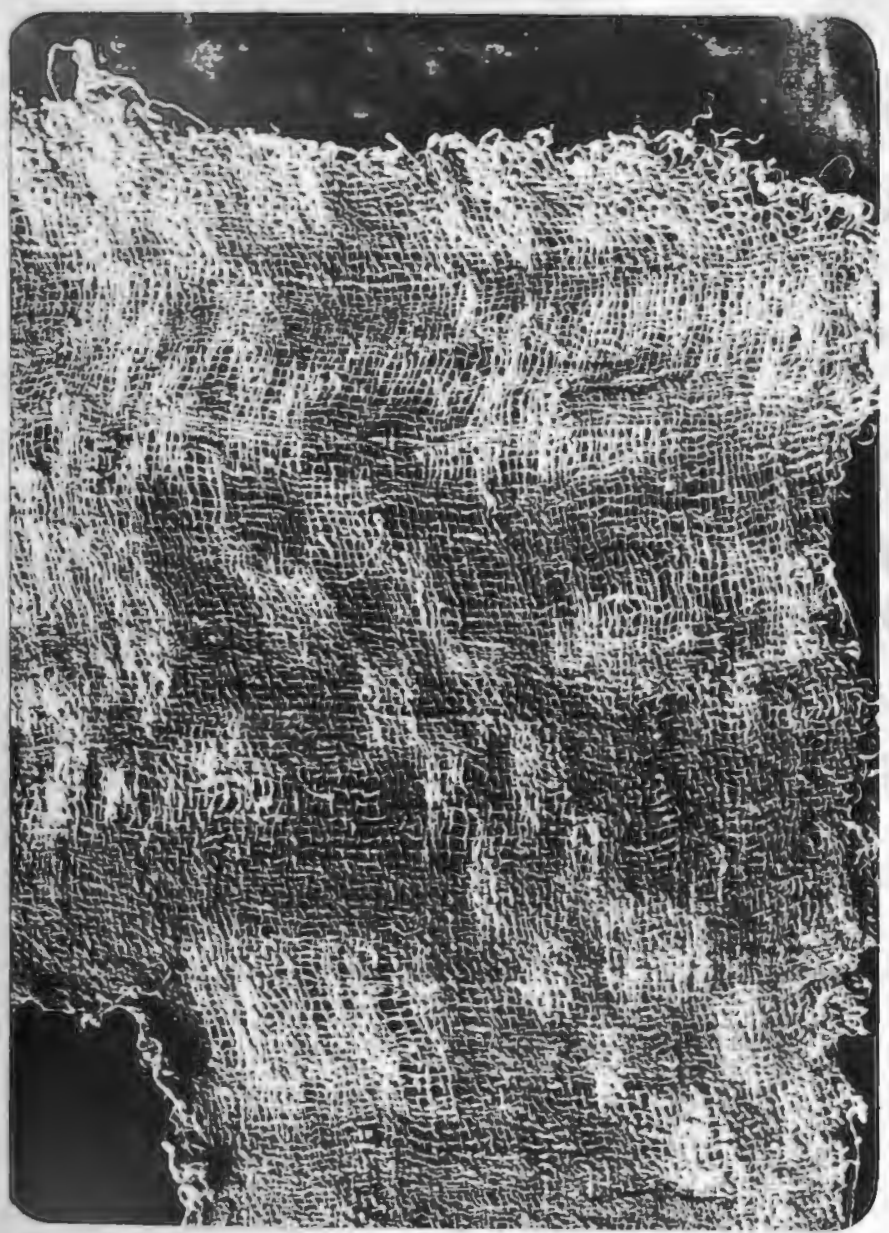

Figure 41. Yarn slippage.

Source: Courtesy of the American Museum of Natural History. Neg. 3244326 warp ikat, cotton. 


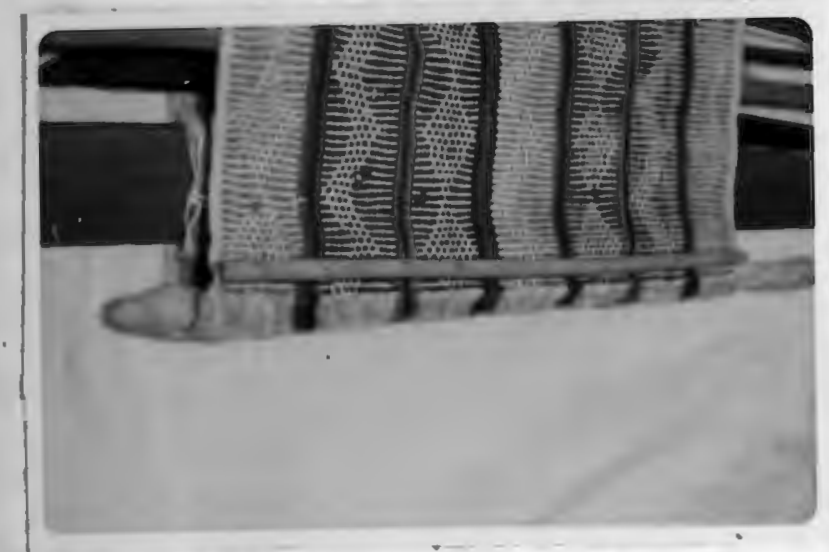

A400/4566 American Museum of Natural History

Figure 42. Ethnological Loom with Tenter. Harness
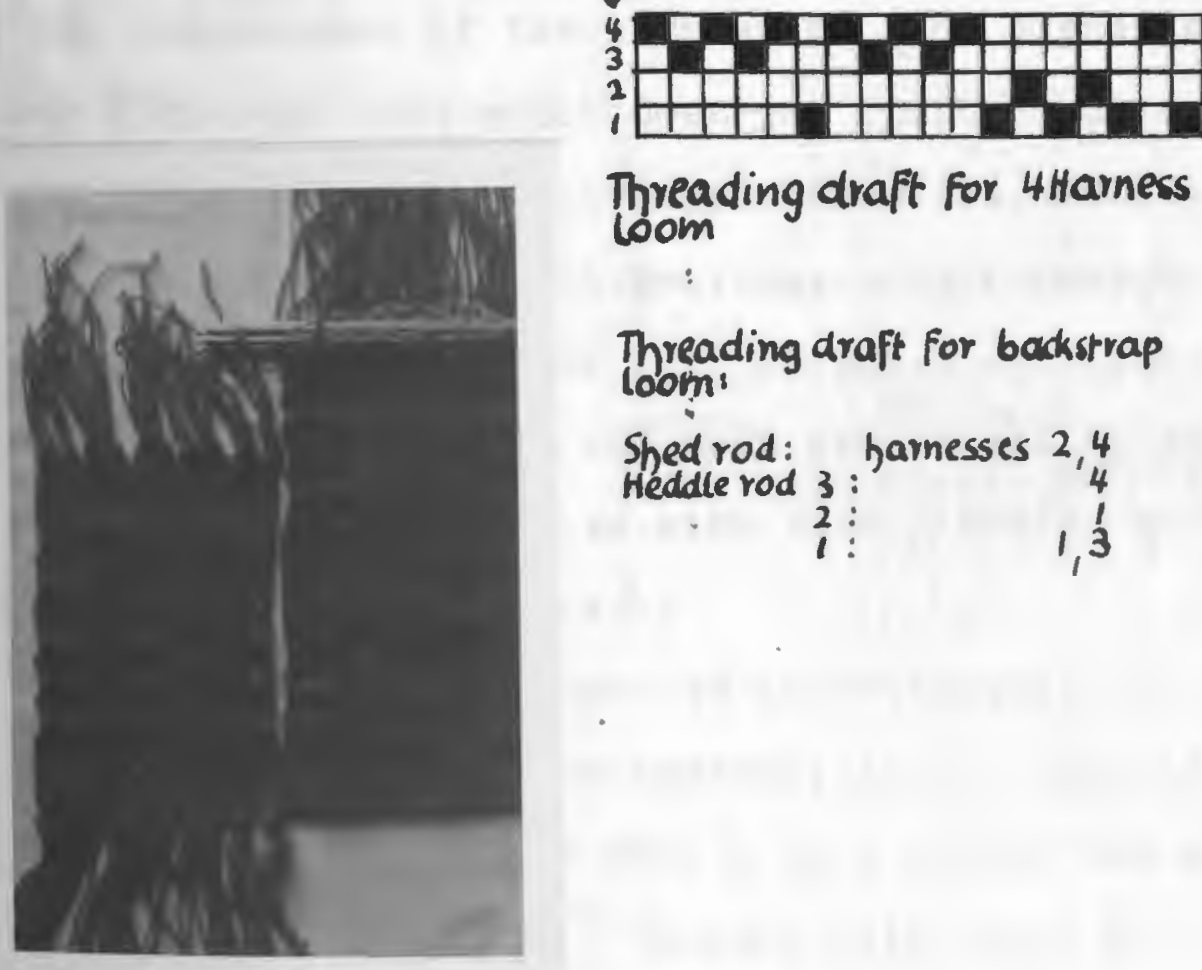

Threading draft for badkstrap Coom:

Shed rod: Heddle rod 3 i:
From: $\frac{\text { Tenter }}{\text { Roth, H. L. }}$
Studies in primitive
looms, Man, Vol. 46,
1916, p. 304.

From: $\frac{\text { Tenter }}{\text { Roth, H. L. }}$
Studies in primitive
looms, Man, Vol. 46,
l916, p. 304.

From: $\frac{\text { Tenter }}{\text { Roth, H. L. }}$
Studies in primitive
looms, Man, Vol. 46,
1916, p. 304.

From: $\frac{\text { Tenter }}{\text { Roth, H. L. }}$
Studies in primitive
looms, Man, Vol. 46,
l916, p. 304.

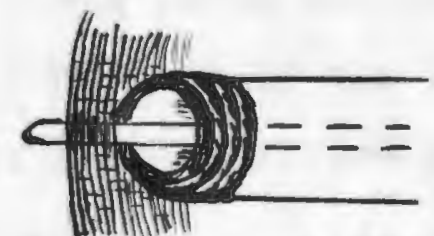


It is interesting to note that the use of crepe yarns (highly twisted single-ply yarns) increased from 13 percent in the Early and Middle Periods to 44 percent in the Late Period, and the proportion of slack yarns decreased from 11 percent in the Early Period to 2 percent in the Late Period with being absent from the Middle Period (Figure 40). 0 'Neale speaks of the "bite" of crepe yarns which "aids in maintaining the parallel position of the wefts." 82 (Figure 44)

Actually the crepe yarns, when woven on a backstrap loom or any other loom, produce a sheerer fabric mainly due to the compactness of the yarn size. The higher twist produces a rounder yarn which does not flatten out in the web and thus retains its grainy appearance (Figure 45 ).

In the experimental weaving, a $20 / 2$ cotton yarn was plied with three turns per inch (t.p.i.) and 18 turns per inch. In sample 1, warp and weft are alike; in sample 2 , sections 1 and 2 were woven with $20 / 43$ t.p.i. as weft and section 3 with $20 / 418$ t.p.i.

The cloth count remained approximately the same, but the appearance changed considerably from a soft, full textile to a translucent one with a hard grainy texture. Also the weaving was affected. Weaving with crepe yarns is more difficult since the warp yarns have to be held under constant but varying tension between the weft insertion and the beating 


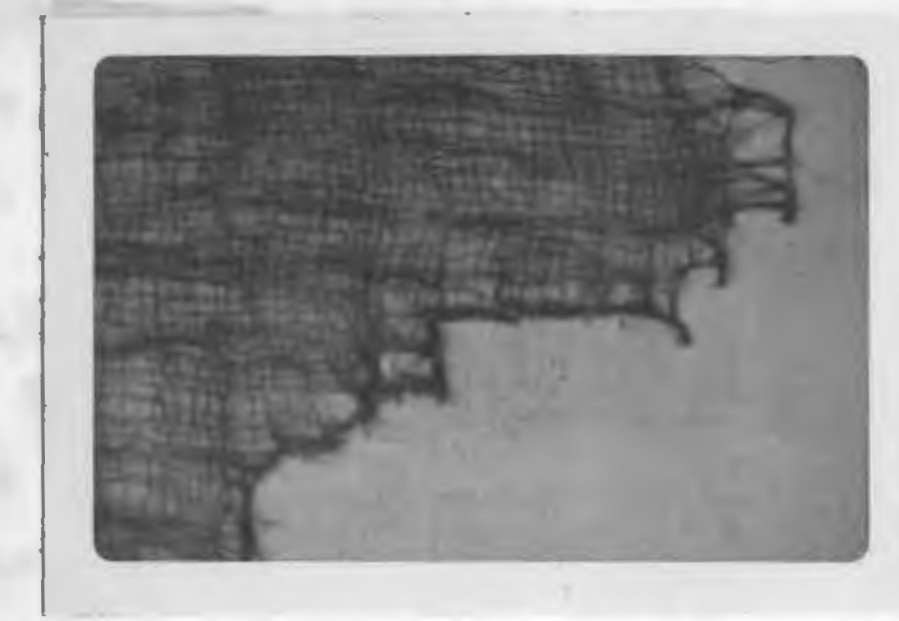

Figure 44. Gauze woven with crepe yarns. Source: Note: \#13.015 Providence Nuseum of Art. Plain weave, low count crepe yarns, single ply - count $22 \times 20$.

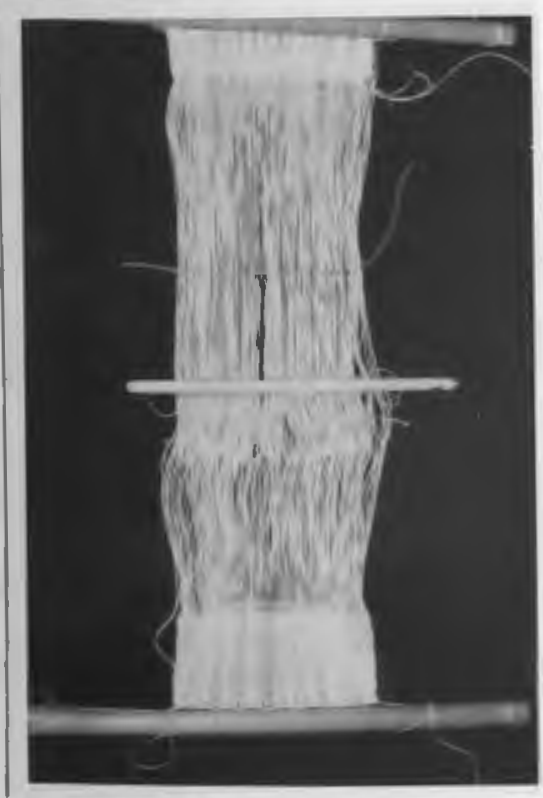

1 - cotton $20 / 4$ with 3 t.p.i. (warp and weft)

Count $32 \times 20$

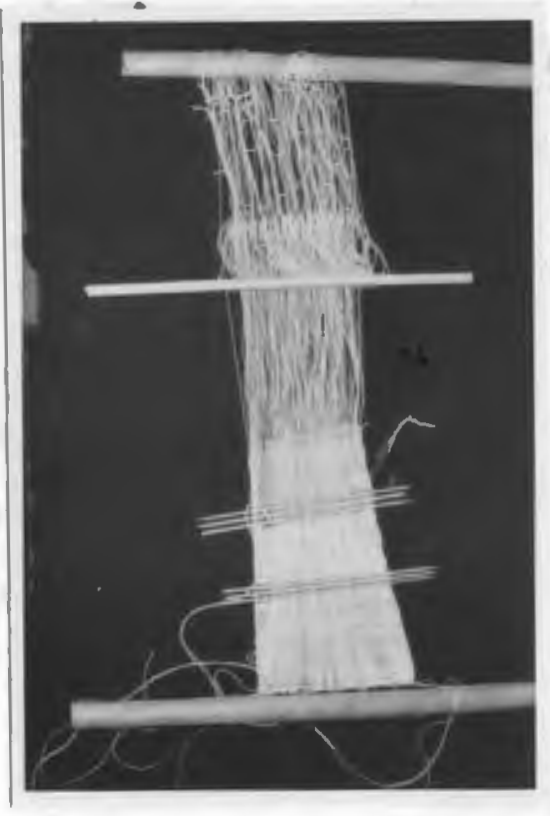

$2 c$

$2 b$

$2 a$ 2 - $\underset{\text { (warp) }}{\operatorname{cotton} 20 / 4}$ with 18 t.p.i.

a. with filling 3 t.p.i. count $30 \times 20$

b. with filling 3 t.p.i. count $32 \times 19$

c. with filling 18 t.p.i. count $34 \times 19$

Figure 45. Experiment: weaving with low and high twist cotton yarns (woven by the author). 
of the weft to the woren web, and easier with regard to the clearing of the shed. The shed opens smoothly and wearing with crepe yarns proceeds rapidly due to the high twist and, therefore, compactness of the yarns.

\section{Deflected Warp Yarns}

D'Harcourt describes these as decorative non-parailel warp yarns which form a lozenge design either on the surface only, or on both the face and back of the fabric. ${ }^{83}$ He assumed that "the technique may, perhaps, have been in its infancy." 84 He did not realize that the technique has its own design limitations.

Deflected warp yarns are supplementary warp yarns which, in the absence of the reed, may be deflected to the right and left on a plain weave ground. Tidball describes such a fabric from the collection of the Detrolt Institute of Arts. 85

The supplementary warp yarns are in pairs with one base warp yarn between them. The regular weft binds the pattern warps with the base warp between them into the base fabric.

Weaving with deflected warp yarns on the backstrap loom is simple. When the design is only on the surface of the fabric, the pattern warp yarns float over a pattern stick which rests on the regular shed rod. At the binding points a pick-up stick is inserted into the open shed and the pattern warp yarns are pressed into the lower shed. The regular weft is woven, the pick-up stick is removed 
and the next plain weave interval is woven. In this method there is an even number of warp yarns between each pair of pattern yarns as well as an even number of weft yarns between each "pick-down" or deflection.

When the design floats are on both sides of the fabric, then the supplementary warp yarns float underneath the base warp and will be picked up into the weaving shed with a string heddle rod and one pick-up stick (Figure 46).
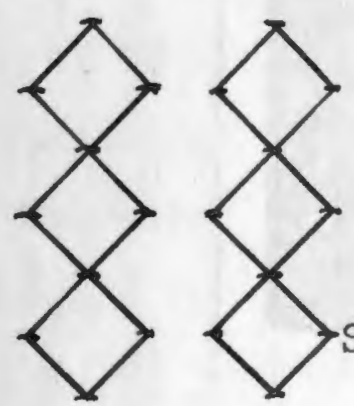

on top

design on surface
Supplementary warp floats

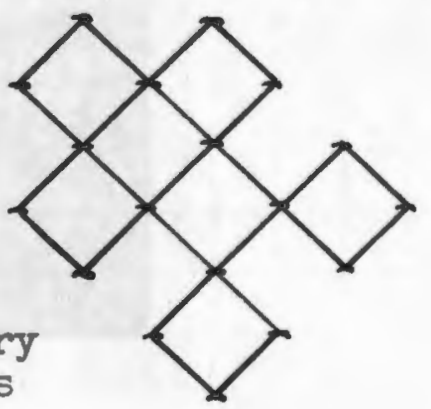

on bottom

design on surface

and bottom

Figure 46. Deflected warp yarns.

Although no deflected warp yarns were found during this study, one fabric had a similar appearance. But it does not require the absence of the reed. Specimen 43.091 , Museum of Art, Providence displays alternating rows of crosses which were woven with supplementary warp and weft yarns (Figure 47). 


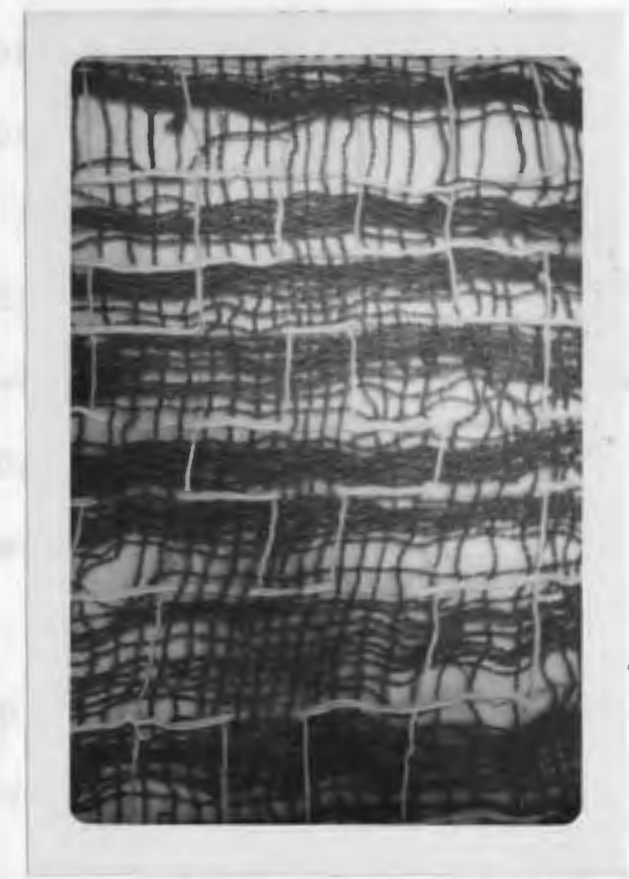

tupplementary warp and weft yarns of white 2 ply wool on plain weave base, fabric of red 2 ply wool. cloth count $6 \times 8$.

Warp set-up: 4 red, I white Design is accomplished with 2 wefts ( $a$ and $b$ ) Alternating: $a, b, b, a, b, b$, etc.

Figure 47. Supplementary warp yarns. 
Interlocked Warp Yarns

With the absence of the reed, the loom can be equipped with interlocked warp yarns in order to weave areas of pure color in a balanced weave or to have color changes in the warp direction in a warp-faced fabric.

Two basic types of interlocking exist: (1) interlocking of two-warp yarns at the point of the color change, (2) interlocking of warp yarns over a scaffold weft. If the weft is withdrawn, the two zows of warp loops will sepatate (Figure 48).

The warp set-up is important for both and can be done on a warping board.

Figure 48. Types of interlocking.

1.

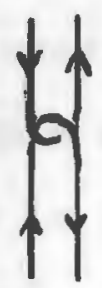

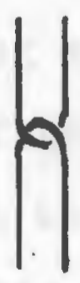

Warping techniques
2.

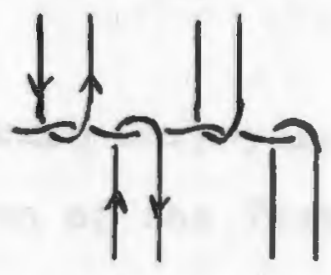

Each horizontal line of color change is represented by a peg on the warping board:

1. One of the two interlocked yarns is placed around the peg. The peg only serves as a measure to have the interlocking done at equal lengths.
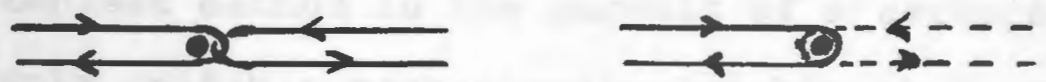

2. Both warp yams encircle the same peg alternately. The peg functions as part of the weave. The complete set up can function as a loom. When the weaving approaches one peg, a regular weft or scaffold weft has to replace the peg. 
The small warp set-up \#7.320 767 in the collection of the Peabody Museum, Harvard University is an example of warp interlocking which relies on a connecting weft (Figure 49).

Figure 50 shows the restored warp set-up of the same interlocking technique without the pegs and with scaffold wefts. The specimen \#41-0-1561 is in the American Museum of Natural History, New York. Dr. Bird assumes that the scaffold wefts "presumably are held in place by supplementary bars at right angles to the regular ones." 86 This set up is only workable with a very high tension on the scaffold wefts and a low tension on the vertical interlocked yarns. A better warp control could be achieved if the warp tension is applied to warp yarns which are interlocked over pegs and each peg is only removed and replaced by a scaffold weft when the weaving approaches.

An example of true interlocked warp yarns without scaffold wefts is in the collection of the Textile Museum, Washington, D. C. Of great interest is that heddle rods and shed rods are used where ever it is possible. The weaving proceeds from the outer edges of the color areas to the center. It can be interpreted that the Peruvians would select the simplest method in the pursuit of a certain end effect and apply suitable mechanization within their knowledge (Figure 51). 


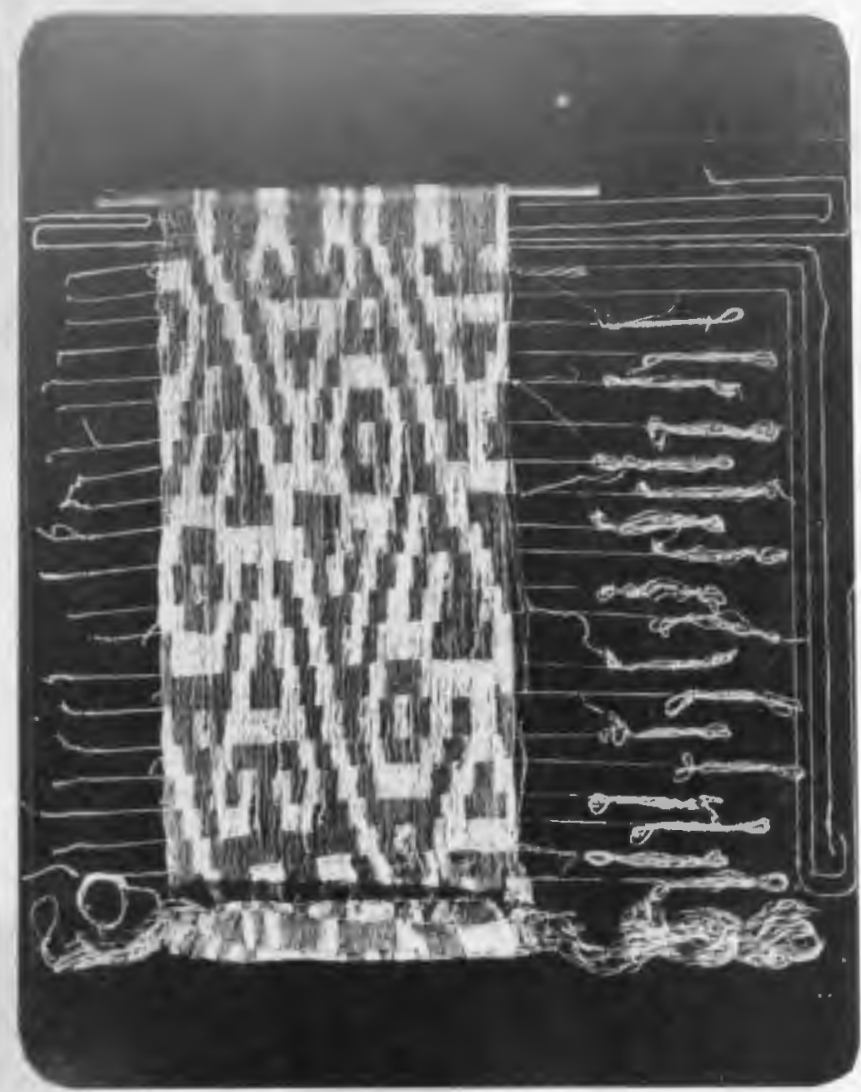

Figure 49. Interlocked brown and white warp yarns. \#41-0-1561. American Museum of Natural History. Source: Harriet Tidball. Peru: Textiles Unlimited, Part I, p. 28. 


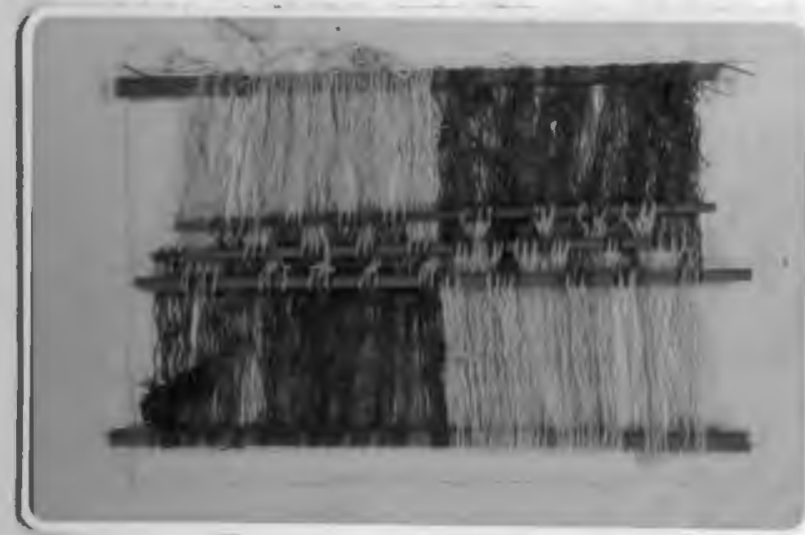

Figure 50. Set-up of discontinuous warp.

Source: Peabody Museum, Harvard University (\#7.320 767).

Note: Brown and tan cotton, 24 ends per inch, 5 inches high.

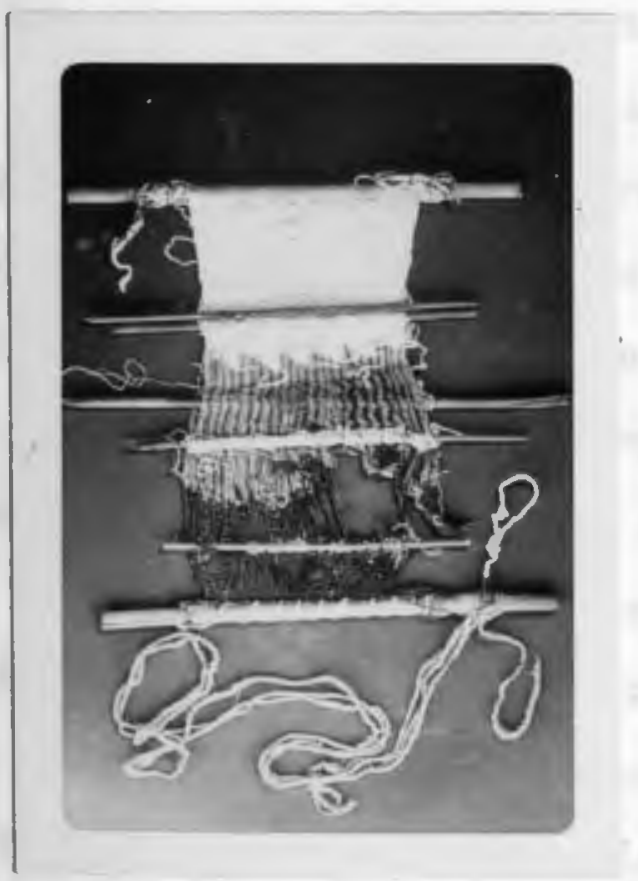

Figure 51. Loom with interlocked warp yarns.

Source: Textile Museum (\#1568.15).

Note: Cotton (white, blue, and 2 shades of brown). South Coast, probably Late Intermediate Period. 


\section{Loom Shaping}

Today weaving to shape is a challenge to the handweaver, and is an expression of his imagination and skills. Loom shaping was widely used in Peru, more than genorally was realized, and known prior to the pre-Tuahuanaco period. The Peruvian did not have tailored garments until the Spaniards arrived. The clothes were woven to size, based on the rectangular shape and if necessary included shaping during the weaving process. There were: (1) bags or pouches with a wider base than top, (2) breech cloths to fit the contour of the body, (3) shirts, wide on the shoulder and narrow on the bottom and (4) garment articles, presumably serving as headdresses.

Loom shaping is not restricted to one particular loom. However, the backstrap loom is more suitable for it, because of the absence of the reed and the simplicity of the string heddle set-up. It offers possibilities which are only limited to the imagination of the weaver.

The shaping is done in conjunction with several weaving techniques, based on their structural value besides their decorative appeal. These are double cloth, interlocked warp, tapestry, warp-faced plain weave and variations of plain weave. The Peruvian weaver seemed to have worked with the following shaping techniques which he selected according to the desired results and end effects: 
1. To vary the width when the number of warp yarns remains constant by: (1) spreading or condensing the warp yarns to the desired width, (2) increased or decreased weft tension, alone or in conjunction with a change in the weave structure from single to paired warps or vice versa.

2. To vary the width when the number of warp yarns changes by addition and/or subtraction of yarns.

3. To alter the shape by non-parallel alignment of the loom bars and/or the use of multiple loom bars with varying warp lengths.

4. To alter the shape by interchange of warp to weft or vice versa.

lieriations in width with a Destant number of warp yarns

The simplest technique and probably the one most comnonly practiced was to set the warp yarns to the desired width at the opposite loom bars. A heading could be woven to establish the width and the loom join would fall anywhere between the two parts of weaving. The two specimens \#24.277 and \#24.276, Museum of Fine Arts, Boston are examples of a decrease in width, from $8 \frac{1}{2} "$ to $4^{\prime \prime}$, and from $7 \frac{1}{2}$ " to $5 \frac{1}{2} n$ (Pigare 52). 

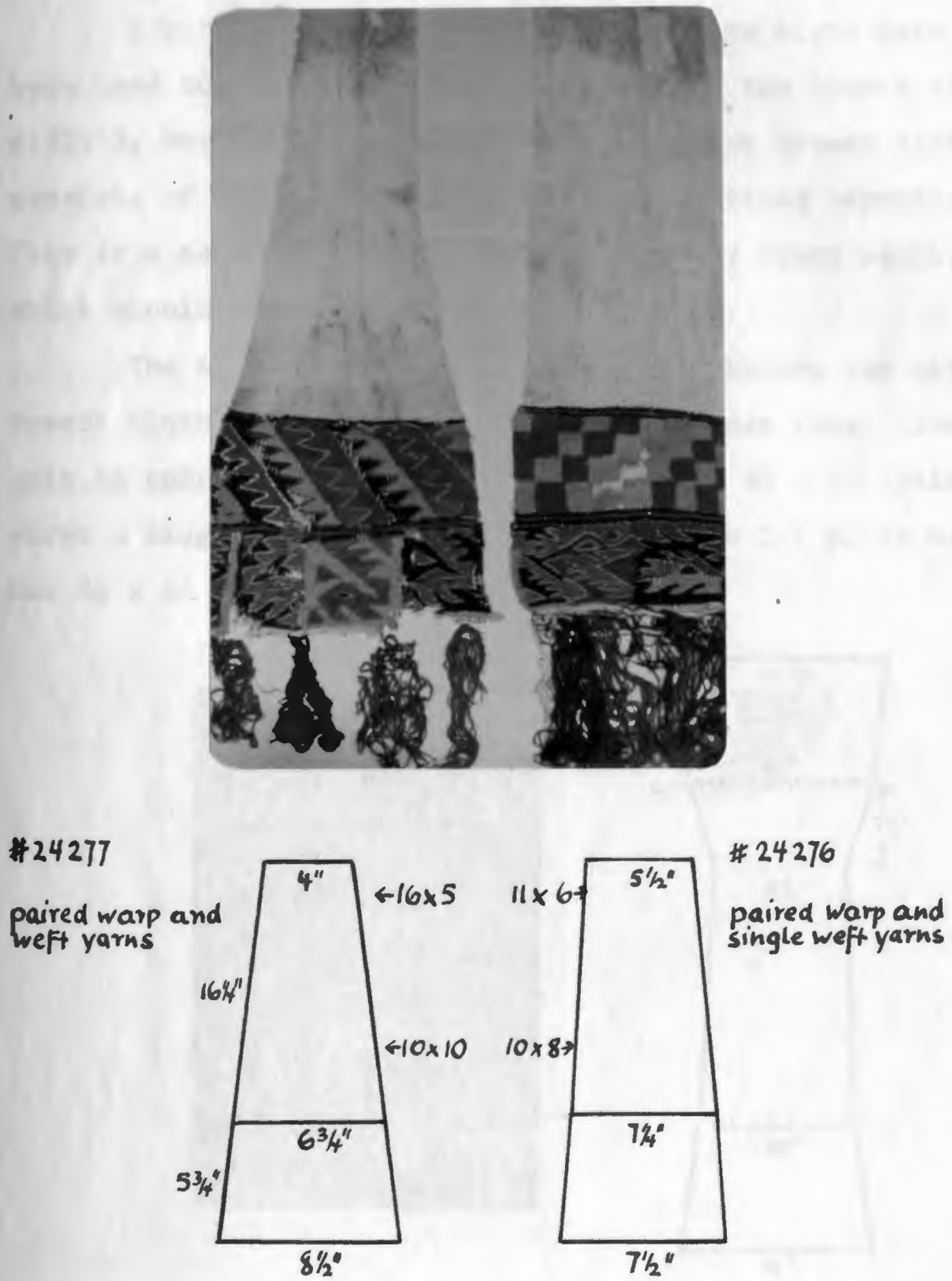

Figure 52. Loom shaped weaving.

Source: Note: \#24277, 24276, Museum of Fine Arts, Boston. (Both ties are woven with paired warps, in the plain weave as well as in the tapestry section.) 
A varying weft tension during weaving might have been used to achieve the slight shaping in the breech cloth \#192153, Worcester Art Museum. Actually the breech cloth consists of three woven pieces which are joined together. This is a necessity with the weft patterned front section which should hang from the waist when worn.

The narrowest part of the center section, the actual breech cloth is $8 \frac{1}{2} "$ and is $7 \frac{1}{2} "$ below the seam line. The join is poorly woven with a cloth count of $20 \times 20$ (paired warps $x$ single wefts) while the rest of the $2 / 1$ plain weave has $24 \times 48$ (Figure 53).
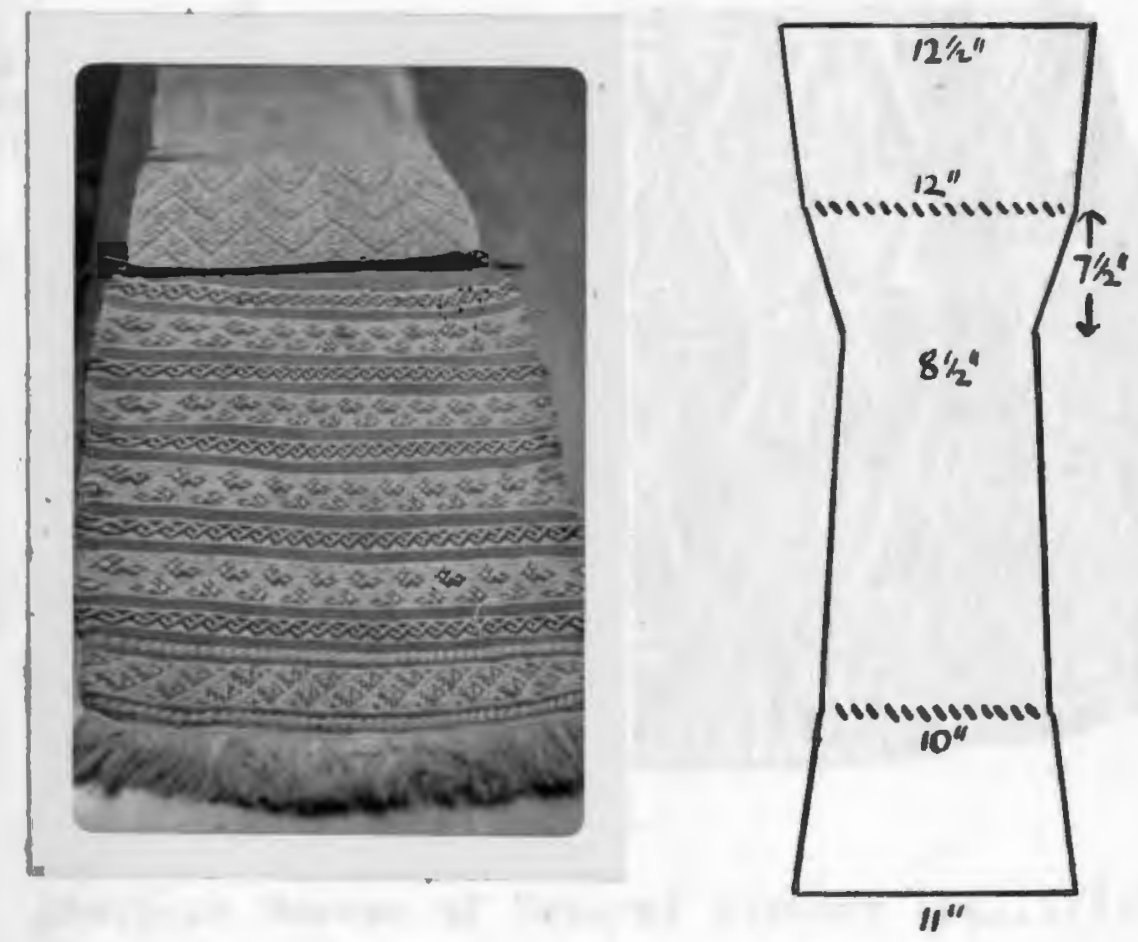

Figure 53. Loom shaped weaving.

Source: Worcester Art Museum, \#192153. 
The change in width of a parallel warp through increased or decreased weft tension is limited and proportionately tied to the length and elasticity of the warp yarns.

Also the curvature is important: a concave curve is asily obtained, a convex one less easily. Here a buckling or pleating effect would be the result. Width differences, larger than this limiting factor, have to be woven in a certain sequence (Figure 54 ).

Figure 54. Loom shaped weaving.

Top width 9"

Bottom width $11 \frac{1}{2} n$ Length of bag 8 :

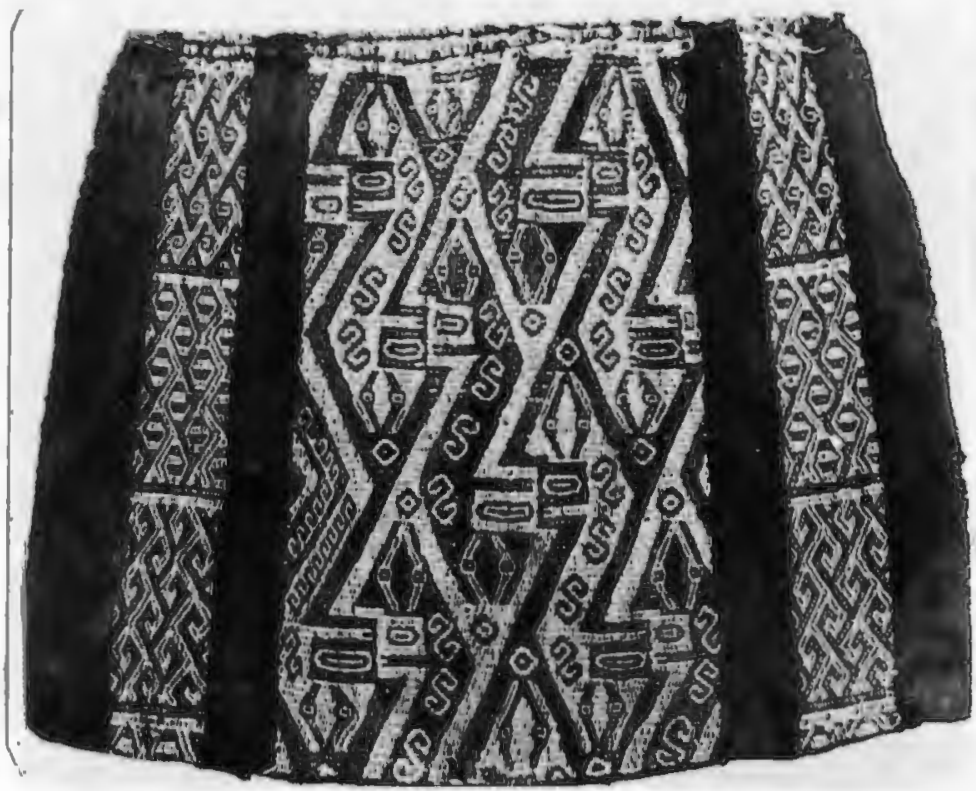

Source: American Museum of Natural History (\#41.1/5357). Hote: This warp pattern bag from Arica (Chile) is of wool, woven in one piece and folded at the middle and seamed at the sides. 
The patterned center strip decreases one inch from bottom to top and the cloth count reads $64 \times 20$. Bird assumes that the weaving started at the loom bars and met at the center which is the widest section of the bag. ${ }^{87}$ It is possible to weave this bag with a decrease in weft tension and thus effect an increase in width of about threemarter inch at both sides.

However, the following technique would be easier and has to be used with larger differences in the width: the warp is spread so that the desired width is at the planned height. Weaving would begin at one loom bar (a) and proceed until (b). With the new width firmly secured, the loom is turned around, and after the warp width is decreased at the loom bar (c), the weaving is completed and ends at the wider section (Figure 54).

\section{Figure 54 (Cont.). Loom shaped}

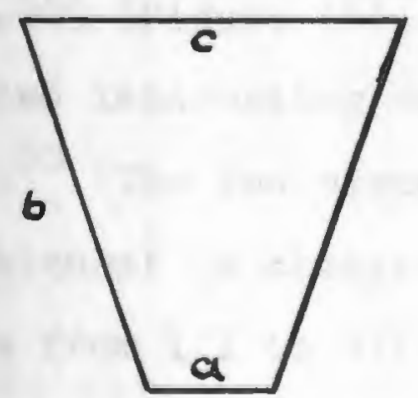
weaving.

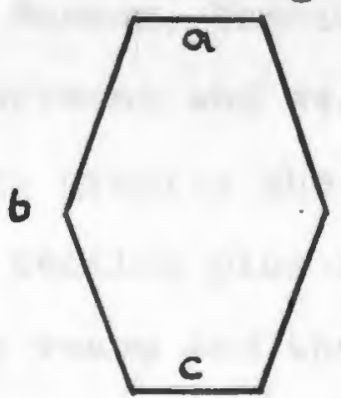

Note: Sequence of weaving for large width differences. 
The tapestry woven bag is woven in one piece, folded, doubled and closed at the sides, and is wide at the bottom and narrower at the top (Figure 55). Bird observed that a heavy cord of three-strand cotton is twined over two warp yarns at the bottom of the bag which is considered the center of the warp. 88 This observation could be the clue to how the piece was shaped. The Navaho weavers use a row of twining for warp spacing before they start to weave. Half of the unwoven warp can be rolled up, the twined weft serves as the base and the weaving proceeds from the center to the loom bar, weaving $1 / 1$ and then $2 / 1$ at the top. Then the loom is turned around and again the weaving commences at the center. This technique may explain weft insertion next to the twined cord. 89

The scarf (Figure 59) and an experimental sample was actually woven in this sequence. TM 91.483 and TM 1959.209 (Figure 56), Textile Museum, Washington, D.C., are two interesting shaped specimens and well described by King. 90 The two pieces seem to display the same shaping techniques: a change in weft tension plus a change in the weave from $1 / 1$ to $2 / 1$ tapestry weave and then to warp-faced plain weave effecting a narrowing of $20.5 \mathrm{~cm}$ within a length of $95.5 \mathrm{~cm}$. A warp interlock permitted a change in the fibers from wool to cotton. Also, the number of warp yarns were increased from 212 yarns to 424 yarns to diminish the narrowing effect of a warp-faced weave. 


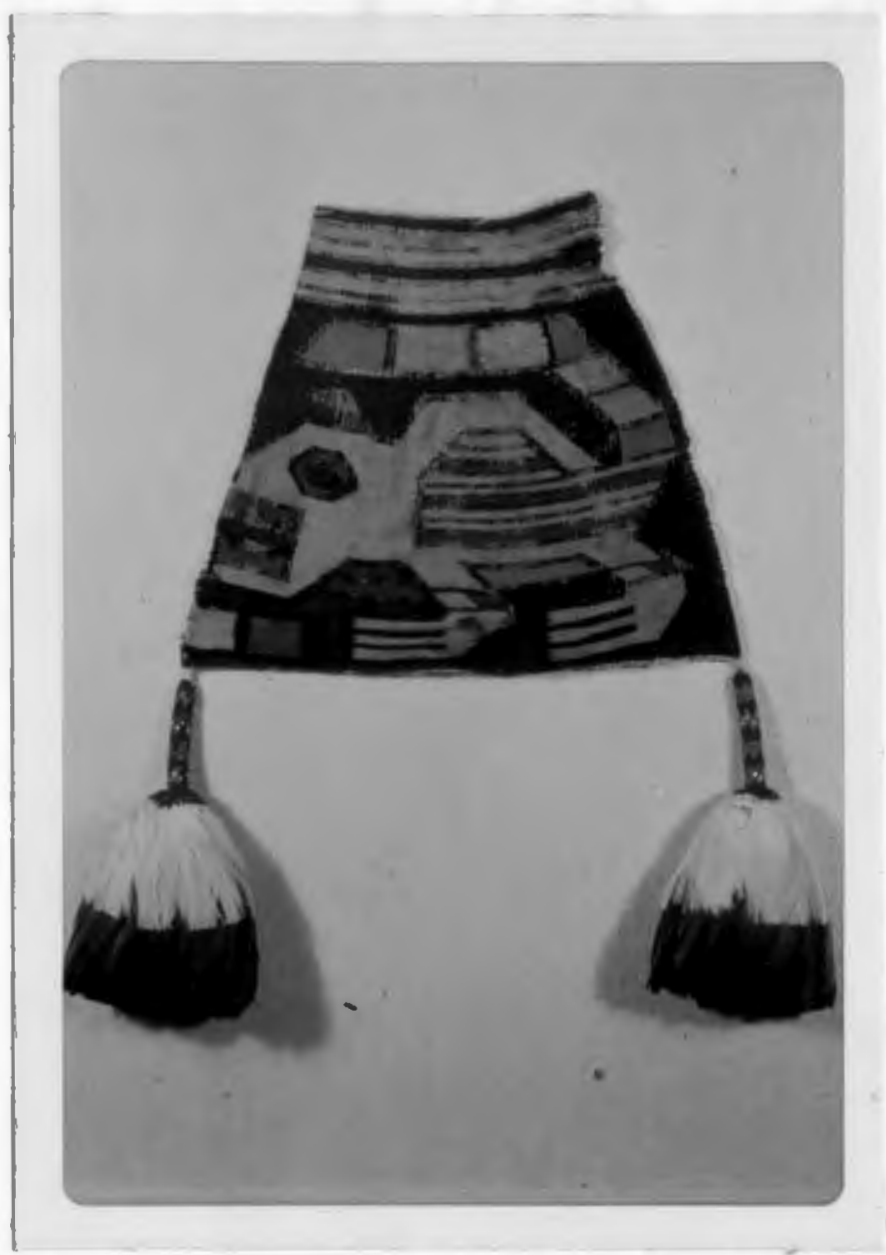

Pigure 55. Loom shaped weaving. Source: Textile Museum, Washington, D.C. \#91.148 


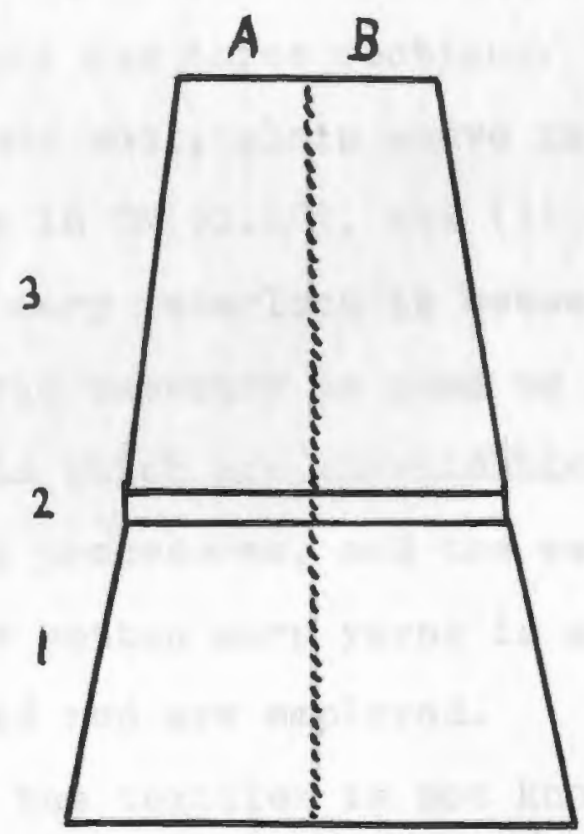

TM 91.483 and

TM 1959.209

Dimensions of Part A - TM 91.483 (90)

Complete length $-95.5 \mathrm{~cm}$

Length of tapestry portion $-41.0 \mathrm{~cm}$ Length of eccentric tapestry $-4.5 \mathrm{~cm}$ Length of warp-faced section $-50.0 \mathrm{~cm}$ Width at cotton loom end $-21.5 \mathrm{~cm}$ Width at eccentric tapestry $-32.5 \mathrm{~cm}$ (warp interlock)

Width at alpaca $100 \mathrm{~m}$ end $-42.0 \mathrm{~cm}$

Figure 56. Shaped garments. 
Both textiles consist of two approximately equal parts which are joined lengthwise with an extra warp in a dovetailed manner. Each has three sections: (1) alpaca wool, tapestry, (2) alpaca wool, plain weave in TM 1959.209, eccentric tapestry in TM 91.483, and (3) cotton, warp-faced plain weave. The warp interlock is between (I) and (2).

The eccentric tapestry is used to hide the uneven interlocking joints which are unavoidable when one considers the warping procedures, and the weaving over paired wool and quadruple cotton warp yarns is a necessity when heddle rod and shed rod are employed.

The use of the textiles is not known. Bird calls TM 91.483 "a cape shaped by expanding the warp,"91 and King leans towards the acceptance that they are cape headdresses from the Huaura Valley, Central Coast which can be tied to a headband and fall over the shoulder. 92

\section{ddition of warp yarns}

To add warp yarns to a weaving on a backstrap loom that is already in progress is more bothersome than it is to subtract warp yarns. When the addition is for the remaining length of the warp, it is easier to reverse the weaving procedure. The "added" number of yarns could be added to the initial set-up and then subtracted during the weaving process. The final products of an added and a subtracted warp are identical. 


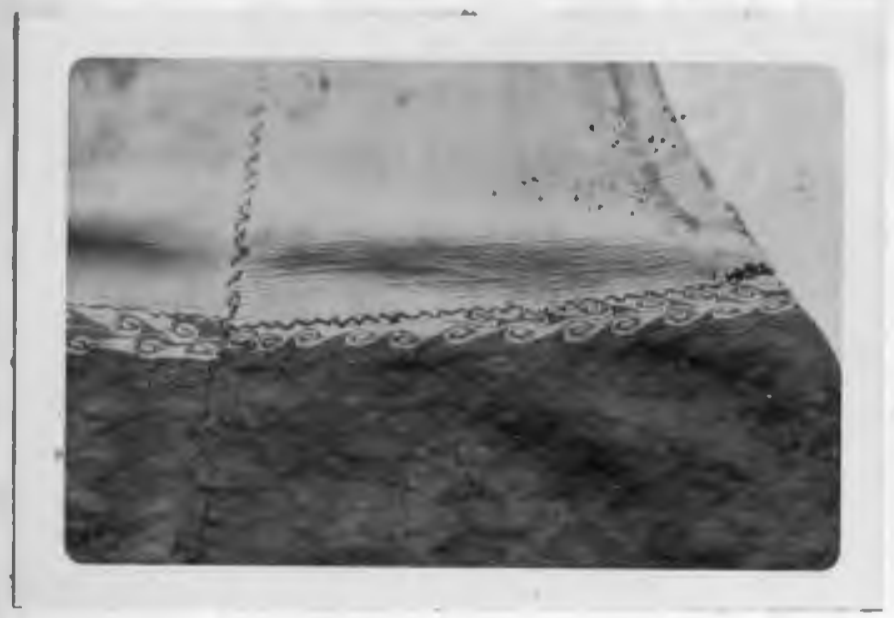

Detail of \#91.483.

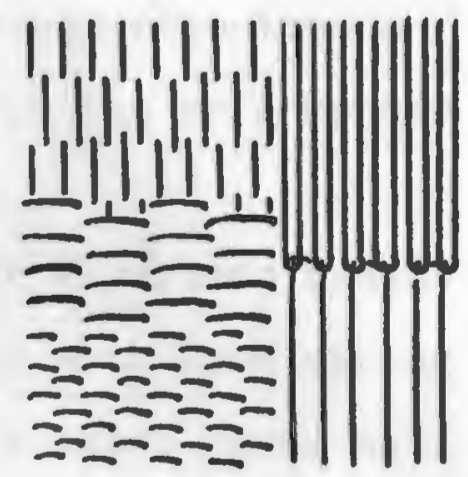

Diagram of warp interlock point. Change from plain weave to paired warp and warp-faced weave.

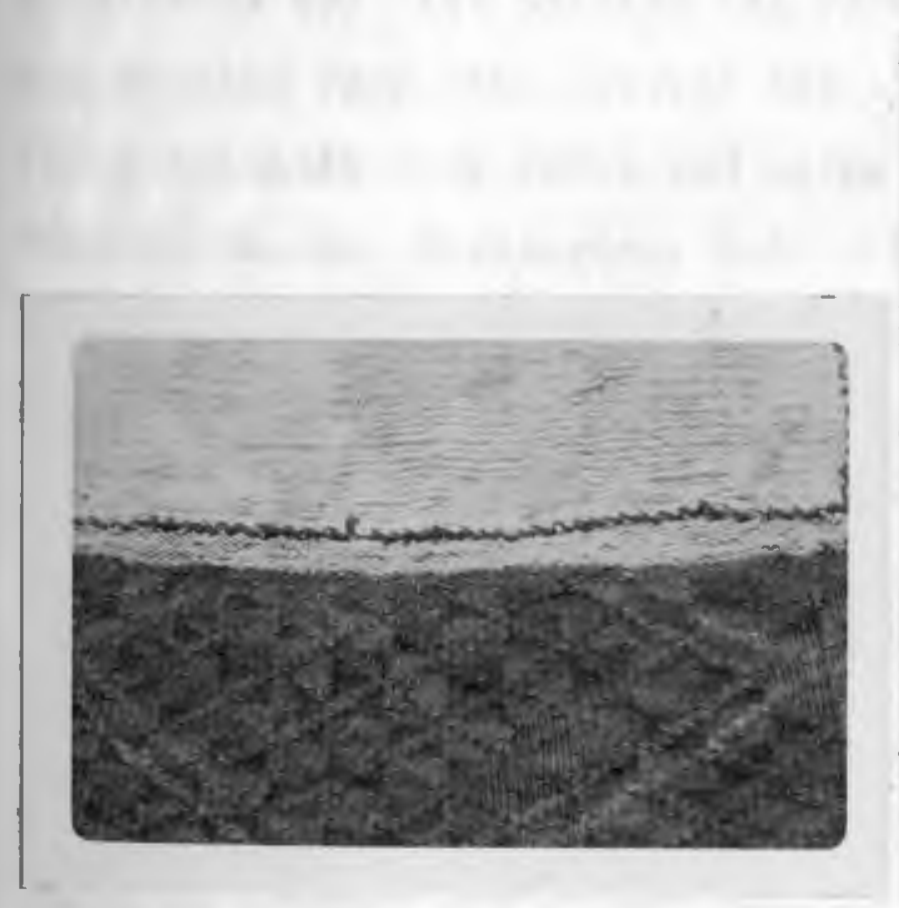

Detail of \#1959.209.

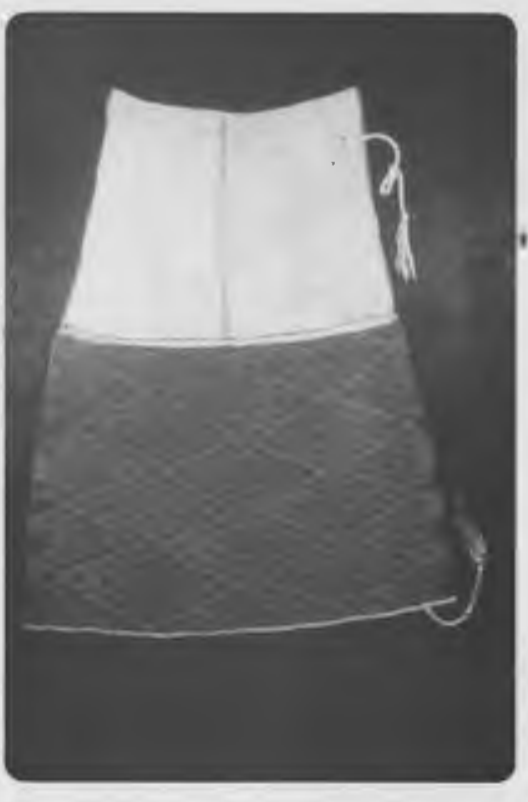

Total garment.

Figure 56. -- Continued Source: Textile Museum, Washington, D.C. 
In either case, the heading on the opposite loom bar is omitted to allow for the full freedom to fan or compress warp yarns.

Negative 331723 illustrates how the Peruvians added a few warp yarns to an already set-up warp with loom string and a few inserted wefts (Figure 57). The extra yarns had to be slipped between heading cord and lashing cord with a needle and returned to the other loom bar.

nbtraction of warp yarns

Warp yarns, once engaged in the woven web, can be eliminated by: (1) pairing the yarns and after securing the doubled yarn with several wefts to cut one of the yarns, (2) cutting.the warp yarns and using them as weft. TM 91.517, Textile Museum, Washington, D.C. - Bird writes that the tapestry bag was woven in two separate pieces and seamed at sides and bottom with a width difference of $15.8 \mathrm{~cm}$ between top and bottom. 93 (Figure 58).

Furthermore, Bird concludes that the warp set up was probably a fanned warp which is obvious when one considers the reduction of the warp yarns from 216 to 154 (minus 64) in one piece and 222 to 126 (minus 96) in the other, and compares it with the cloth count of $16 \times 68$ per $\mathrm{cm}$. The warp yarns were paired, woven as doubles and then cut. 94 


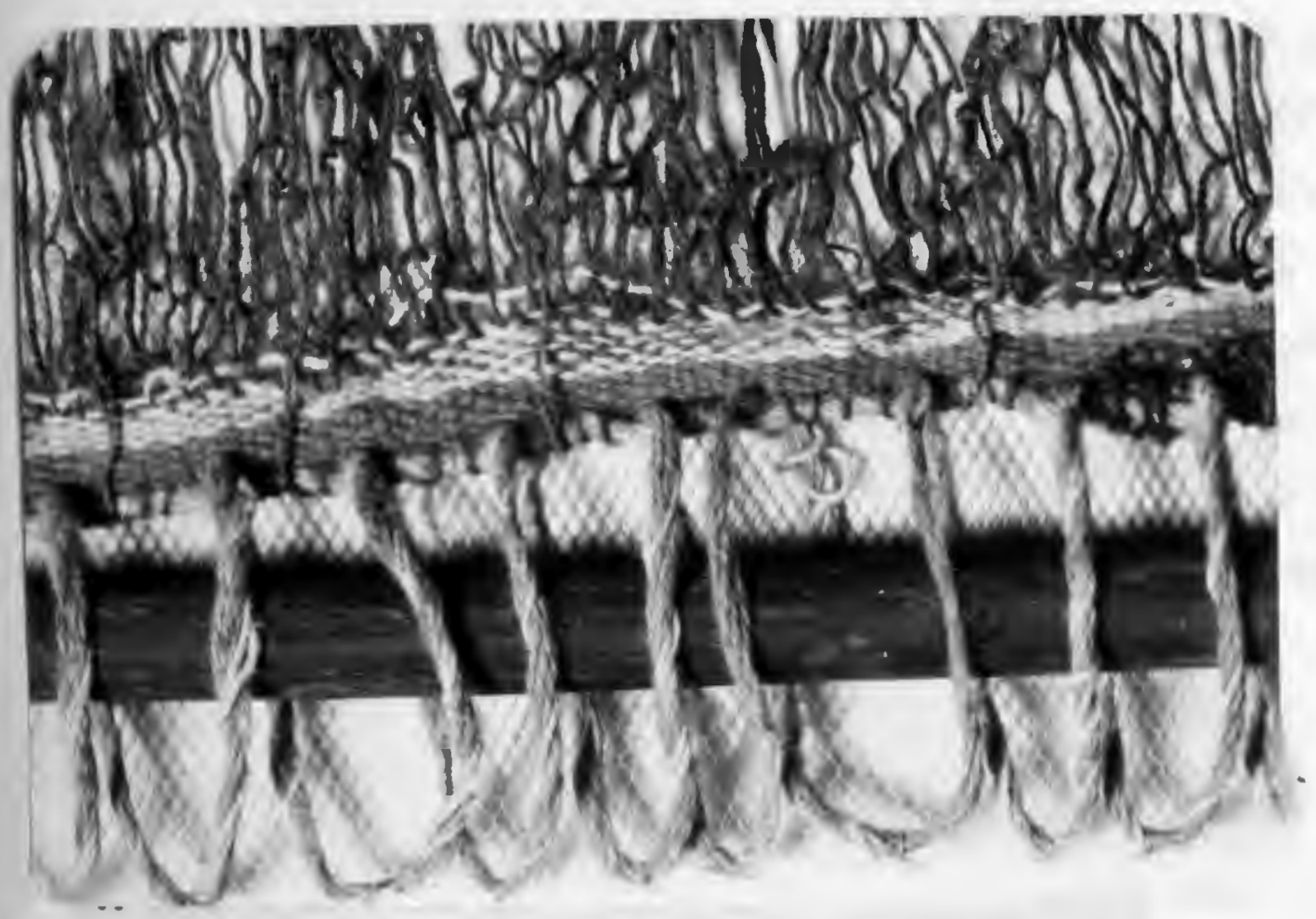

Figure 57. Addition of warp yarns.

Source: Courtesy of American Museum of Natural History. (Negative 331723).

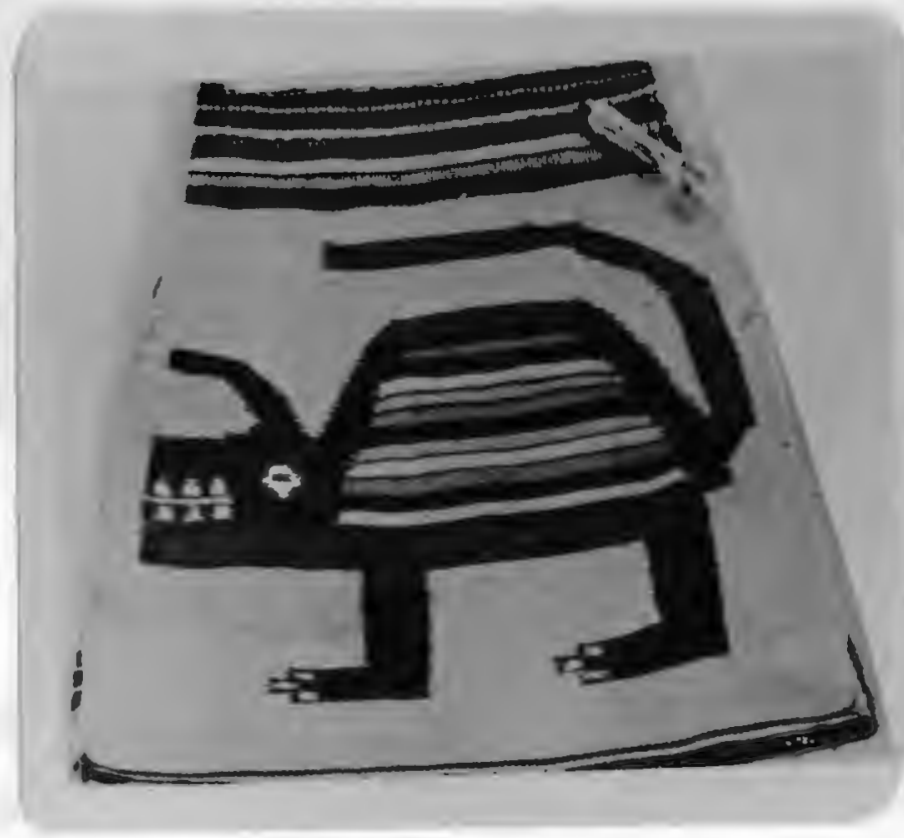

\#TM 91.517, Textile Museum

Pigure 58. Shaped weaving.

Source: Textile Museum Journal, Vol. 1, No. 3, 1964, Fig. 5. 
A technique not reported in literature but used in the experimental weaving done by a student of the author is depicted in Figure 59. A parallel warp was set up as wide as the center width of the scarf. The weaving began at the center and proceeded towards the loom bars. Each join is about two inches from the loom bar selvage. Warp yarns were reduced by cutting one warp loop at the loom bar. Then the two warp yarns were woven as wefts and became part of the design (horizontal lines). (Figure 59)

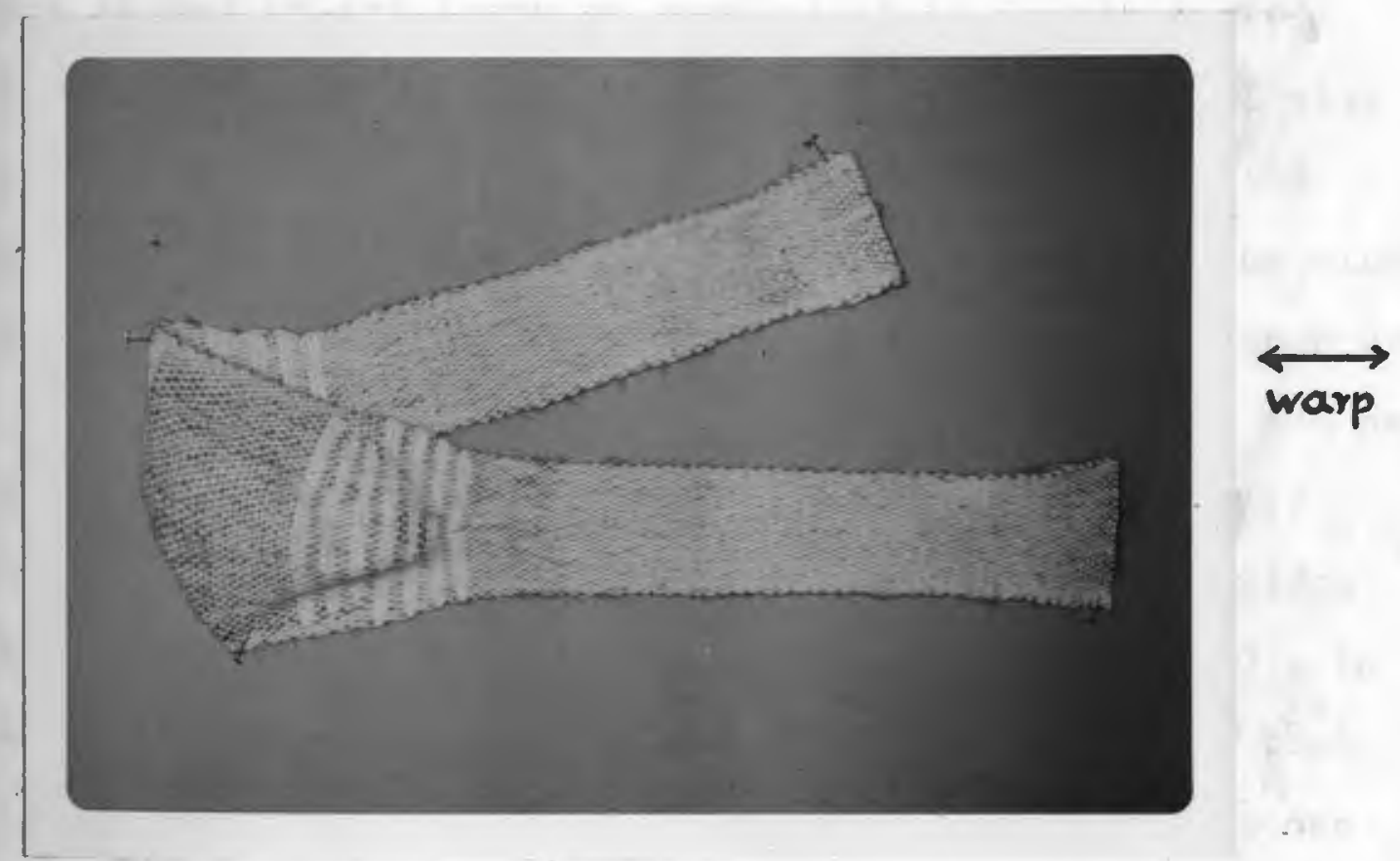

Figure 59. Shaped scarf, experimental weaving. Done by: Gail Harriman, 1973.

Pritition and subtraction of warp yarns

An addition and subtraction of shorter warp yarns to a given warp would produce a localized widening of the woven web. 
Montell describes poncho shirts with extreme width at the shoulder, up to $228 \mathrm{~cm}$, a lower width of $170 \mathrm{~cm}$, and with a length of $103 \mathrm{~cm}$. They were found in Arica and also in Chincha, and date from two periods, 900-1100 and 1100-1350 A.D.95 The American Museum of Natural History, New York, has two brown shirts - \#41.1/5402 and \#41.1/5403.

Number 41.1/5403 (Figure 60) has a shoulder width of 84 inches and a bottom width of 38 inches. The sides are seamed up and leave an opening of 14 inches and $9 \frac{1}{4}$ inches for the arms. The neck opening is a vertical slit of 8 inches deep in front. The shirt widens about $10 \frac{1}{2}$ inches from the shoulder down in front and back. The wider part would rest on the shoulder and extend to the upper arm. The shirt is woven in warp-faced plain weave and has two purple lengthwise stripes on each side as the only decoration. The bands have approximately the same width throughout the garment. The cloth count is about $60 \times 14$ in the widened section, and $80 \times 16$ in the lower section. Presumably the widening is effected through added and later subtracted warp yarns by the warp interlock technique with a regular weft. The number of warp yarns doubles which means that every four yarns has one warp loom introduced. 


\section{||||$U|||| U||||$}

Method of doubling warp number.

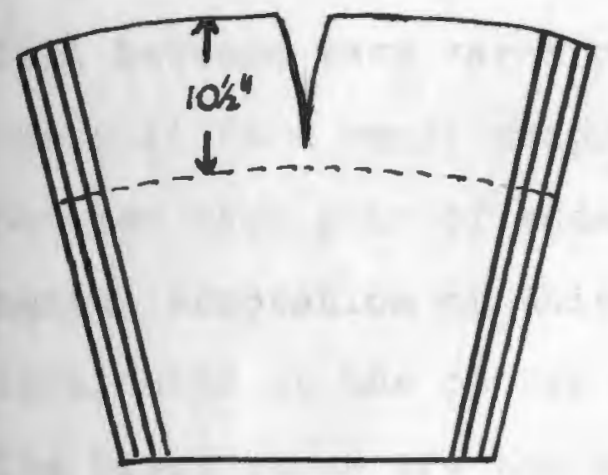

Technique of interlocking.

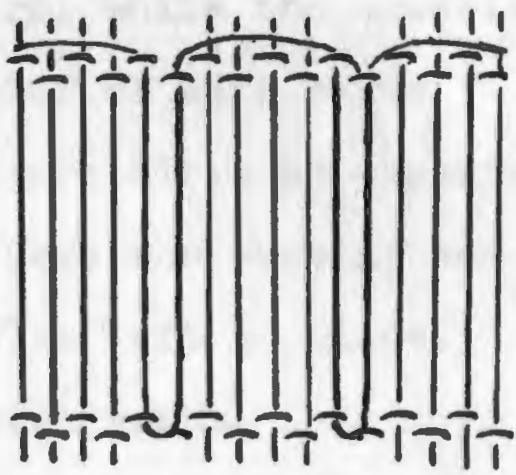

Figure 60. Arica shirt.

Source: American Museum of Natural History, New York. $\$ 41.1 / 5403$

Presumably the technique involves that a new warp setup is superimposed on the base warp which is a very simple procedure. It requires two looms, one with the regular warp and one with a shorter one. At the point where the addition should take place, the shorter loom will be centered above the base loom and fastened to the lower loom bars--or handled with a second backstrap. A new row of string heddles is formed which includes both warps. After opening the shed, the first weft will secure the warp loops of the new warp within the base warp. The loom bar of the second warp is withdrawn right after the first weft. After weaving several wefts, the loom is turned around and the same procedure locks the opposite warp loops into the base fabric. 
This technique has one limitation: since a continuous warp has alternating warp loops on the opposite loom bar, one (the first woven) set of warp loops will completely fall between warp yarns of the base warp, while the opposite one will form small skips over the number of warp yarns between each pair of added warps. Figure 61 is an experimental adaptation of this technique. Here the weaving was terminated at the center with the heddles left in place. The black yarns are the superimposed warp yarns.

The first interlock was easily identified on the specimen \#41.1/5403 during the research. Unfortunately, the second one could not be identified within the limited textile analysis although it is assumed that this type of interlock is necessary as seen by the experimental weaving. According to Rowe, it does occur among Peruvian textiles. 96 taparallel alignment of the loom bars

Any alignment of the two loom bars is possible as long as the warp tension is maintained and no warp slippage occurs. The same is true for shaped loom bars. In addition, one should also consider the shape of the beater for creating and maintaining a shaped weft. These can be considered concomporary applications; they were not encountered during the research.

change of warp and weft

Weaving with parallel and multiple loom bars and where warp yarns change into weft yarns produces nonpetangular fabrics with finished selvages. In the absence 


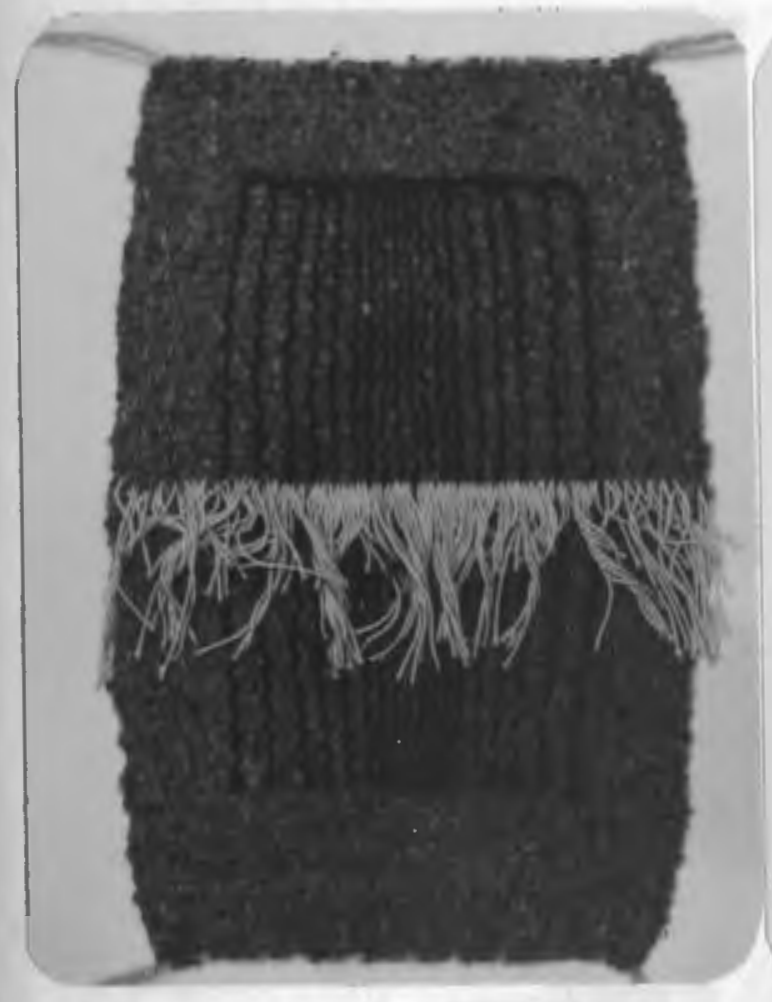

Face

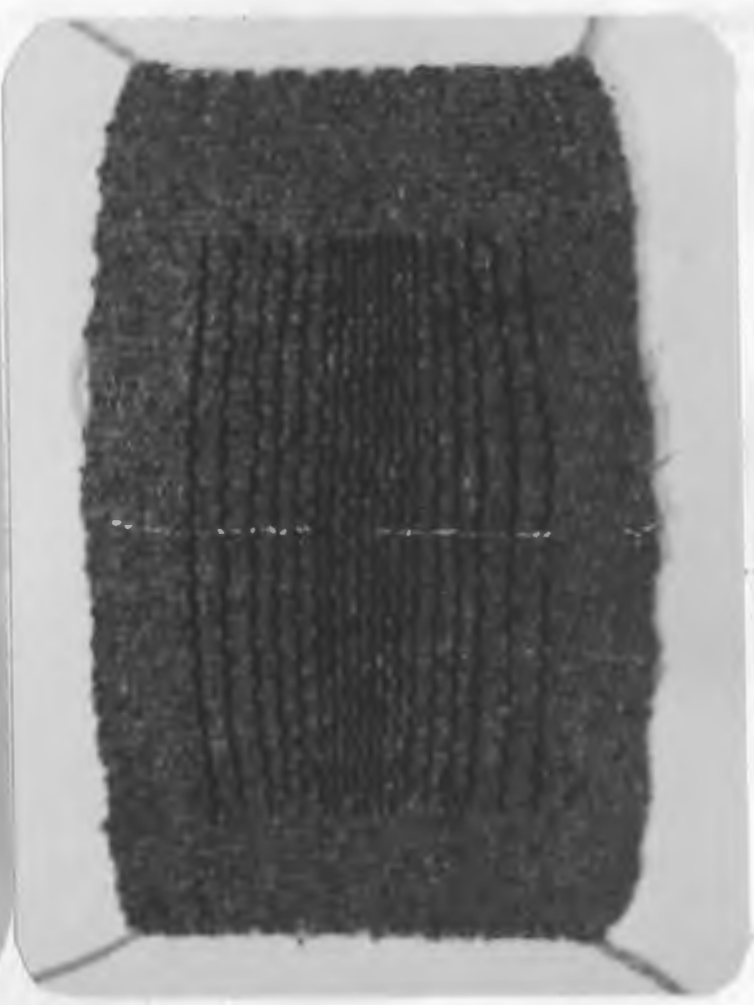

Reverse

Figure 61. Shaped weaving with superimposed warp. By author.

Note: Dimensions - width at loom bars - $5 \frac{1}{2}$ inches width at center -7 inches length - 10 inches 
of a Peruvian sample the ethnological Mexican loom, \#65-5159, American Museum of Natural History, clearly illustrates this application of loom shaping. The end product is half of a guechquemitl, a shoulder covering worn by Otomi Indian women.

- . to produce the desired shape, narrower at one end than the other and with one side curved, an additional set of yarns is attached to one of the loom bars. These are turned in succession and entered as weft after which they function as warps.97 (Figure 62)

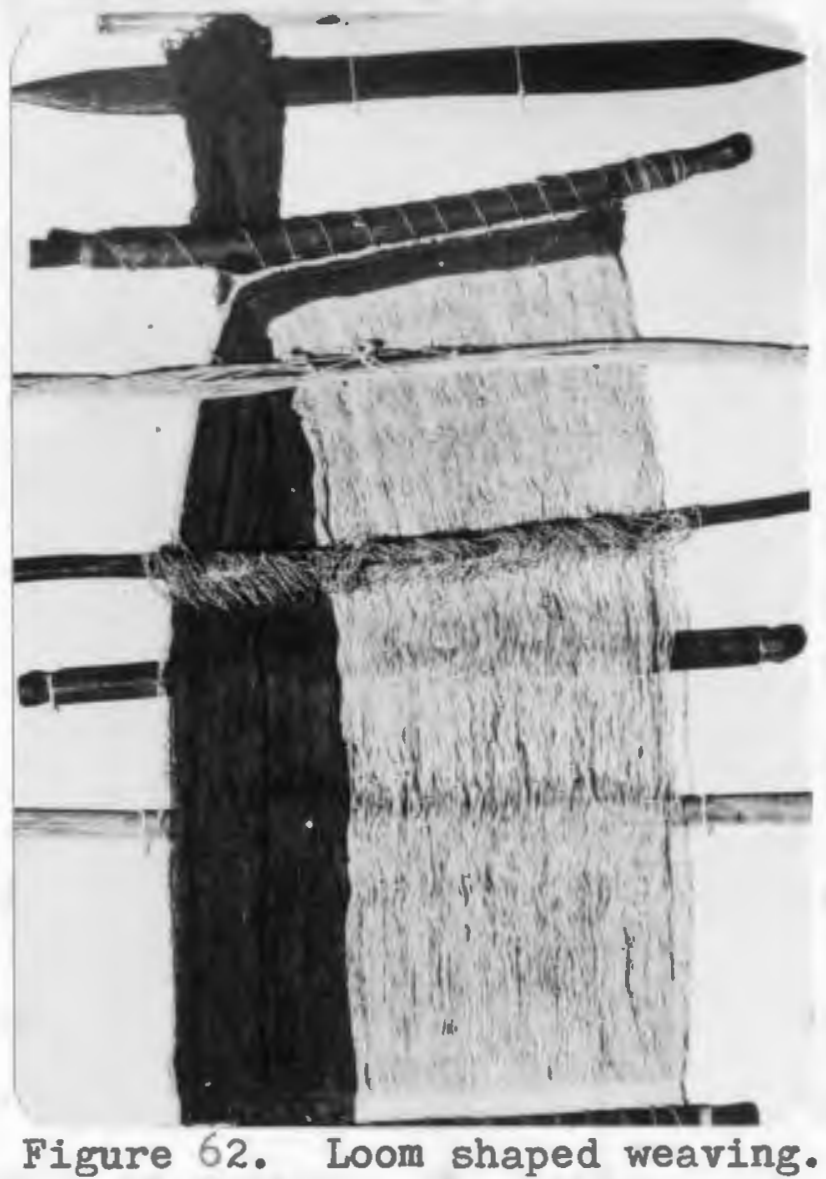

Source: American Museum of Natural History, New York. \#65-5159. 
Oddities in loom shaping

An interesting loom shaped textile with the caption "an unusual Tiahuanaco style shirt, shaped in weaving, polychrome tapestry," is featured in The Fabrics of Peru. 98 (Figure 63)

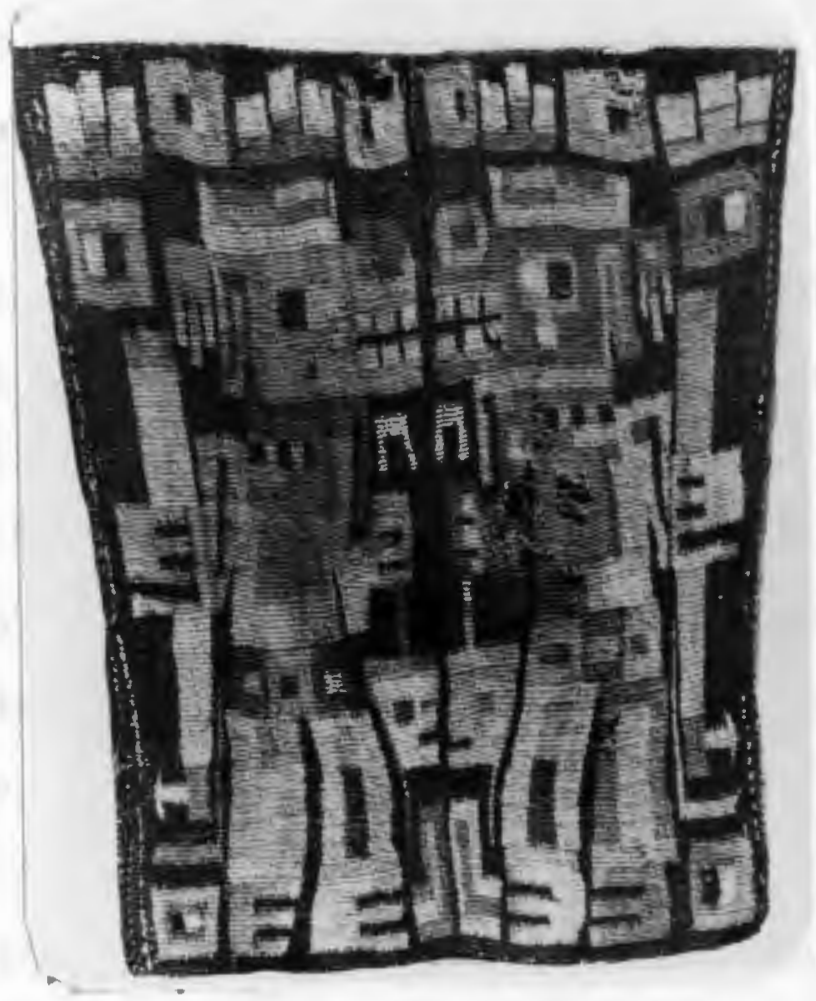

Figure 63. Loom shaped tapestry shirt.

Van Stan's additional information on this article based on seeing this garment on a display in Lima, but without being able to research it, raises some questions. - . I believe scaffolding wefts must have been used to hold warp loops along the neck opening. The warps along the sides of the garment appear to have been cut and the ends turned back into the fabric... but . . there are heavier yarns along the bottom edge of the shirt which aggear to be loom string or heading cords . . . 99 
According to Sawyer, the large tapestry shirts of the Tlahuanaco period were made on a large loom with a short warp and in weft interlocked tapestry. ${ }^{100}$ It appears to be in the dovetail technique. Then, definitely, the loom bars were not parallel and the shaping was a simple matter. The heavy loom strings could be heavy end warps. But the disintegrated "warp yarns" in non-black areas and the intact "weft yarns" seem to be puzzling.

Van Stan reports on other oddities ${ }^{101}$ which clearly demonstrate the versatility of the backstrap loom based on the absence of the reed, on the simplicity of the set-up whereby loom bars are added, or rearranged during the weaving. The applications produce woven-in pockets across the weft or partially across the weft, woven-in warp fringes, and woven closures of pouches at the bottom. Technically, these oddities have a simple explanation.

The pieces are six small bags from Ica, with an average depth of 8 inches, and 5 inches wide at the mouth and $63 / 4$ inches at the bottom. All are woven in warp-faced plain weave except for one which is patterned. They have fringes on the bottom, and five have pockets across the width which open to the inside of the bag. Only one has two pockets with a plain section without pockets.

The weaving of pockets which are horizontally arranged is done in slit tapestry and the pockets are formed and sewn up after the weaving is completed. The weaving of two pockets 
on one side only and a plain woven section between the pockets requires two warp set-ups on three loom bars. The pockets are woven separately and the weaving is then combined (Figure 64).

The woven closure at the bottom is produced by weaving the two bag sections, then after folding the backstrap loom in half, inserting at least three wefts through the combined warp yarns (Figure 64).

The other closure, which involves warp fringes is woven by separating the plain weave warp into the alternating sheds. Then the shed roll is moved behind the warp with the alternating yarns and tied parallel to the upper loom bar. Now with tension on the warp, the heddle rod is tied in the same manner to the lower bar which will produce a fringe of equal length to the one on the shed rod. Then the wefts are inserted between the fringes (Figure 65). Gauze

Gauze refers to the crossing of warp yarns and securing the cross with a weft. There are simple and complex gauze weaves. The plain $1 / 1$ gauze involves two steps: the crossing of two adjacent warp yarns and the return to the priginal position. The cross can be established with hand manipulation and pick-up stick. The return is accomplished with the regular shedding devices--without hand manipulation. O'Neale groups the gauze structures found in the Peruvian textiles into four types: I, II, III, and IV. 102 (Pigure 65). 


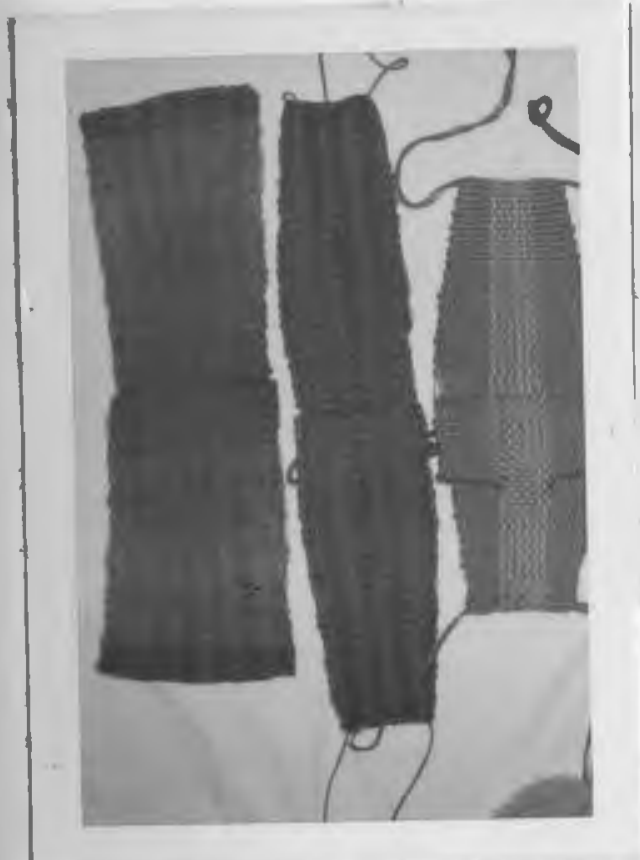

Weaving of pockets, shaping, woven closure.

Bags are open, unsewn on sides.

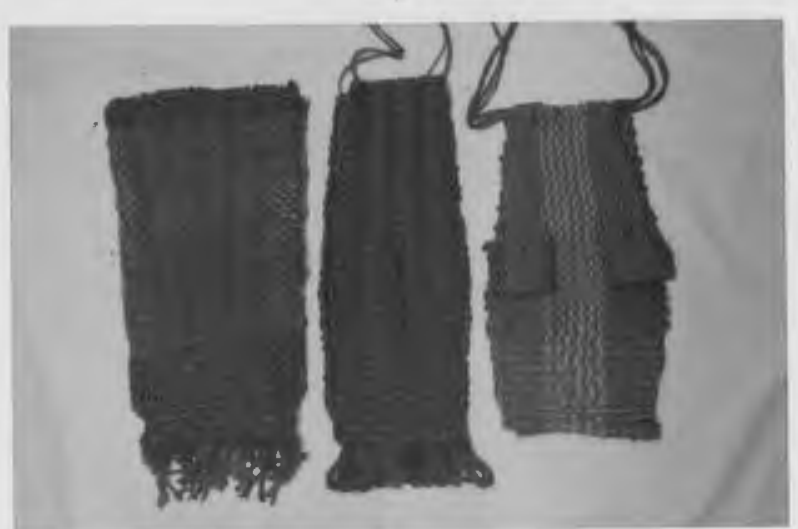

Bags are closed, woven closure.

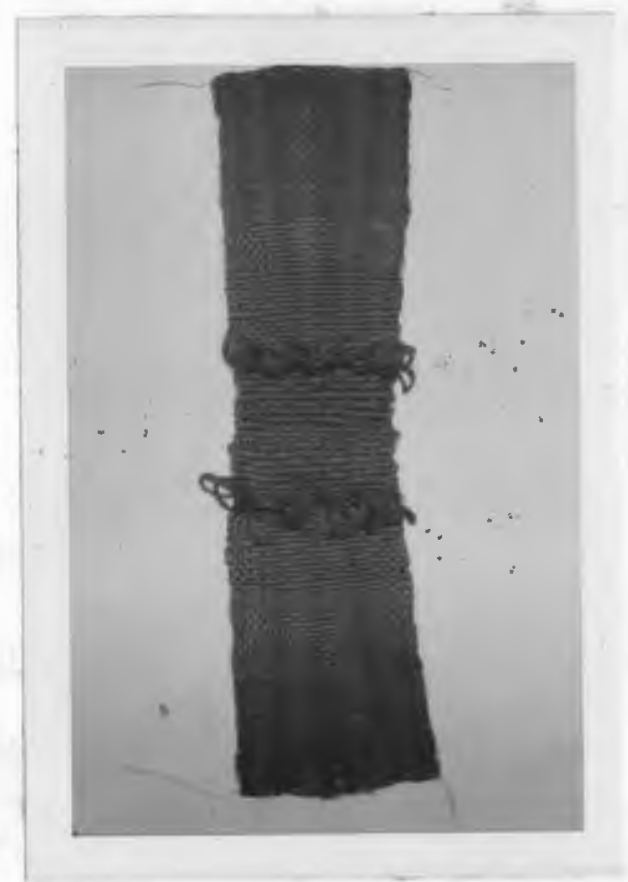

Warp fringes and woven closure.

Figures 64: Experimental weavings. By author. 
I. Plain gauze, the same two warp yarns are crossed.

Appearance: vertical bars.

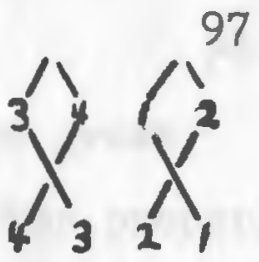

II. Plain alternating gauze. Appearance: net-like.

III. Plain gauze with paired warps.

Appearance: vertical bars.

(a)
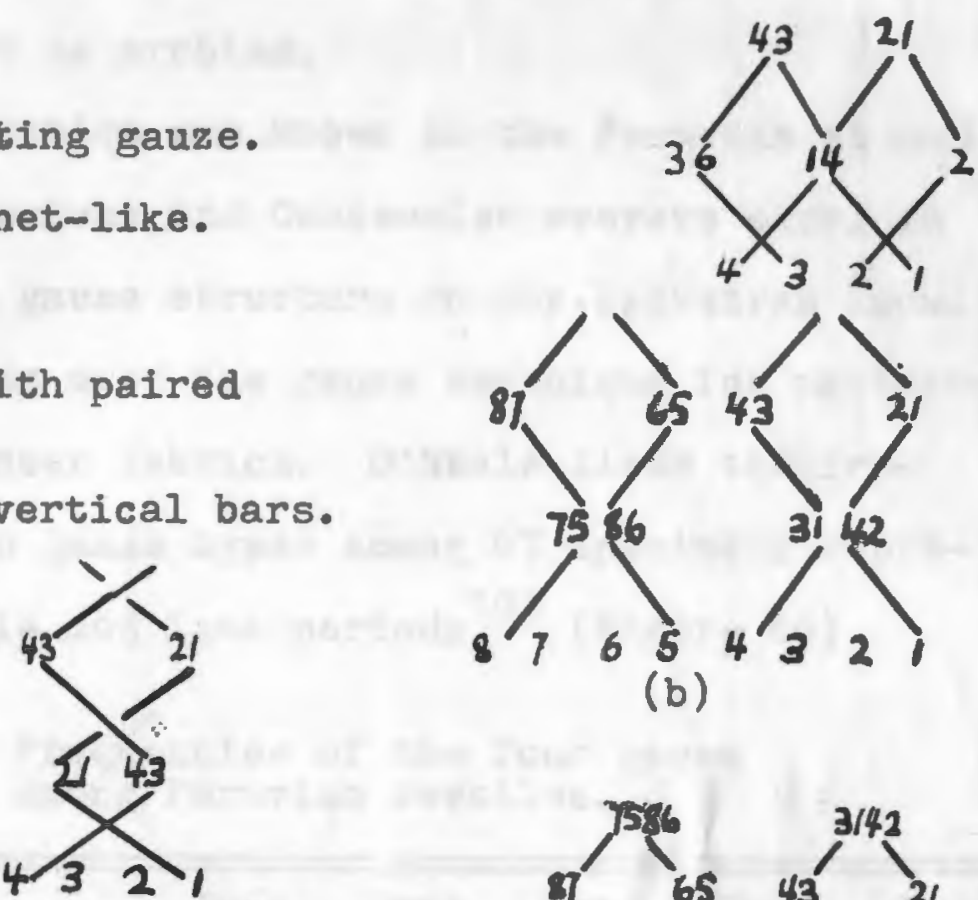

V. Complex alternating gauze. Appearance: net-like.

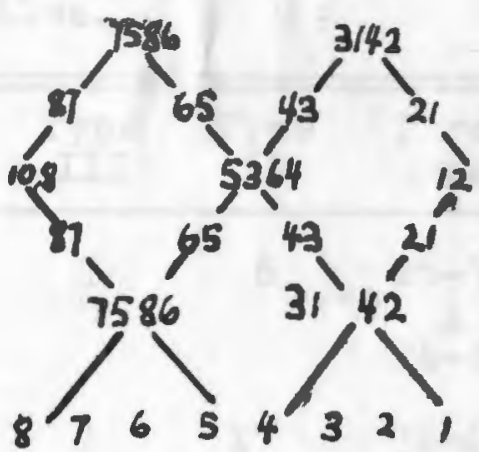

Figure 65. Types of gauze.

On the harness loom the techniques have to be manipulated with fingers and pick-up stick. Beads and doups can mechanize the loom to some degree, but the design potential is limited to plain gauze. The reed and the vertical arrangement of the heddles in the harness frame are the restricting factors. 
On the contrary, the backstrap loom offers great possibilities. The flexible heddle loops can, when properly laced, cross the warp yarns. And since the reed is absent-alternating gauze is no problem.

Gauze construction was known to the Peruvian at early times. And today Mexican and Guatemalan weavers excel in weaving complicated gauze structure on the backstrap loom. The ancient Peruvians used the gauze technique for patterning and for plain sheer fabrics. O'Neale lists the frequencies of the four gauze types among 67 specimens representing early, middle and late periods 103 (Figure 66).

Figure 66. Frequencies of the four gauze types among Peruvian textiles.

\begin{tabular}{|c|c|c|c|c|c|c|c|}
\hline Period & No & Occurrence & Type & $\begin{array}{l}\text { Type } \\
\text { II }\end{array}$ & $\begin{array}{l}\text { Type } \\
\text { III }\end{array}$ & $\begin{array}{c}\text { Type } \\
\text { IV }\end{array}$ & $\begin{array}{l}\text { Thread } \\
\text { count }\end{array}$ \\
\hline Early & 7 & 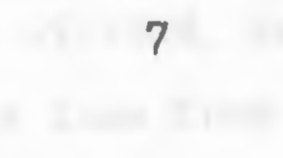 & & & 1 & 6 & $\begin{array}{c}26-30 \\
x \\
24-28\end{array}$ \\
\hline Middle & 21 & 23 & 4 & & 1 & 17 & $\begin{array}{c}36-40 \\
x \\
36-40\end{array}$ \\
\hline Late & 39 & 43 & 9 & 7 & 4 & 25 & $\begin{array}{c}20-84 \\
x \\
16-24\end{array}$ \\
\hline
\end{tabular}

Type IV had the highest frequencies and appeared at the Early Period. O'Neale called this type the Peruvian gauze $\mathrm{O}^{104}$ and King the Paracas variety."105 The thread counts increase in number and range from the Early to the Late Period. 
The Peruvians, ingenious in exploiting particular techniques used the gauze structures, for example: (1) patterning utilizing the contrast between open and compact areas (\#TM 1969.392), (2) for emphasizing an allover design (\#51.2458), and structurally in the change from paired warp in the tapestry weave to plain weave probably to separate the paired warps in the absence of a reed (\#TM 91.378) (Figures67-69).

But how did they weave the gauze weaves? Many of the pattern applications, especially when they involve variations within the textile, have to be executed by finger manipulation. Did they use leno heddles for weaving allover gauze with a high cloth count and a small repetitive structure like the plain gauze in \#51.2458 with a cloth count of 16 paired warps $\times 12$ wefts per inch?

Number 65/5808, American Museum of Natural History, New York, is a loom from Zacatipan, Mexico which displays four warp control systems with a total of 20 string heddle rods. The loom is set up to weave plain weave, plain gauze, complex alternating gauze in horizontal bands and in sections. The warp control for plain alternating gauze is as follows (Figure 70):

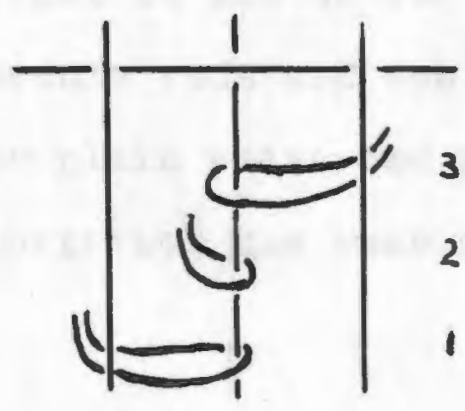

Shed rod

Heddle rods 
(1) For plain weave alternate heddle rod 2 and shed rod

(2) For alternate gauze weave heddle rod 1 and shed rod and heddle rod 3 and shed rod

Figure 70. Warp control for plain alternating gauze.

The four groups of heddle rods consist of $5,8,3$, and 4 heddle rods. The loops are two inches long. The four shed rods which are inserted into the warp are always under the same yarns. This is a necessity when several heddle rod groups are placed in the warp. Only one of the shed rods can be active at the time of the weaving.

To make the heddle arrangement, the first crossing of the warp yarns is done manually and placed on the pickup stick. Then the continuous string heddle cord is taken through the open shed formed by the pick-up stick and the heddles are laced.

Number 41.2/5479, American Museum of Natural History, New York, has a loom that is set up for gauze weaving. The loom has two string heddle rods and one shed rod. The warp control is planned for plain weave and plain gauze. The Mnfinished fabric illustrates the weaving of tapestry 


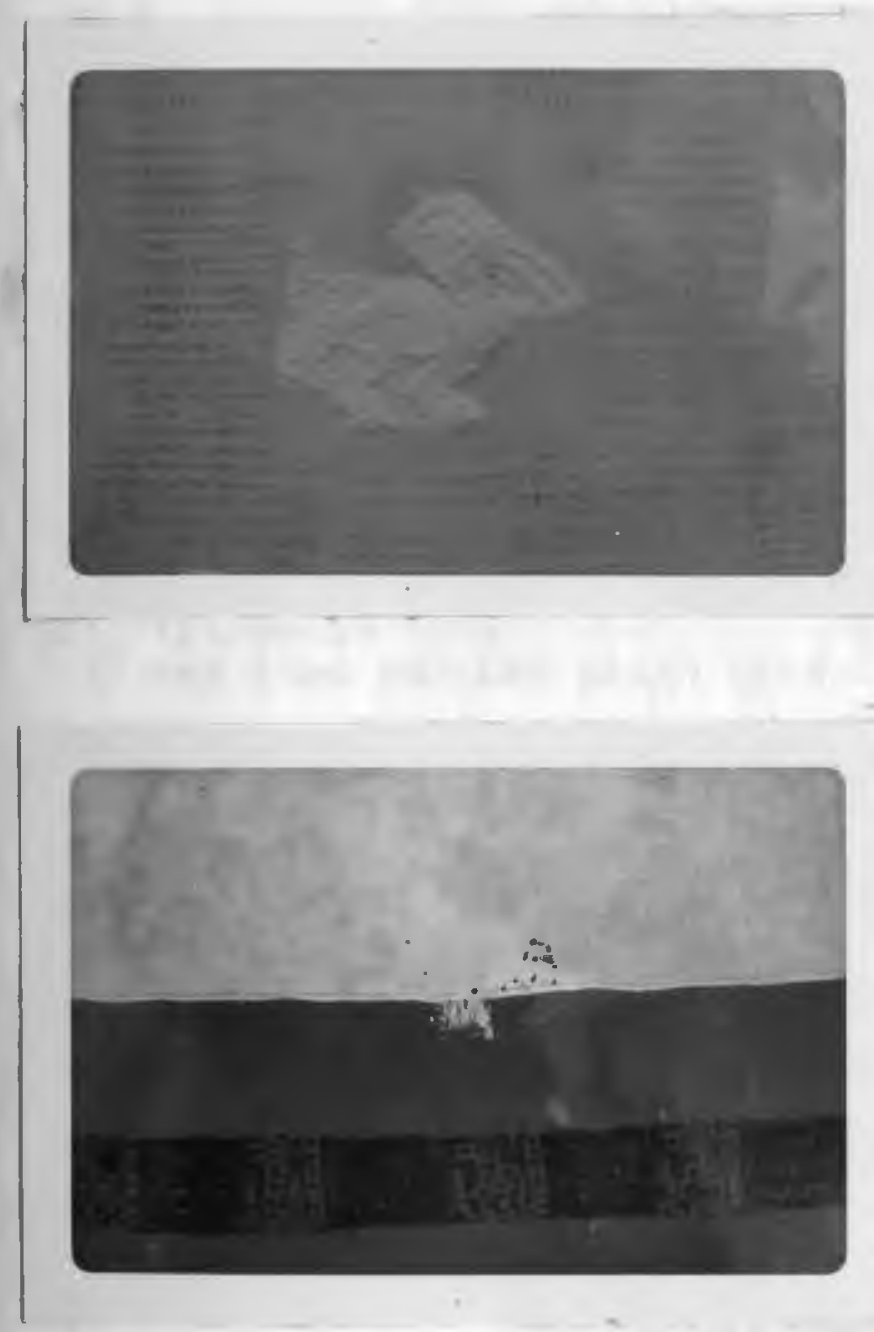

Figure 67. Plain weave with gauze.

Source: Textile Museum. \#1969.392.

Figure 68. Breech cloth. Source: Textile Museum. \#91.378.

Note: Warp yarns cross at junction between square count and weft-faced areas.

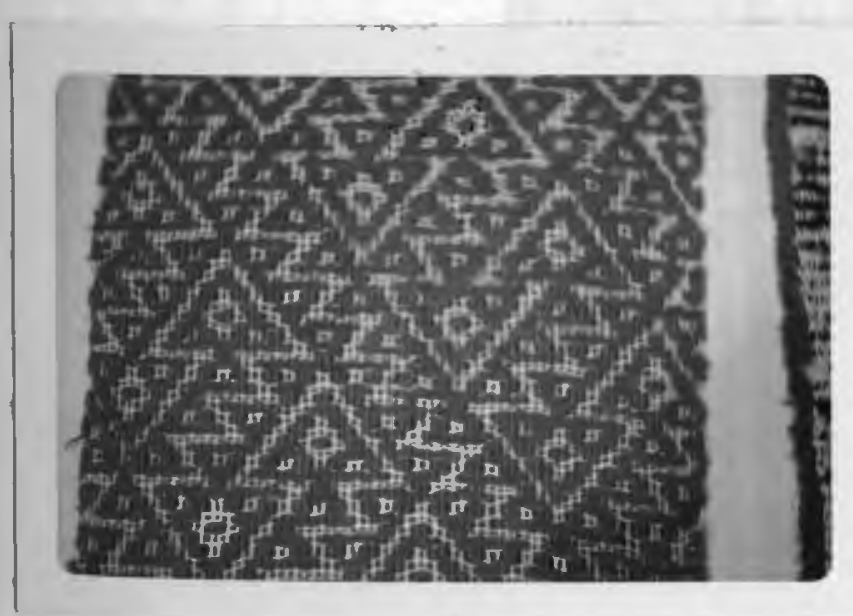

Figure 69. Tapestry technique on gauze.

Source: Museum of Fine Arts, Boston, Masschusetts.

Note: South or Central Coast area. Late or Intermediate Period. \#51.2458. 
on a gauze backgnound. There is no heavy heading cord or weft. A plain weave heading is followed by a row of plain gauze before the design commences in the tapestry technique (Figure 71).

(1) Alternate heddle rod 1 and shed rod for plain weave.

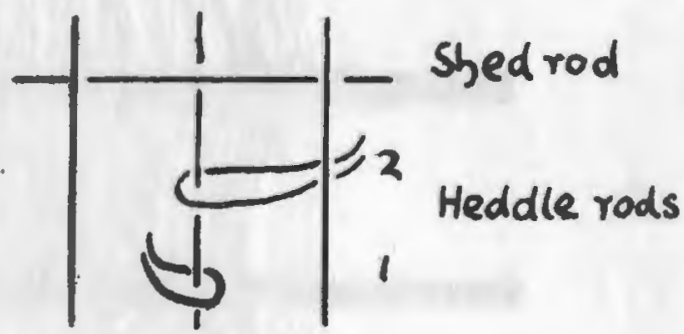

(2) Alternate heddle rod and shed rod for plain gauze.

Figure 71. Warp control for plain gauze.

Number 51.2458, Museum of Fine Arts, Boston, probably was woven in the same manner with a loom controlled gauze. The fabric is presumably from the South or Central coast from the Late Intermediate Period. Here again the weaving started out with a row of plain gauze (Figure 69).

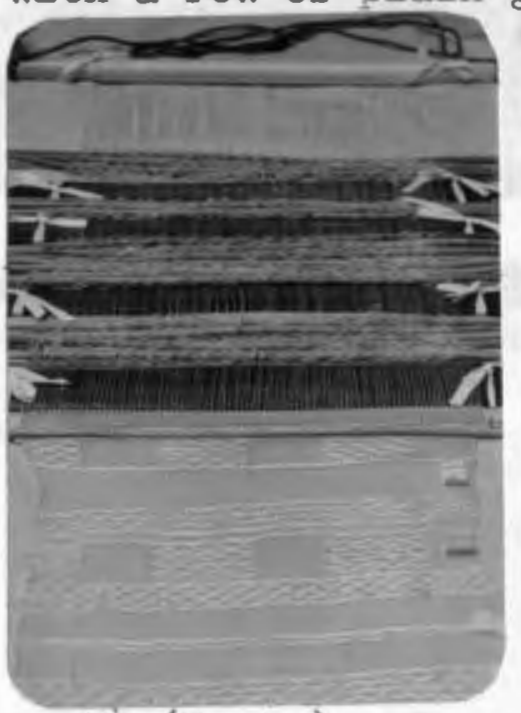

- Figure 70 (Cont.). Loom with gauze.

Source: American Museum of Natural History. \#65-5808. (Patterned gauze, Mexico) 


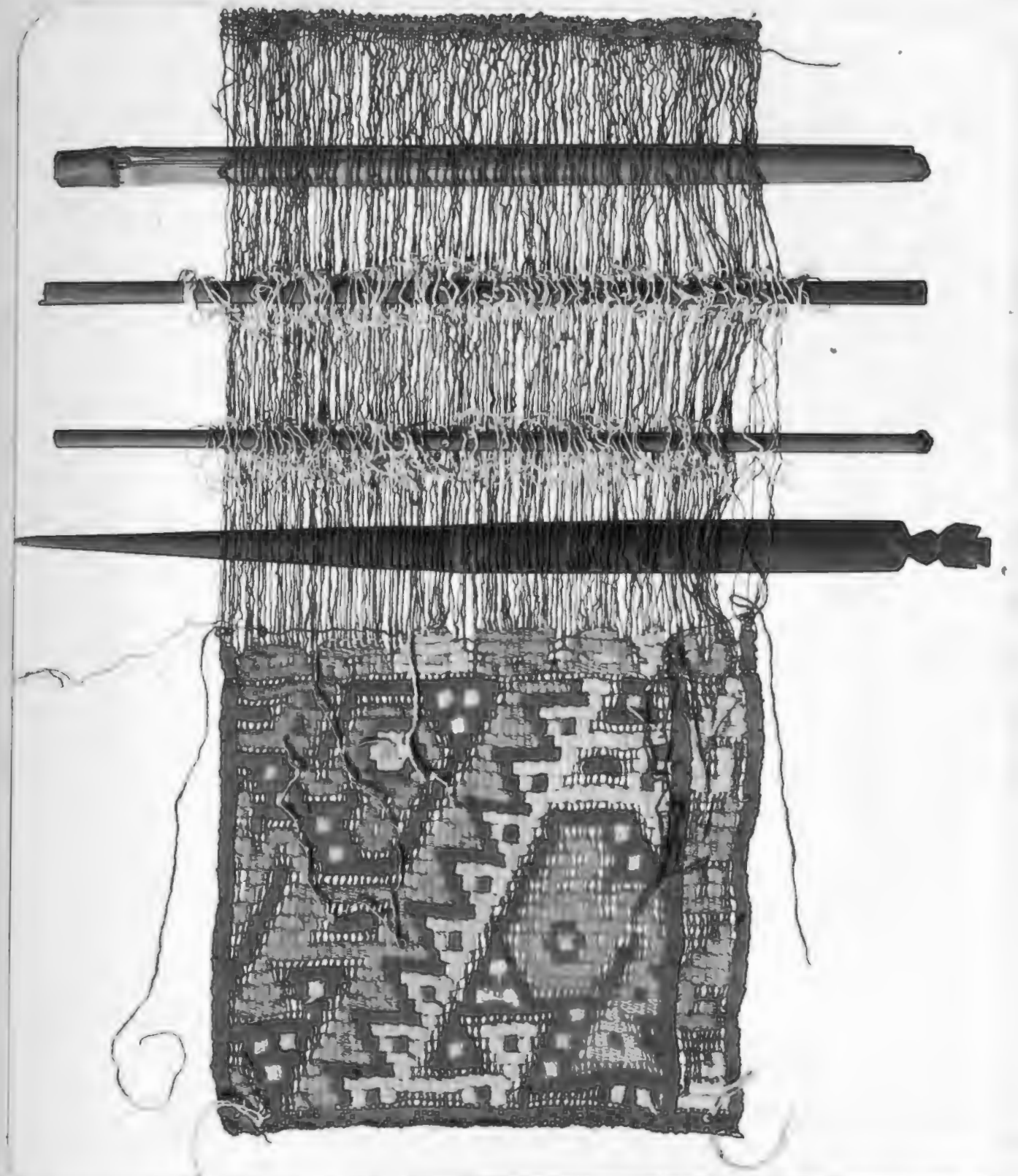

Figure 71. Chancay Valley tapestry on gauze. Source: Courtesy of American Museum of Natural History. $\# 41.2 / 5479$. 
The backstrap loom is an ideal tool for weaving gauze. Two or three heddle rods, with the shed rod positioned in the warp, are necessary for weaving alternating plain and complex gauze.

Alternating plain gauze can be produced with two different heddle arrangements (Figure 71). In one arrangement the warp yarn 3 is either pulled under warp yarn 4 or 2 after one row of plain gauze, while in the other the warp yarn 1 is pulled under yarn 4 and then returned to the original position. Alternating complex gauze can be woven by arranging two warp yarns in one heddle (Figure 72 ). Here the yarns 1 and 3 are pulled under 2 and 4, and returned to the original position. Then 3 and 5 are pulled under 4 and 6 and returned.

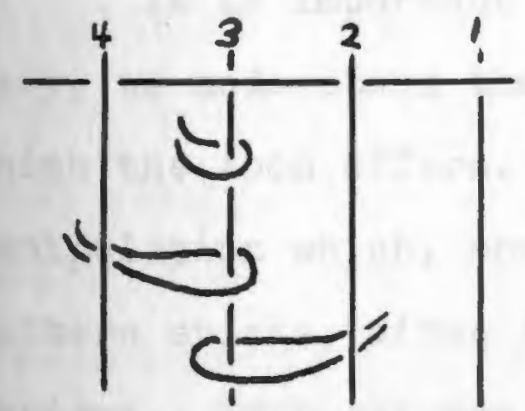

Plain gauzer-

Alternating plain gauze.

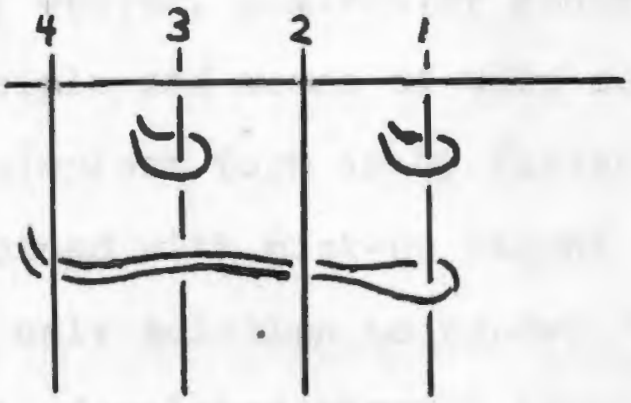

Alternating plain gauze.

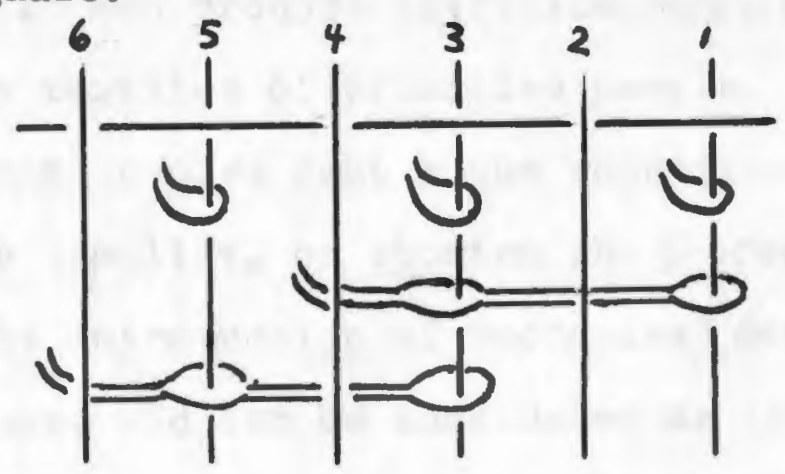

Alternating

complex gauze,

Tigure 71 (Cont.). Warp control of plain, alternating plain and complex gauze. 


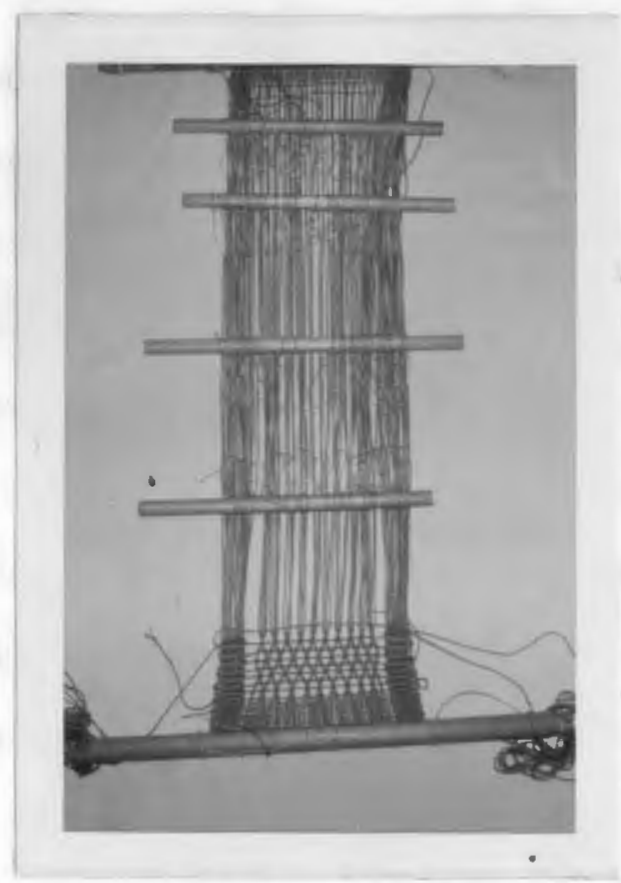

Figure 72. Experimental weaving of gauze. By author.

\section{Heddle System}

It is important to any weaver, ancient or contemporary, to understand the principle and means of warp control which the loom offers. The simplest form is by finger manipulation which, when combined with pick-up sticks or pattern sticks, often is the only solution to render free designs. With extreme skills, developed through long traditions in weaving, it can produce intricate textiles as it is evidenced by many textiles of primitive people.

Warp controls that involve continuous repetition

will lead to efforts to simplify, or shorten the procedure and thus may lead to the introduction of mechanical devices. The string heddle and shed rod can be considered as the first device to simplify the weaving of plain weave. It made its appearance about 2000 B.C. in Egypt and 1200 B.C. in Peru. 
From there would come the weaving with more than two warp divisions, thus leading to multiple heddles. And this opens up indefinite possibilities for weaving.

The question is now how many heddle rods can be used effectively with ease at one time on a warp that it can be judged improvement over finger manipulation.

In search for an answer one has to realize that the woven product is the end result of the interaction of the string heddle arrangement on the individual heddle rods, the combination of the heddle rods, and the sequence of how the heddle rods are raised. While weaving on the harness treadle loom generally utilizes a simple threading draft and thrives on combining the harnesses in the most possible ways, weaving on the backstrap loom seems to be restricted to lifting only one and not more than two heddle rods simultaneously. Therefore, the threading becomes a weave draft. The warp control for each heddle rod is either planned on the warping board or developed on the stretched warp from the usual figure eight division or developed with the wefts of the first repeat of the design. Twill

Twill is a float weave "characterized by progressive succession of floats in diagonal alignment in weft" or warp. 106 It is a basic weave like plain weave and satin, though satin is derived from the twill. 
In its simplest form, the floats are over two and under one yarn $(2 / 1$ or $1 / 2)$. The most common forms are the $2 / 2$ twill with even float lengths on face and reverse of the fabric, and the $3 / 1$ or $1 / 2$ twill with uneven floats. The latter, when combined in one weft line, becomes a turned twill and lends itself to pattern design.

The direction of the twill lines is determined by the threading of the warp yarns and the weft sequence. Continuous lines may lead to the right or left. These twills are threaded and woven in a constant sequence. Reversed diagonal lines, as vertical herringbone, are based on a reversed threading and a continuous weft sequence. Reversed diagonal lines, as horizontal herringbone, are based on a continuous threading and a reversed weft sequence. Diamond twills are a combination of both, and a broken twill features broken diagonal lines which are based correspondingly on the weft sequence or threading. An extension of the twill weave leads to two and multi-colored effects which in a weftfaced twill can yield a poly-chromatic effect or a brocaded effect.

The twill weave is known by most cultures. Among the users of the backstrap loom today are the people of Nepal, Mexico, the Southwest American Indians and little by the Peruvians. Ancient Peruvian twill textiles are rare in museum collections and very little is written about these pieces. Most of the twill textiles come from the North Coast 
where the preservation is limited. Twills were often found in refuse piles and "perhaps more twill was woven than has been assumed." 107 Bird reports that 6.6 percent of the Callinazo fabrics and 28.4 percent of the smaller Mochica (Huancaco) fabrics were of twill weave, and some were made in single-ply herringbone twill. 108 The most thorough report was written by 0 'Neale who found, among several thousands of Peruvian textiles over many years, only 17 nonochromatic textiles with a twill structure. 109 Eight of the textiles came from the Mochica area, one from Chancay, two from Canete, one from Ancon, four from the Lima area and one from the Nazca valley. Their distribution to period and structure is as follows:

Figure 73: Distribution of twill weave to period.

\begin{tabular}{|c|c|c|c|c|c|c|}
\hline Type & $\begin{array}{l}\text { Early } \\
\text { No. }\end{array}$ & $\begin{array}{l}\text { Period } \\
\text { Type }\end{array}$ & $\begin{array}{l}\text { Middle } \\
\text { No. }\end{array}$ & $\begin{array}{l}\text { Period } \\
\text { Type }\end{array}$ & $\begin{array}{l}\text { Late } \\
\text { No. }\end{array}$ & $\begin{array}{l}\text { Period } \\
\text { Type }\end{array}$ \\
\hline $\begin{array}{l}\text { Continuous } \\
\text { twill }\end{array}$ & $\begin{array}{l}4 \\
1\end{array}$ & $\begin{array}{l}2 / 2 \\
4 / 4\end{array}$ & 0 & & $\frac{1}{2}$ & $\begin{array}{l}1 / 2 \\
1 / 2\end{array}$ \\
\hline $\begin{array}{l}\text { Vertical } \\
\text { Ferringbone }\end{array}$ & 1 & $2 / 2$ & 2 & $2 / 2$ & 2 & $2 / 2$ \\
\hline Turned twill & 2 & $3 / 1-1 / 3$ & 0 & & 3 & $3 / 1-1 / 3$ \\
\hline
\end{tabular}

The earlier textiles are of cotton, the ones of the Middle and Late Periods are of wool or wool weft with cotton warp. Only fragments, the sizes range from 1 square inch to 3" $x$ 5" for the early specimen, to $26^{\prime \prime} \times 10^{\prime \prime}$ for the Late Period, and 38" $\times 18^{\prime \prime}$ for the Middle Period. Only four 
specimens are woven in all twill, all the others combine twill with plain weave or figured twill. And of the four all vertical herringbone twills, two are based on a broken twill. The warp counts range from $24-96$ and the weft counts from $12-88$ per inch. 110

Twill can be woven with pick-up sticks or by finger manipulation as the Cashinana Indians do today (Figure 74). Here, with widely spaced warps and paired warps the twill successions are easily followed.

Only if one considers the high warp count, one wonders if the weaver did not search for a more efficient solution. O'Neale thinks they did and

- . since the Early Period clothes surpass in terms of technical proficiency most of the weaving produced by today's weavers on backstrap looms, it does not seem unwarranted to credit the Peruvian with the use of the multi-heddle device.11l

About today's weaving $O^{\prime N e a l e ~ r e p o r t s ~ o n ~ t w i l l ~ w e a v i n g ~}$ from Guatemala. ${ }^{112}$ The weavers of San Martin Sacatepequez equip the backstrap loom with a twin heddle "with heddle loops arranged in alternating spiral looping," a regular heddle and one pattern stick in order to have the four warp controls for a $1 / 3$ twill, and brocade weaves based on $1 / 3$ twill floats.

From Peru comes the colorful narrow wool tapes woven in a twill design with pick-up sticks which are reinserted in the warp after each weft. The tape has an all white warp 
and tie-dyed weft in five colors. Figure 75 shows the twill band and the weave draft. The reproduced design is seen in Figure 88. The tape used as bindings for ponchos and very easily woven with small pick-up sticks would require 10 heddle rods. This would seem very impractical when one considers the narrow width and the high number of heddle rods.

O'Neale also writes about a present day belt loom from the Andean village Pariahuanca in the highlands where three heddle rods and a "slender crotch shaped stick" give the four warp divisions for the twill weave. ${ }^{113}$ The stick serves here as a shed rod and a lease stick (Figure 19). This study encountered four twill fabrics. One is the doll dress \#TM 1961.002a in the Textile Museum, Washington, D.C. It is a $2 / 2$ diamond twill with 22 yarns in one repeat probably from the Chancay Valley, Late Intermediate Period. Figure 76 shows the doll, Figure 77 shows the weave draft and Figure 88 the reproduction. Although the heddle arrangement of the reproduction was planned at the warping board (Figure 77), the Peruvian weaver probably developed the design from the first weft at the bottom selvage. which at a closer examination began at the point of the diamond. This would mean, if the piece was woven on a multi-heddle loom, that the first four wefts were picked up with a pickup stick and a new heddle rod was laced after each pick-up. 

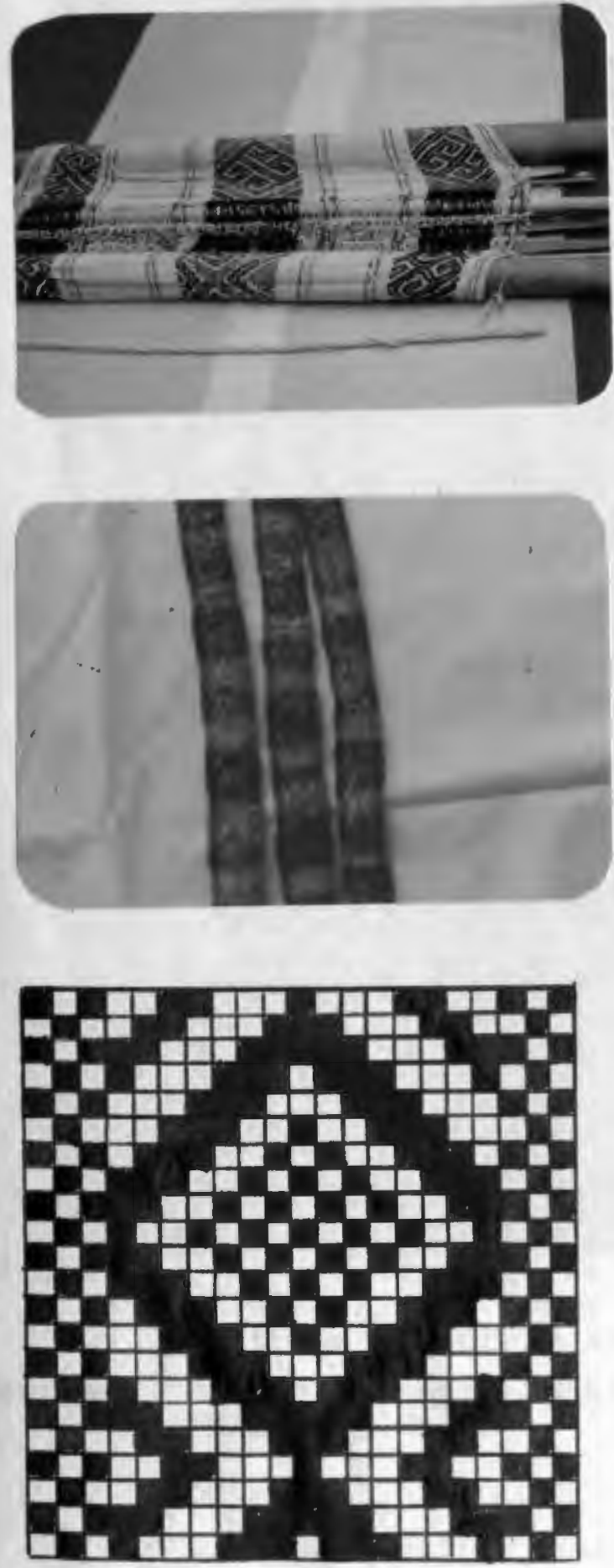

Figure 74. Twill woven by Cashinana Indians. Source: Haffenreffer Museum, Brown University.

Figure 75. Contemporary twill band. Woven in Cuzco area. Owned by author.

Figure 75. Weave draft of twill band.

Warp: 3 red, 15 white, 3 red yarns. Design is hand picked in a combination of $3 / 3$ twill and plain weave 


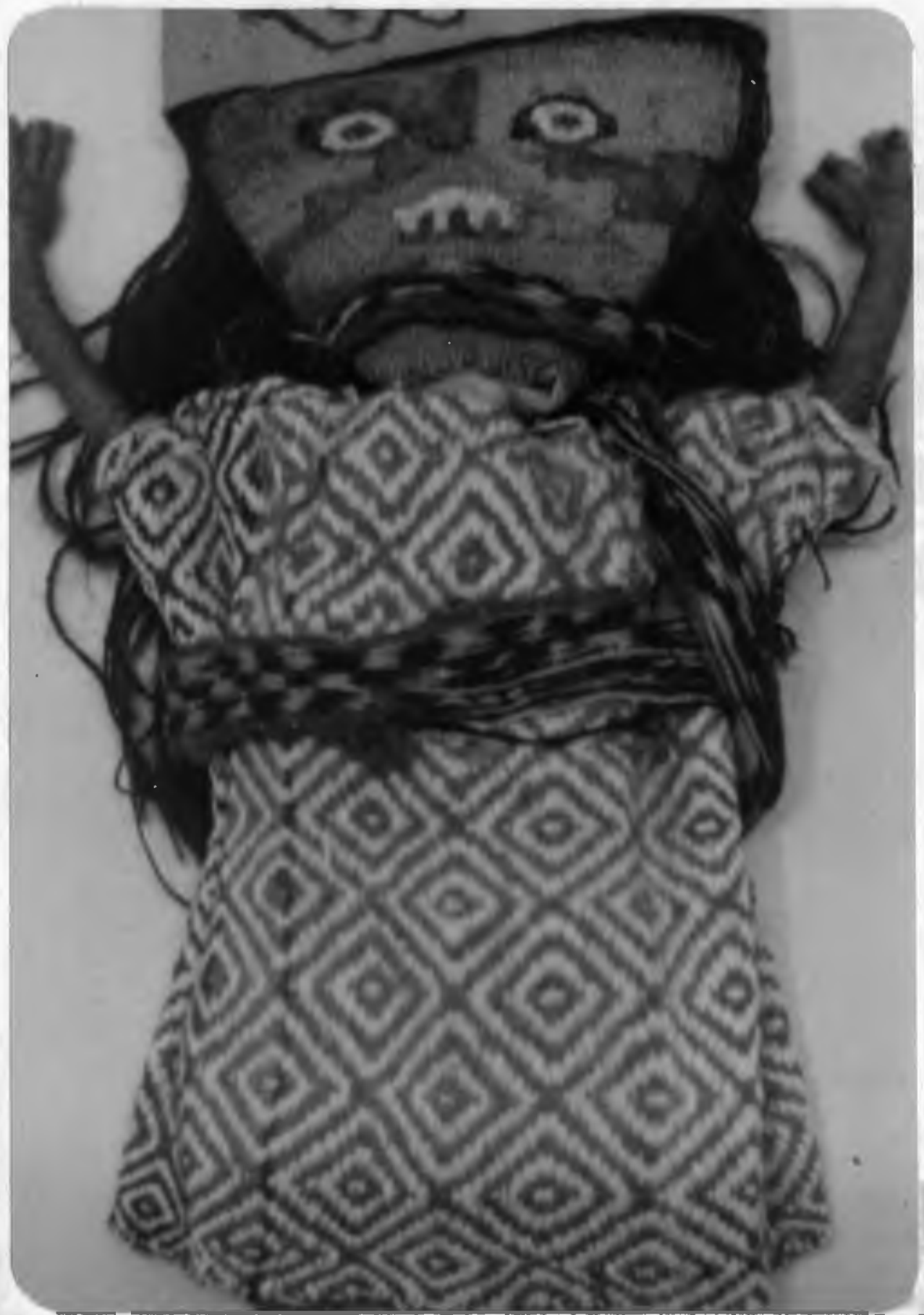

Nigure 76. Doll weaving tunic woven in $2 / 2$ diamond tirll (weft-faced) brown and white cotton with stripe of purple and white.

Source: Textiles Museum, Washington, D.C. \#TM 1961.002a. 


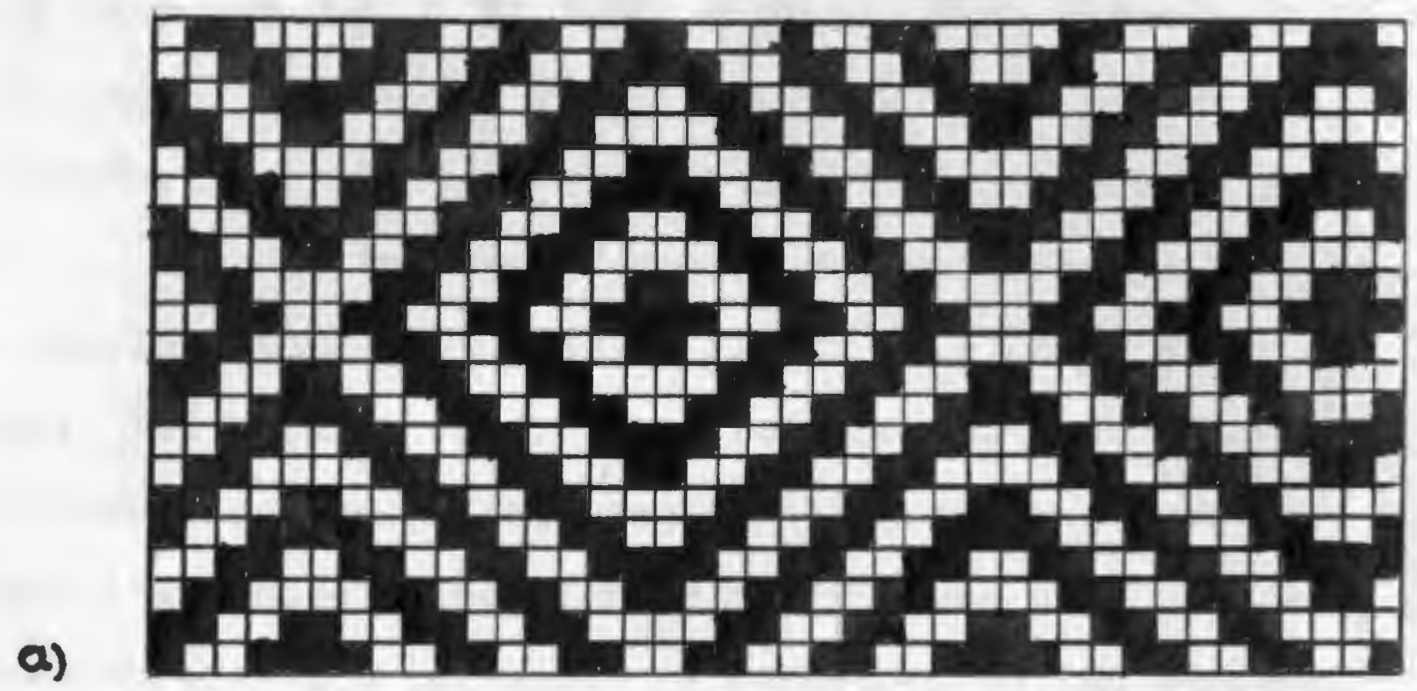

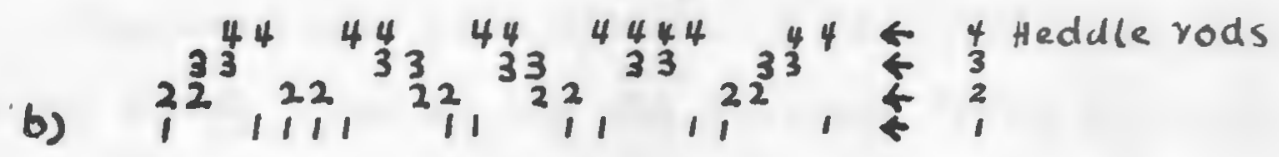
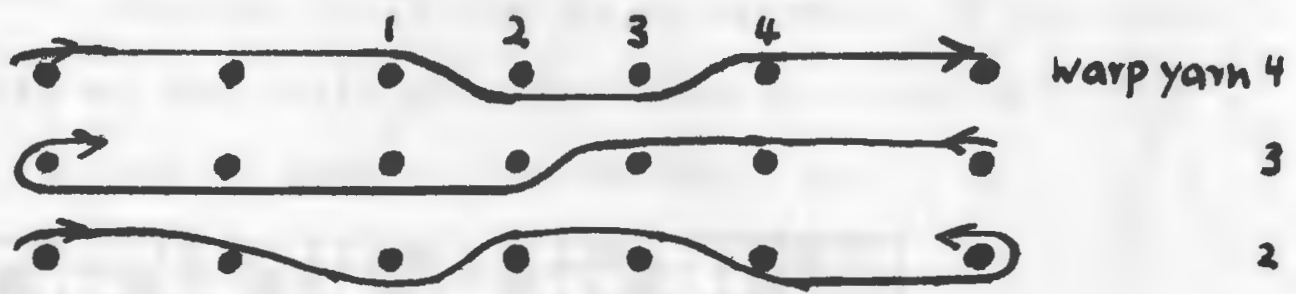

c) $\overrightarrow{0}, 0$

Figure 77. Weave draft (\#TM 1961.002a).

(a) Weave draft of $2 / 2$ diamond twill.

(b) Heddle arrangements for the four warp divison.

(c) Warp controls planned on warping board.

- warp

- pegs on warping board 
The second textile, \#244.296, is from the collection of the National Museum of Natural History, Washington, D.C. It is a mummy wrapping, a blanket from a grave in the Valley of Chicama, made of white cotton with blue stripes in groups of three. It has triangular corner designs woven with a blue supplementary weft in twill floats on a plain weave ground. The blanket consists of two panels, each 2 feet and 1 inch wide and 8 feet long, which are sewn together at the longer side. The diamond twill based on a $1 / 3$ twill started at the warp selvage. In reference to the shape of the design area, it is believed that the twill pattern was leveloped with pattern sticks.

Supplementary weft patterning is known from the Middle Horizon, Epoch 3 and 4, and the textiles feature brocaded corners. 114 Figures $78-79$ are an enlargement of the face and reverse of the twill pattern weave and the weave draft. The reproduction is seen in Figure $88^{\circ}$.

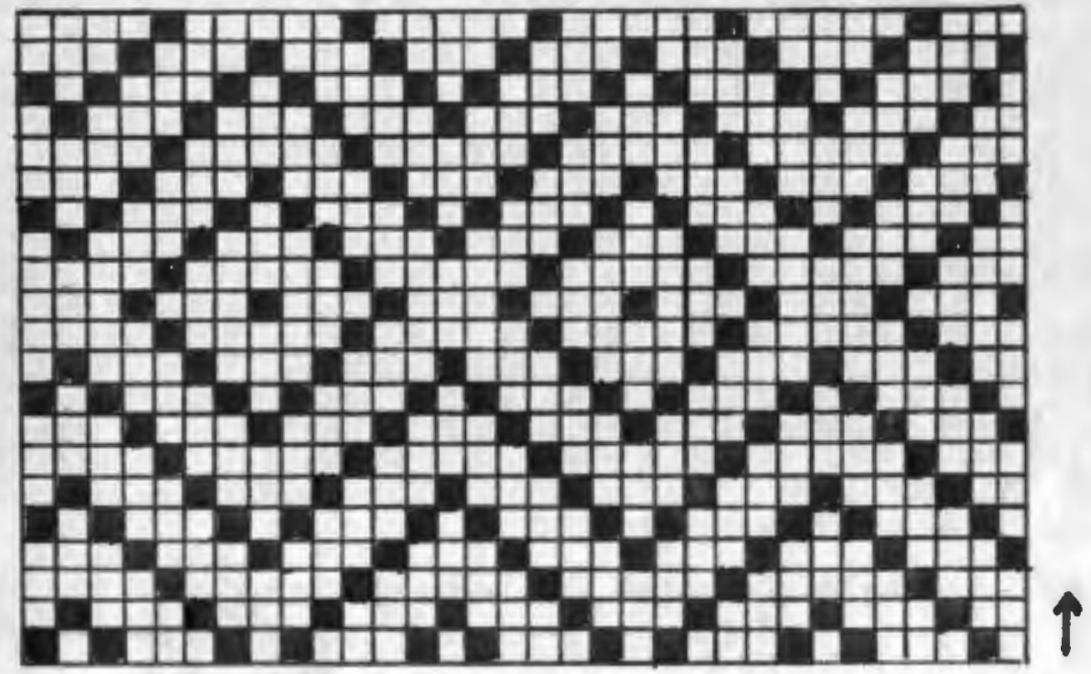

Figure 79. Weave draft. \#244.296. 


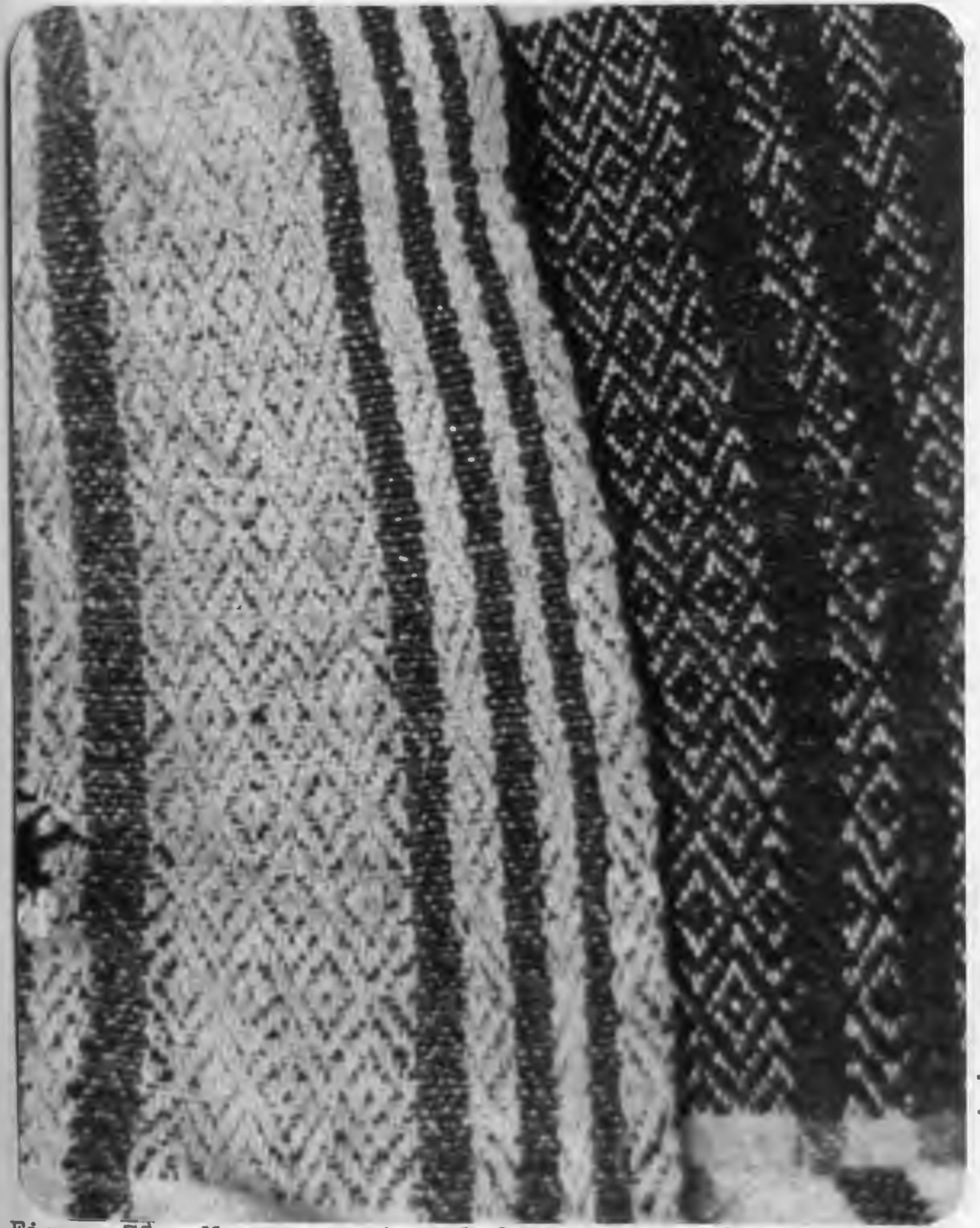

Figure 78. Mummy wrapping, left - reverse of fabric right - face of fabric

Source: National Museum of Natural History, Smithsonian Institute, Washington, D.C. \#244.296. 
The third textile is a vertical herringbone twill based on a broken $2 / 2$ twill with tan warp and dark brown weft in two-ply yarns with an approximate count of $24 \times 20$ per inch. Harner reports that this small fragment was found among 85 textiles from Ancon and the Chillon Valley, and dates from the Early Intermediate Period. ${ }^{15}$ The weave draft taken from the enlarged photograph would, if woven, require four warp divisions. Presumably the broken twill started by counting the first weft with occasional skips over four yarns or only over 1 yarn instead of the usual over 2 and under 2 sequence. Also, there appears to be a mistake in the left section when two warp yarns are woven together at the reversal of the vertical herringbone. Figures 80 and 81 feature the enlarged specimen and the weave draft.

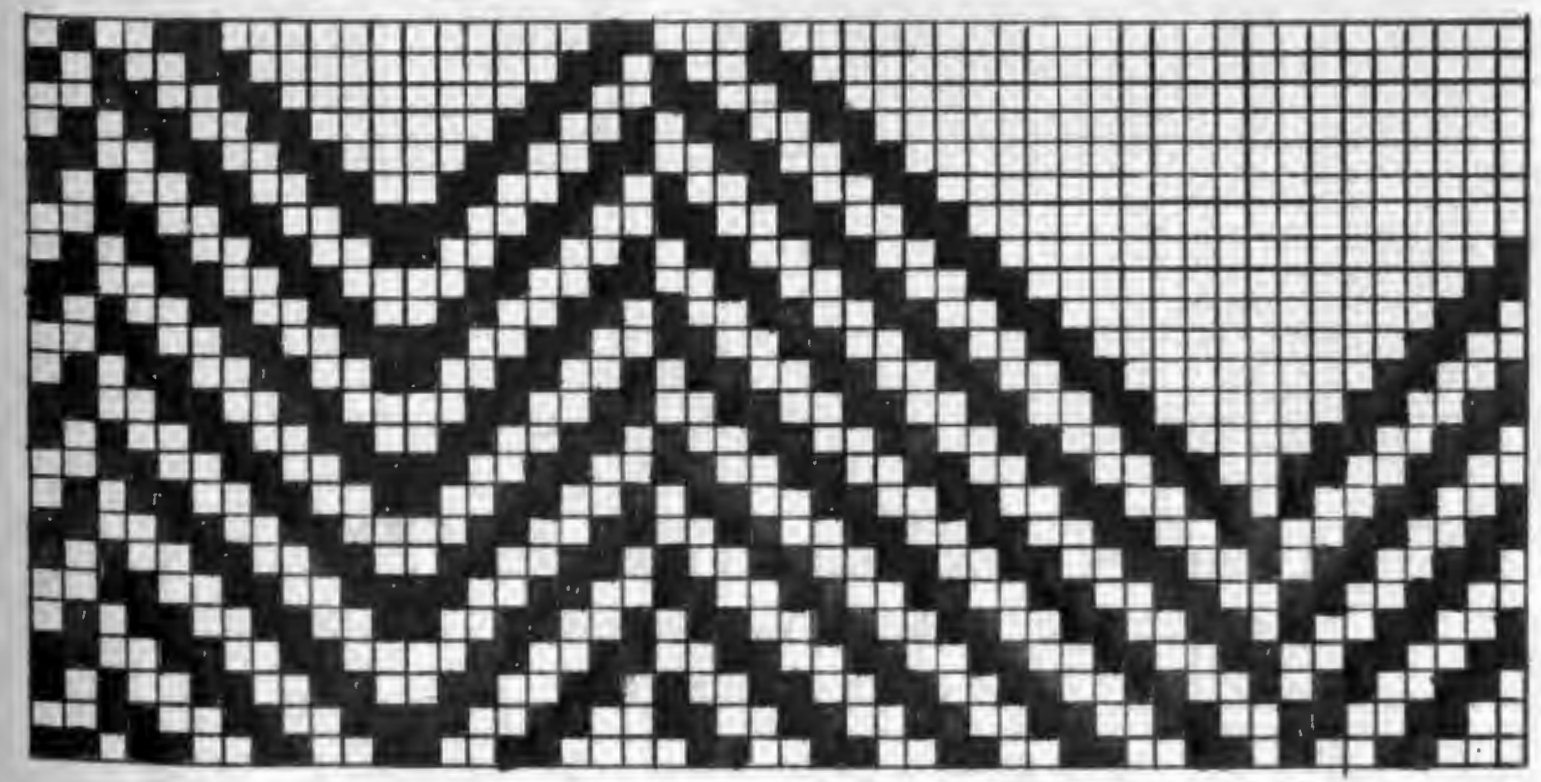

Mgure 81. Weave draft of broken 2/2 twill, Ancon. warp 


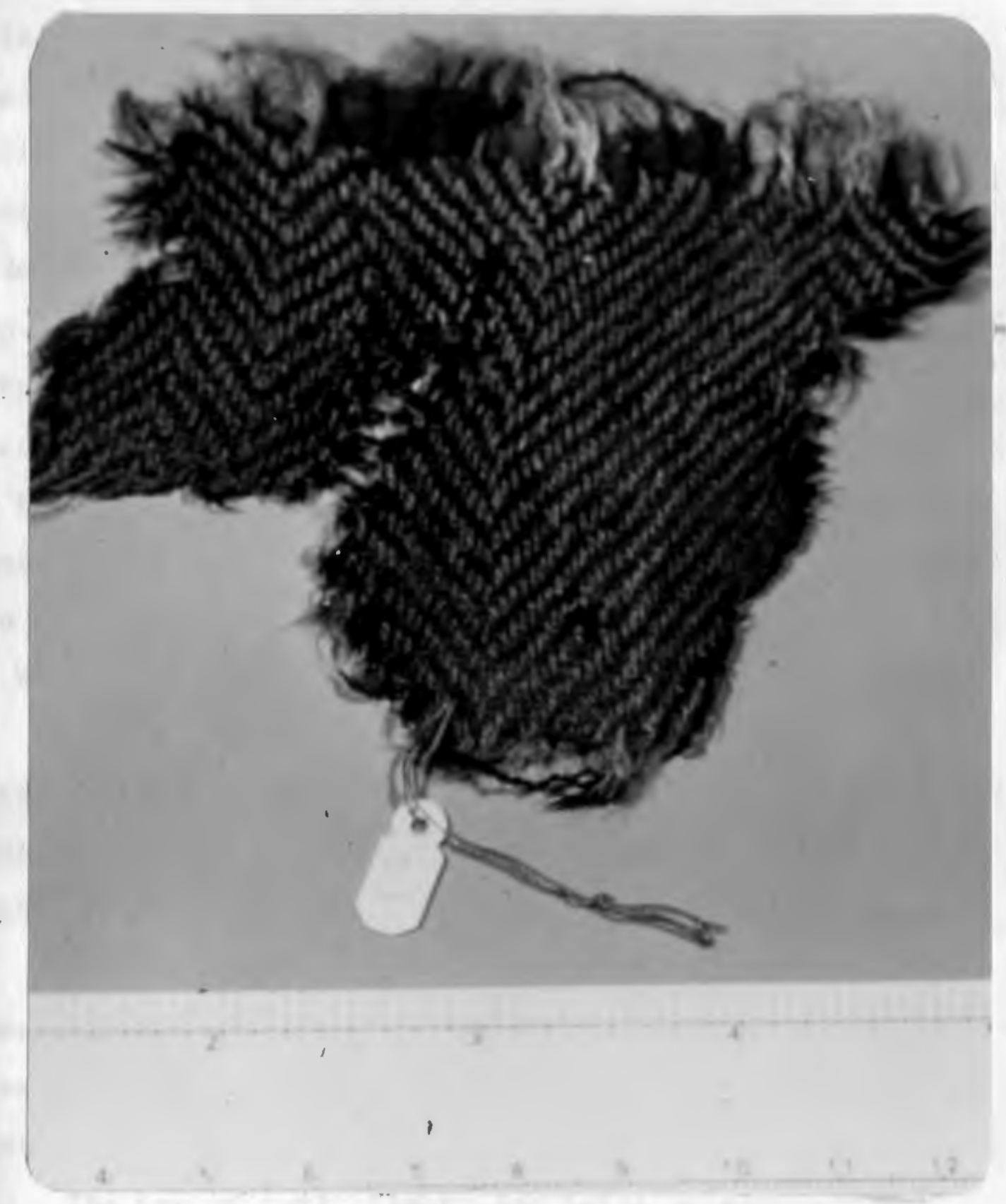

Figure 80. Broken 2/2 twill, Ancon. Early Intermediate Period. Source: Courtesy of Sandra Harner. 
The fourth twill fabric is a turned $1 / 3-3 / 1$ twill, unfinished and still on the loom. Number VA23841 is from Ancon, in the Sammlung Baessler, Museum fuer Voelkerkunde, Berlin. The loom bars are $49 \mathrm{~cm}$ long, the warp is about $30 \mathrm{~cm}$ wide and of brown two-plied cotton. The starting border is about $1 \frac{1}{2} \mathrm{~cm}$ high and in plain weave. Then the warp on the wefts are interruped for about $3 \frac{1}{2} \mathrm{~cm}$. The warp control is achieved with three heddle rods and one shed rod (which is destroyed and left in the warp). Two shed rods for the plain weave are also kept in the warp probably as lease sticks. On the backside is a tenter for maintaining even weaving width. No date is available for this specimen. Dr. Eisleb places it later than Middle Horizon. 116

Figures 82-85 bring close-up and overall view of the textile and a weave draft of one portion of the design. The heddle arrangement is probably developed from the figure eight which is established on the warping board.

This twill was presumably woven on a multi-heddle loom. The design is easily developed from the diagonal lines with a pattern stick plus the shed controlled by the heddle rod.

The use of twill floats and twill successions for patterning are frequently noticed. Van Stan describes an apron-like cloth from the Late Period (Pachacamac \#29568) which has a border wih a two-color twill pattern. ${ }^{117}$ 


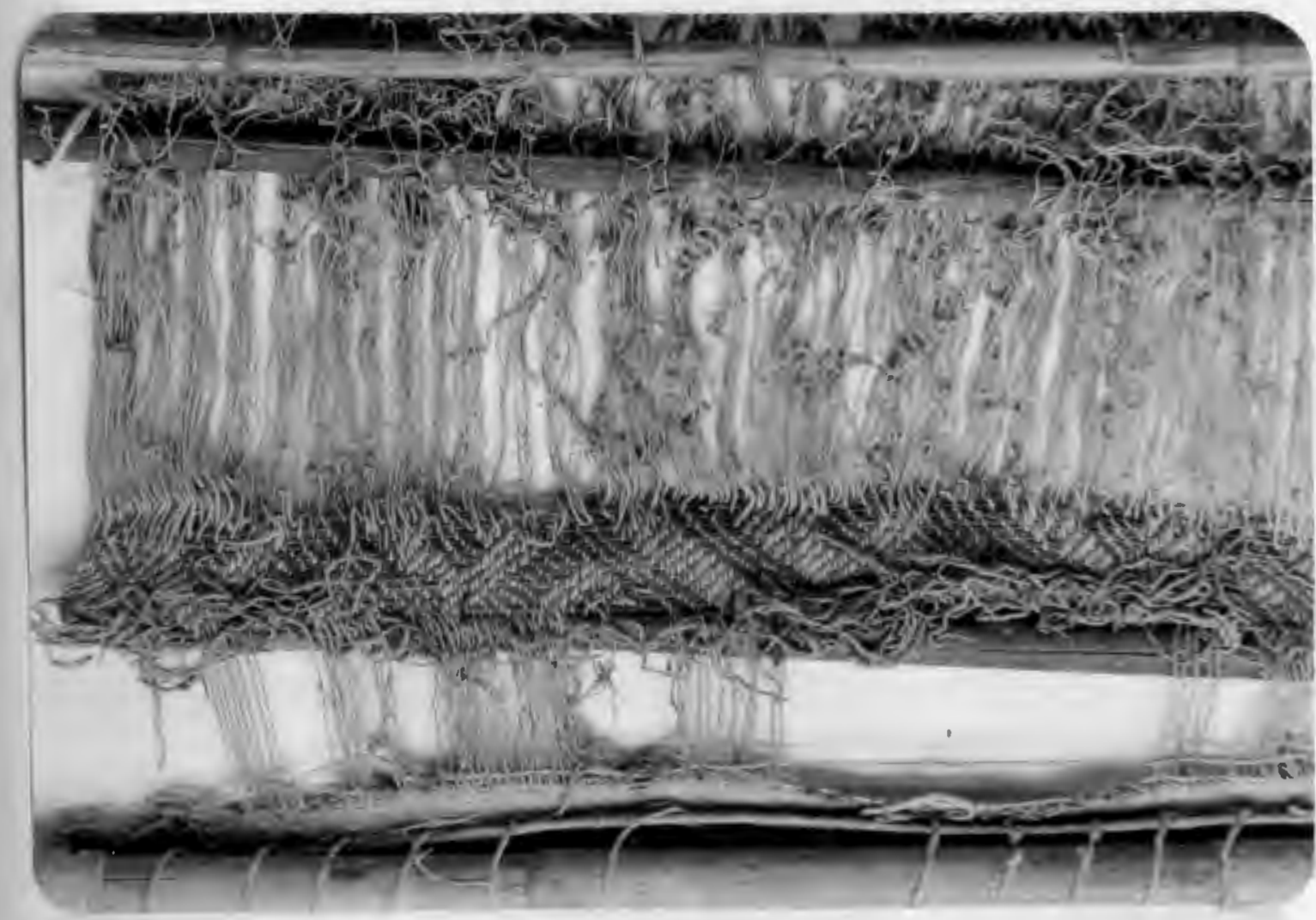

$\underline{F a c e}$

Tigures 82, 83. Face and Reverse - 1/3-3/1 turned twill.

Source: Museum fuer Voelkerkunde, Berlin. (Ancon, Sammlung Baessler) \#VA 23841. 


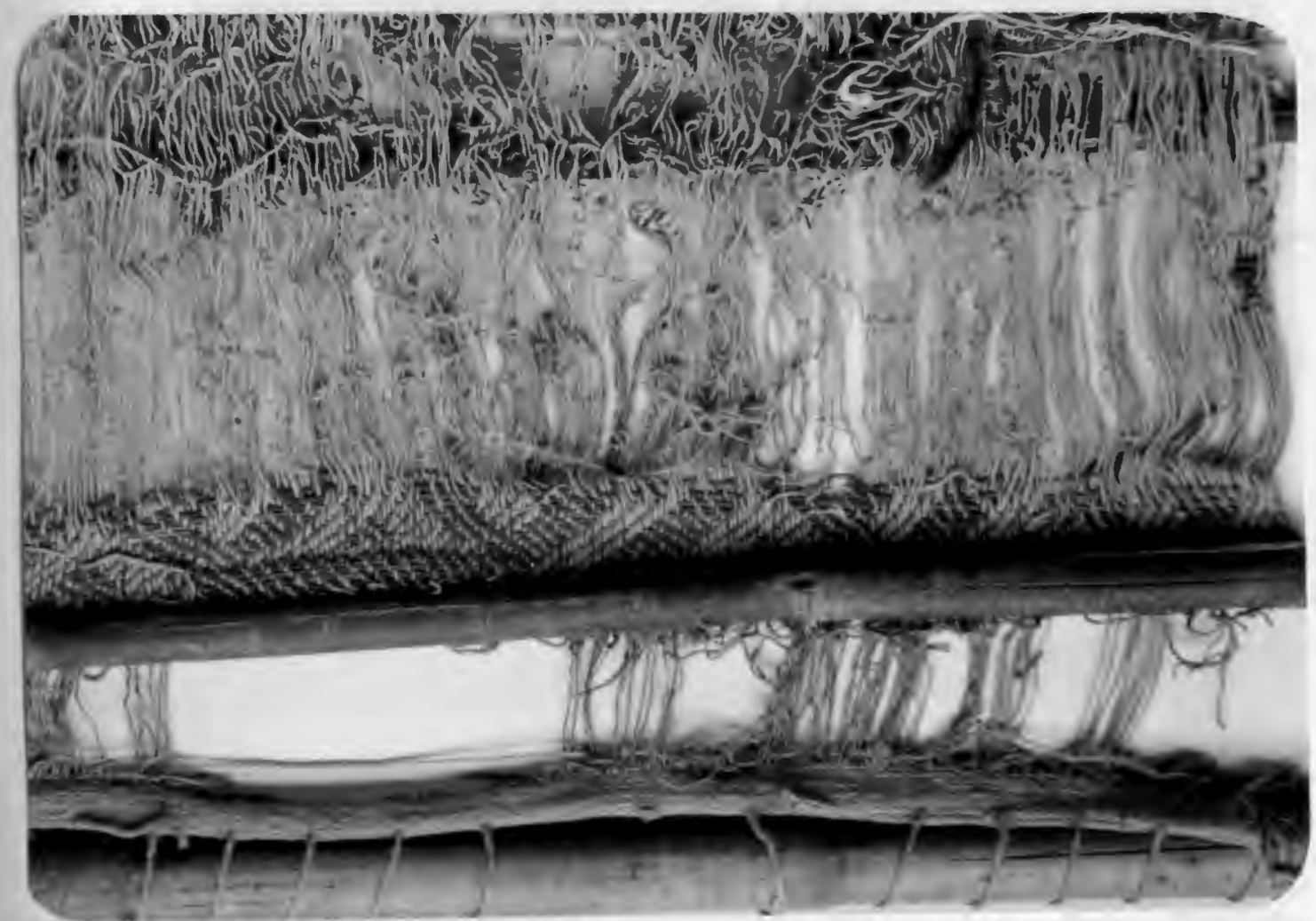

\section{Reverse}

Figures 82, 83--Continued 


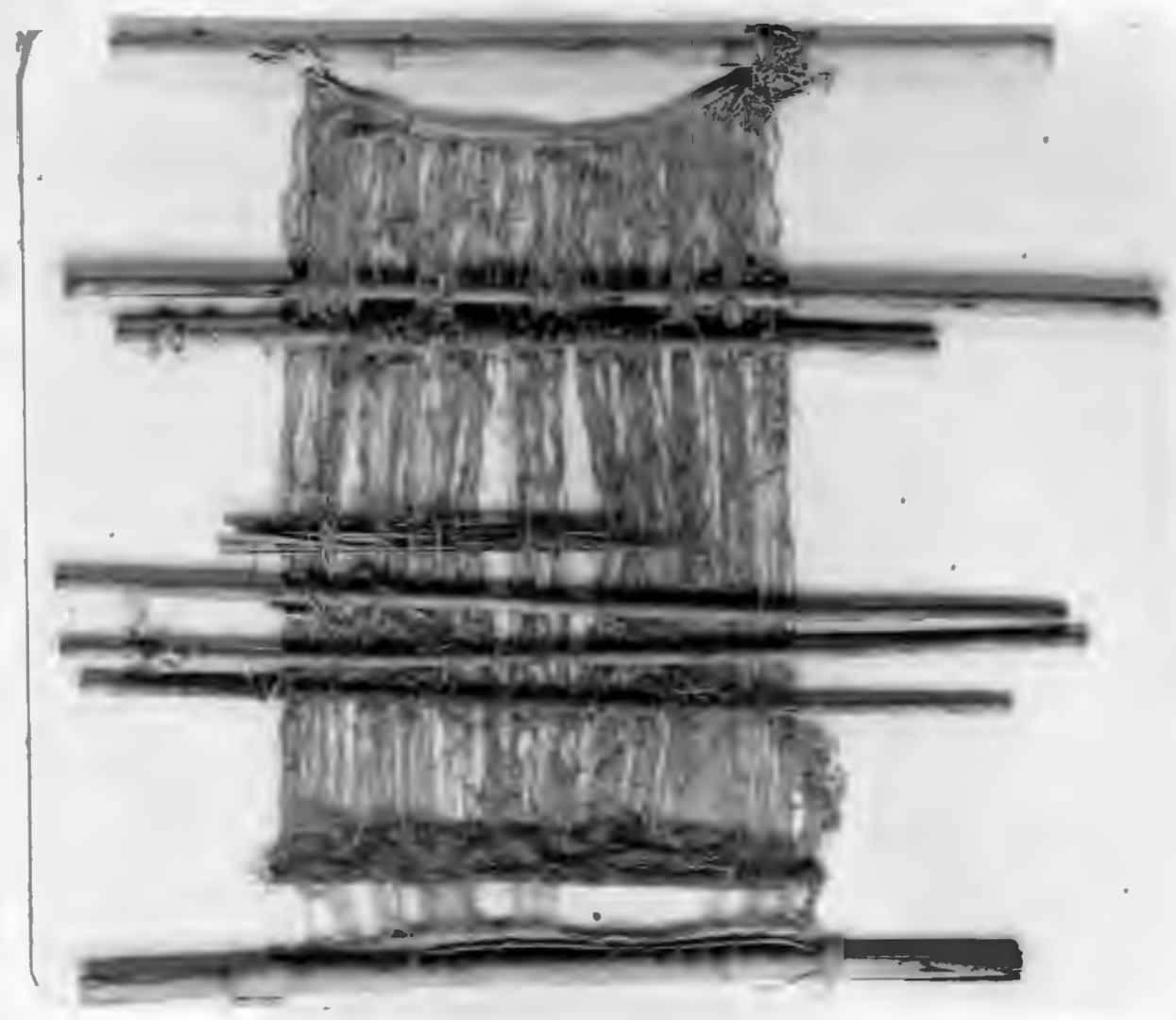

Figure 84. Overall view. \#VA 23841.

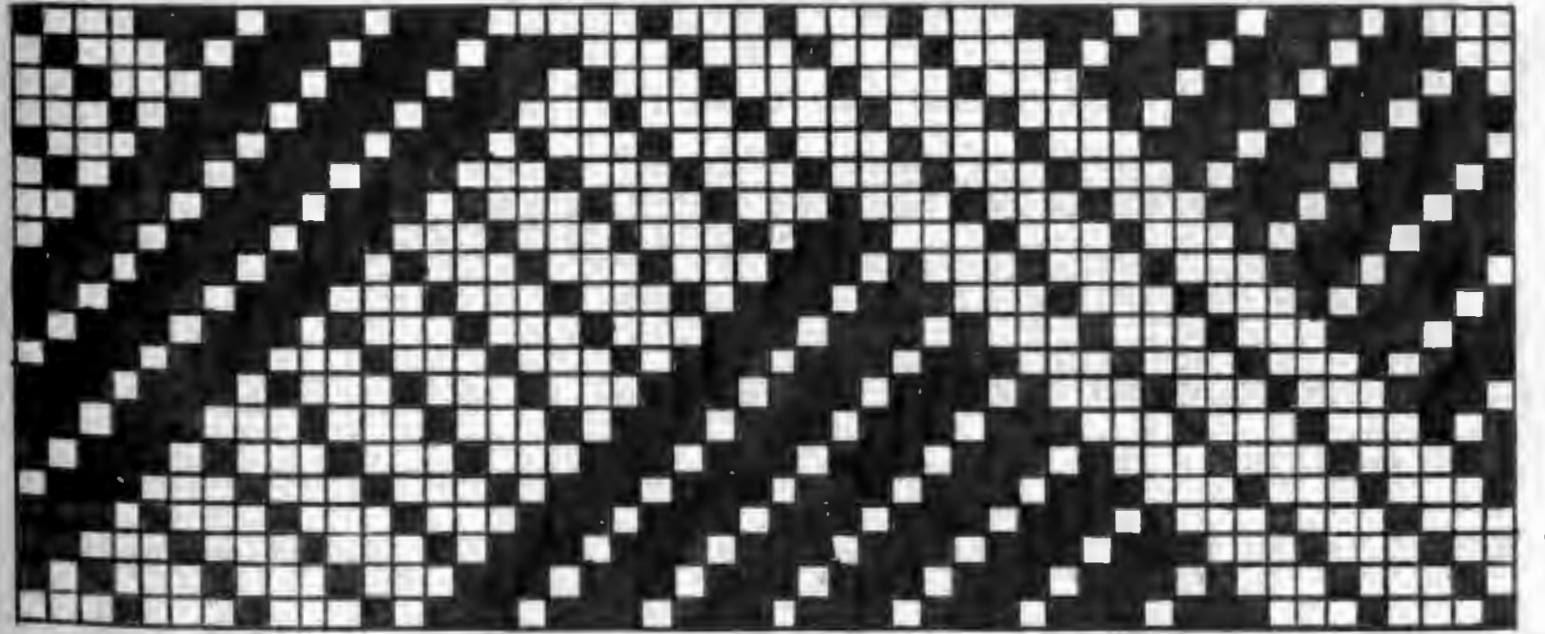

Figure 85. Weave draft. \#VA 23841. warp 
Two sets of alternate wefts, each set in one color, appear to be woven in two separate $2 / 2$ twills over triple yarns. Actually the weaving is done in a type of bound weave. Two wefts, one of each color, cover all the warp yarns. And the next two wefts move to the left for one triple yarn (Figure 86). The same polychromatic effect was noticed on

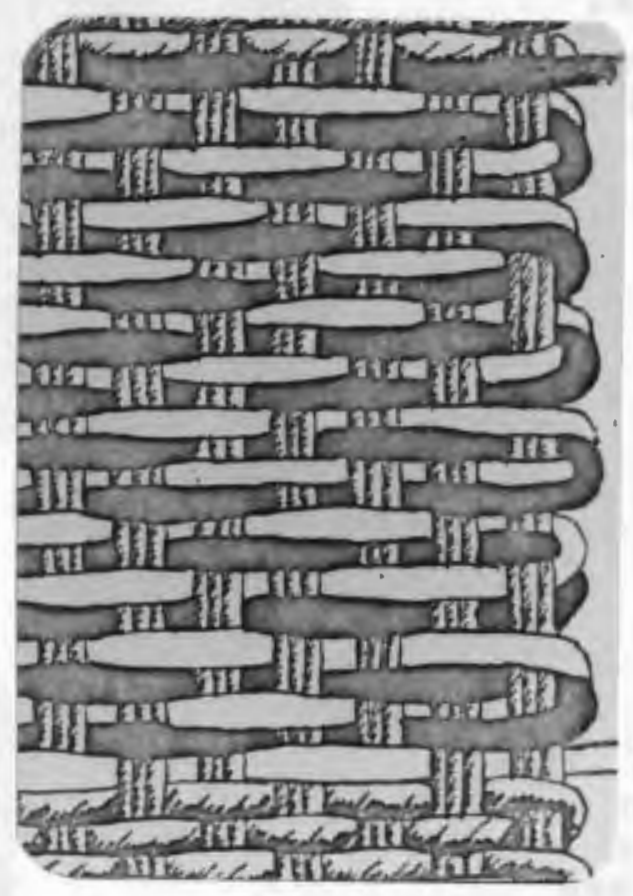

Figure 86. Reconstruction of a two-color twill (diagram). Source: Ina Van Stan. Textiles from beneath the Temples of Pachacamac, Peru (Philadelphia, Pa.: University of Pennsylvania), I967. \#29568.

a small sample loom in the Peabody Museum, Harvard University. The small border next to the exposed warp yarns is woven in a two-color twill. The white weft floats over and under three Jarns, and the dark-brown weft floats under and over the same yarns (Figure 87). 


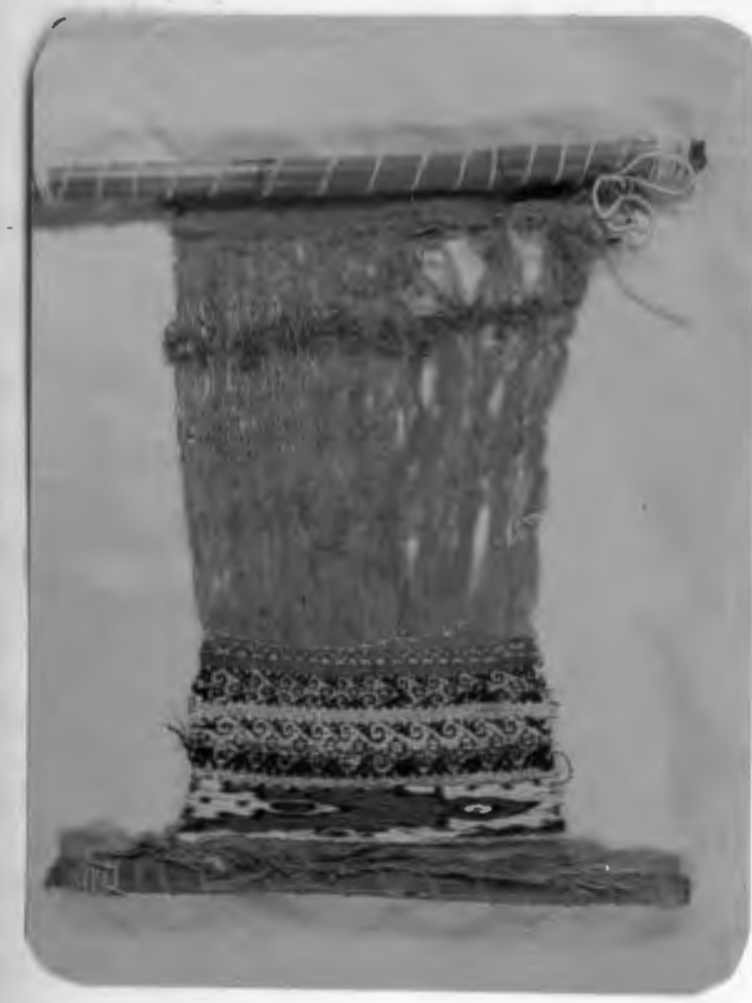

Figure 87. Small sample loom with band in twocolor twill.

Source: Peabody Museum, Harvard University.

Note: Probably from end of Middle Horizon or Late Intermediate Period. No number.

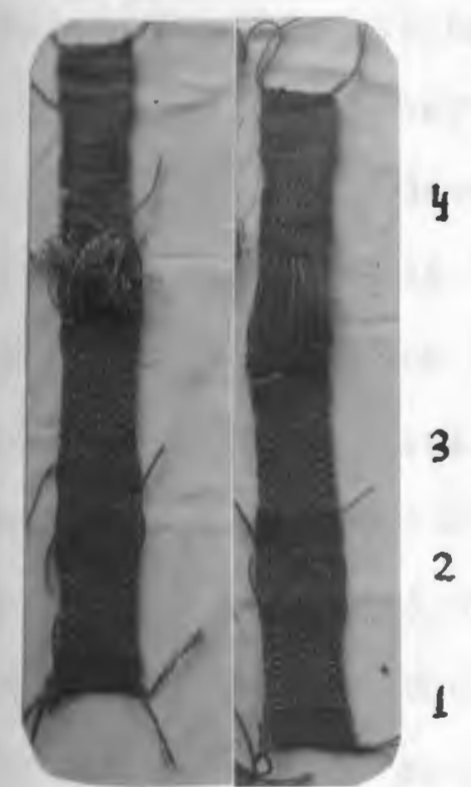

a

b

Figure 88. Reconstruction of twill weaves. Experimental weaving by author.

1. Supplementary weft pattern in diamond, woven with 3 heddle rods, I shed rod - without plain weave.

2. Present day twill tape (Cuzco) woven with pick-up sticks.

3. A $2 / 2$ diamond twill of tunic, woven with 3 heddles, 1 shed rod.

4. Patterned twill ( $1 / 3$ and $3 / 1$ ) woven with 3 heddle rods, 1 shed rod. 
In summary, of all the researched twill weaves, only one could be woven with a straight twill threading of the warp yarns in the heddle loops. The threading was developed from the figure eight of the warping procedure when the warp was under tension and lashed to the loom bars. It was the patterned twill (Figure 82). Here each raised heddle rod opens the shed for the $1 / 2$ twill floats and acts also as a guide for inserting the pick-up stick for the $3 / 1$ twill floats. One of the solutions suggested by O'Neale ("to raise one heddle and at the edge of the pattern motif raise the two other required heddles") is theoretically possible but not practical when one realizes that the heddle rods have to be lifted anually with one hand while the other hand handles the shuttle. 118 The above mentioned technique is fast because the design develops along the diagonal line.

All the other twills require a specific warp control which at best is developed with the wefts of the first repeat of the design. One has to understand drafting to plan the warp control, before hand, on the warping board. The frequency of broken twills and especially Harner's twill of the Barly Intermediate Period seems to point towards the use of pattern sticks and developing the design from key lines such as the points of the diamond. And this becomes even more convincing when one compares this with 0 'Neale's observation that: - Guatemalan weavers rig their loom with one supplementary heddle and then manipulate small sticks to depress one or the other half of the warps under the control of the regular heddle.119 
Satin

Continuing with the thoughts which were raised during the discussion on twill, it seems to be unnecessary to question why the satin weave is absent among Peruvian textiles.

Satin is a rearranged twill where "the diagonal lignment is intermittent," the floats are always bound single and "successive wefts are never bound by adjacent warps."120 The binding points are arranged in a set order and with a $1 / 6$ satin which can be in the counts of 2 and 5 , and 3 and 4 . The weave can also be woven on straight twill. The surface effects differ between these variations.

One experiment was carried out, initially, to observe the effect of the absence of the reed on a textile woven in $1 / 6$ satin weave. Two textiles with the same number of warp yarms and density were woven, one of the backstrap loom and the other on a 8-harness treadle loom with a reed. The fabric woven without the reed, when taken off the loom, had a spongy appearance and texture. The warp floats on the reverse side compacted horizontally even with a carefully controlled weft tension. Actually these floats formed ridges or welts which in themselves could be exploited in contemporary designs. Figure 89 shows the face and reverse side of the samples.

The experiment clarified what probably was a major limitation of the loom; namely, the difficulty of setting up the warp control for an irregular threading for a multiheddle system. In this experiment the solution was to plan 
the warp control in a straight twill, to count out the adjacent yarns for the next heddle rod and then to raise the heddle rods in the order of the binding points.

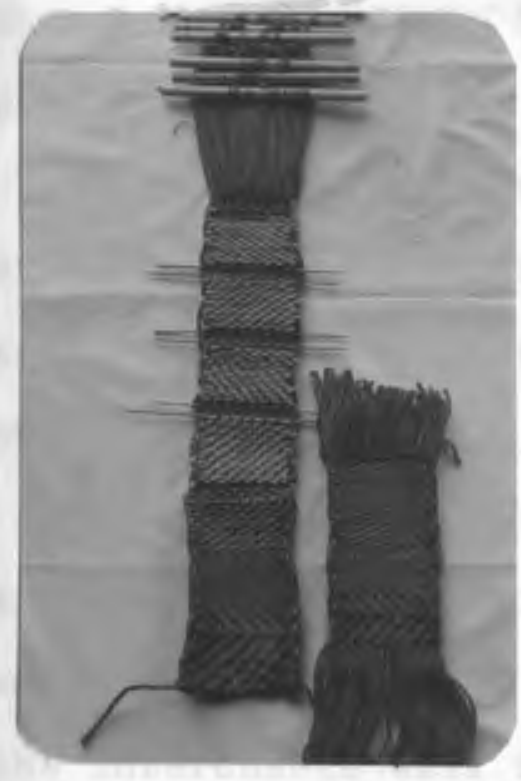

a $\mathrm{b}$

Face

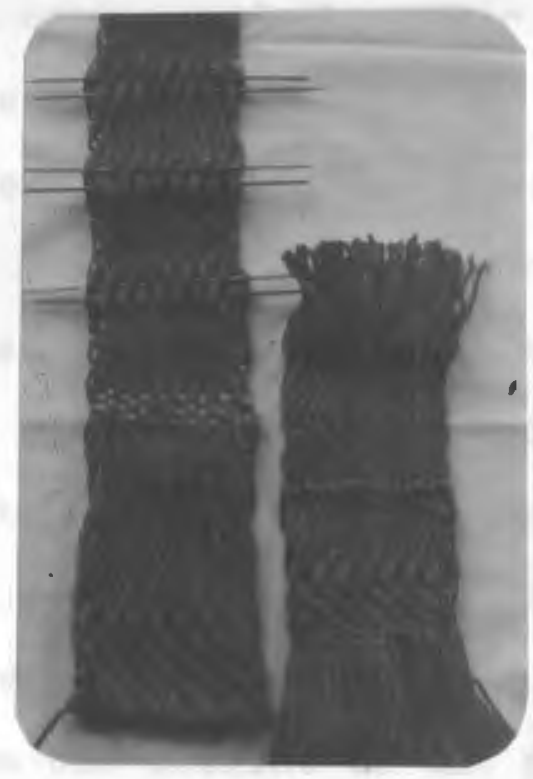

a

b

\section{$\underline{\text { Reverse }}$}

Pigure 89. Satin weave. Experimental weaving by author. (a) Seven-shaft satin woven on backstrap loom. (b) Seven-shaft satin woven on eight-harness loom.

\section{Wltiple cloth}

A multi-heddle system opens up the possibility of weaving two or more textiles simultaneously. Each textile is considered a separate unit. The weaving of a multiple of a textile would then require the multiple of the number of heddle rods which are required for the single textile plus provisions to keep the various layers separated from the one 
which is woven at the time. Since the backstrap loom functions with a rising shed, this means that only the top fabric can be woven by lifting single heddle rods. The warp yarns which are not raised would automatically belong to the weaving shed; therefore, the weaving of the lower layers would be required to keep the top layers raised.

In addition, the numbers of shuttles used and the direction of their insertion determines if the single textiles are woven as singles, are connected on one side to produce a wider width, or on two sides to form a tube.

Aside from this structural application there is the pattern application by which two or more single textiles cxchange areas. The weft moves from one layer to the other and the interchange will form the outline of the design. In the double cloth the interchange generally involves two plain weave fabrics with equal warp and weft counts, or high warp count.

\section{suvian double cloth}

The Peruvian double and multiple cloths generally belong to the pattern applications and less to the structural one alone. Usually the latter, in the form of narrow tubes, belts or cords, or small size bags, is in combination with the pattern application. The assumption that the Peruvians exploited the structural application for weaving wide fabrics, up to seven layers, is not proven and highly unlikely. 
the other two are incomplete. Van Stan writes that "all the double cloth looms she has seen in Peru, had two or more sets of heddle rods and sometimes a number of small shed or pattern sticks." 126

The Museum of International Folk Art has one Huichol double cloth loom, \#FA 72.31-4, with a textile depicting a bird motif. It has three heddle rods and a batten which substitutes for the shed rod.

- two of the heddle rods (laced with string heddles) control the brown warps, one heddle rod and the batten control the tan warps. 127

Also the Cora Indians, Mexico, weave with three heddle rods and one shed rod, and presumably one pick-up stick (Figure 90). The number of accessories is correct in Figure 90, but the location of shed rod and the accessories does seem to be incorrect. The design shows Spaniish influence. It appears that the two different colored warp yarns were warped pogether to form the continuous warp and then lashed to the loom bars over one weft.

One of the background warps is led over the shed rod, the other and the two design warps are each controlled by a heddle rod (Figure 91). The instructions for weaving would be as follows:

1. Raise the design warps (heddle 1 and 2 together), pick up the design warps in pairs on a pick-up stick. a. Raise one of the background warps (heddle 3) and weave the background color in the shed underneath the pick-up stick. 


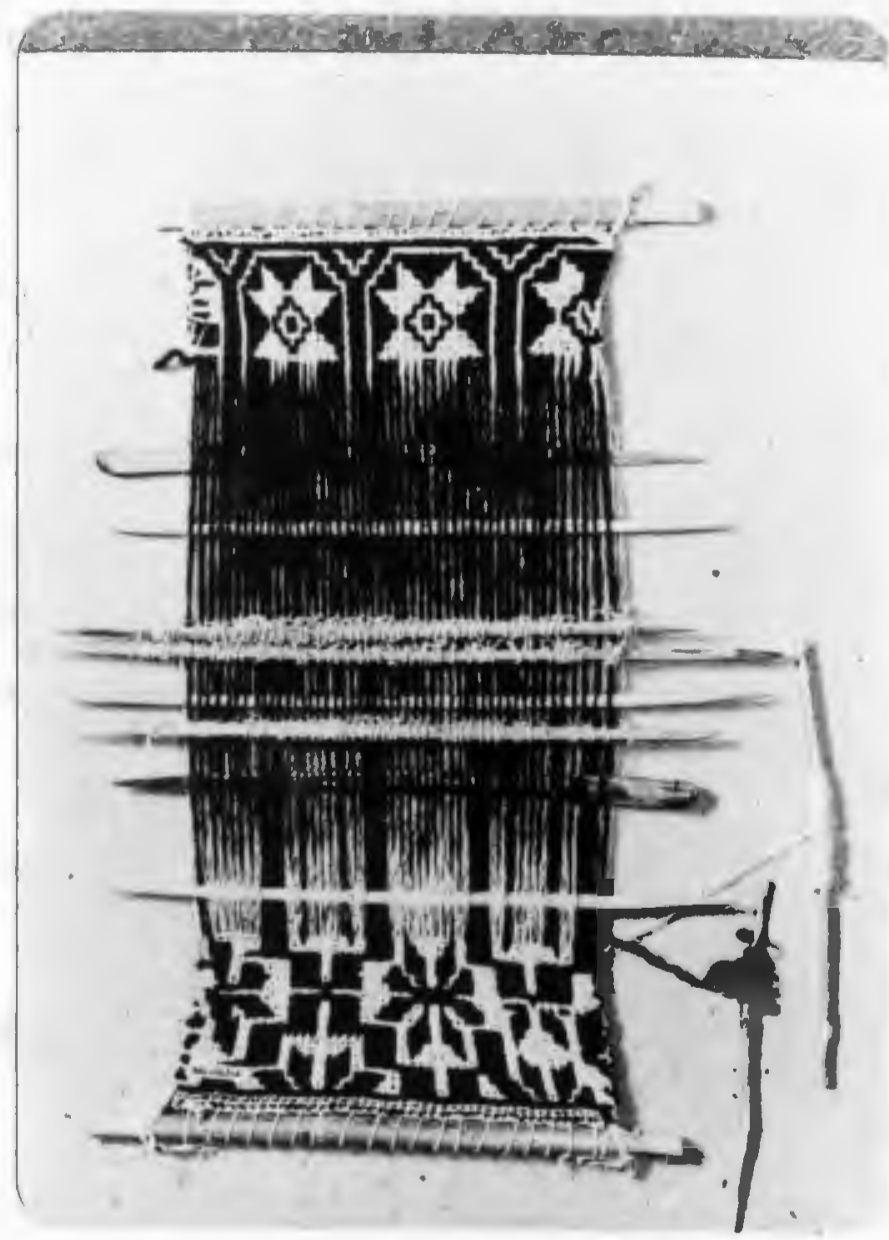

Figure 90. Double cloth loom (Cora Indian, Mexico, 1960). Source: Royal Ontario Museum, Toronto, Canada. \#961.26.5 
b. Push the shed rod forward and weave the second weft in the background color.

2. Push the shed rod forward and raise the other background warp (heddle 3), pick up the background design on the pick-up stick. Split the adjacent warp pair next to the design for a smooth outline or omit two yarns from the left or right side for the jagged outline.

a. Raise the first of the design warps (heddle 1) and weave the first weft in the design color.

b. Raise the other design warps (heddle 2) and weaye the second weft in the design color. Repeat 1 and 2 for each design unit.

And to weave areas without weft exchange with the background color in the top layer:

1. a. Raise the first of the background warps (heddle 3), weave the first weft in the same color. b. Push the shed rod forward and weave the second weft.

2. Raise both background warps (raise heddle 3 and push shed rod forward, then hold these warps with the pickup stick).

a. Raise first warps of the design warp (heddle 1) and weave.

b. Raise the other design warps (heddle 2) and weave the second weft. Repeat 1 and 2 for each design line. 
With the same procedure, but with interchanged yarns, the design color will weave as top layer and the background color as the lower layer.

In analysis patterned-plain-weave double cloth requires four single warp divisions for weaving and two paired warp divisions for the pick up. Non-patterned plain-weave double cloth requires four single yarn warp divisions plus one paired yarn warp division for weaving the lower fabric layer. Any loom set up, no matter if it is done with pick-up sticks or pattern sticks alone, or in conjunction with a plain weave warp control, or with heddle rods and one or two sheds, has to provide for the above listed warp controls.

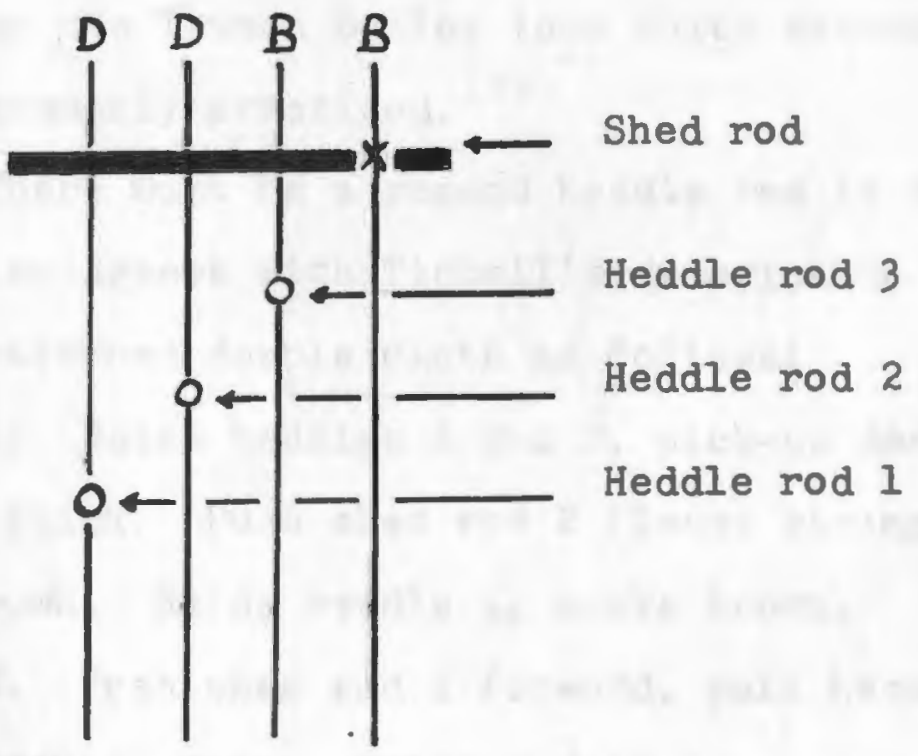

$\begin{array}{llll}1 & 2 & 3 & 4\end{array}$

Design warps Background warps

Figure 91. Warp control for double cloth. 
Tidball describes briefly the modern replica of the primitive loom in her collection (Figure 92):

- . note large shed sticks, one lifting all dark and alternate lights, the other the reverse. Heddle sticks, one to pull down, three $\ddagger_{28}$ pull up, form pick-up and weaving

The Truman Bailey loom, \#40.0/4023, American Museum of Natural History, New York, is also a reproduction of the Peruvian double cloth loom. Commissioned by Dr. Bird and with the threading, heddle rod arrangement and the weaving prepared and executed by Bailey's employed weaver Sinobia in 1949, it has warp controls (Figure 93) which probably are the same as in Figure 94 where a woman is seen weaving double cloth. Of additional interest are the double hitch lacing on the Truman Bailey loom which according to Dr. Bird is not commonly practiced. 129

There must be a second heddle rod in lease. string one which also agrees with Tidball's description in order to weave patterned double cloth as follows:

1. Raise heddles 1 and 2, pick-up design warps on pick-up stick. Push shed rod 2 (lease string 1) forward, weave brown. Raise heddle 4, weave brown.

2. Push shed rod 1 forward, pull heddle 3 down, pick up background warps. Raise heddle 1, weave yellow. Raise heddle 2, weave yellow.

To weave plain weave with brown on top:

1. Push shed rod 2 (lease string 1) forward, weave brown. Raise heddle 4, weave brown. 


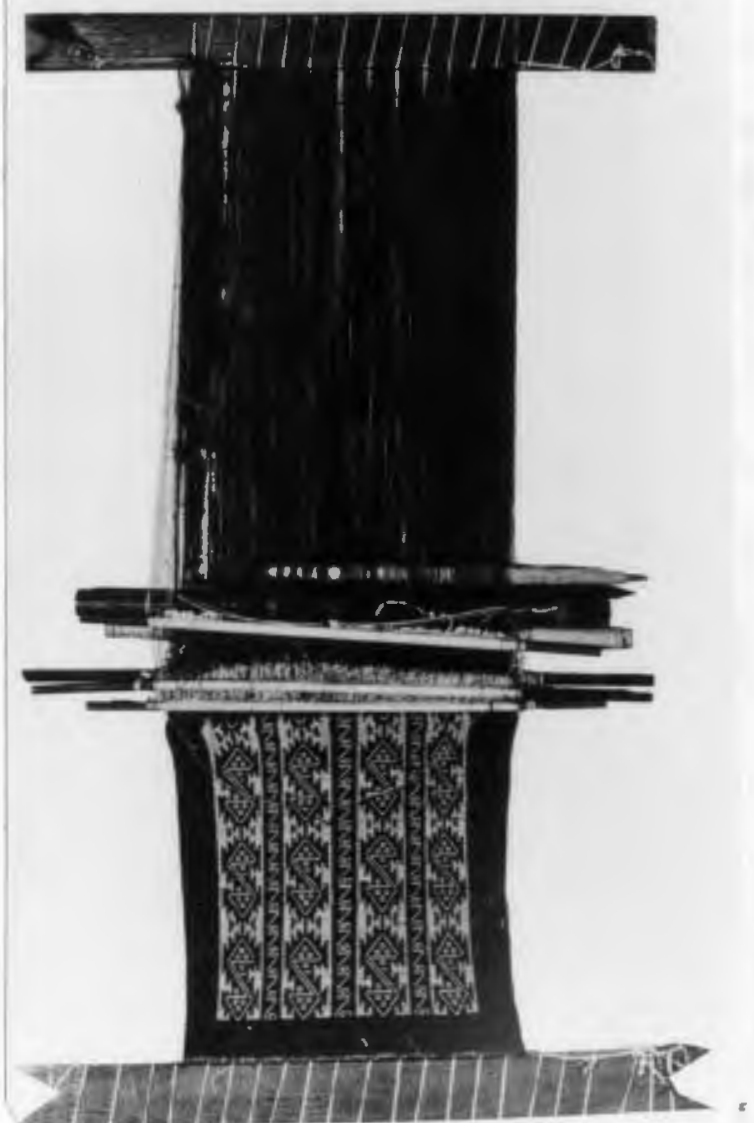

Tigure 92. Replica of Peruvian double-cloth loom. Source: Harriet Tidball. Peru: Textiles Unlimited, Part I, p. 5 . 
2. Push shed rod 1 forward, weave yellow. Pull heddle 3 down, weave yellow.

Since no other information could be obtained about contemporary double cloth weaving in Peru, it is likely that the Bailey and Tidball looms come from the same source, and are only reproductions that are not now used by Indian weavers.

warp width - 12"

warp length - 36"

yarn: hard twist wool loom bars - 29" long (notched) 2" wide
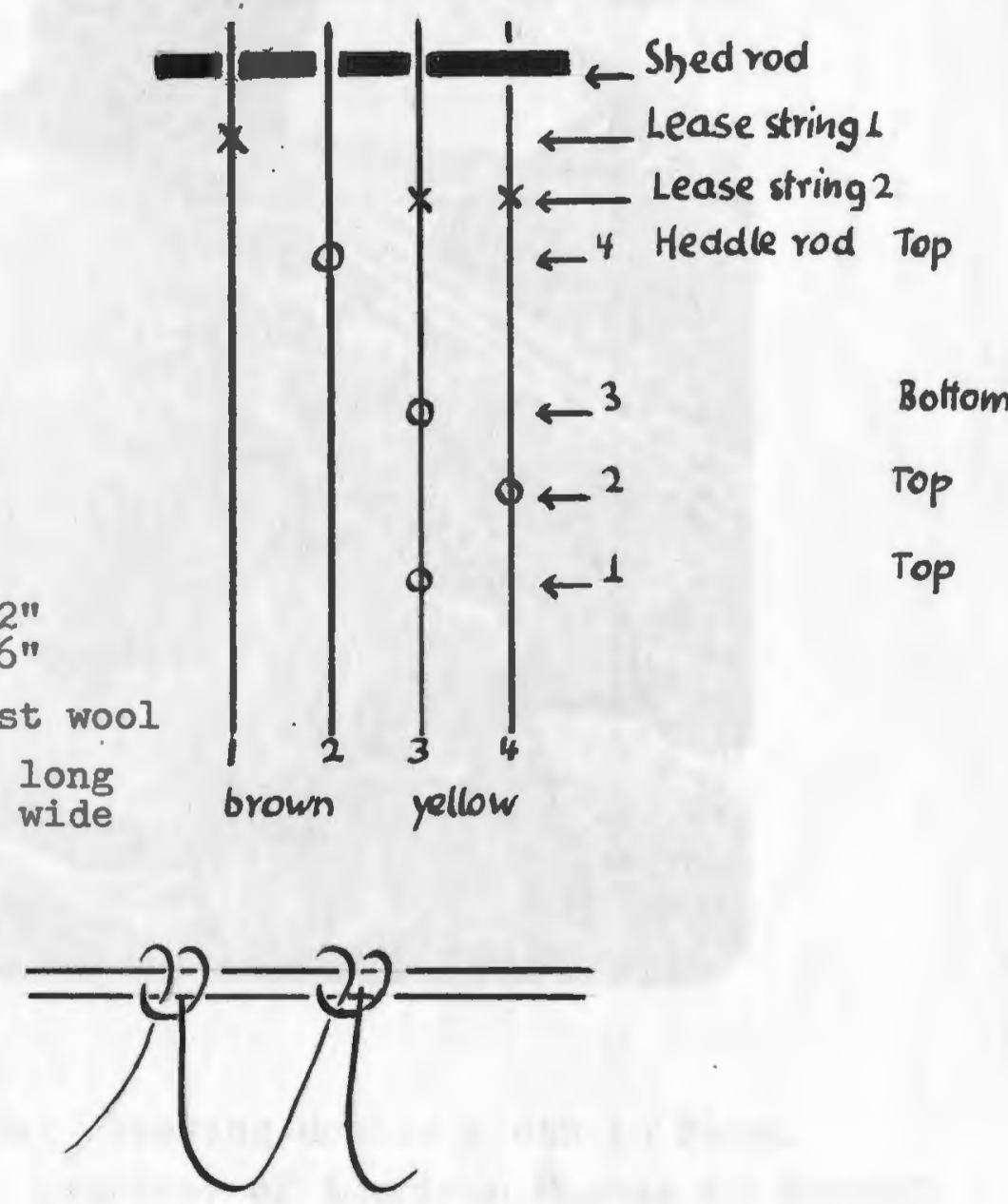

heddle lacing $40.1 / 4023$

Figure 93. Warp control for Bailey loom. 


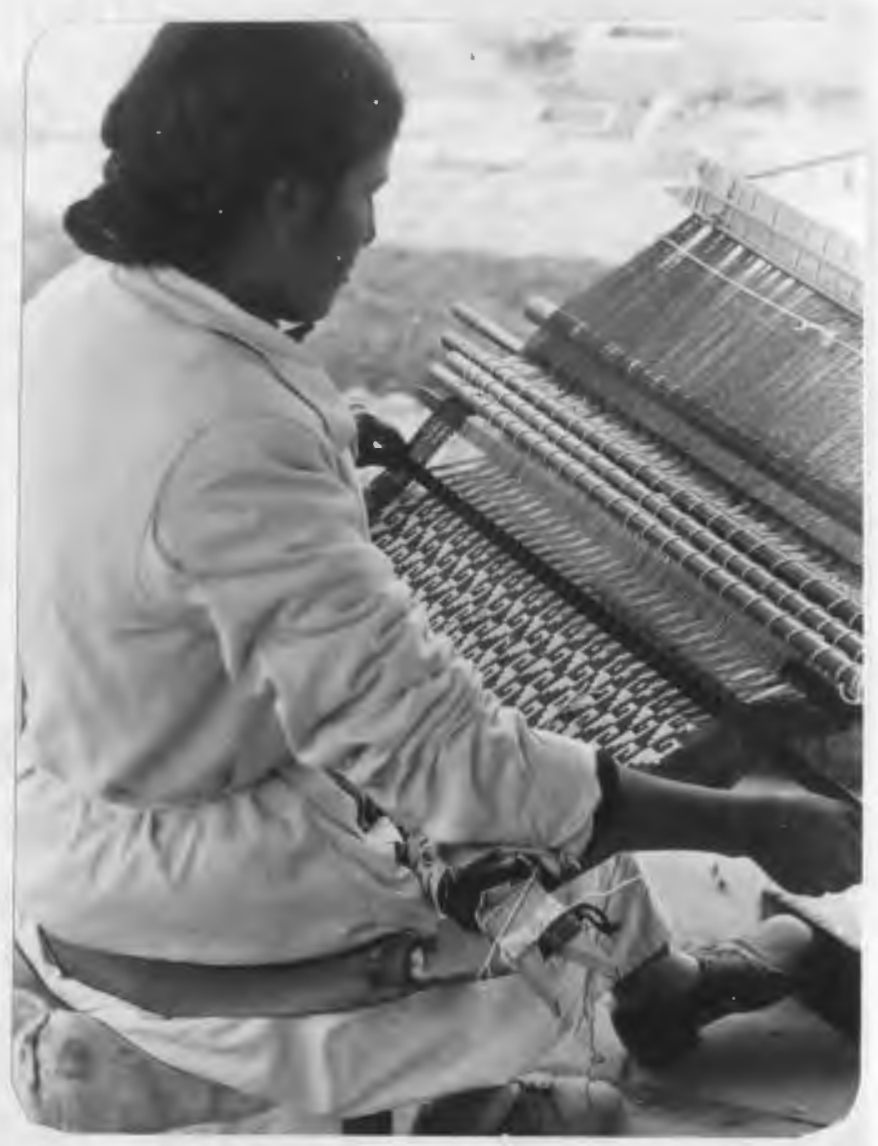

Figure 94. Weaving double cloth in Peru. Source: Courtesy of American Museum of Natural History, New York. Neg. 2 A 357. 
Three archaeological double cloth looms could be located. One is in the Amano Museum, Lima (Figure 95). It seems to have three heddle rods. The bar on top of the warp is a loom bar and definitely a wrong addition.

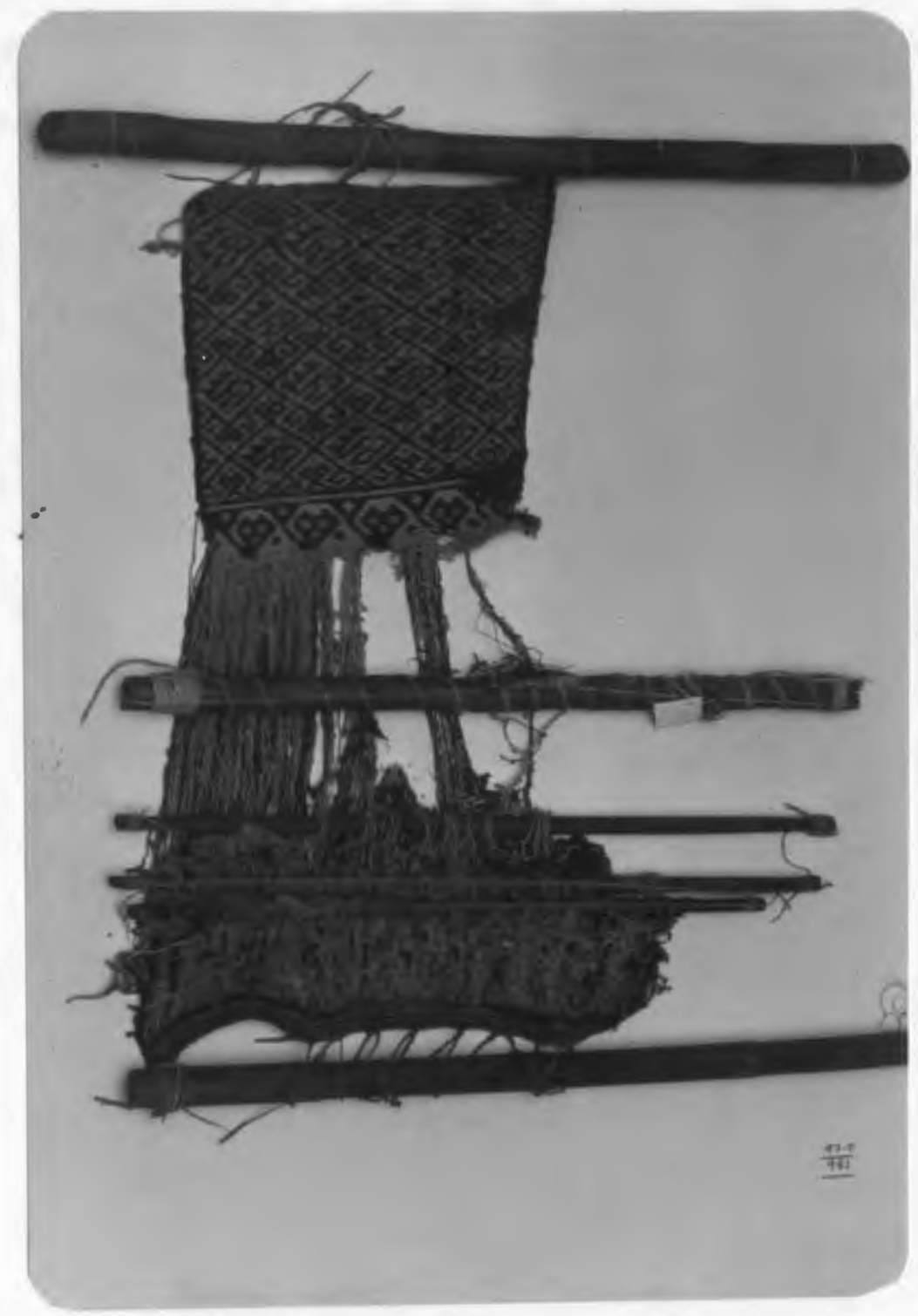

Figure 95. Double cloth Ioom, Amano Museum, Lima. Source: Courtesy of Suzanne Baizerman, St. Paul Arts and Science Center. 
The second is a very small loom in the Junior Museum of the Metropolitan Art Museum, New York, \#63.97 178013 tf, which is dated pre-Inca and has an unfinished double cloth of brown and tan wool. The warp is $14 \frac{1}{2}$ inches long, only 5 $3 / 8$ inches wide and is fastened to a $9 \frac{1}{2}$ inch long loom bar. The warp control is lost and "the warp threads are bunched in groups at unfinished end." 130 (Figure 96)

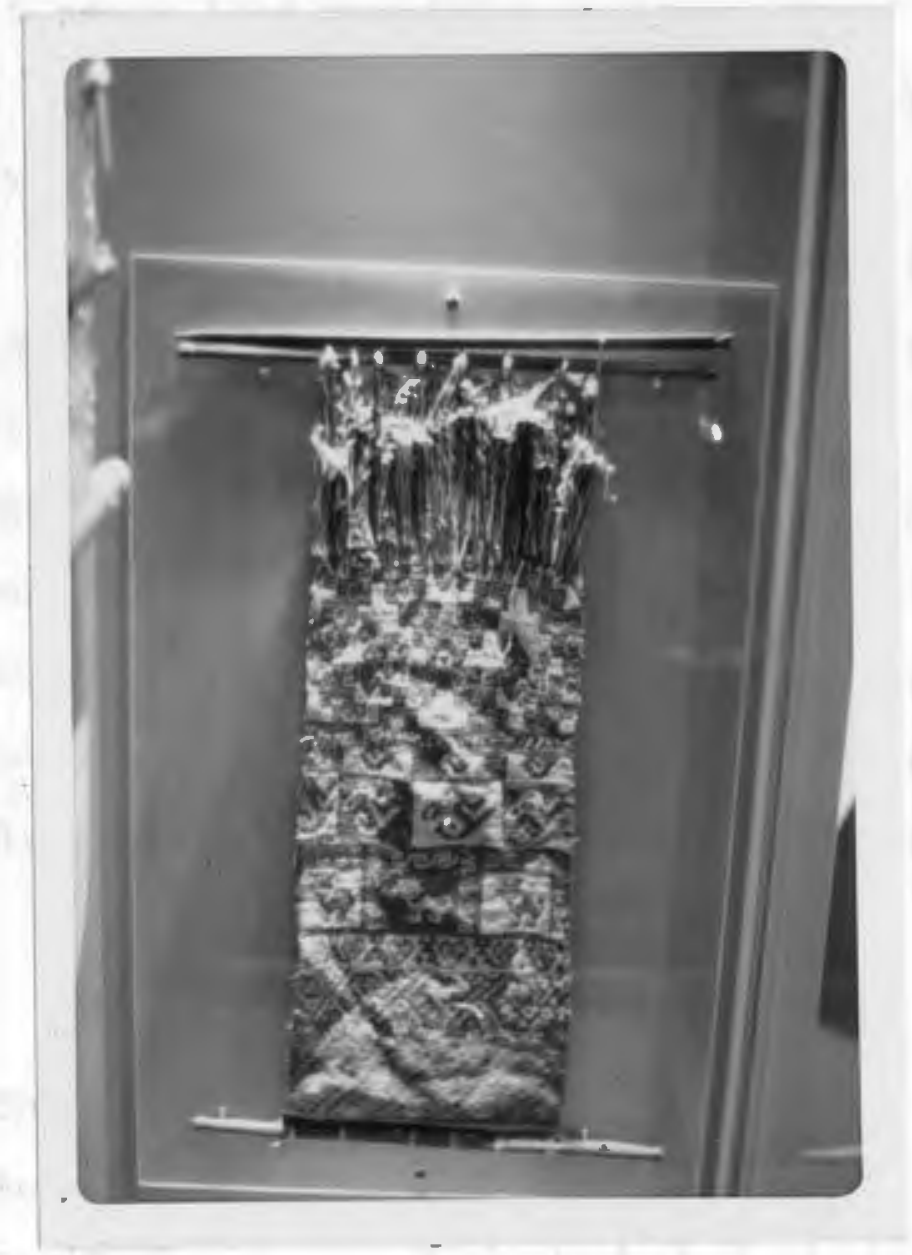

Tigure 96. Double cloth loom.

Source: Metropolitan Museum of Art, Junior Museum. Permanent exhibition. \#63.97 178013 tf. 
The third double cloth loom is \#B-7771 on display in the permanent exhibition of the American Museum of Natural History, New York (Figure 97). The loom was restored in 1962 and Bird gives the following information:

- . when restoration began only the loom bars were attached; the heddle, shed and other rods had fallen out. The correct order and positions were determined in part from an old photograph (Figure $976)$, in part from an analysis of the warp controls needed to create the pattern. Warp length 12 inches. 131

It seems that the loom at the time of acquisition had at least one heddle rod, probably more, inferring from the mass of yarns around the one heddle rod, and six rods. Also the warp control of the restored loom seems to be as follows and is analyzed only from the photograph since the specimen could not be examined.

The only literary reference to an archaeological double cloth loom is written by Joyce. ${ }^{132}$ The loom (Figure 98) is in the British Museum, dated from the Late Period, and found in the burial grounds in the Pacasmaya Valley, the loom has two heddle rods and one shed rod with the following positions:

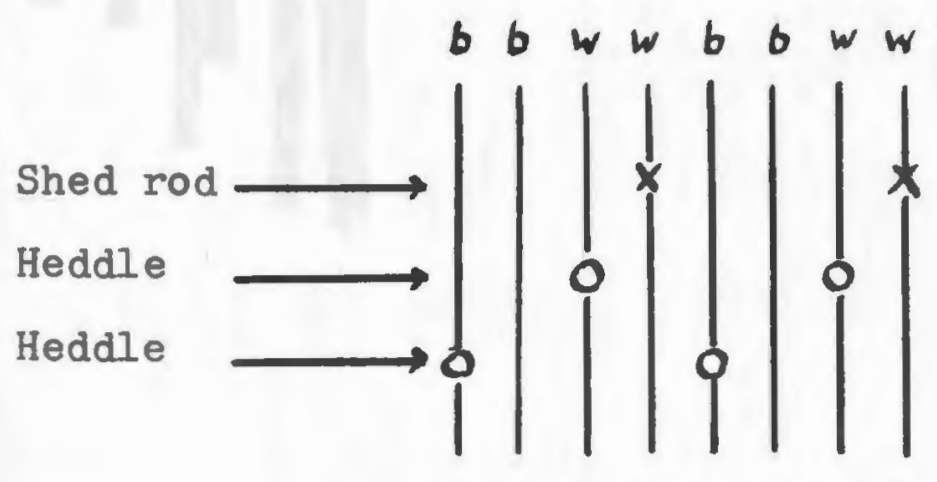

123456618

Figure 98. Warp control of loom. Described by Joyce. 


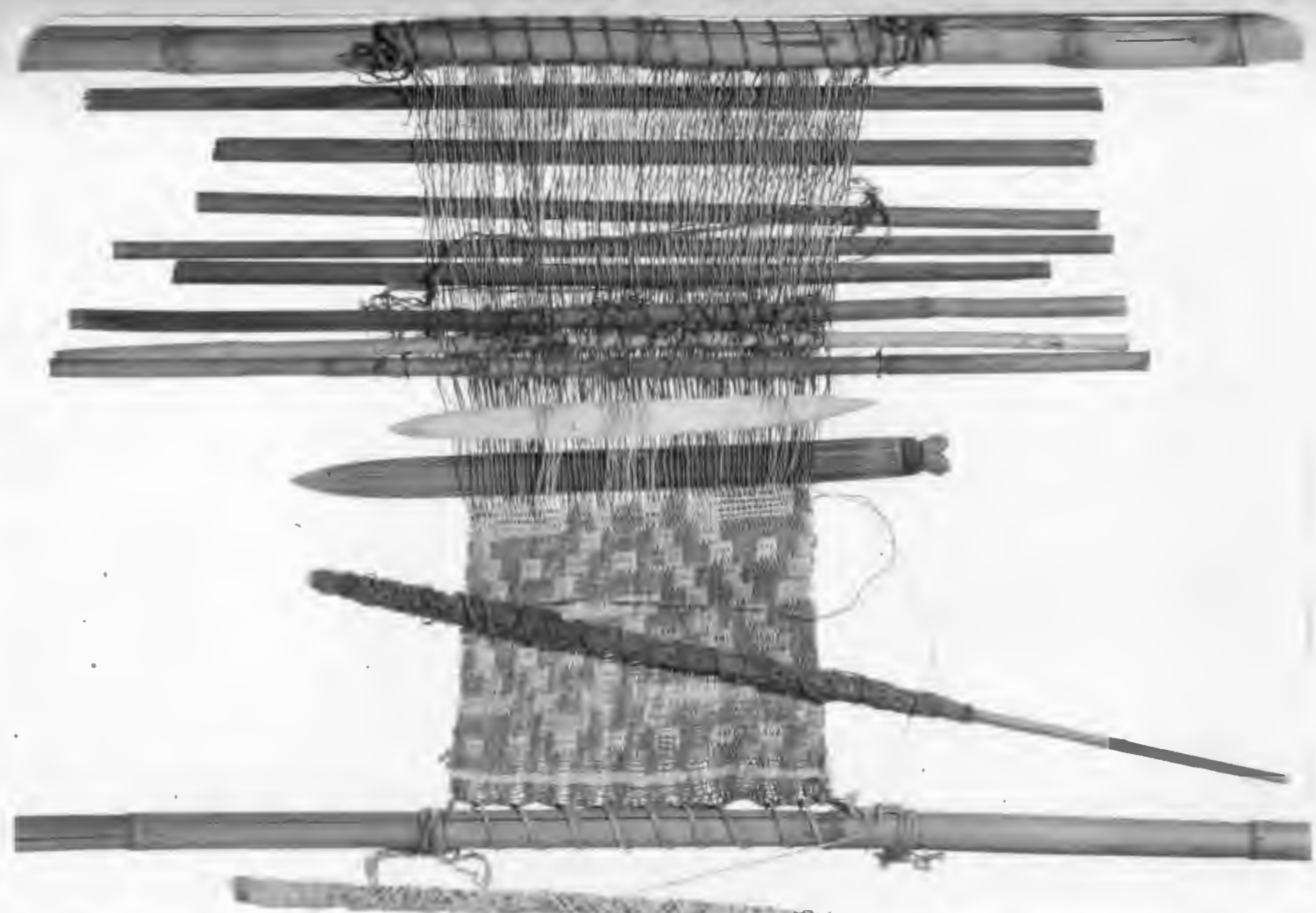

Figure 97. Double cloth $100 \mathrm{~m}$ restored in 1962. Beater and pattern stick added.

Source: Courtesy of the American Museum of Natural History, New York. \#B-7771. 


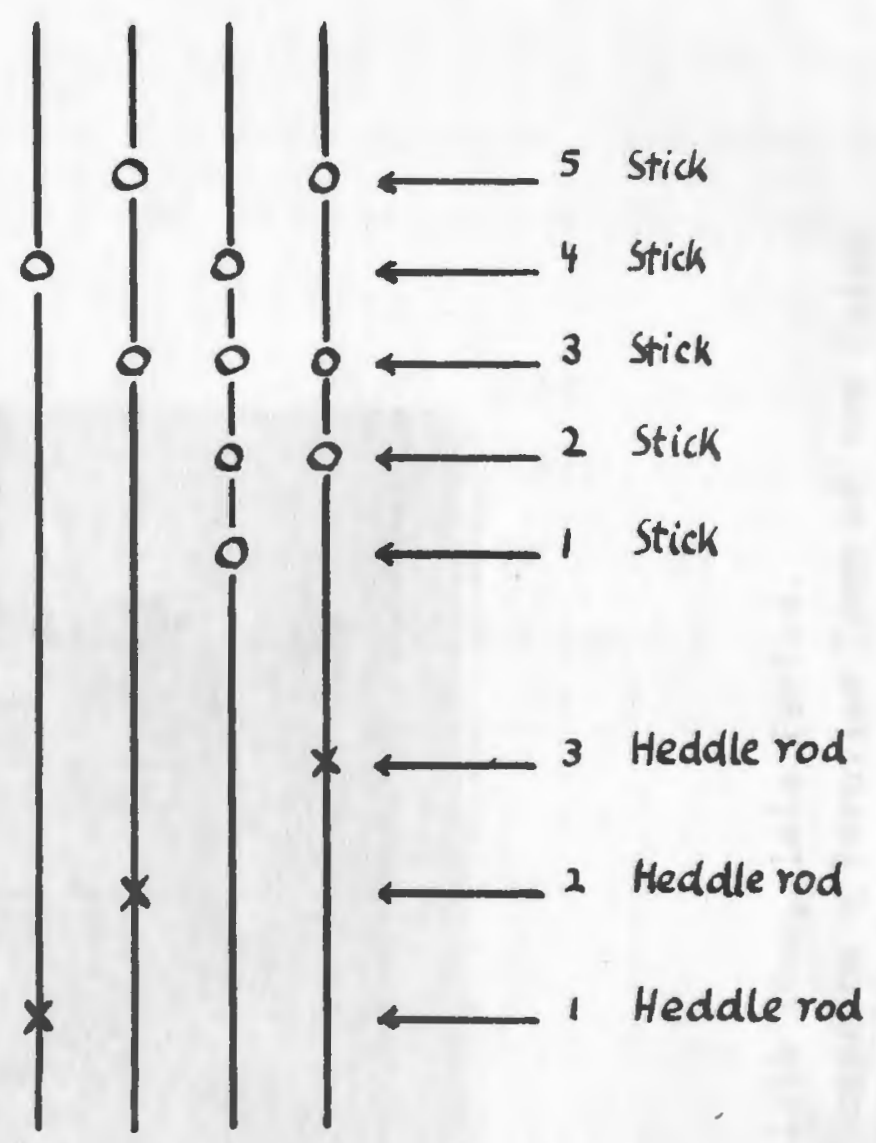

O yarn goes over stick

$x$ the heddle rod controls are assumed

Stick 1 functions as the shed rod, stick 4 and 5 are the lease sticks for plain weave, stick 2 raises the design warps and stick 3 opens the shed for weaving half of the dark yarnis as bottom layer.

Figure 97. Warp controls for \#B-7771.

Source: American Museum of Natural History. 


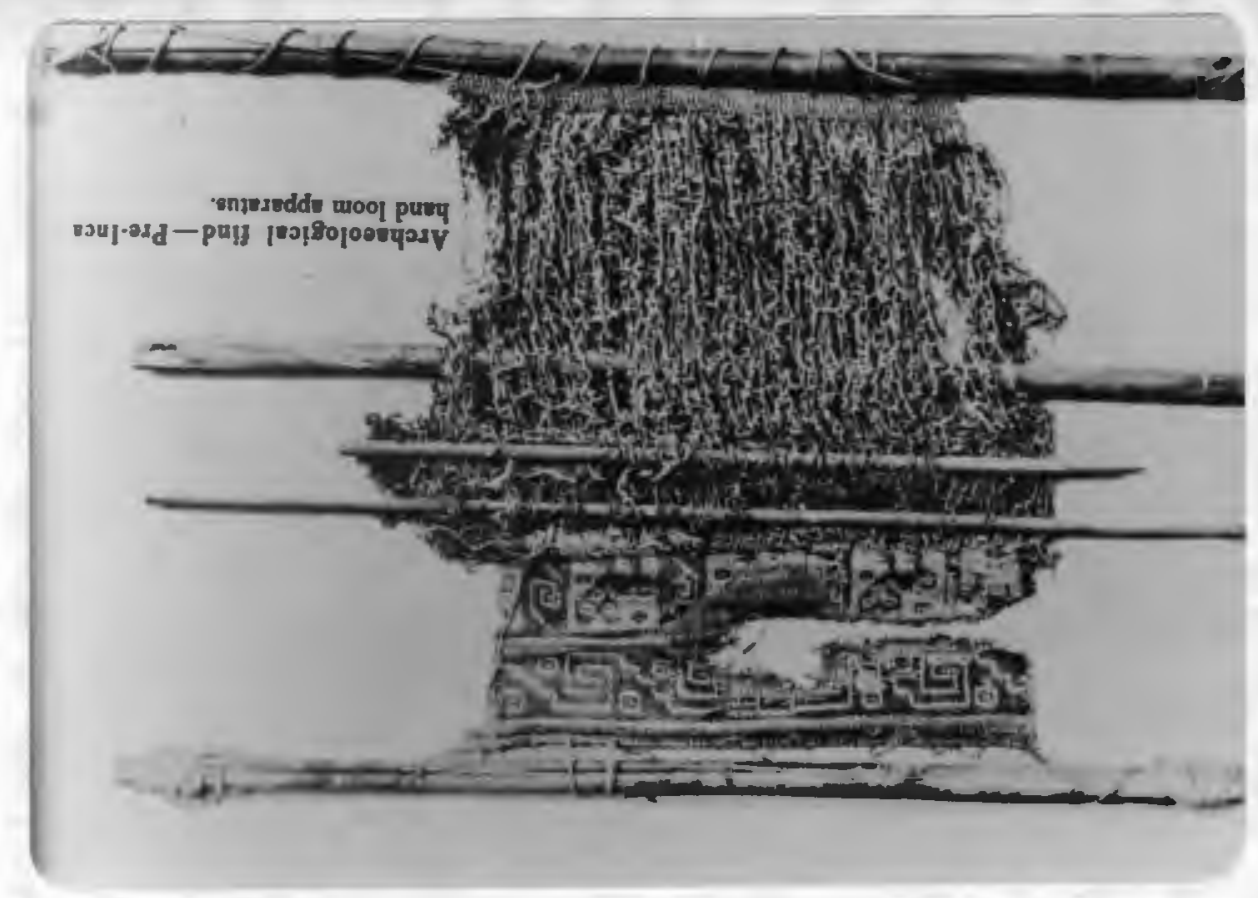

Figure 98 (Cont.). Double cloth loom, Late Period.

Sources: Thomas A. Joyce, "Notes on a Peruvian Loom of the Chima Period," Man, January, 1922.

Note: Photograph was taken from print in the Encyclopedia of Textiles, American Fabrics Magazine (Englewood Cliffs, New Jersey: Prentice-Hall, Inc.), 1972, p. 264. 
In his analysis, Joyce notes that a second shed rod is necessary to control the even warps of the brown warp pairs. But the second shed rod is not workable, and it should be a heddle rod instead. With this the warp control is the same as the Cora Indians use on their looms. And considering that the loom in the Amaho Museum had three heddle rods, in addition to the realization that this set up is very simple and easy to use, I believe that the Peruvians of the Late Period wove double cloth with three heddle rods and one shed rod.

With reference to technical aspects in weaving double cloth, it is obvious that it is easier to weave only the face fabric and to skip the weaving of the lower layer if the design does not require it or to weave less wefts in the lower layer. Salmon reports occurrences of the first among the Peruvian textiles in the Fine Arts Museum, Boston. 133 King reports the second from the Paracas textiles as "the reverse side is never completely woven as the obverse." 134 The same was observed during this study.

Number 35.760, Museum of Art, Providence and \#40.168, Museum of Fine Arts, Boston are examples of the incomplete double cloth. In both fabrics the details within a design area are not reversed on the back. There seems to be a practice to weave the back areas minus two wefts which results in the floating warp yarns. Number 24.319, Museum of Fine Arts, 
Boston illustrates the other type of incomplete double cloth, where the wefts of the lower fabric were not woven. Number 52.349 is an example of a perfect double cloth (Museum of Art, Providence) (Figures 99-102).
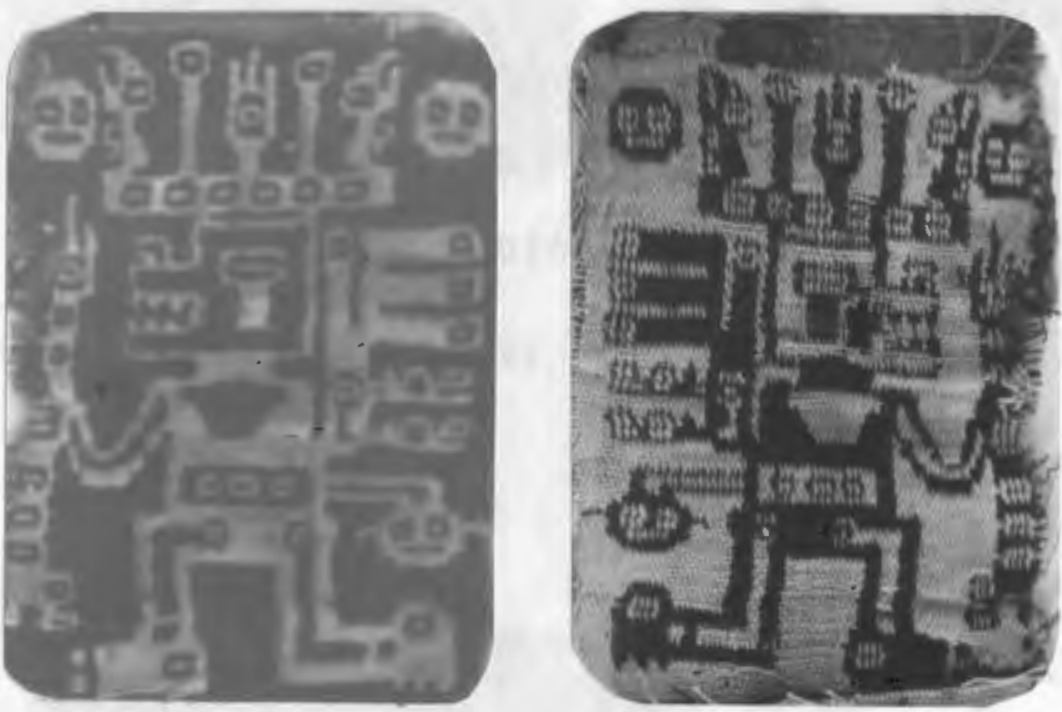

Figure 99. Incomplete double cloth. Source: Museum of Art, Providence, Rhode Island. \#35.760 


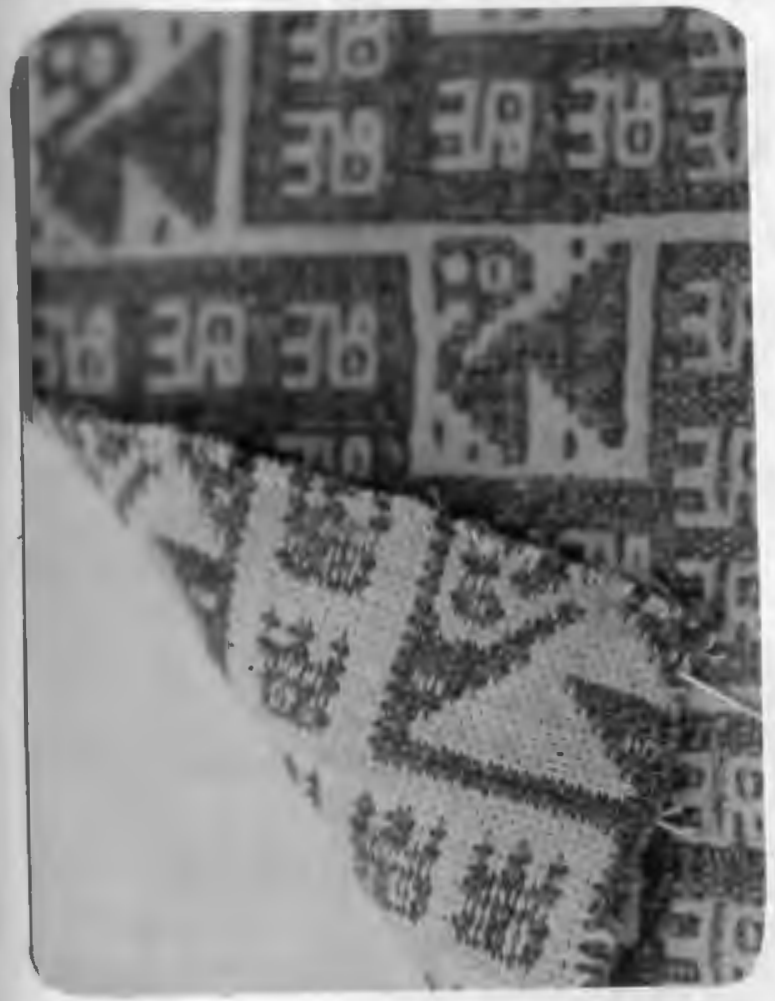

Pigure 100. Incomplete double cloth.

Source: Museum of Fine Arts, Boston, Mass. \#40.168

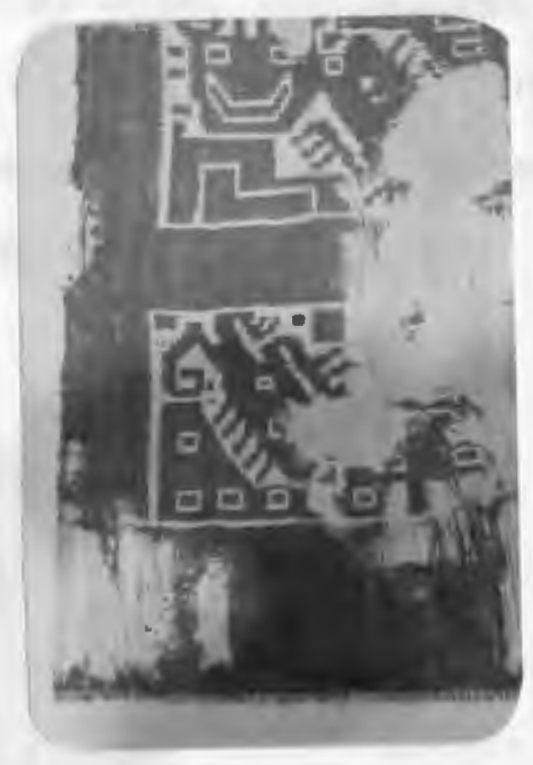

Figure 101. Incomplete double cloth.

Source: Museum of Fine Arts, Boston, Mass. \#24.319

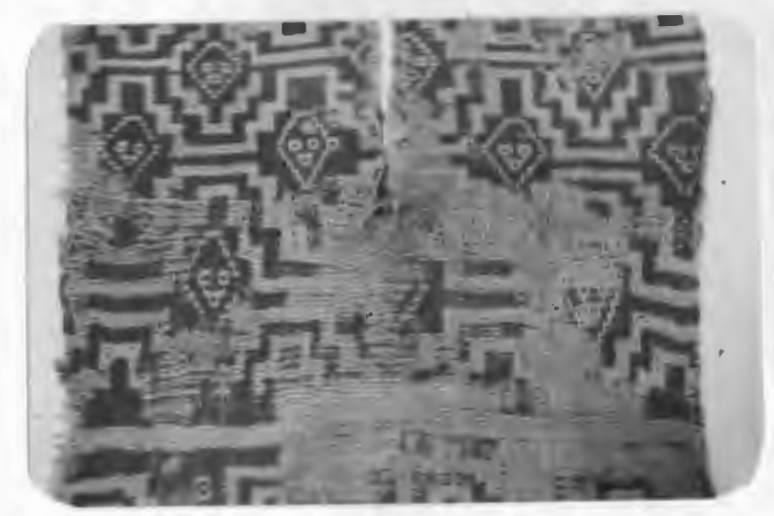

Figure 102. Complete double cloth, doll poncho. Source: Museum of Art, Providence, Rhode Island. $\# 52.349$ 
With the assumption that one heddle rod is lifted at one time or two, but only when these are placed close together as seen with the loom of the Cora Indians, then the weaving of \#78.92 (Museum of Fine Arts, Boston) can be explained. This 15 inch long and $2 \frac{1}{4}$ inch wide strip has four sections of double cloth alternating with plain weave Bections of paired yarns (Figure 103).

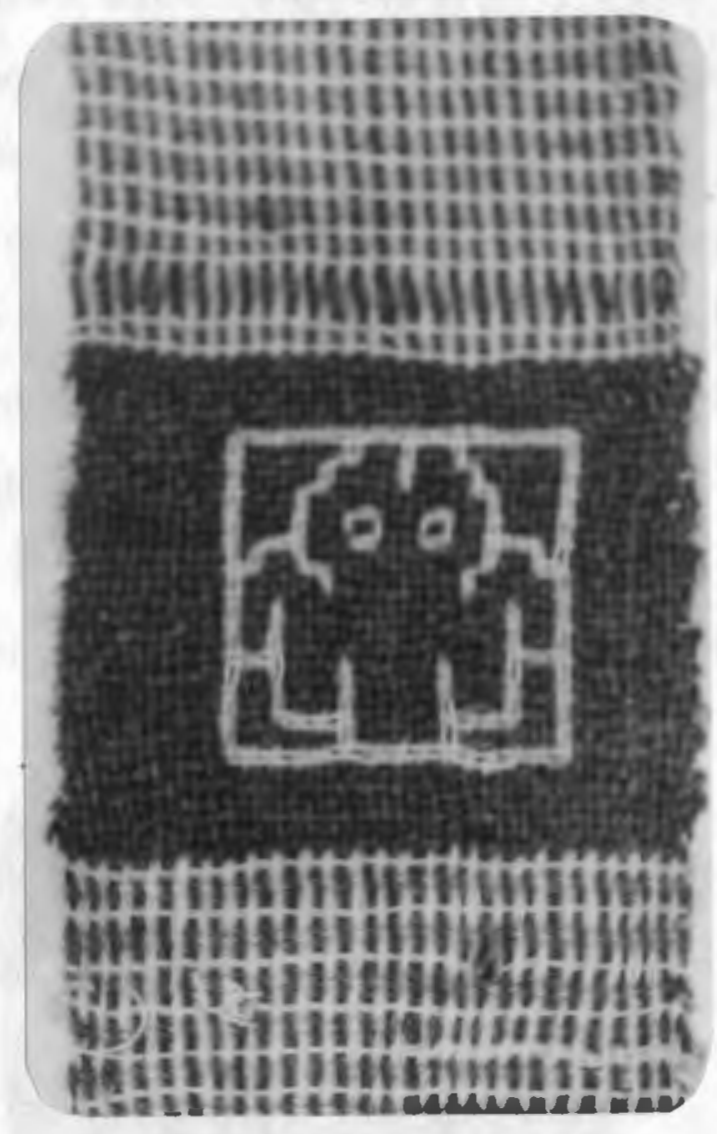

Figure 103. Double cloth and plain weave with paired warps. Source: Museum of Fine Arts, Boston, Mass. \#78.92 
It is difficult to explain the weaving of \#1921.49, Worcester Art Museum; \#38.030, Museum of Art, Providence and \#40.169, Museum of Fine Arts, Boston (Figures 104-106). All three textiles display double cloth, supplementary warp floats and plain weave with alternating pairs of blue and white yarns. The reverse side of \#1921.49 illustrates clearly how the warps float when not interwoven in the fabric. The warp control has to provide for plain weave. D'Harcourt notes that "supplementary warp and weft textiles form an introduction to the weaving techniques of double cloth."135 May be these pieces belong to this transition period where double cloth was woven with pick-up sticks and a plain weave warp control. The suggested date for \#40.169 is Late Intermediate period, and for \#38.030 late Nazca, about the 14th century. And this is also the time of the double cloth loom with two and presumably three heddle rods. Only a perfect intact specimen would provide an answer.

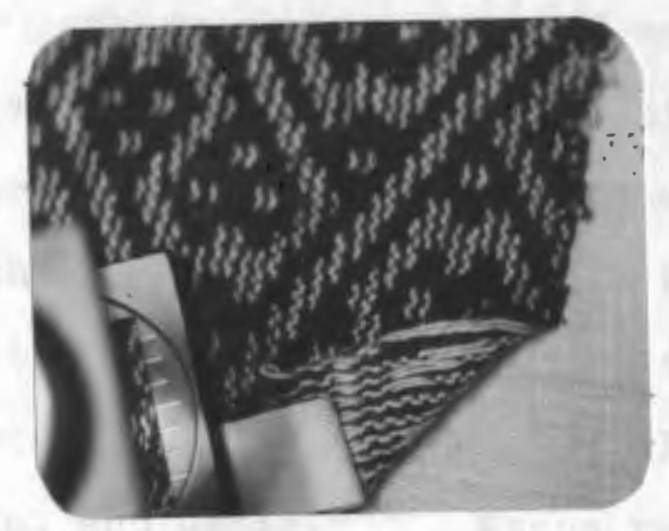

Tigure 104. Supplementary warp floats (face and reverse side of fabric).

Source: Worcester Art Museum. $\# 1921.49$. 


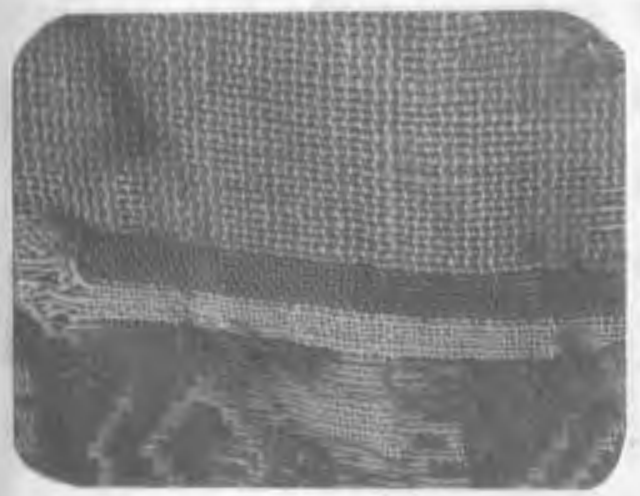

Figure 105. Double cloth and supplementary warp floats.

Source: Providence Museum of Art. $\# 38.030$

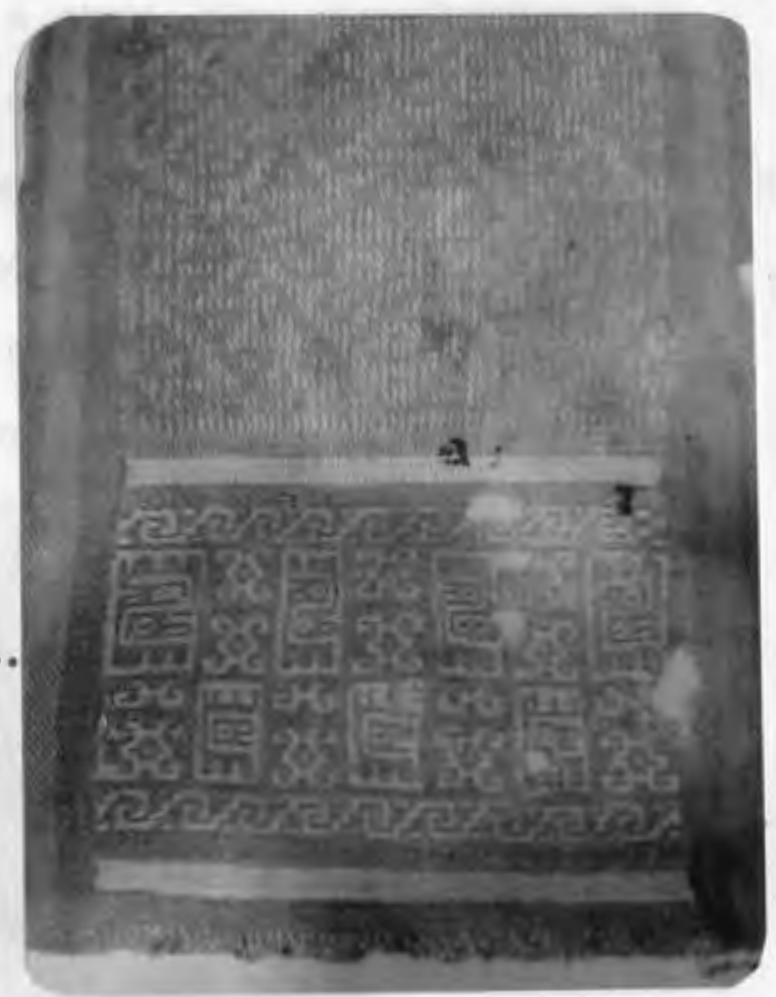

Figure 106. Double cloth, plain weave, supplementary warp floats.

Source: Museum of Fine Arts. \#40.169

Other pattern applications of multiple cloth include the tubular weavings woven with a continuous weft. Additional pattern warp yarns are carried within the tube and brought to the outside when needed in the design. The finished product is a flat strap which was often used in Inca times for coca bag straps and "is still made in parts of Peru, Bolivia, and Chile."136 Cason reports that in Bolivia four heddles are used for weaving. 137 With two pick-up sticks, 
half of the design and half of the background warps are raised and after weaving this shed, the warp layers are manipulated to produce the lower shed without further pick up. Number 91.564 is an example of the technique in a high warp count with the weft completely hidden, and \#91.58841 is an example of a double cloth with a square cloth count of several warp colors (Figures 107-108).

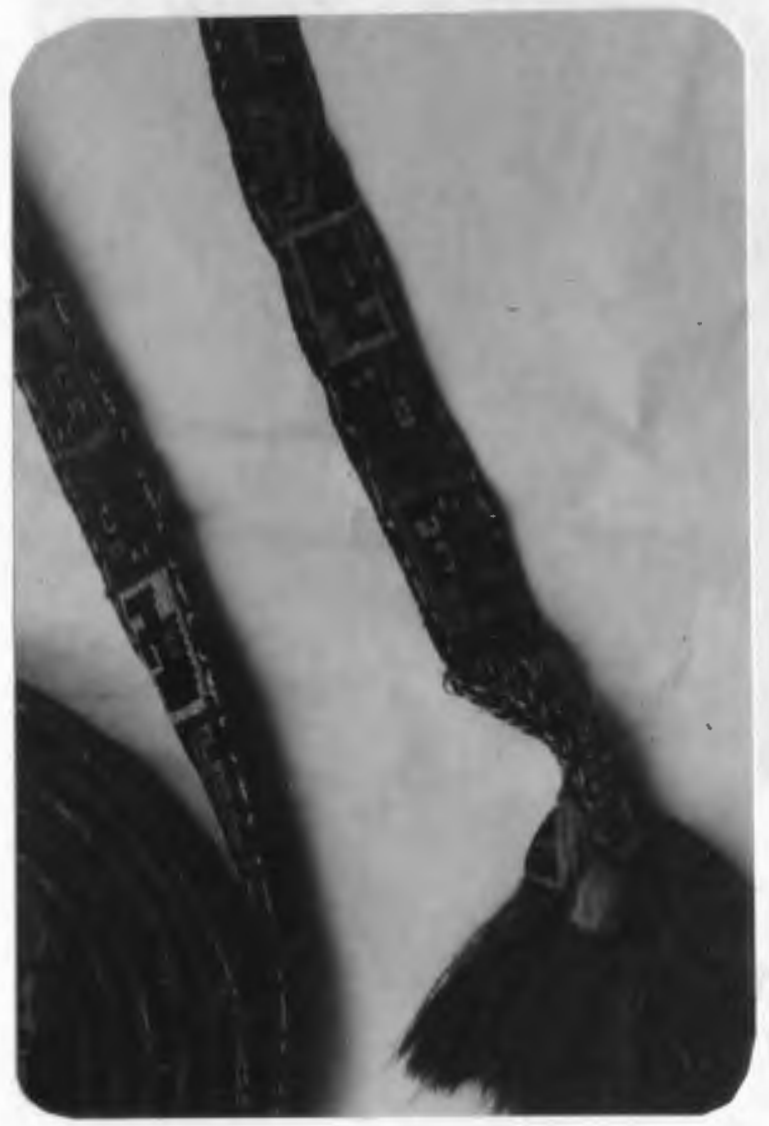

Figure 107. Warp-faced double cloth with continuous weft. Source: Textile Museum, Washington, D.C. $\# 91.564$

Note: Late Middle Horizon or early Late Intermediate Period. Colors: red, yellow, blue, green, white and brown. $15 \mathrm{~cm}$ wide 


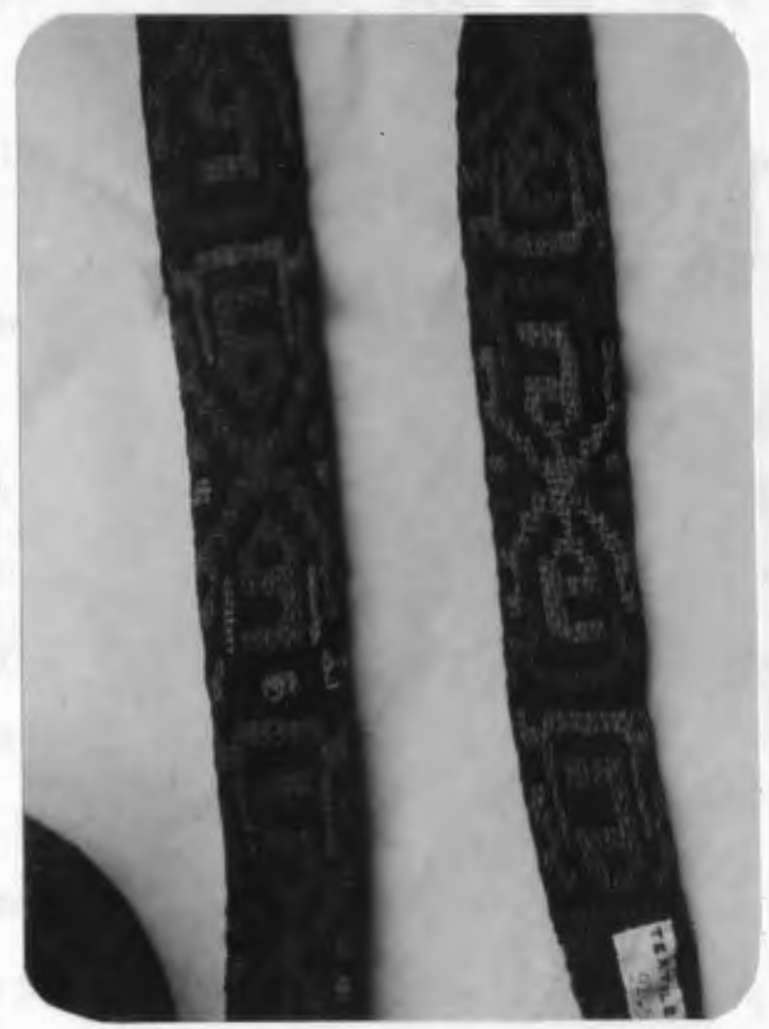

Figure 108. Double cloth with multiple warp.

Source: Textile Museum, Washington, D.C. \#91. 58841

Note: Probably from the South Coast, late Nazca style. Dated from late Early Intermediate or Middle Horizon. Wool yarns with square count.

Colors: yellow, red, green in design and blue in background. 
A further application used three sets of warps and wefts which led to weaving triple cloth. The technique was fairly common during Paracas times. The fabrics were narrow, "all, without exceptions, are green, yellow and dark brown in color."138 Made of wool they were used for borders on garments. By weaving them alongside the garment and sharing a common loom string and heading cord, only the sides had to be sewn up at the end. The result was a reversible garment with a two color effect in the border.

Number 47.1084, Museum of Fine Arts, Boston is 2 inches wide, $4 \frac{1}{2}$ inches long with cut edges on all four sides and dates from the Early Horizon. Colors are purple, green and tan. Only green and tan are woven on the reverse side. The triple cloth is incomplete, weft areas between design units are not woven (Figure 109).

In summary there seemed to have been no more than four major warp divisions used, excluding all pattern sheds. This is noted by Eisleb for the collection in the Museum fuer Veelkerkunde, Berlin, by Skinner for the American Museum of Natural History, by this survey for the limited samples which were researched and by the account on Bolivian Highland weaving, that "flexibility in design and weave structure is achieved by hand picking from the simple two-shed arrangement of a string heddle and a shed rod or loop."139 It continues that up to four heddles are used in the Bolivian Highlands. 


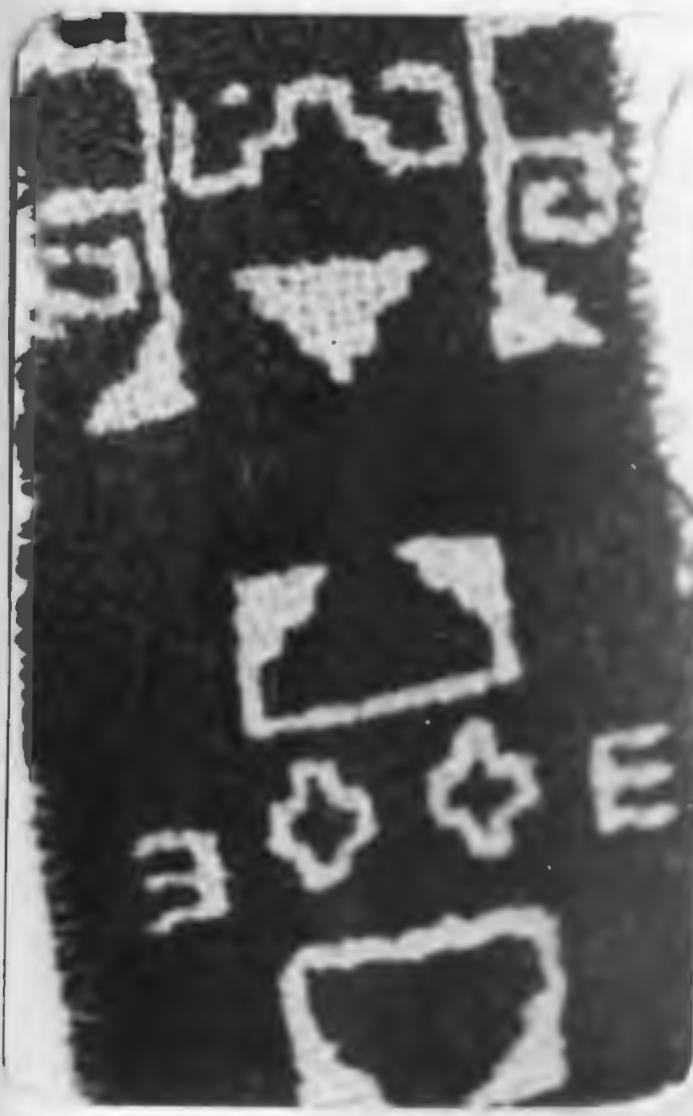

Face

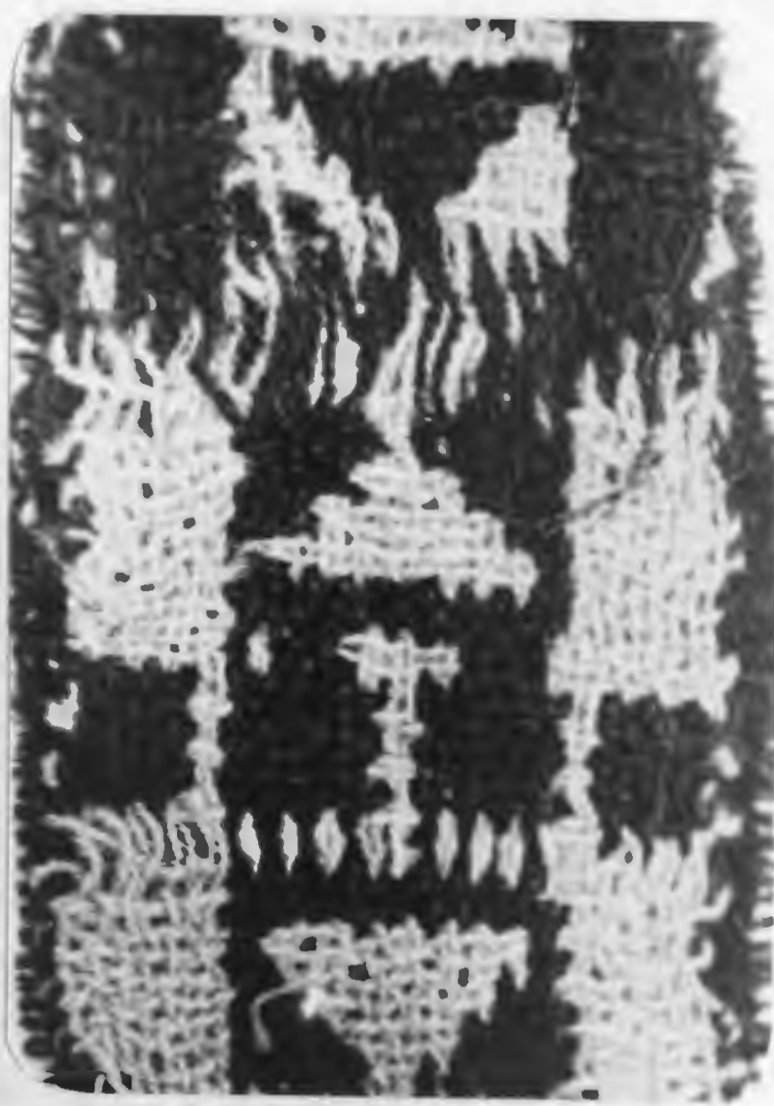

Reverse

Figure 109. Triple cloth.

Source: Museum of Fine Arts, Boston, Mass. $\# 47.1084$

All the heddle rods on looms with more than four major warp divisions prove to be, at closer examination, pattern heddle rods. Here under this category the number could be limited only by the finger dexterity of the weaver. Figure 110 is one example--of a two-shed arrangement with eight additional pattern heddle rods for weaving a diamond warp pattern. 


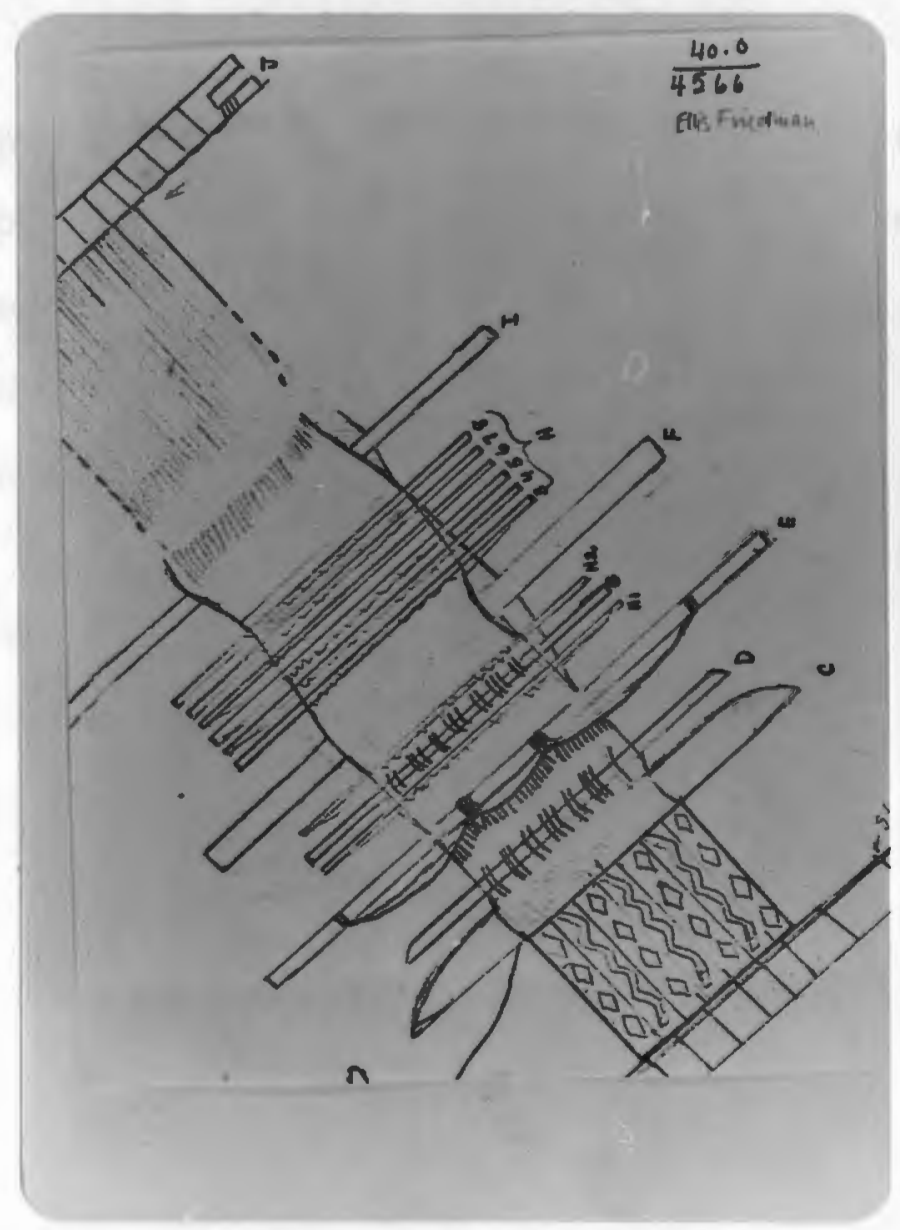

Figure 110. Warp pattern on loom with eight pattern-heddle rods and plain weave two-shed arrangement.

Bource: American Museum of Natural History, New York. $440.0 / 4566$ 
From the looms, which Schmidt listed that have four to five warp divisions, only a sketch survived World War 1I. It is recognizable that the three heddles and one shed rod belong together and the shorter stick must be a lease stick for the plain weave (Figure 111).

With this in mind it is most likely that all the patterned application of double cloth, twill, etc. were woven with pick-up sticks and the two-shed arrangement of the plain weave, until later when the multi-heddle system came into use.

Furthermore, this could be interpreted as a limitation of the loom that may have stopped explorations with twill weaves. 


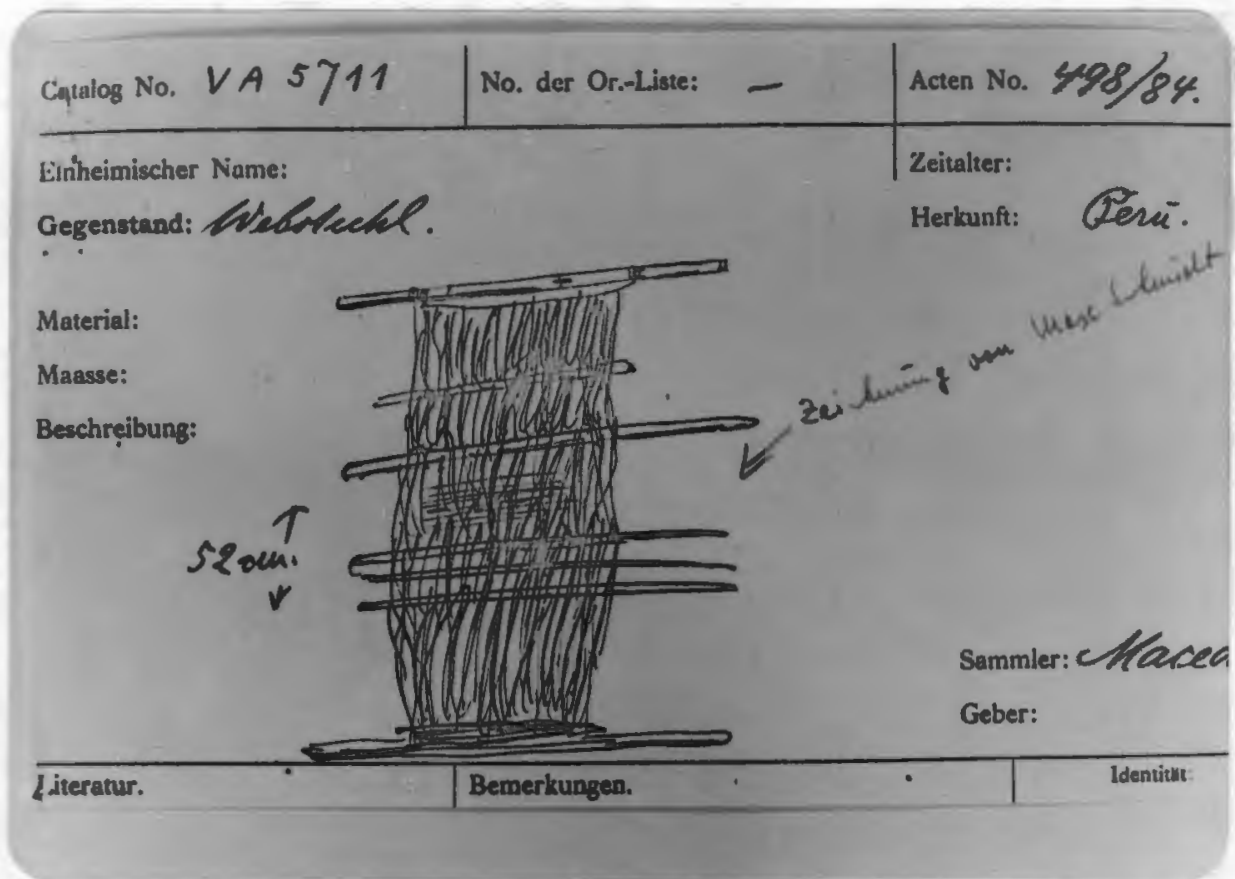

Figure 111. Catalogue Card VA 5711, Museum fuer Voelkerkunde, Berlin.

Note: Max Schmidt in Kunst and Kultur von Peru (p. 80) mentions this loom. Loom has three heddle rods plus shed rod and a warp division for plain weave. 


\section{SUMMARY AND CONCLUSIONS}

The actual weaving on the backstrap loom and the study of how and for what the loom was used during the Peruvian textile history reiterates what is already common knowledge . . . that the loom, simple in structure, is highly economical, easy to set up and to dismantle, flexible in application and a challenge to the weavers imagination.

The Peruvians, known for their great weaving skills which are based on uninterrupted experiences from the earliest times and on the production of immense quantities of textiles, exploited the freedom which is connected with the weaving without a confining reed. The garments had four selvages and were easily shaped just by a change in weft tension. The Peruvians crossed warp yarns or let them deflect to the right or left. They recognized the value of the flexible string heddle for a "mechanized" weaving of plain or alternating plain gauze. But there is no evidence that they employed the twin heddles as done in Guatemala for weaving brocades and twill. Only the counter heddle appeared on reconstructed double-cloth looms and this seems to be the application of one or few weavers. 
Above all the Peruvians mastered the medium fully. This mastery was coupled with a "continuous ingenuity for permutations of traditional ingredients, "140 which were early established in history and included a design repertoire of representational and geometric motifs, design conventions and an energetic color scheme. This ingenuity let them choose among a multitude of techniques by favoring some and neglecting others during the various periods. Moreover, they seemed to have had full control of the tochniques and they adapted to what may be limitations of the tool-methey used perfect yarns, generally overspun which, although it happens easily with spinning with a drop spindle, is necessary for weaving with a backstrap loom. In the later period, when weaving became more a concern of mass production, they preferred higher warp densities by using the warp yarns as self spacing devices. They mastered the interchange of warp and weft in several techniques and manipulated several layers of colored warps to produce reversible fabrics. Therefore, with regard to this full understanding of the medium, it is surprising that twill weaves did not lead to satin and other twill derivative weaves.

The study seemed to indicate that the loom has limitations which are connected with the loom set up, the absence of the reed and the heddle system. The setting of the warp control can pose a problem. It can be solved by planning the set up on the warpling board or by developing through weaving 
the wefts of the first repeat. The weaving with multiheddles can be of merit when heddle rods can be lifted simultaneously. It seems that the Peruvians worked only with one heddle rod at one time and with two when the design or background warp had to be lifted for weaving double cloth. The two heddle rods were placed close together.

The limitations to which the Peruvians adapted with smooth yarns, high warp density and no further explorations in either weave structures can be recognized and circumvented, not by changing the backstrap loom into a harness loom but by simplifying and pre-planning the warp on the warping board and by suitable heddle rod arrangements.

The backstrap loom can be a challenge to the contemporary handweaver through explorations with loom shaping, gauze weaves, high density float weaves for textural effect--in other words the challenge to the weaver's imagination is to search for the unusual which the rigid and confined harness loom is not capable of doing. This is based on the absence of the reed and the flexibility of the string heddles. Therefore, any technical modification which would harness the heddles into rigid frames or introduce a warp spacer in front of the heddles would curtail this freedom.

The backstrap loom was the major loom of the ancient Peruvians and much can be learned through examining the textiles and techniques displayed on extant looms. Throughout this study, it became increasingly aware to this researcher 
what Nora Fisher writes ". . there is a lot of work to be done in the study of how backstrap looms are used, how the ancient Peruvians may have used them." 141 Hopefully this study contributed partly to this effort. 


\section{LIST OF FOOTNOTES}

1. Else Regensteiner, Art of Weaving (New York: Van Nostrand Reinhold Co., 1970), p. 174.

2. Larry Salmon, "Jack Lenor Larsen in Boston," Craft Horizon, Vol. 31 (April, 1971), 14-15.

3. Ina VanStan, The Fabrics of Peru (England: F. Lewis Publishers, 1966), p. 8.

4. Shirley Held, Weaving (New York: Holt, Rinehart and Winston, 1973), p. 209.

5. Harriet Tidball, Peru: Textiles Unlimited, Part I, Shuttle Craft Guild Monograph 25 (Lansing: Shuttle Craft Guild, 1968), p. 33.

6. Held, Weaving, p. 95.

7. H. Ling Roth, "Studies in Primitive Looms," Journal the Royal Anthropological Institute, Vol. 46 (1946), 299.

8. Verla Birrell, The Textile Arts (New York: Ehocken Books, 1973), p. 91.

9. Lila M. O'Neale, "Weaving," Handbook of South rican Indians, ed. by Julian H. Steward, Vol 5 (1963), 105.

10. Ibid., p. 107.

11. Ibid., p. 105.

12. Information supplied with Figure 8, Courtesy of the merican Museum of Natural History.

13. Edward Lanning, Peru before the Incas (Englewood Cliffs, N. J.: Prentice-Hall, Inc., 1967), p. 24.

14. Ibid., p. 20.

15. Anna H. Gayton, "The Cultural Significance of Peruvian Textiles: Production, Function, Aesthetics," Peruvian achaeology, ed. by John H. Rowe and Dorothy Menzel (Palo Alto: sek Publications, 1967), p. 275.

16. John H. Rowe and Dorothy Menzel, Peruvian Archaeology, plected readings (Palo Alto: Peek Publications, 1967), introduction. 
17. Ina Van Stan, The Fabrics of Peru, p. 9.

18. Ibid., p. 9.

19. Junius B. Bird and Joe Mahler, "America's Oldest Cotton Fabric," American Fabrics, No. 20, 74.

20. Lanning, Peru before the Incas, p. 95.

21. Ibid., p. 96.

22. Alden J. Mason, The Ancient Civilizations of Peru (Baltimore, Maryland: Penguín Books, rev. ed. 1968, reprint ed., 1973), p. 66.

23. Lanning, Peru before the Incas, p. 130.

24. Ibid., p.132.

25. Ibid., p. 132.

26. Ann Rowe, "Peruvian Costume: A Weaver's Art," The Wextile Museum, Washington, D.C., Exhibition (Summer, 1974), p. 6 .

27. Wendell C. Bennett and Junius B. Bird, Andean CulTre History (New York: American Museum of Natural History, $60)$, p. 193.

28. Ann Rowe, "Peruvian Costume: A Weaver's Art," p. 2.

29. Anna H. Gayton, Peruvian Archaeology, selected readings, $\mathrm{p} .285$.

30. Lila M. O'Neale and Alfred L. Kroeber, "Textile ads in Ancient Peru, I," University of California Publica$\mathrm{ns}$, in American Archaeology and Ethnology, Vol. 28, No. 2 (e8), p. 28.

31. Mary Elizabeth King, "Textiles and Basketry of the Paracas Period, Ica Valley, Peru" (unpublished Ph.D. dissertation, University of Arizona, 1965), p. 84.

32. Bennett and Bird, Andean Culture History, p. 259.

33. Ibid., p. 260.

34. M.D.C. Crawford, "Peruvian Textiles," Anthropological ors of the American Museum of Natural History, Vol. 12, 3 (1915), p. 77 . 
35. King, "Textiles and Basketry of the Paracas Period," pp. 99-100.

36. Mary E. King, Ancient Peruvian Textiles from the collection of the Textile Museum, Washington, D.C. (New York: The Museum of Primitive Art, 1965).

p. 32 .

37. O'Neale, "Textile Periods in Ancient Peru, I," 1928,

38. Ann Rowe, "A Heritage of Color, Textile Traditions of the South Coast of Peru," Textile Museum, Washington, D.C., exhibition (Summer, 1973), pp. 4-5.

39. Gayton, Peruvian Archaeology, p. 289.

40. Alan Sawyer, "Tiahuanaco Design," Textile Museum Journal, Vol. I, No. 2 (December, 1963), p. 29. p. 30 .

41. O'Neale, "Textile Periods in Ancient Peru, I," 1928,

42. Ina VanStan, "Did Inca Weavers Use an Up-right Loom?" The Junius B. Bird pre-Columbian Textile Conference, 1973, Mhington, D.C. (May, 1973), p. 21.

p. 78 .

43. King, "Textiles and Basketry of the Paracas Period,"

44. Max Schmidt, Kunst and Kultur von Peru (Berlin: Propylaen Verlag, 1929), p. 78.

45. Bennett and Bird, Andean Culture History, p. 265.

46. Hans D. Disselhoff, Daily Life in Ancient Peru (New York: McGraw-Hill, 1967), illustration of Inca weaving.

47. Thomas A. Joyce, "The Peruvian Loom in the ProtoChimu Period," Man, Vol. 21, No. 12, p. 178.

48. Lila M. O'Neale, "Textiles of the Paracas Caverns Necropolis," University of California Publications, in rican Archaeology and Ethnology, Vol. 39, No. 2, Berkeley (द) p. 151 .

49. Thomas A. Joyce, "Note on a Peruvian Loom of the Chimu Period," Man, Vo1. 22, p. 1.

50. Roth, "Studies in Primitive Looms," 1916, p. 300.

51. Personal communication. 
52. Official Museum Directory, 1973, American Association of Museums.

53. Personal communication.

54. Milica Skinner, "The Archaeological Looms from Peru in the American Museum of Natural History," Paper presented at Textile Conference on Museum Textiles, Textile Museum (April, 1974).

55. Junius B. Bird, "The Care and Conservation of Ethnological and Archaeological Backstrap Looms," Curator, Vol. 8, No. $2(1964)$, p. 110.

56. Rowe, "A Heritage of Color: Textile Traditions of the South Coast of Peru," p. 6.

57. Personal communication.

58. Personal research.

59. Roth, "Studies in Primitive Looms," p. 285.

60. Ibid., p. 285.

61. Lila M. O'Neale, Textiles of Highland Guatemala (Whshington, D.C.: Carnegie Institute of Washington, 1945), Fi fure 20.

62. Redwood, Backstrap Weaving of Northern Equator (Santa Cruz, Calif.: Loom Books, 1973), p. 7.

63. O'Neale, "Textiles of the Paracas Caverns and Necpopolis," p. 151.

64. O'Neale and Kroeber, "Textile Periods in Ancient Peru,I," p. 30.

65. Mary E. King, "Preliminary Study of a Shaped Textile from Peru," Paper No. 13, Workshop Notes, Textile Museum (1956), Figure 3.

66. O'Neale, "Textiles of the Paracas Caverns and Neropolis," p. 151.

67. Bennett and Bird, Andean Culture History, p. 268.

68. O'Neale, "Textiles of the Paracas Caverns and Necropolis," p. 151, reference to E. Yacouleff and J.C. Muelle UnFardo funerio de Puracas RMN 3:63-153, Lima (1934). 
69. O'Neale, "Textiles of Paracas and Necropolis," p. 151, reference to 0'Neale, "The Wide-Loom Fabrics of Nazca," in Essays in Anthropology in Honor of Alfred L. Kroeber, pp. 215-228.

70. Courtesy of American Museum of Natural History.

71. O'Neale, "Textiles of Paracas and Necropolis," p. 157, reference to Rebecca Carrison Chachot, La indumentaria en la antigua cultura de Paracas, WiraKocha, 1:37-46, Lima (1931).

72. Ibid., p. 152, reference to Seventy Third Report on the Peabody Museum of Archaeology and Ethnology, Harvard University (1938-1940).

73. Junius B. Bird and Louise Bellinger, Paracas Fabrics ad Nazca Needlework (Washington, D.C.: National Publishing ., 1954), p. 110 .

74. Skinner, "The Archaeological Looms from Peru in the American Museum of Natural History," 1974.

75. Personal communication.

76. Personal communication.

77. Donald and Dorothy Cordry, "Costume and Weaving of the Zoque Indians of Chiapos, Mexico," Southwest Museum, Paper 15, Los Angeles, Calif. (1941), Figure 5.

78. Lila O'Neale and Bonnie J. Clark, "Textile Periods in Ancient Peru, III: The Gauze Weaves," University of California Publication, in American Archaeology and Ethnology, V01. 40 , No. 4 , Berkeley (1948), p. 157.

79. Ibid., p. 157.

80. O'Neale, "Weaving," in Handbook of the South American Indian, p. 117.

81. O'Neale, "Textile Periods in Ancient Peru, I," Basic table: Frequencies of processes according to areas and periods.

82. O'Neale and Clark, "Textile Periods in Ancient Peru, III, " p. 154 .

83. Raoul D'Harcourt, Textiles of Ancient Peru and Their echniques (Seattle: University of Washington Press, 1974), 442.

84. Ibid., p. 43. 
85. Harriet Tidball, Peru: Textiles Unlimited Part II, Shuttle Craft Guild Monograph 26 (Lansing: Shuttle Craft Guild, 1969), p. 16.

86. Bird and Bennett, Andean Culture History, p. 280.

87. Junius B. Bird, "Shaped Tapestry Bags from the Nazca Ica Area of Peru," Textile Museum Journal, Vol. 1, No. 3 (1964), 1 .

88. Ibid., p. 5.

89. Ibid., p. 5.

90. Mary E. King, "A Preliminary Study" of a Shaped Textile from Peru," Workshop Notes, Paper No. 13, Textile Museum, shington, D.C., 1956.

"Additional Examples of Shaped Textiles from Peru," supplement to Workshop Notes, Paper No. 13, Textile Museum (June, 1958).

91. Bennett and Bird, Andean Culture History, Figure 56.

92. King, "Additional Examples of Shaped Textiles from Peru," p. 2.

93. Bird, "Shaped Tapestry Bags from the Nazca Ica Area of Peru," p. 6.

94. Ibid., p. 6.

95. Gosta Montell, Dress and Ornaments in Ancient Peru (Goteborg: Elanders Boktryckeri Aktiebolag, 1929), p. 169.

96. Personal communication, Ann Rowe informs about two forms of interlock over a key weft, one between two warp yarns and the other around one warp yarn.

97. Bird, "The Care and Conservation of Ethnological and Fchaeological Backstrap Looms," Figure 5.

98. VanStan, The Fabrics of Peru, Figure 37.

99. Personal communication.

100. Alan R. Sawyer, "Tiahuanaco Tapestry Design," Textile hseum Journal (December, 1963), Vol. 1, No. 6, 27.

101. Ina VanStan, "Six Bags with Woven Pockets from preColumbian Peru," Nawpa Pacha, Institute of Andean Studies, No. 7-8 (1969-1970), Berkeley, p. 17 . 
102. O'Neale and Clark, "Textile Periods in Ancient Peru, III: The Gauze Weaves," p. 160-64.

103. Ibid., p. 185.

104. Ibid., p. 163.

105. King, "Textiles and Basketry of the Paracas Period, Ica Valley, Peru," Figure 26.

106. Irene Emery, The Primary Structures of Fabrics (Washington, D.C.: The T'extile Museum, 1966), p. 92.

107. Junius B. Bird, "Appendix; Textile Notes," in Cultural Stratigraphy in the Viru Valley, Northern Peru, ed. by William Duncan Strong and Clifford Evans, Jr. (New York: Columbia University Press, 1952), p. 359.

108. Ibid., p. 359.

109. Lila M. O'Neale, "Mochica (Early Chimu) and Other Paruvian Twill Fabrics," Southwestern Journal of Anthropology, Vol. 2, No. 3, 269-94.

110. Ibid., p. 269.

111. Ibid., p. 283.

112. O'Neale, Textiles of Highland Guatemala, p. 71.

113. O'Neale, "Mochica (Early Chimu) and Other Peruvian twill Fabrics," p. 279.

114. Rowe, "Peruvian Costume: A Weaver's Art," p. 4.

115. Sandra Harner, "An Early Intermediate Textile Pequence from Ancon, Peru," abstract from The Junius B. Bird pre-Columbian Textile Conference, 1973, Washington, D.C., p. 12.

116. Personal communication.

117. Ina Vanstan, Textiles from beneath the Temple of chacamac, Peru (Philadelphia: University of Pennsylvania, और, p. 32 .

118. O'Neale, "Mochica (Early Chimu) and Other Peruvian Twill Fabrics," p. 290.

119. Ibid., p. 289. 
120. Emery, The Primary Structures of Fabrics, p. 108.

121. Bird, "Appendix: Textile Notes," in Cultural tratigraphy in the Viru Valley, Northern Peru, p. 360.

122. Mason, The Ancient Civilization of Peru, p. 256.

123. Marjorie Cason and Adale Cahlander, "Bolivia Highland Weaving," Shuttle, Spindle, Dyepot, Handweaver's Guild of America, No. 22 (Spring, 1975), p. 5.

124. Personal communication with Dr. Junius B. Bird.

125. Personal communication with Dr. Ina VanStan.

126. Ibid.

127. Personal communication with Nora Fisher, Curator of Textiles, The Museum of International Folk Art, Museum of New Mexico, Santa Fe, New Mexico.

128. Harriet Tidball, The Double Weave, Plain and Patterned, Shuttle Craft Guild Monograph 1 (Lansing, Michigan: Shuttle Craft Guild, 1960), p. 4.

129. Personal communication with Dr. J. Bird, and Mrs. M. Skinner.

130. Catalogue entry of \#63.97 178013 tf, Metropolitan Nuseum of Art, New York.

131. Bird and Skinner, "The Care and Conservation of thnological and Archaeological Backstrap Looms," p. 118.

132. Joyce, "Notes on a Peruvian Loom of the Chimu Period," p.I.

133. Personal communication with Larry Salmon, Curator of Textiles, Museum of Fine Arts, Boston, Mass.

134. King, "Textiles and Basketry of the Paracas Period, Ica Valley," p. 162.

135. D'Harcourt, Textiles of Ancient Peru and Their Techniques, p. 42.

136. Bennett and Bird, Andean Culture History, p. 299.

137. Cason and Cahlander, "Bolivia Highland Weaving," p. 5 . 
138. King, "Textiles and Basketry of the Paracas Period, Ica Valley, Peru," p. 164.

p. 4 .

139. Cason and Cahlander, "Bolivia Highland Weaving,"

140. Gayton, Peruvian Archaeology, p. 289.

141. Personal communication. 


\section{BIBLIOGRAPHY}

Bennett, Wendell, and Bird, Junius B. Andean Culture History. New York: American Museum of Natural History, 1960.

Ard, Junius B. In Cultural Stratigraphy in the Viru Valley, Northern Peru. "Appendix 3, Textile Notes." Edited by William Duncan Strong and Clifford Evans, Jr. New York: Columbia University Press, 1952, pp. 357-60.

Bird, Junius B. "Shaped Tapestry Bags from the Nazca Ica Area of Peru." Textile Museum Journal, Vol. 1, No. 3, 1964, pp. 2-7.

Bird, Junius B., and Bellinger, Louise. Paracas Fabrics and Nazca Needlework, Third Century B.C. through Third Century A.D. Washington, D.C.: The Textile Museum, 1954.

Bird, Junius B., and Mahler, Joy. "America's Oldest Cotton Fabric." American Fabrics, No. 20, pp. 73-77.

Bird, Junius B., and Skinner, Milica. "The Care and Conservation of Ethnological and Archaeological Backstrap Looms." Curator, Vol. 8, No. 2, 1964.

Cordry, Donald and Dorothy. "Costume and Weaving of the Zoque Indians of Chiapos, Mexico." Southwest Museum, Paper 15, Los Angeles, California, 1941.

Crawford, M.D.C. "Peruvian Textiles." Anthropological Papers of the American Museum of Natural History, Vo1. 12, Part 3,1915 .

Cason, Marjorie, and Cahlander, Adale. "Bolivia Highland Weaving." Shuttle, Spindle, Dyepot (Spring, 1975), 2-4, 8.

Pisselfoff, Hans D. Daily Life in Ancient Peru. New York: McGraw-Hill, 1967.

D'Harcourt, Raoul. Textiles of Ancient Peru and Their Techniques. Seattle, Washington: University of Washington Press, 1974.

Mmery, Irene. The Primary Structures of Fabrics. Washington, D.C.: The T'extile Museum, 1966. 
Gayton, Anna H. "The Cultural Significance of Peruvian Textiles: Production, Function, Aesthetics." Peruvian Archaeology. Edited by John H. Rowe and Dorothy Menzel. Palo Alto, Calif.: Peek Publications, 1967.

Held, Shirley, Weaving. New York: Holt, Rinehart and Winston, 1973.

Harner, Sandra. "An Early Intermediate Textile Sequence from Ancon, Peru." The Junius B. Bird pre-Columbian Textile Conference, Washington, D.C., 1973.

Joyce, Thomas A. "The Peruvian Loom in the Proto-Chimu Period." Man, Vol. 21, No. 12, Art. No. 106, pp. 177-80.

Joyce, Thomas A. "Note on a Peruvian Loom of the Chimu Period." Man, Vol. 22, pp. 1-2.

King, Mary E. "Textiles and Basketry of the Paracas Period, Ica Valley, Peru." Unpublished Ph.D. dissertation, University of Arizona, 1965.

Xing, Mary E. Ancient Peruvian Textiles from the Collection of the Textile Museum, Washington, D.C. New York: The Museum of Primitive Art, 1965.

King, Mary E. "A Preliminary Study of a Shaped Textile from Peru." Paper No. 13, Workshop Notes, Textile Museum, 1956.

"Additional Examples of Shaped Textiles from Peru." Supplement to Workshop Notes, Paper No. 13, Textile Museum, June, 1958.

anning, Edward. Peru before the Incas. Englewood Cliffs, New Jersey: Prentice-Hall, 1967.

Mason, Alden J. The Ancient Civilization of Peru. New Jersey: Penguin Books, 1968.

Montell, Gosta. Dress and Ornaments in Ancient Peru. Goteborg: Elanders Boktryckeri Actiebolag, 1929.

O'Neale, Lila M. "Mochica (Early Chimu) and Other Peruvian Twill Fabrics." Southwestern Journal of Anthropology, Vol. 2, No. 3, Albuquerque, 1946, 269-94.

O'Neale, Lila M. "Textile Periods in Ancient Peru: II, Paracas Caverns and the Grand Necropolis." University of California Publications - - in American Archaeology and Ethnology, Vol. 39, No. 2, Berkeley, 1942, pp. 143-202. 
O'Neale, Lila M. "Weaving." Handbook of South American Indians. Edited by J.H. Steward. Bulletin 143, Vol. 5, pp. 97-138. Washington, D.C.: Bureau of American Ethnology, 1939.

O'Neale, Lila M. Textiles of Highland Guatemala. Washington, D.C.: Carnegie Institution of Washington, 1945.

O'Neale, Lila'M., and Clark, Bonnie Jean. "Textile Periods in Ancient Peru, III: The Gauze Weaves." University of California Publications, - in American Archaeology and Ethnology, Vol. 40, No. 4, Berkeley, 1948.

O'Neale, Lila M., and Kroeber, Alfred L. "Textile Periods in Ancient Peru." University of California Publications -in American Archaeology and EthnologY, Vol. 28, No. 2, Berkeley, 1928.

Redwood. Backstrap Weaving of Northern Equator. Santa Cruz, Calif.: Loom Books, 1973.

legensteiner, Else. Art of Weaving. New York: VanNostrand Reinhold Co., 1970 .

Roth, H. Ling. "Studies in Primitive Looms." Journal of the Royal Anthropological Institute, Vol. 46, 1916.

Rowe, Ann. "Peruvian Costume: A Weaver's Art." The Textile Museum, Washington, D.C., Exhibition Guide, Summer, 1974.

Rowe, Ann. "A Heritage of Color, Textile Traditions of the South Coast of Peru." Textile Museum, Washington, D.C., Exhibition Guide, 1973.

Rowe, John, and Menzel, Dorothy. Peruvian Archaeology. Selected readings. Palo Alto: Peek Publications, 1967.

Salmon, Larry. "Jack Lenor Larsen in Boston." Craft Horizon, Vol. 31, April, 1971.

Pawyer, Alan. "Tiahuanaco Design." Textile Museum Journal, Vol. 1, No. 2, December, 1963.

Schmidt, Max. Kunst and Kultur von Peru. Berlin: Propylaen Verlag, 1929.

skinner, Milica. "The Archaeological Looms from Peru in the American Museum of Natural History." Paper presented at Textile Conference on Museum Textiles, Textile Museum, April, 1974. 
Tidball, Harriet. The Double Weave, Plain and Patterned. The Shuttle Craft Guild Monograph No. 1. Lansing: Shuttle Craft Guild, 1960.

Tidball, Harriet. Peru: Textiles Unlimited, Part I. Shuttle Craft Guild Monograph No. 25. Peru: Textiles Unlimited, Part II. Shuttle Craft Guild Monograph No. 26. Lansing: Shuttle Craft Guild, 1969.

VanStan, Ina. The Fabrics of Peru. England: F. Lewis Publishers, 1966.

VanStan, Ina. "Did Inca Weavers Use an Up-right Loom?" The Junius B. Bird pre-Columbian Textile Conference, 1973.

VanStan, Ina. "Six Bags with Woven Pockets from pre-Columbian Peru." Nawpa Pacha. Berkeley, Calif.: Institute of Andean Studies, No. 7-8, 1969-70.

VanStan, Ina. Textiles from beneath the Temple of Pachacamac, Peru. Philadelphia, Pa.: University of Pennsylvania, 1967. 
APPENDIX A

BACKSTRAP LOOMS, GENERAL INFORMATION 

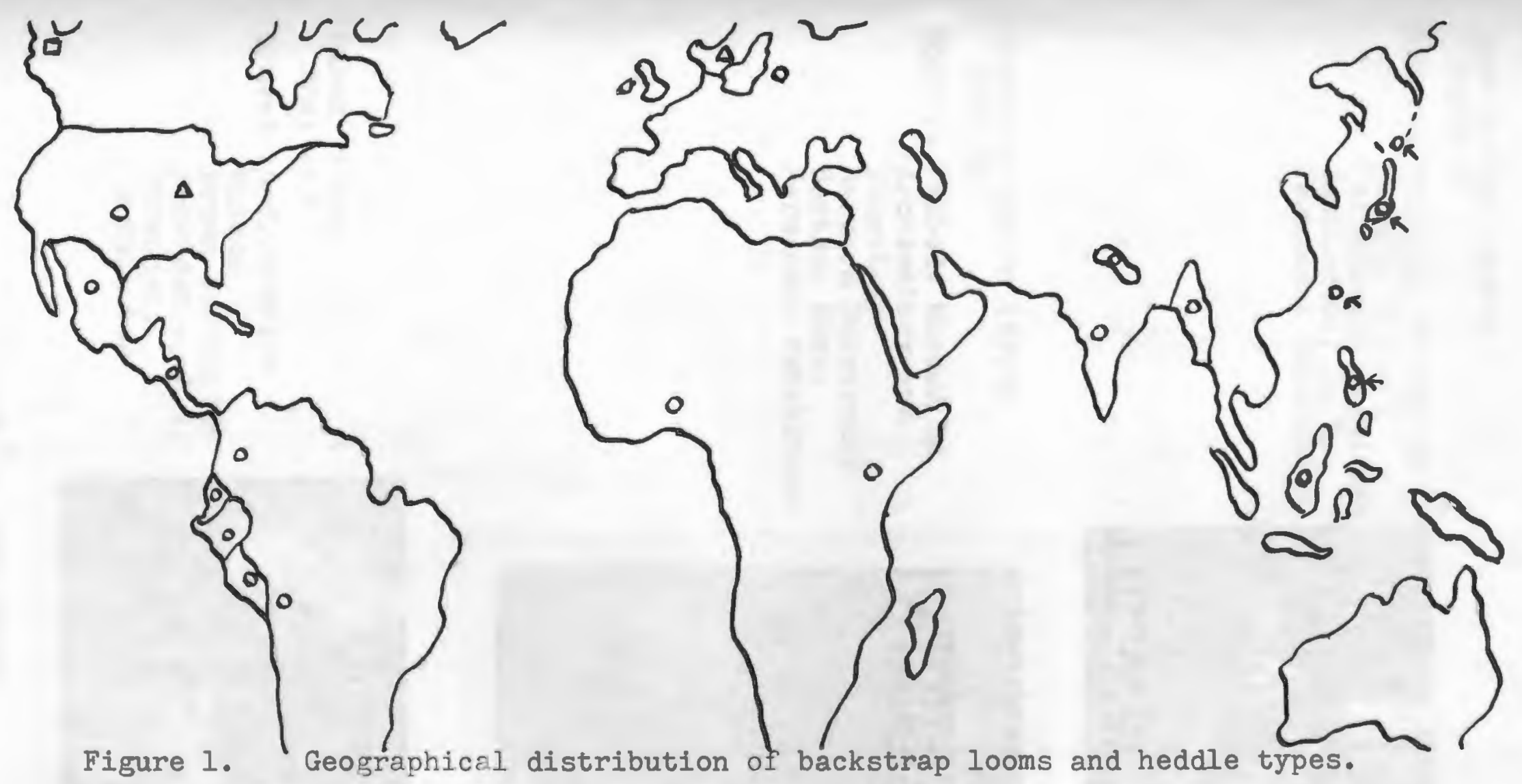
$\Delta$ Slot and eye heddle - Northern Europe, North America (Great Lake Regions)
D. Hole and board - Alaska (Yukon River)
- String heddle - America (Mexico, Guatemala, Ecuador, Bolivia, Peru)
- Asia (Japan, Tibet, India, Borneo, Philippine Island,
Formosa, Indonesia, Nepal)
- Africa

Source: H. Roth, "Studies in Primitive Looms," pp. 284-304; Birrell, The Textile Arts, p. 83. 
Zuni Indian (North America)

Source: National Museum of Natural History Smithsonian Institute Washington, D. C. Permanent Exhibition

Shononan Indian (North America)

Source: Peabody Museum of Archaeology and Ethnology

Harvard University Boston, Mass. Permanent Exhibition

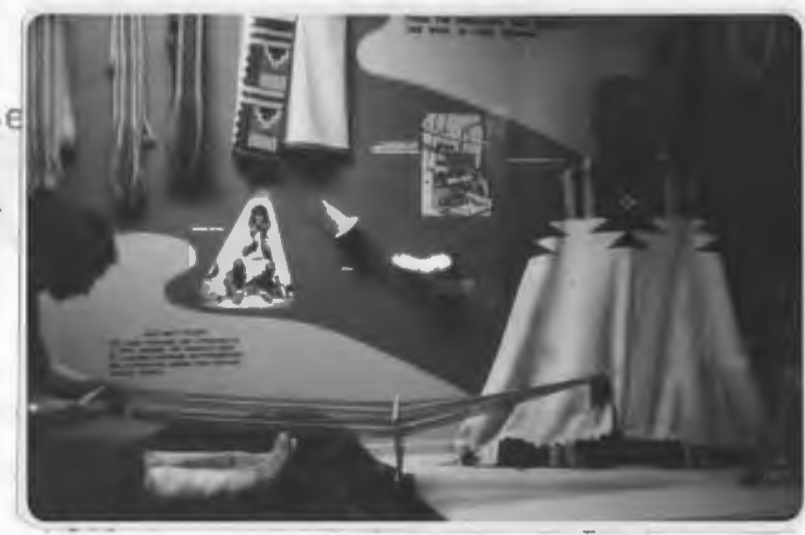

Karen Tribe, Thailand

Source: Haffenreffer Museum Brown University Providence, R.I. Permanent Exhibition
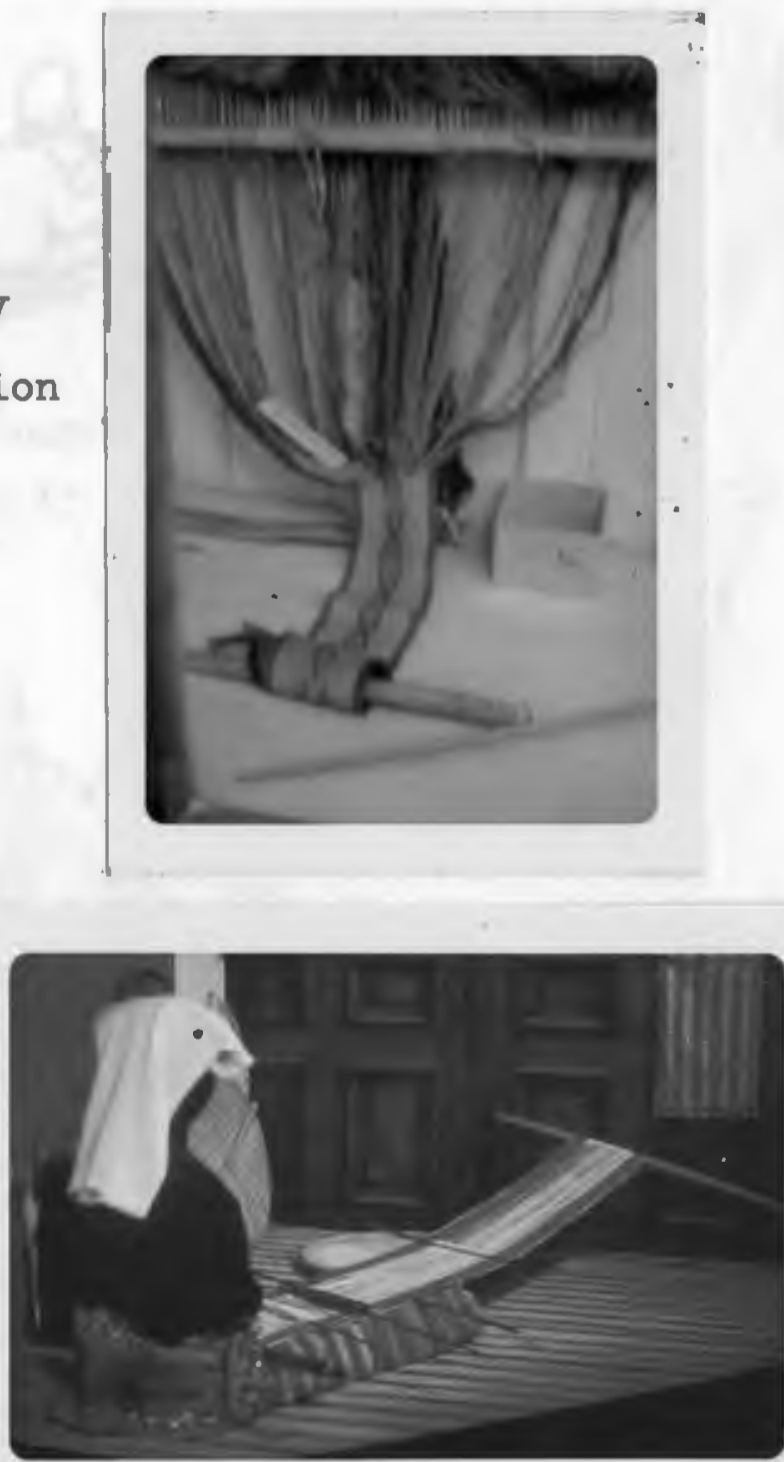

Figure 2. Loom types 


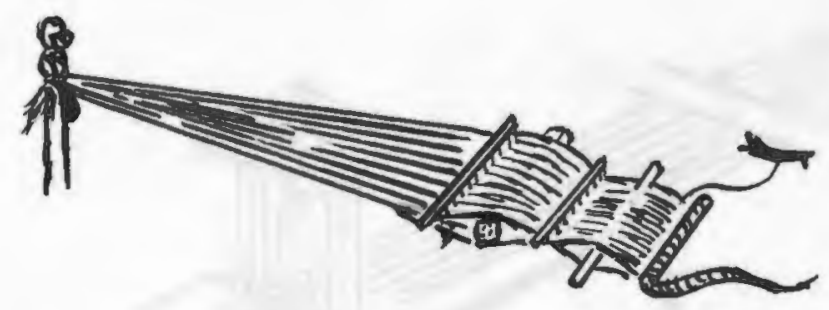

Ainu (Japan) after drawing by Ling H. Roth. Source: "Studies in Primitive Looms," Man, - Vol. 46, 1916, p. 293.

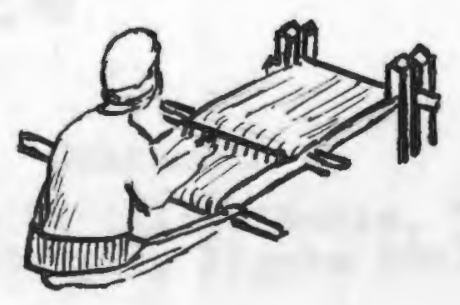

Ibans (Sea Dayaks of Southern Borneo)

Source: After drawing by Hose and McDouglass, 1912. Verla Birrell, Textile Arts, p. 92.

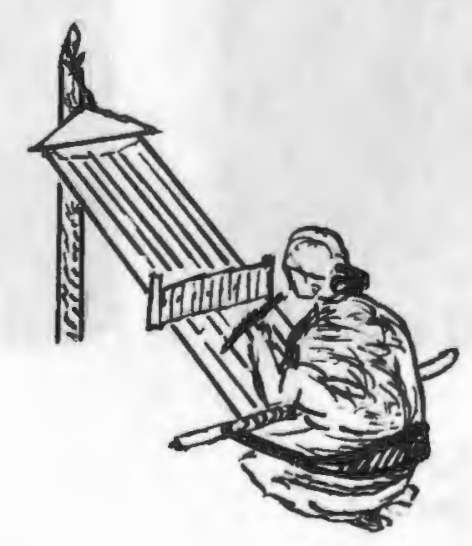

Potamatami Indian

Source: After drawing by Verla Birrell, Textile Arts, p. 95 .

Figure 2. Loom types 


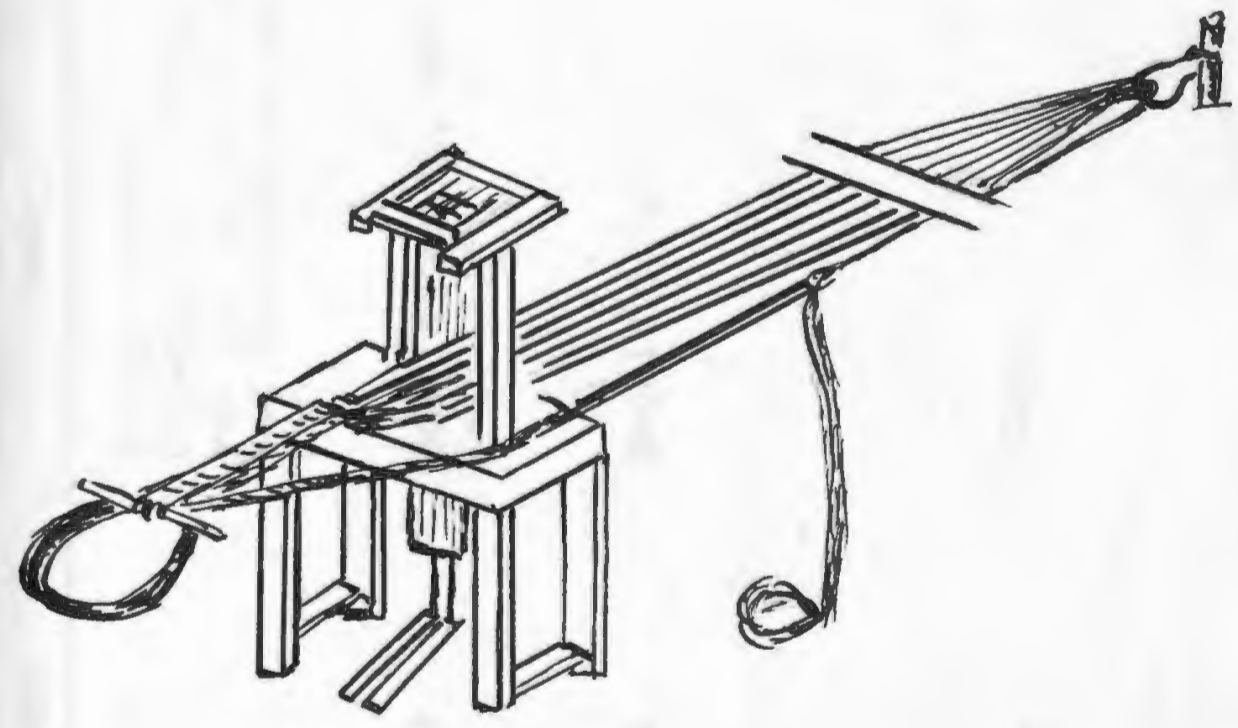

Guatemala

Source: After drawing by Lila O'Neale, Textiles of Highland, Guatemala, Figure 19h.

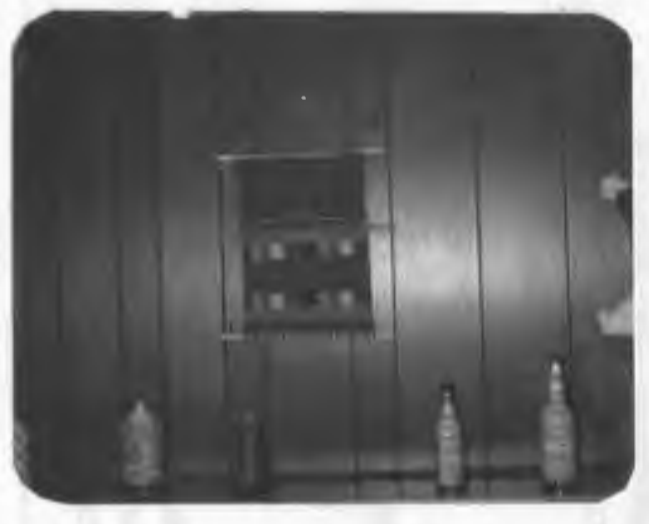

Guatemala

Owned by author

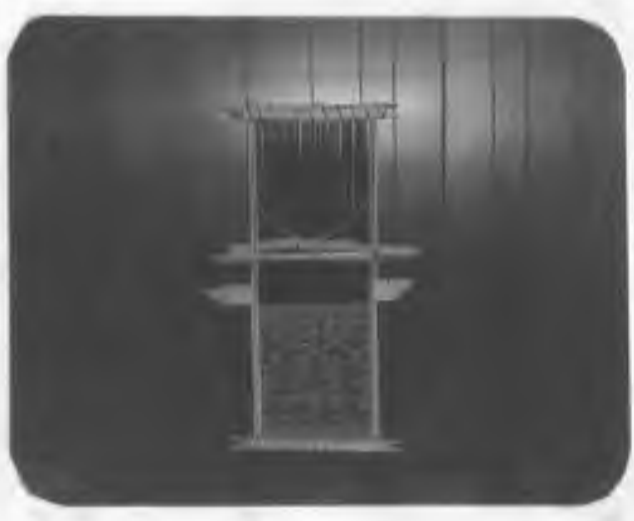

Chota loom, Peru Owned by author

$$
\text { Figure } 2 \text {-- Continued }
$$




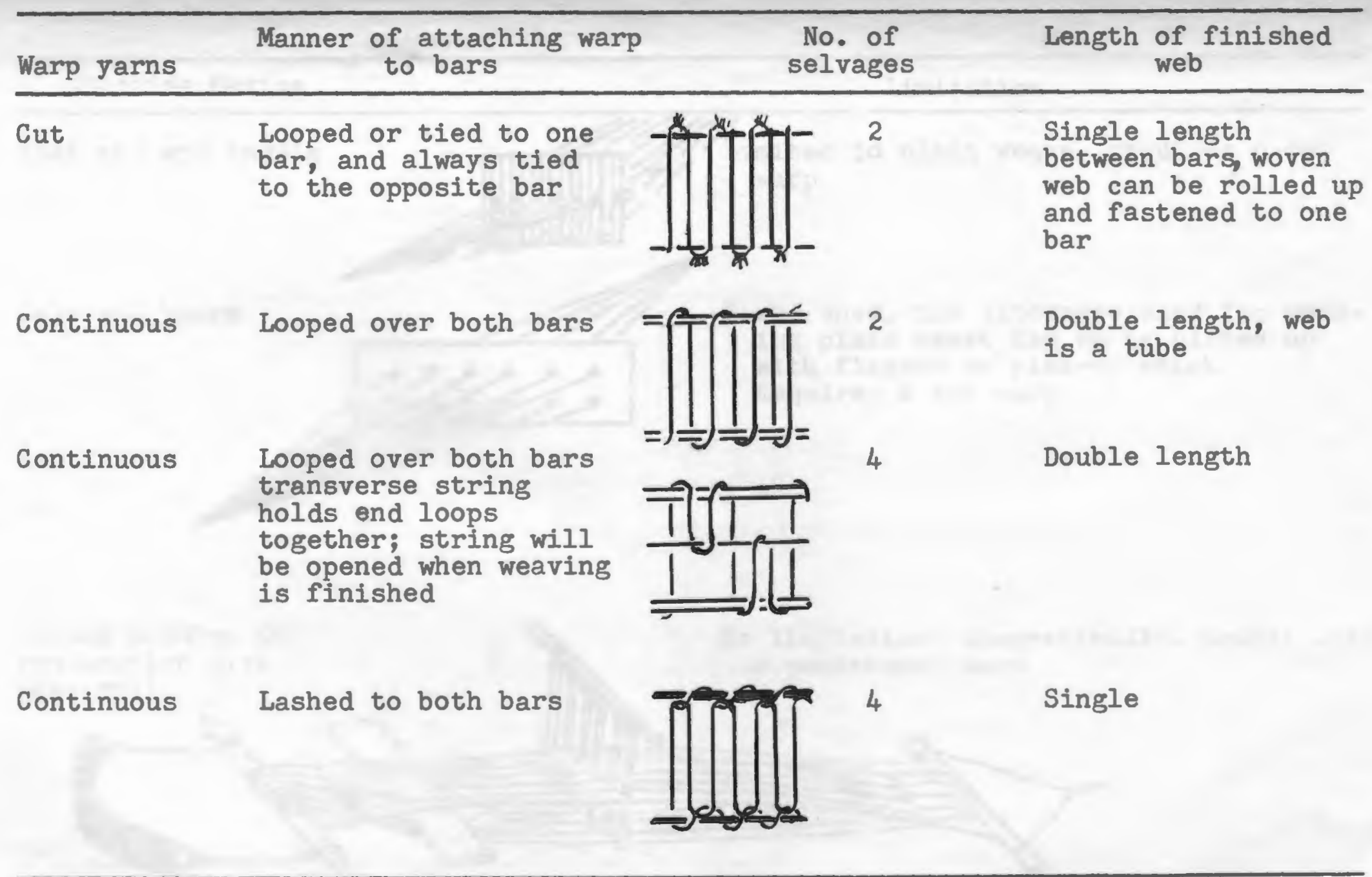

Figure 3. Warp arrangement and effect on the finished woven product. 


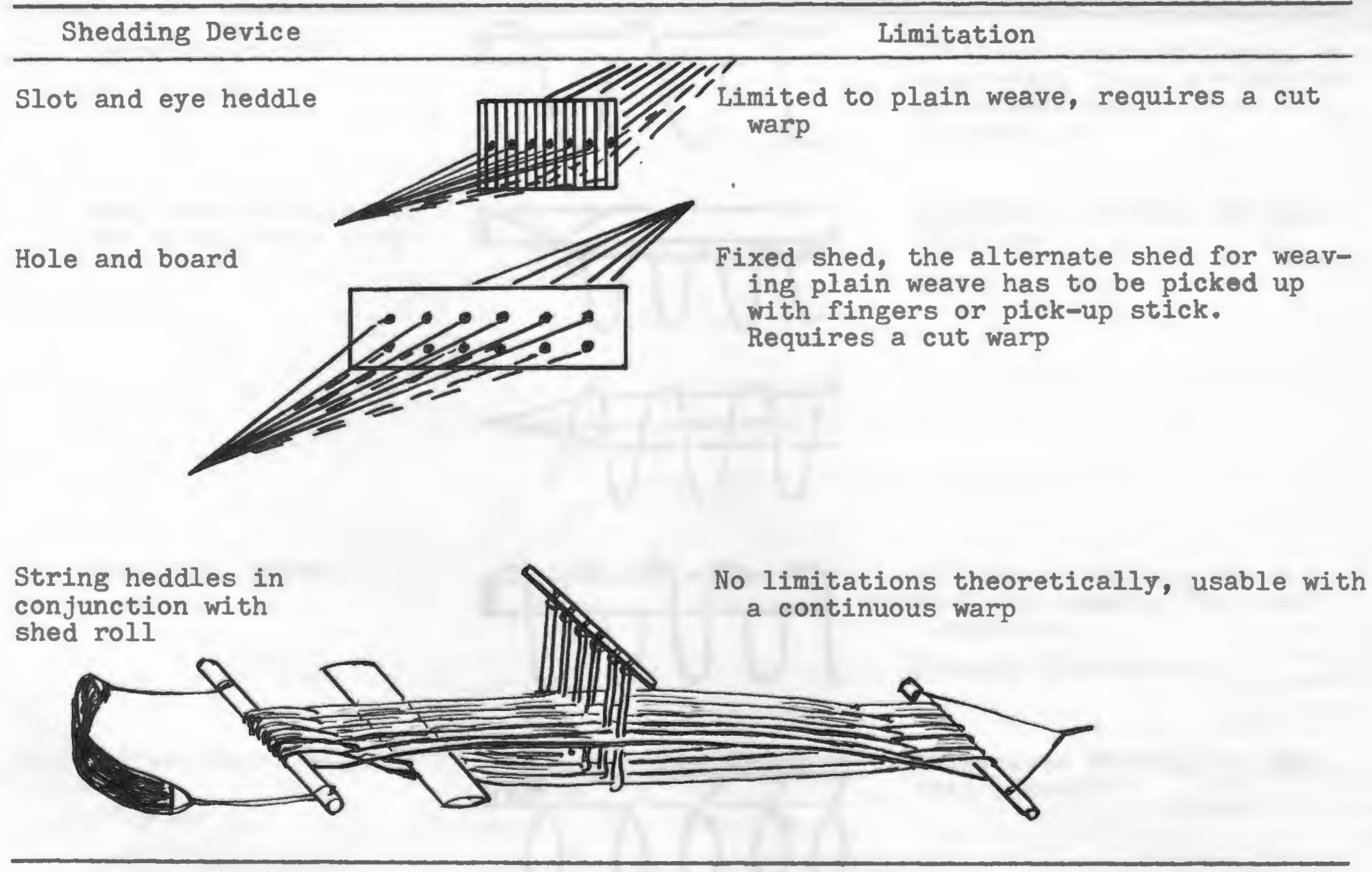

Figure 4. Shedding devices used with the backstrap looms. 
1. Spiral over rod

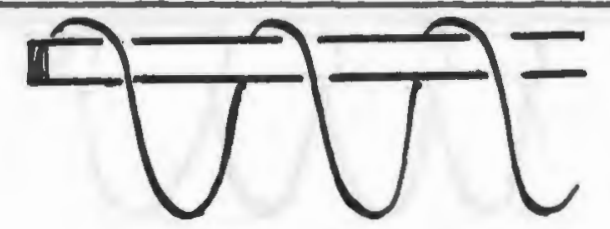

3. Over cord and tied to rod or multiple cord
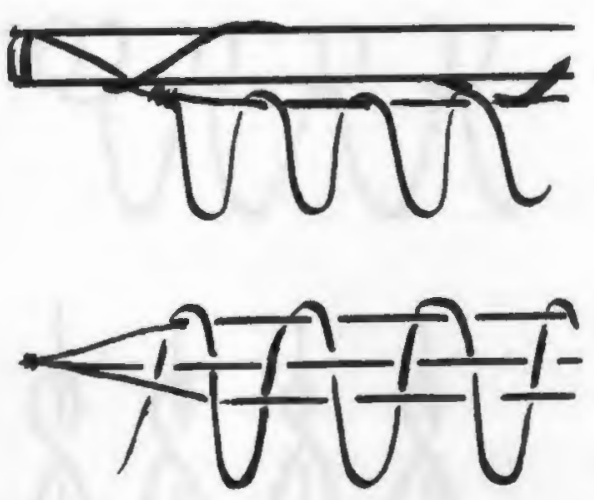

4. Alternate spiral

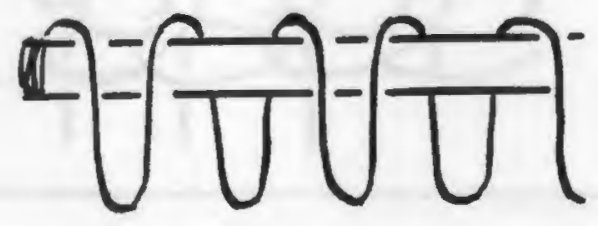

Continuous string, in open shed (Guatemala, Thailand) Indonesia

Oceania (Santa Cruz)

5. Spiral figure eight
Continuous string placed in open shed, loops are pulled up between warp yarns (Guatemala)

\section{Continuous string, in open} shed (Peru)
Continuous string, in open

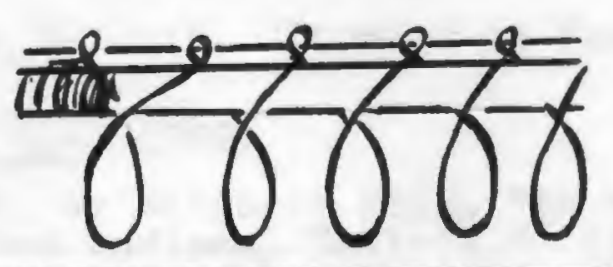
shed (Ecuador) 
6. Half hitch

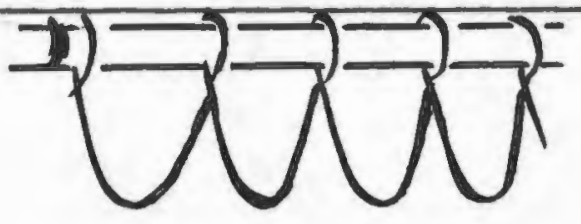

Continuous string, in open shed (Navajo, Apache)

7. Double half hitch

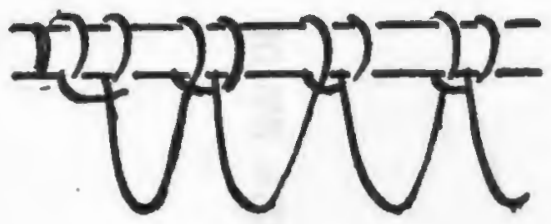

Continuous string, in open shed (Modern Peru)

8. Chain stitch replacing the rod

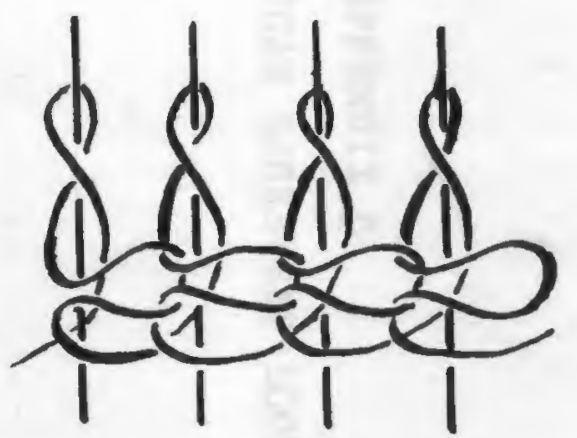

Continuous string, in open shed (Chaco, Chiriquano)

\section{Figure 5. -- Continued}

Source: Nos. 1, 2, 3, 4: H. L. Roth, "Studies in Primitive Looms" Man, Vol. 46, 1916 , p. 304 .

No. 4 - Also Joyce, Man, 1922.

No. 8 - after drawing by Margaret Hald, "An Unfinished Tubular Fabric from the Chiriquano Indians, Bolivia." (Stockholm: The Ethnological Museum of Sweden, 1962), Monograph Series Publication, No. 7. 
APPENDIX B

SOUTH AMERICAN BACKSTRAP LOOMS 


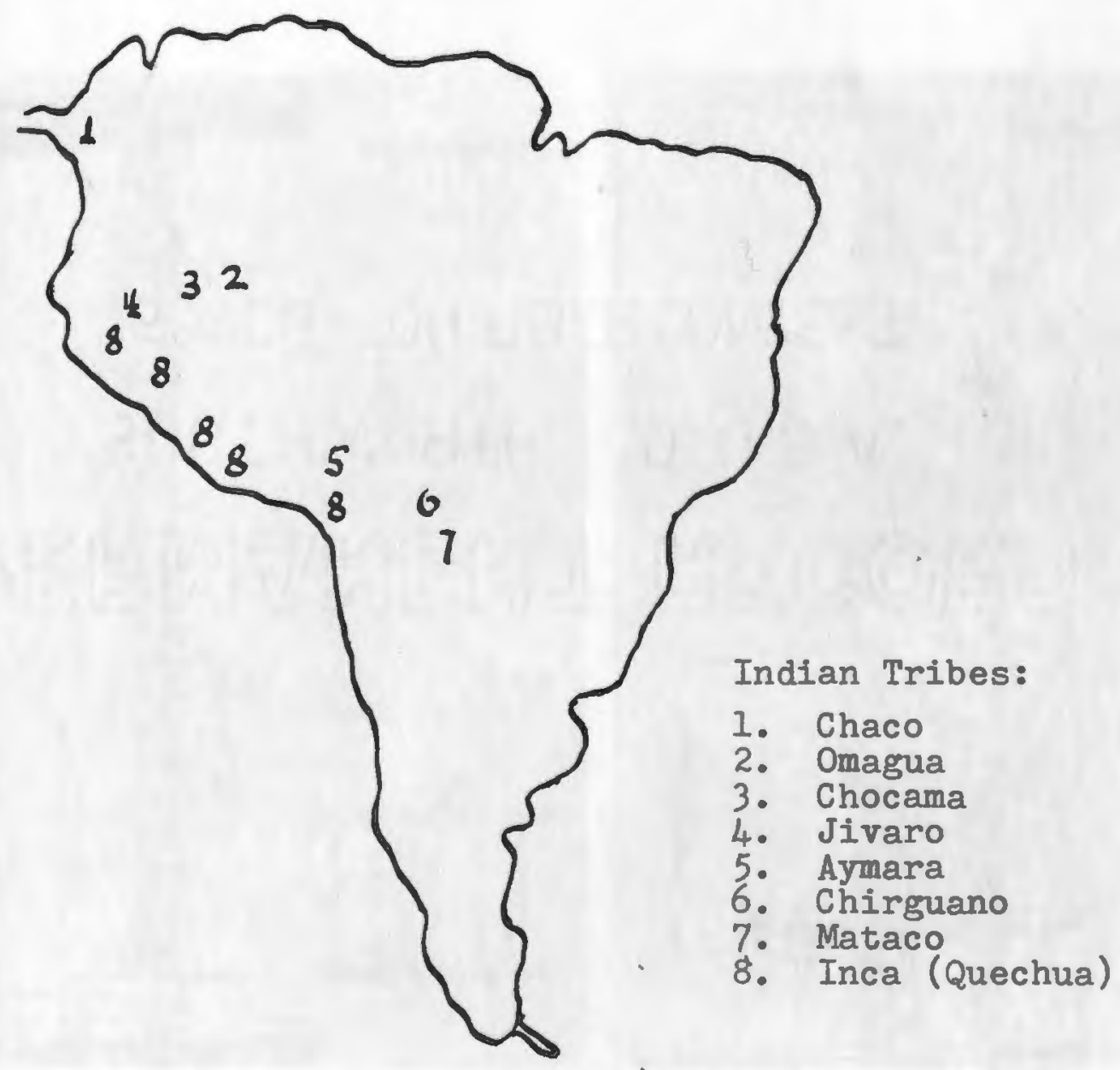

Figure 6. Current distribution of the backstrap loom in South America.

Source: Adapted from J. H. Steward, Native Peoples of South America (New York: McGraw Hill, 1959), p. 18. 


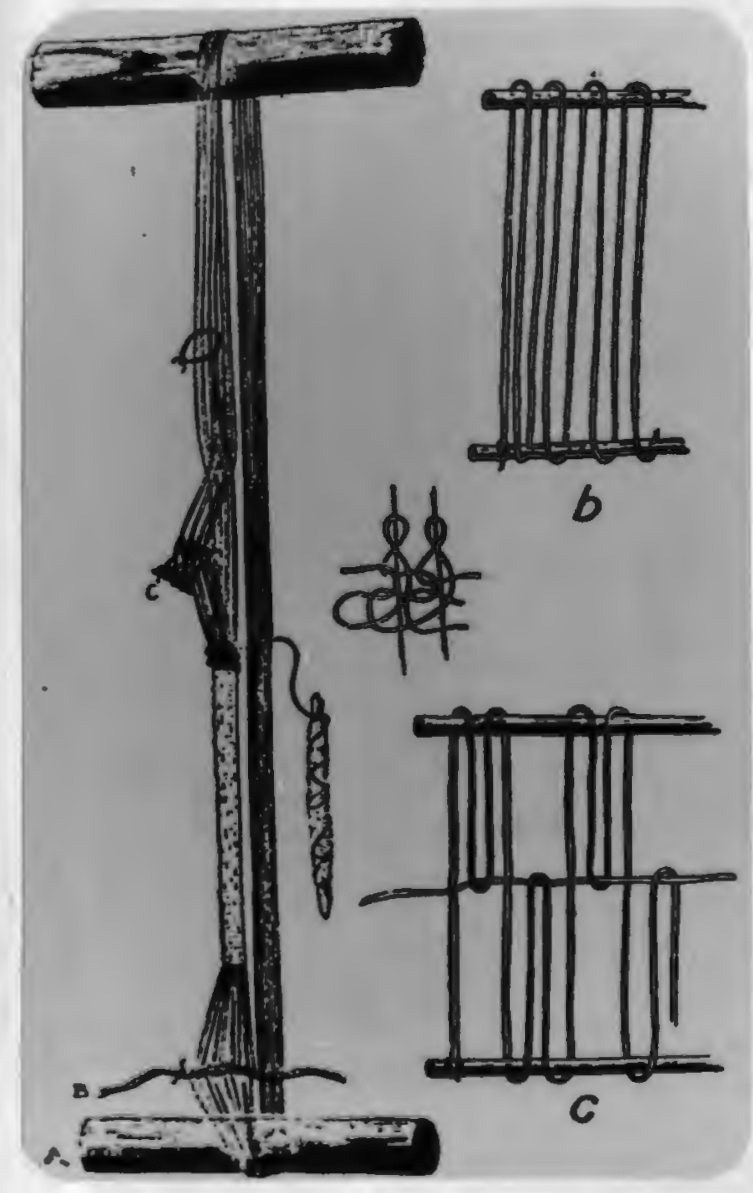

Band loom used by Chaco Indians

After Nordenskioeld, 1920, p. 110, Figure 55 .

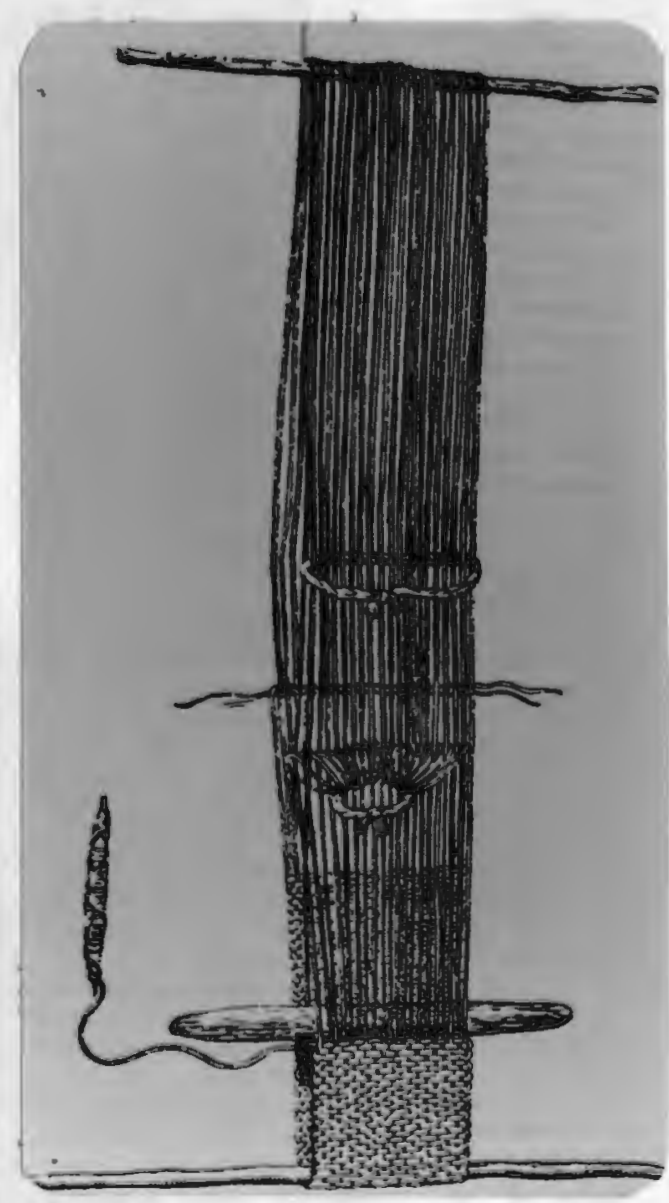

Mataco loom

After Nordenskioeld, 1919, p. 111, Figure 63.

Figure 7. Types of South American backstrap looms.

Source: J. H. Steward, ed. Handbook of the South American Indians (New York: Cooper Square Publishers, Inc., 1963), Vol. 5. 


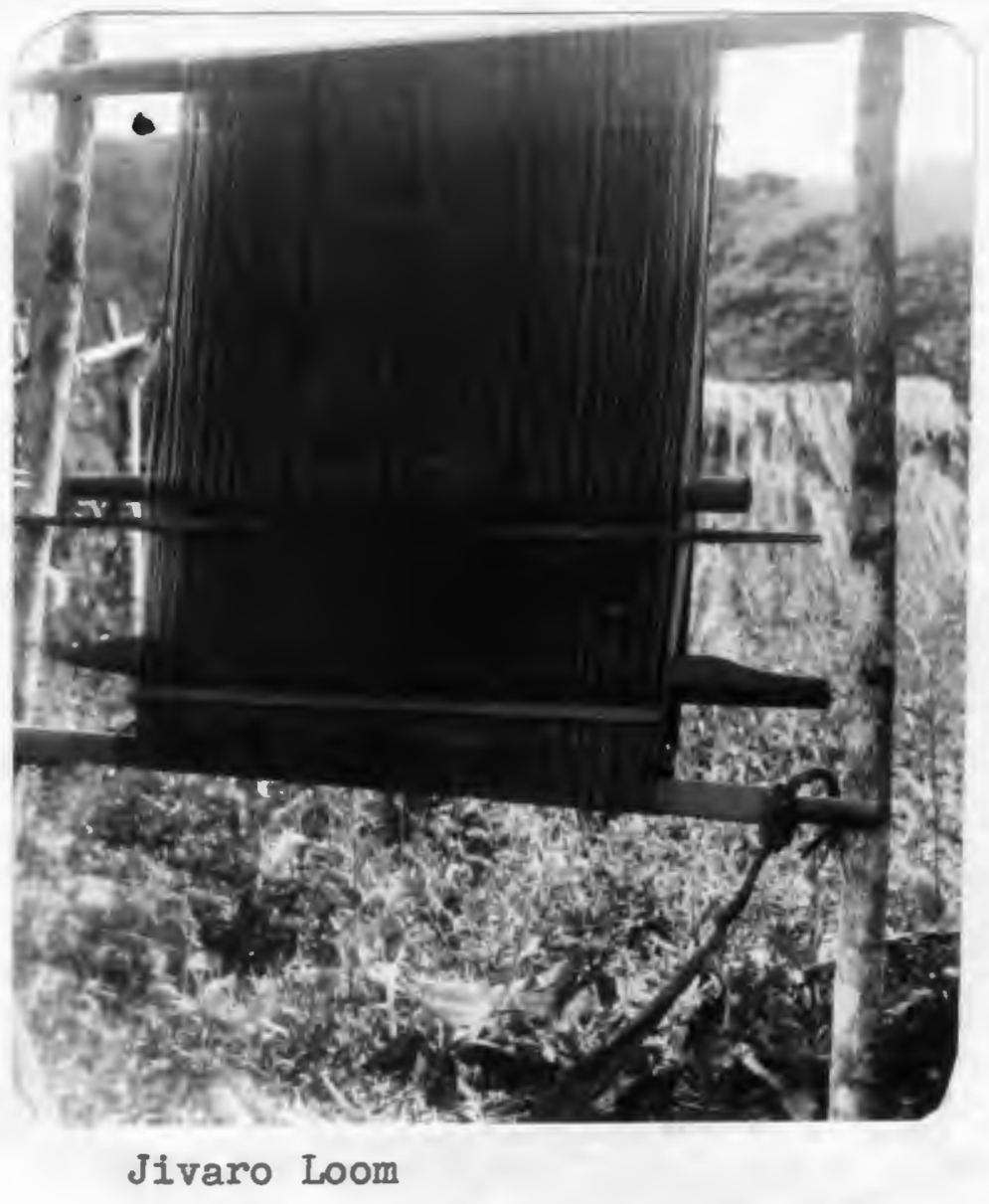

Source: Photograph Courtesy of Museum of the American Indian.

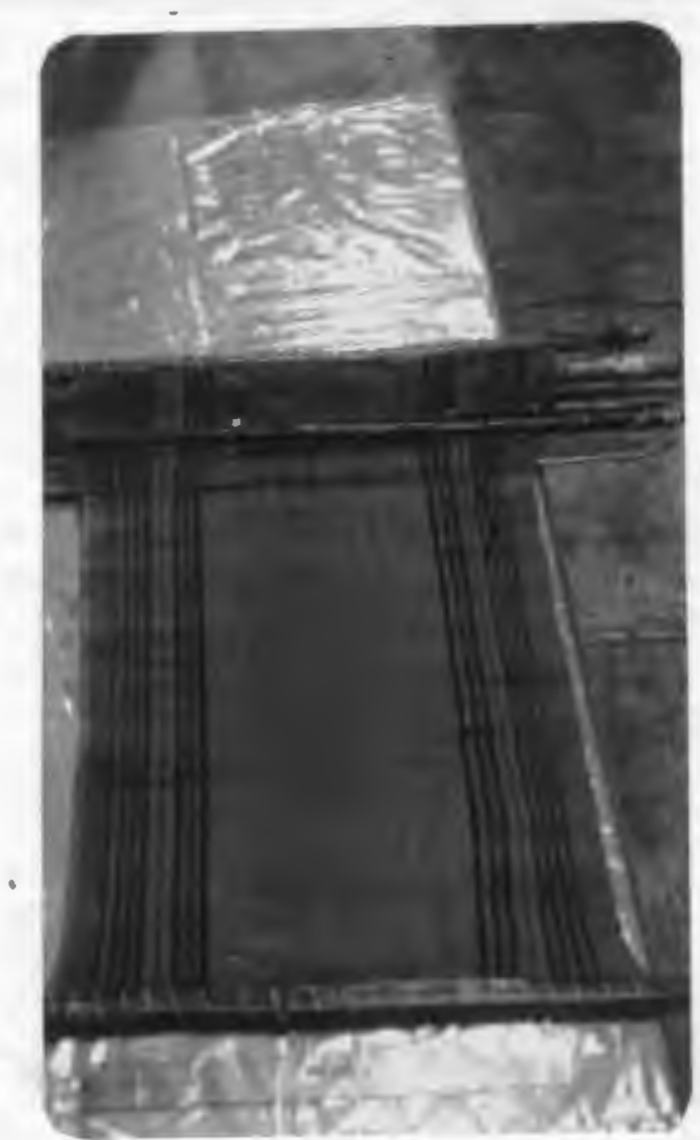

Quechua Loom

Source: Peabody Museum of Natural History, Yale University, \#5455. 


\section{APPENDIX C}

INFORMATION ON PERUVIAN TEXTILES 


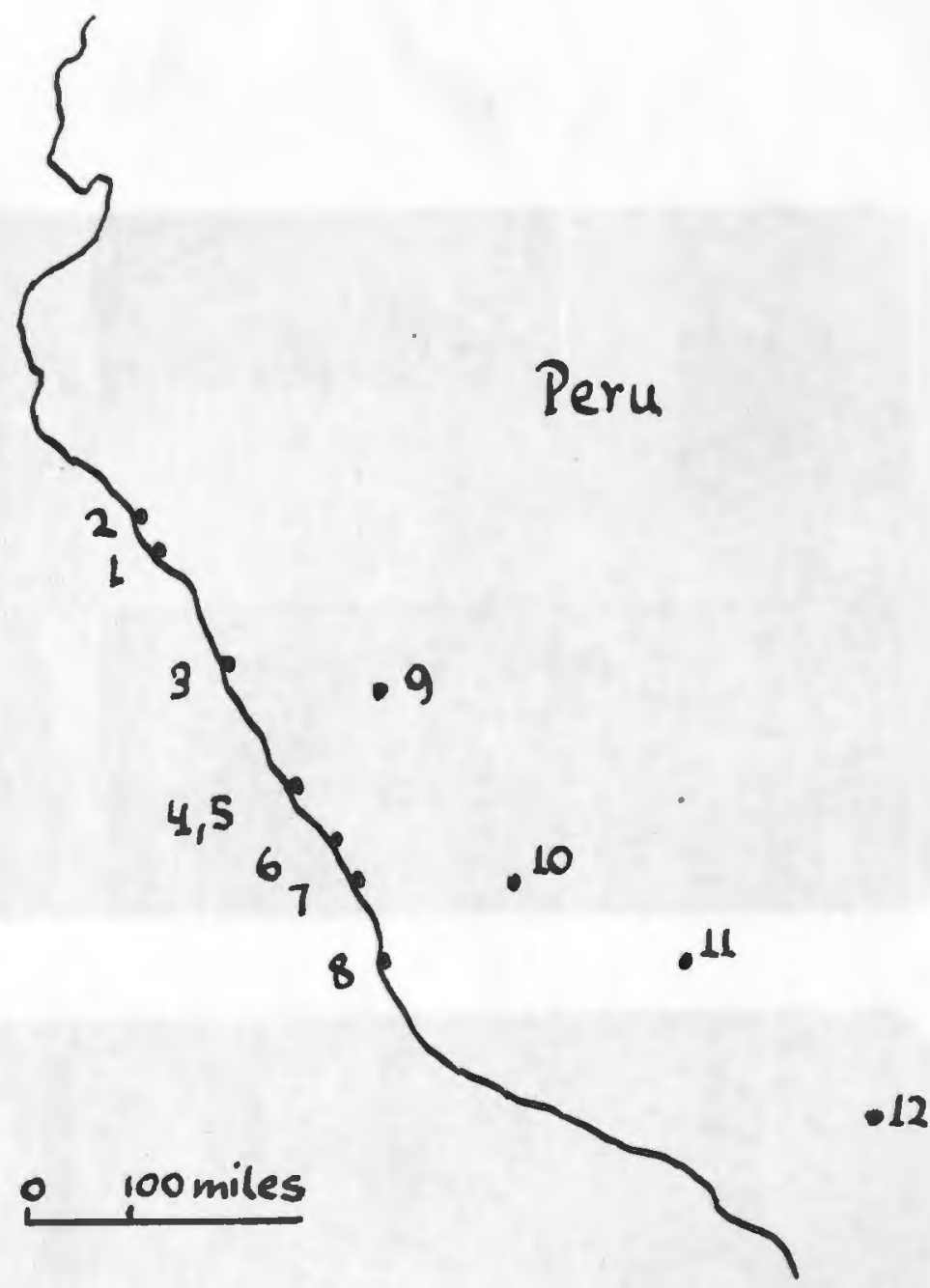

1. Chanchan

2. Huaca Prieta

3. Las Haldas

4. Chancay

5. Ancon

6. Pachacamac
7. Asia

8. Paracas

9. Chavin de Huantar

10. Huari

11. Cuzco

12. Tiahuanaco

Figure 9. Archaeological sites.

Source: Edward P. Lanning, Peru before the Incas (Englewood Cliffs, New Jersey: PrenticeHall, Inc., 1967), Maps, "Archaeological Sites." 

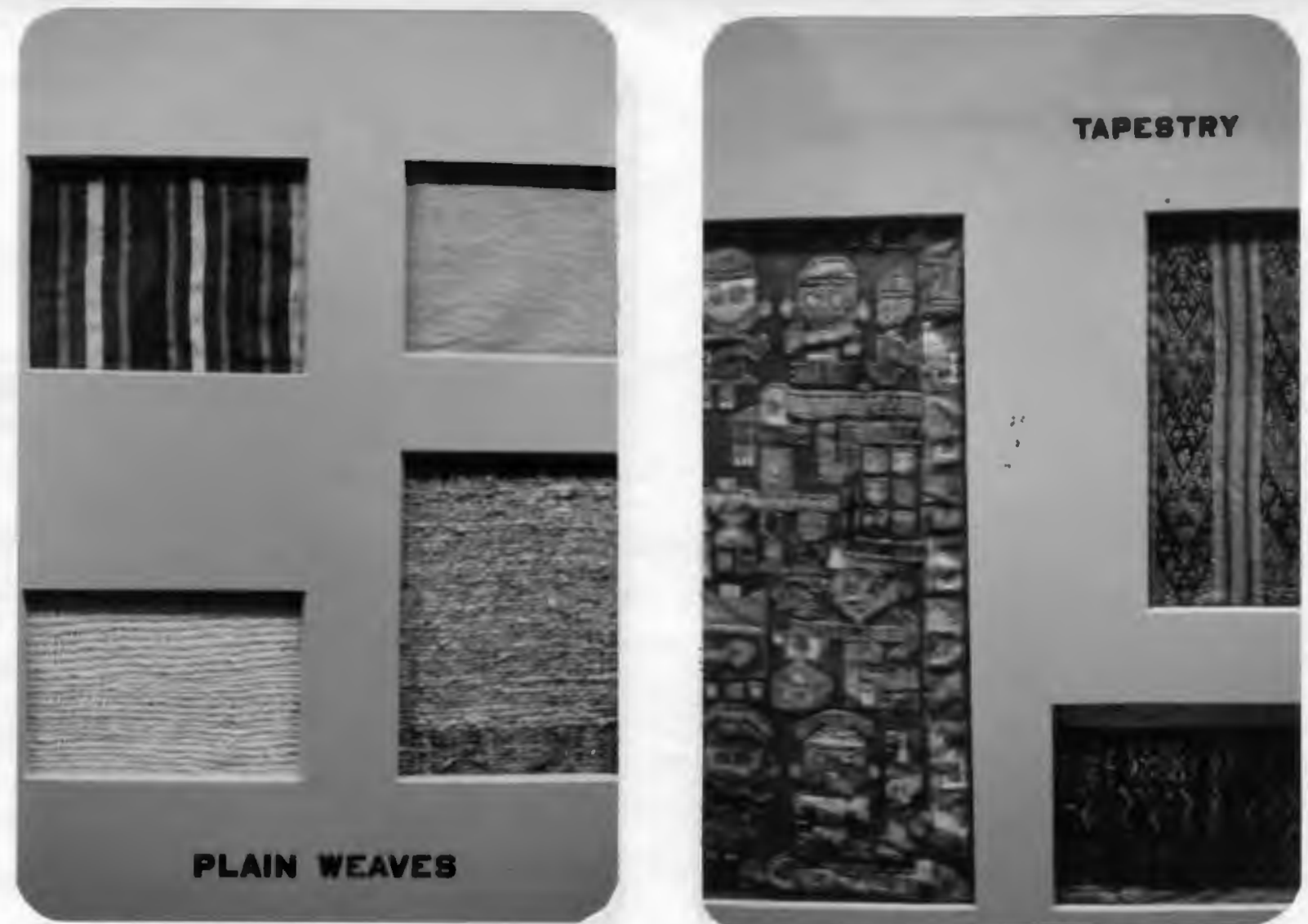

Figure 10. Peruvian woven textile techniques.

Source: National Museum of Natural History, Smithsonian Institute, Washington, D.C. 


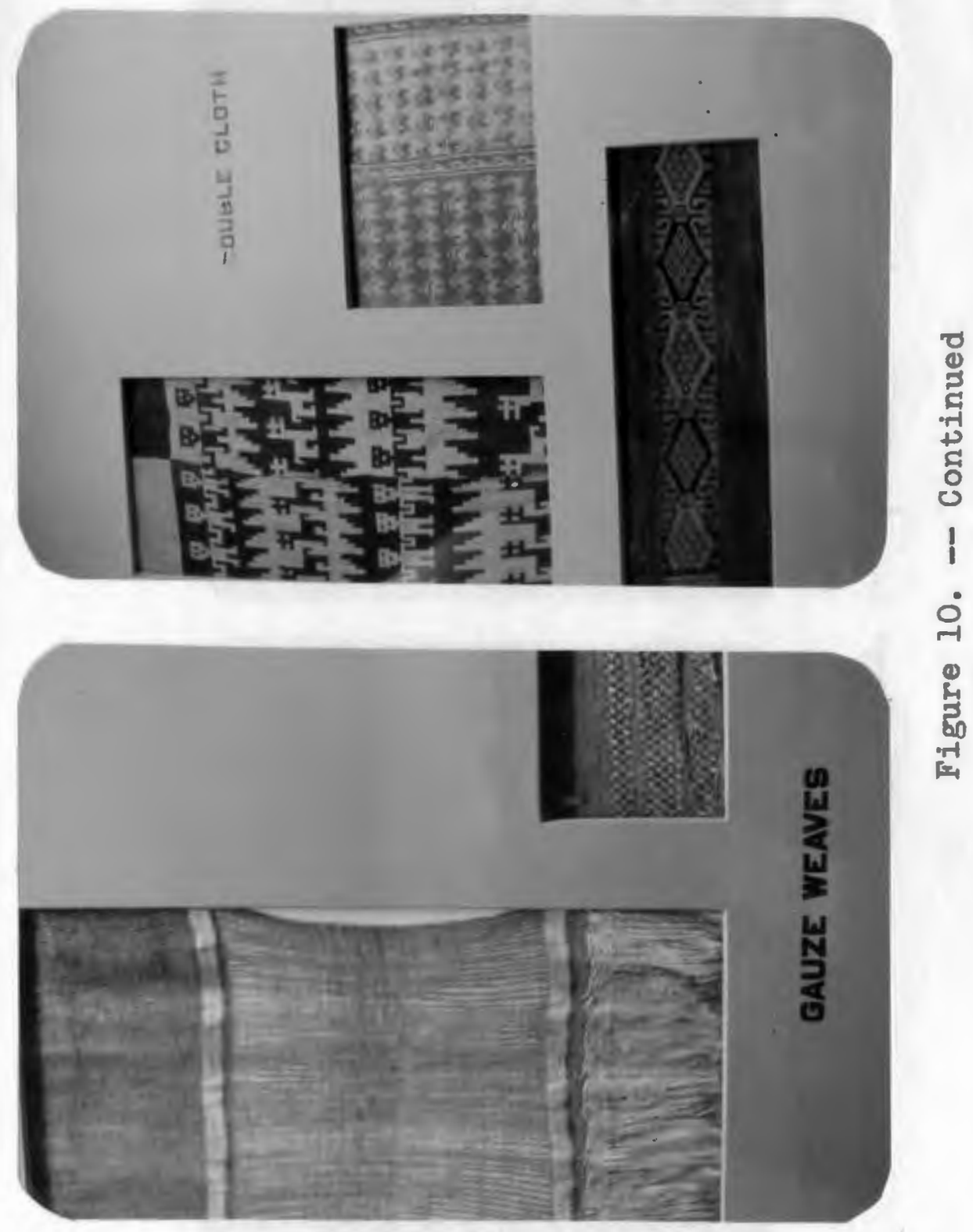




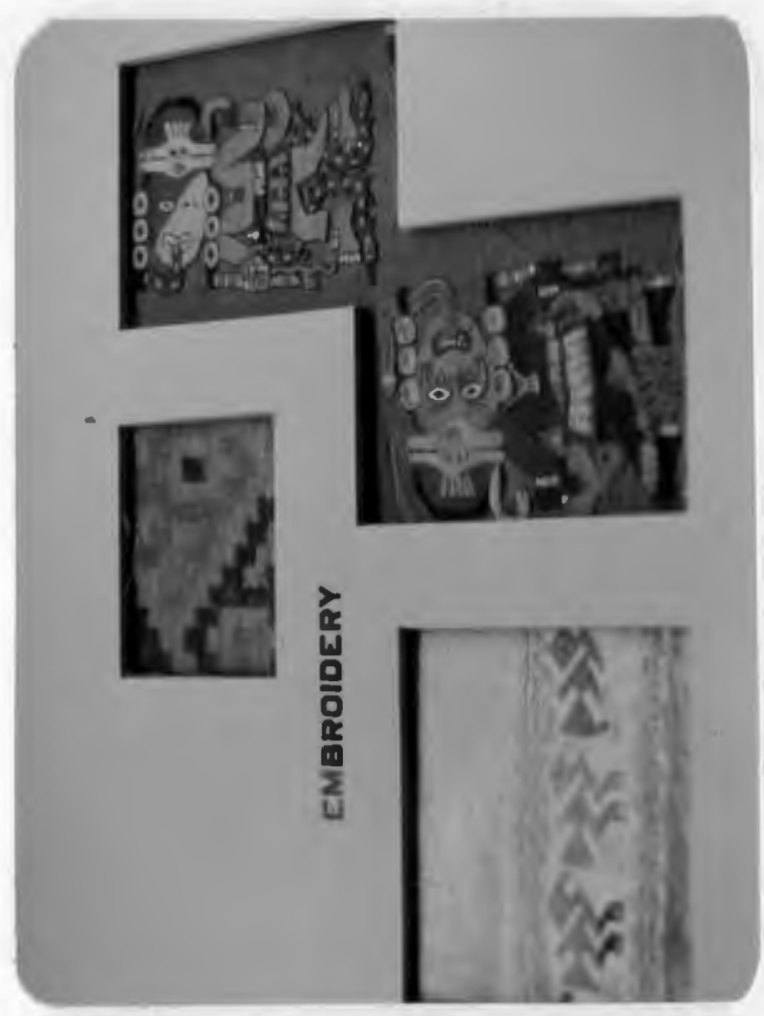

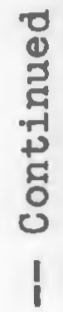

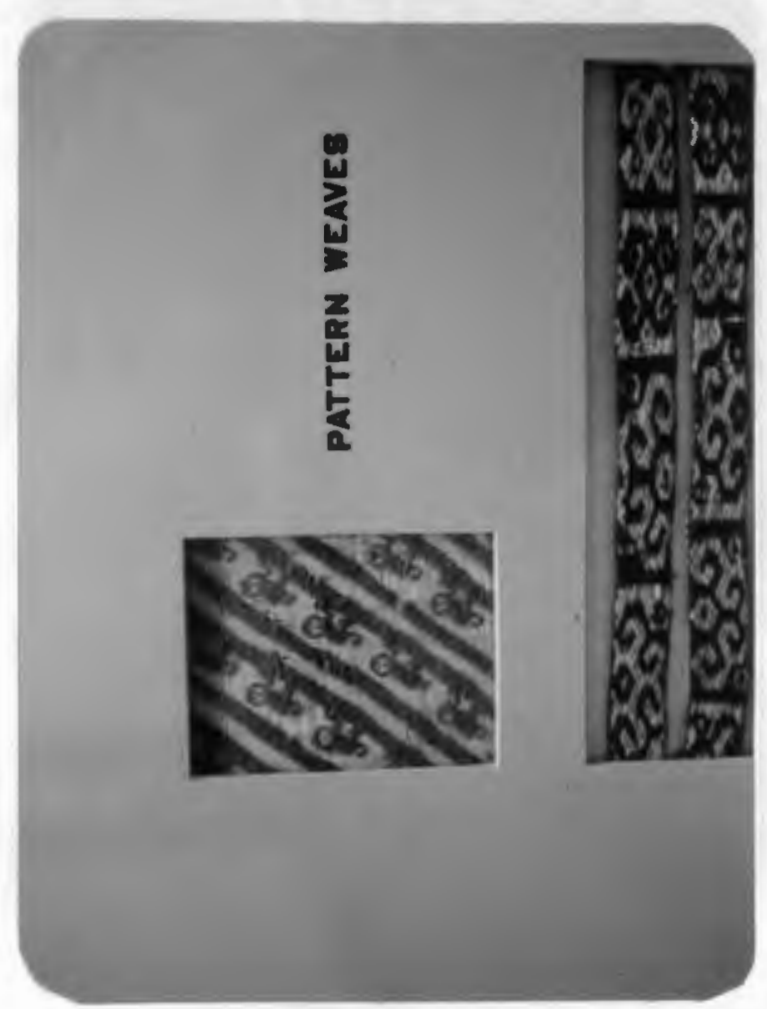

$\dot{9}$

先 


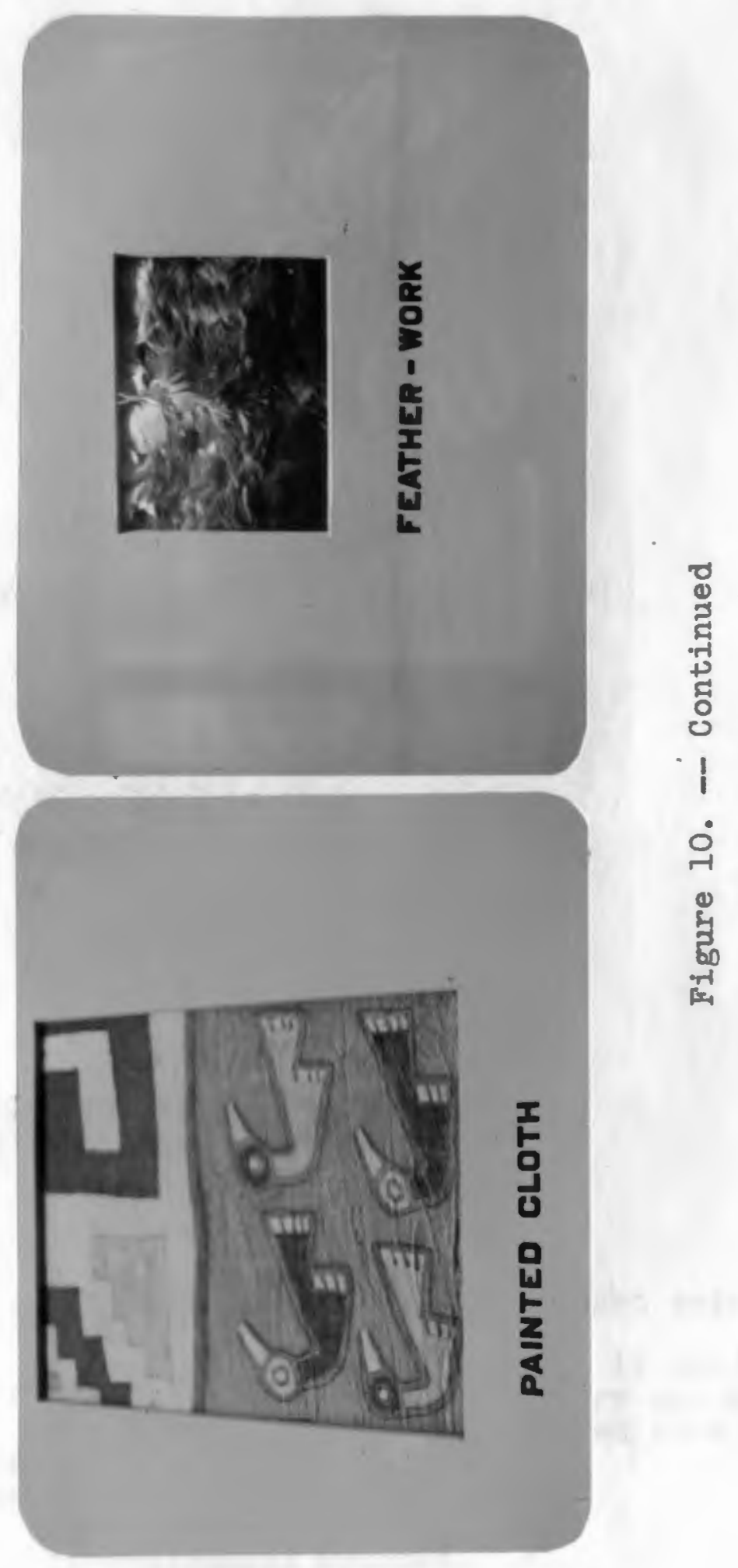




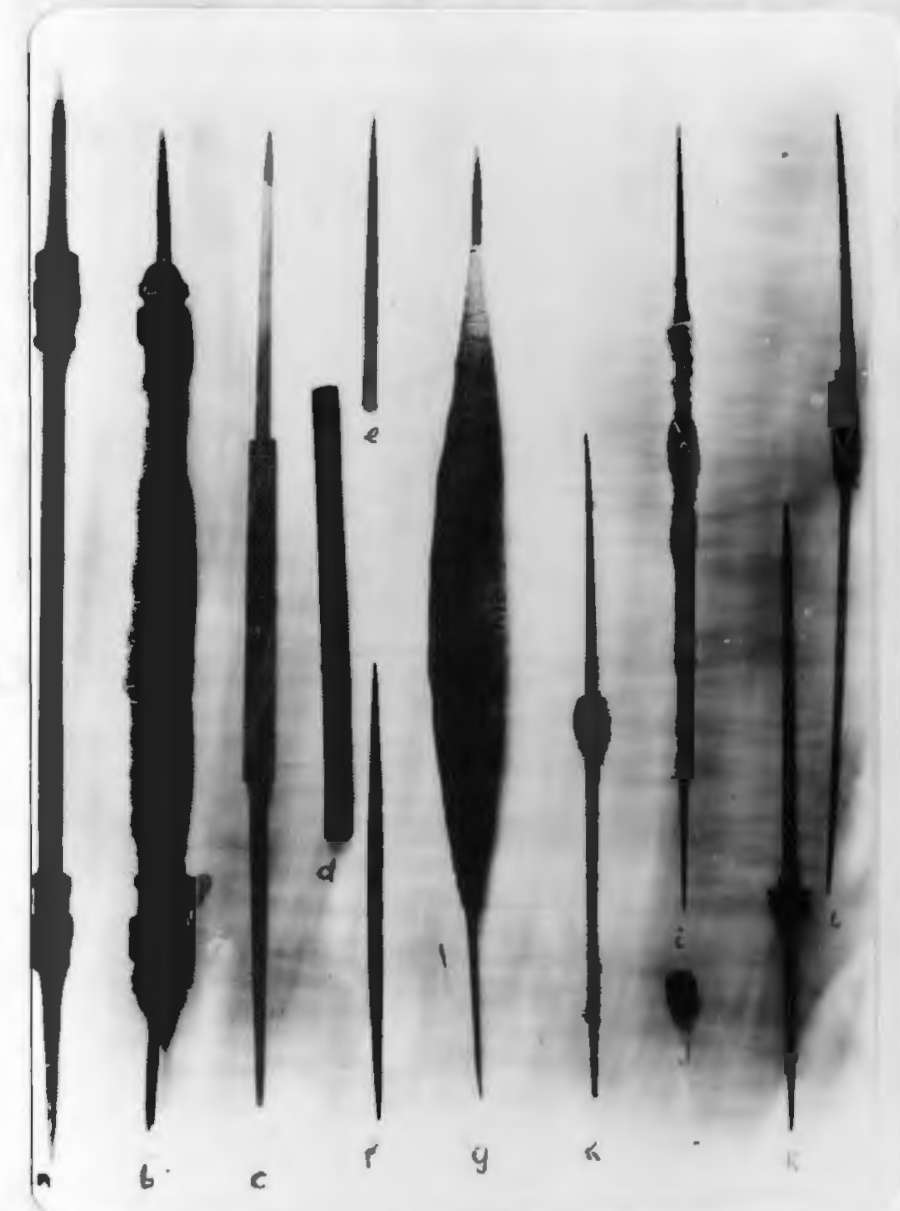

(a) Double spindle

(b) Double spindle with

(c) yarn

(c) Tri-part spindle empty

(d, e, f) Parts of tri-part spindle (g) Tri-part spindle with yarn

(h, i, k, l) Banded spindles

(j) Pottery and band removed from spindle

Figure 13. Archaeological spindle.

Source: American Museum of Natural History. Neg. 34633. 


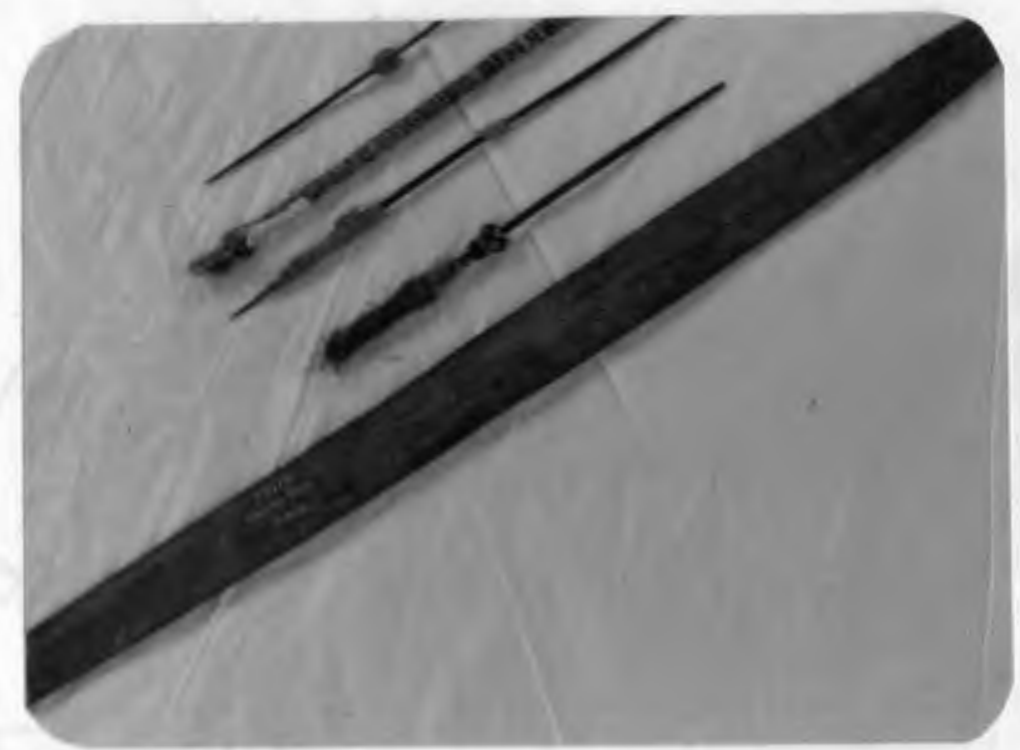

Figure 13. Spindles and weaving sword, Ancon. Source: National Museum of Natural History. \#74119.

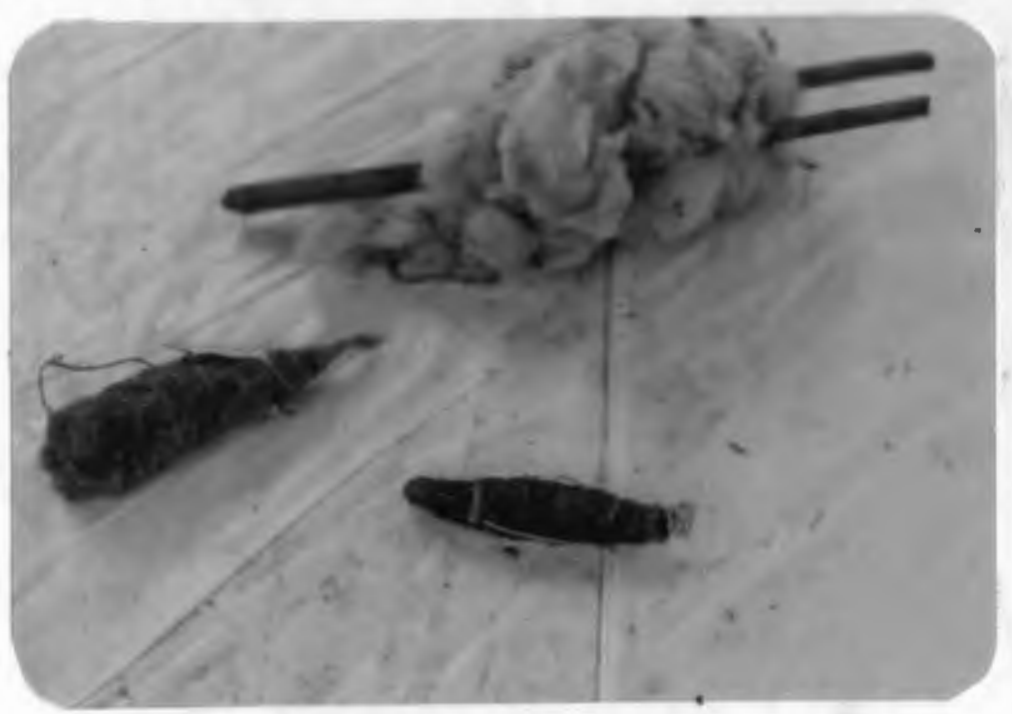

Figure 13. Implements.

Source: National Museum of Natural History. Wool distaff (\#30 7765) Cotton distaff (\#32 5016) Bobbin (\#65 383) 

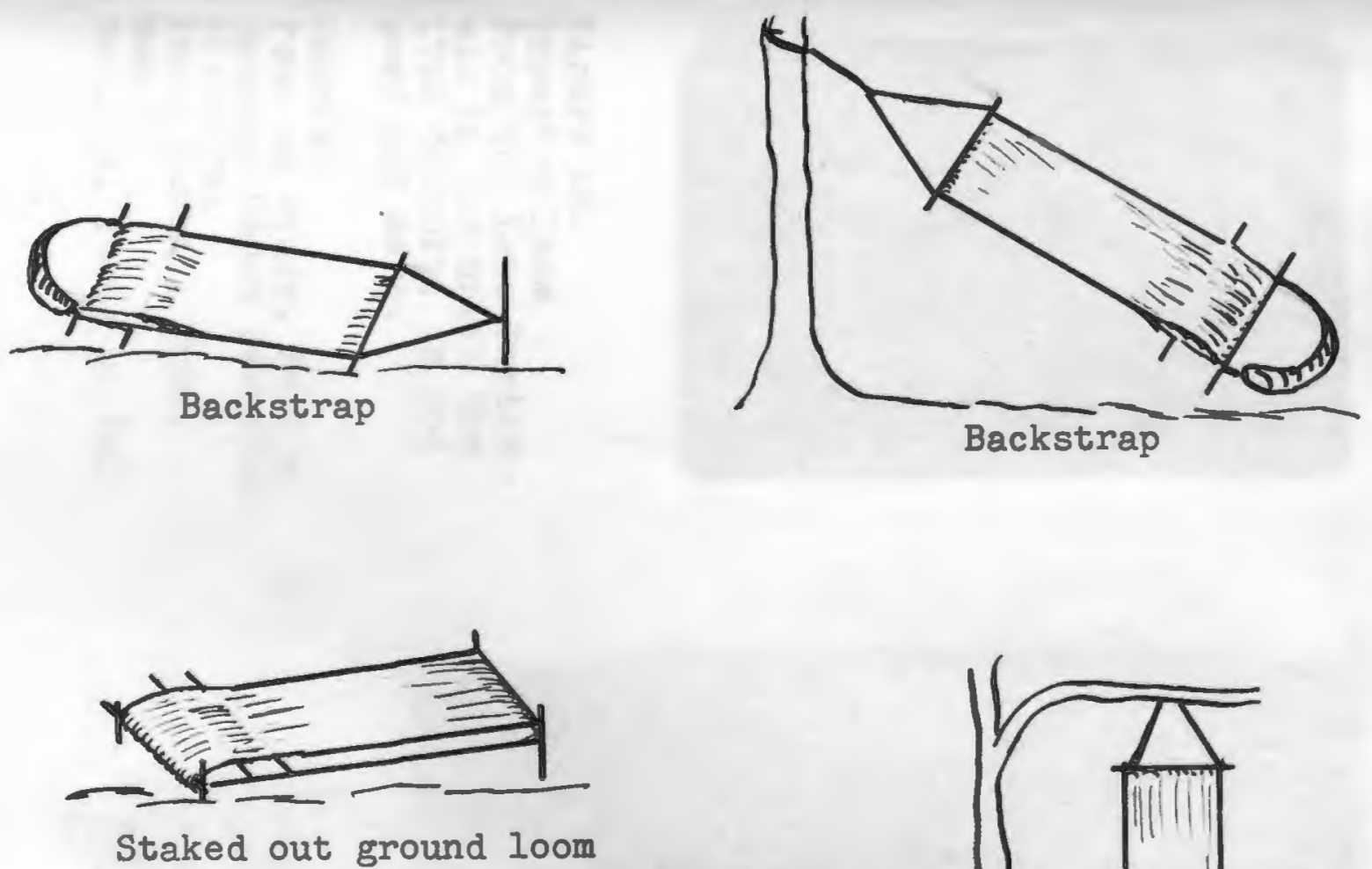

Source: "The Contemporary Quechua," in Handbook of South American Indian, ed. by Julian Steward, Plate 97

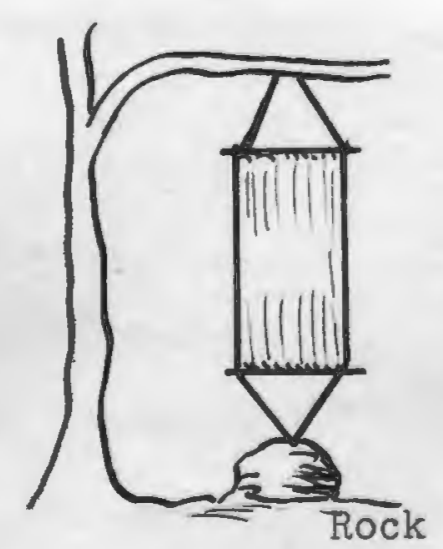

Source: After description on Catal.

Haffenreffer Museum, \#154

Figure 15. Native style looms of Peru Highlands. 

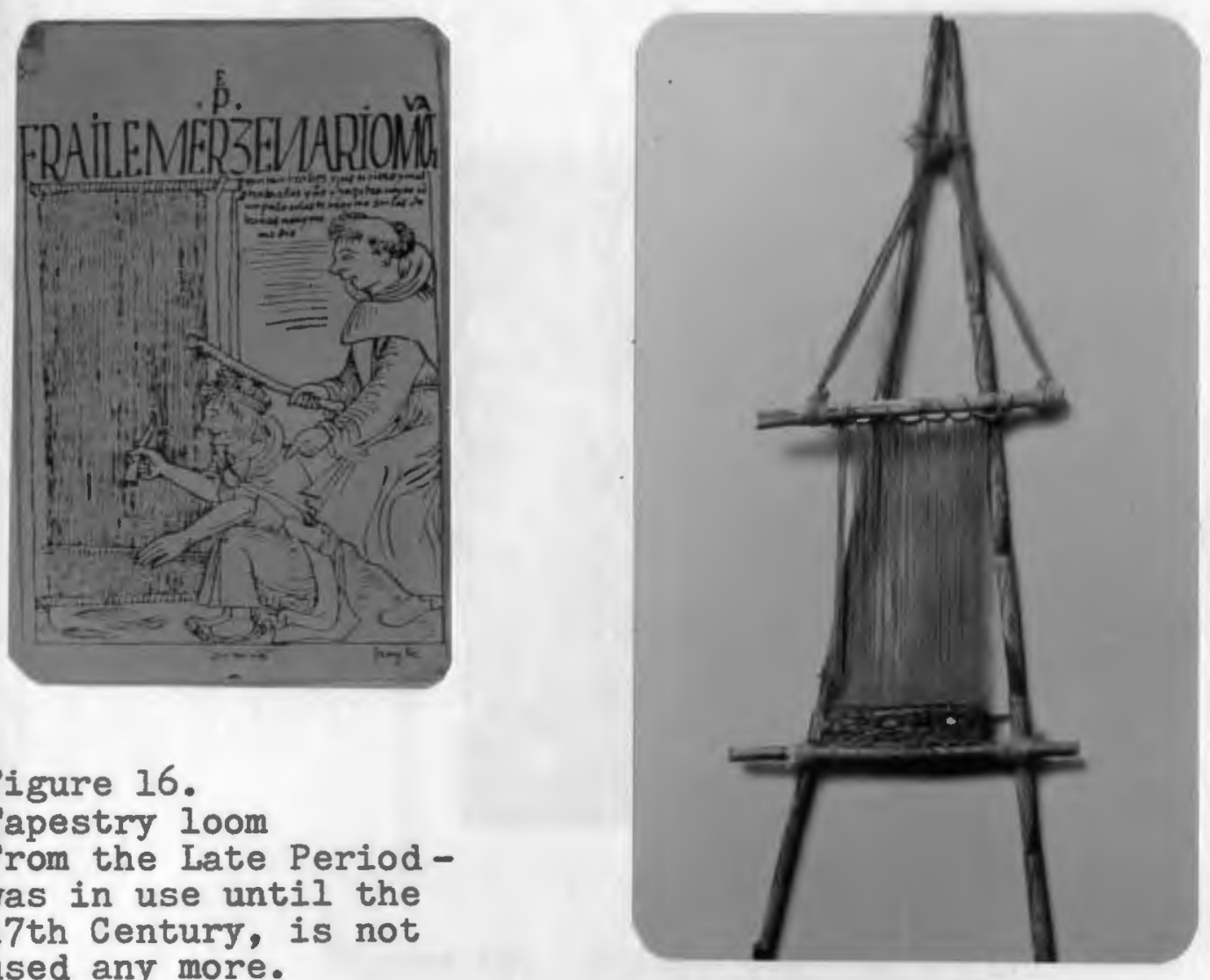

Figure 16.

Tapestry loom

From the Late Period was in use until the 17th Century, is not used any more.

Source:

Poma de Ayaly, Felipe

Guaman, Codex peruvien illustre.

Inst. Ethnol. Trav.

Mem.,

Vol. 23, 1936, p. 647.

Figure 17. A-frame loom

Source: Max Schmidt. Kunst and Kultur von Peru (Berlin, 1929) p. 78, Figure 520. 


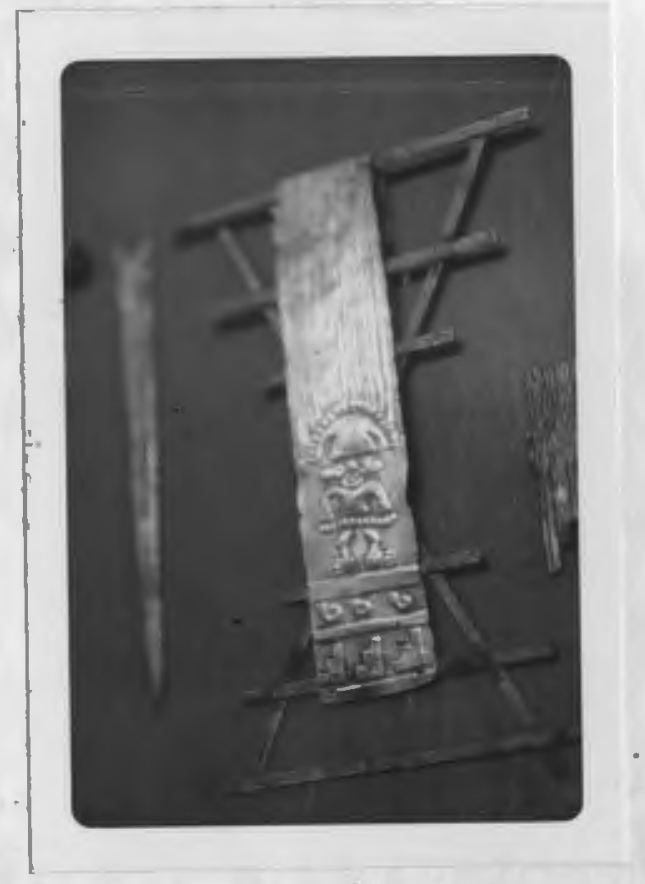

Figure 18. Silver toy for a girl representing a loom.

Source: Peabody Museum, Harvard University. \#PM 48-31-30/7161

Note: South Coast, Late Intermediate Period. 6 inches long 

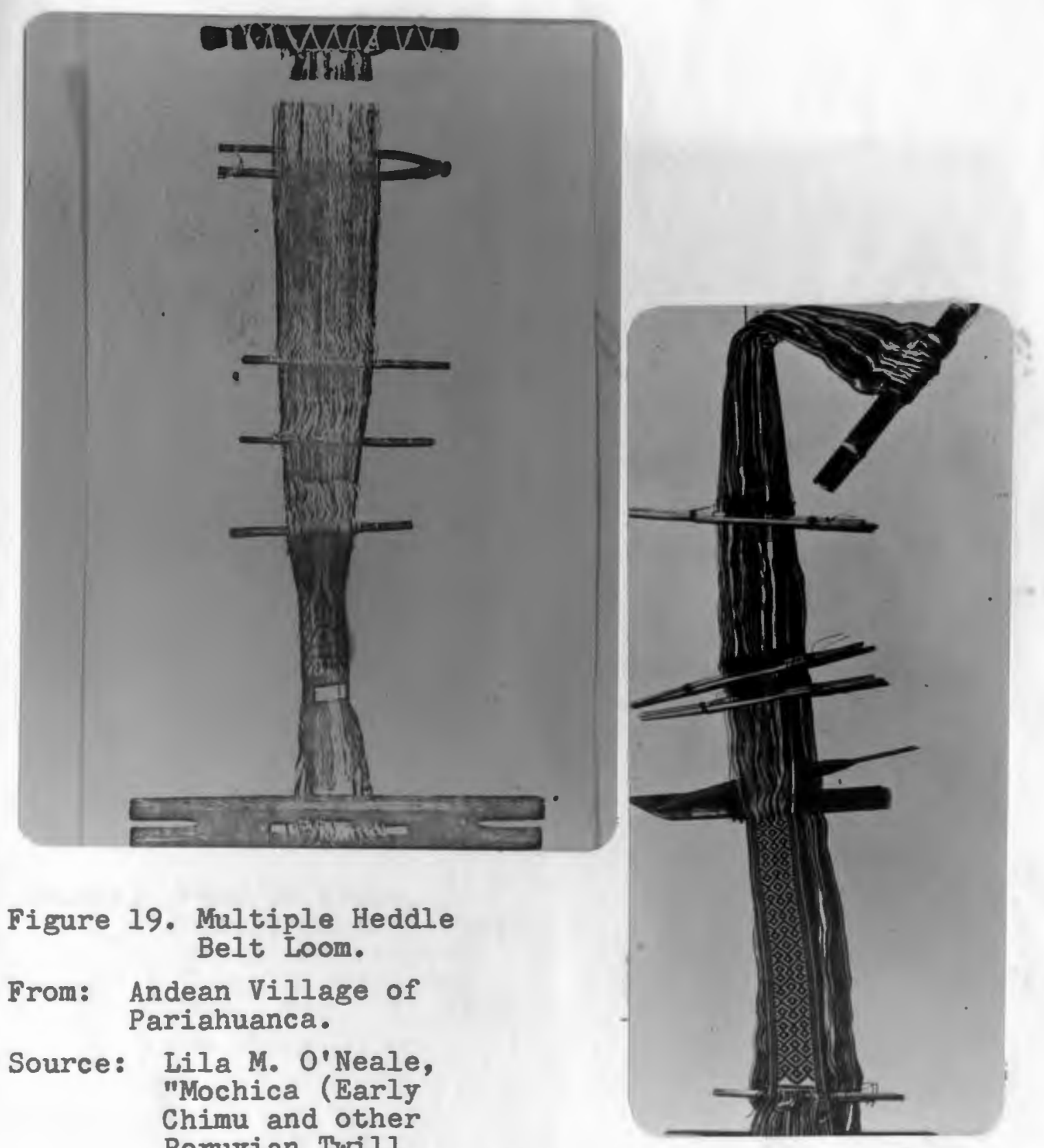

Figure 19. Multiple Heddle Belt Loom.

From: Andean Village of Pariahuanca.

Source: Lila M. O'Neale, "Mochica (Early Chimu and other Peruvian Twill Fabrics)," Plate 9.

Figure 20. Present day belt loom, warp-faced twill.

Source: Harriet Tidball, Peru: Textiles Unlimited, Part II, p. 30 . 

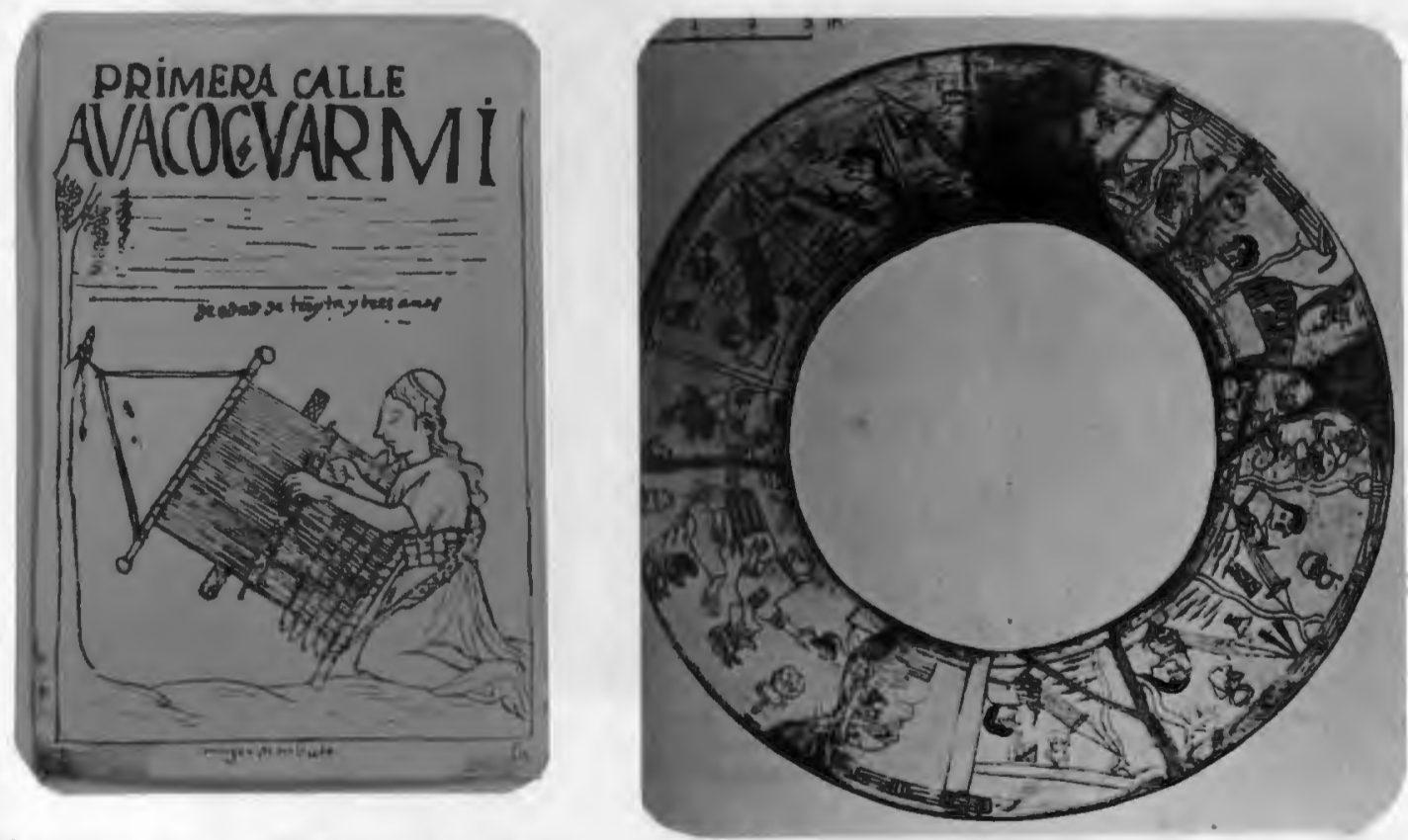

Figure 21. Inca weaving. Mochica type loom for weaving warpface cloth.

Figure 22. Weaving scenes from a pottery vessel of the

Source: Poma de Ayala, Felipe Guaman, Codex peruvien illustre. Inst. Ethnol. Trav. Mem. , Vol. 23, 1936, p. 115 . Mochica culture.

Source: Thomas A. Joyce, "The Peruvan Loom in the Proto-Chimu Period" (Man, Dec., 1921), pp. 177-180. 


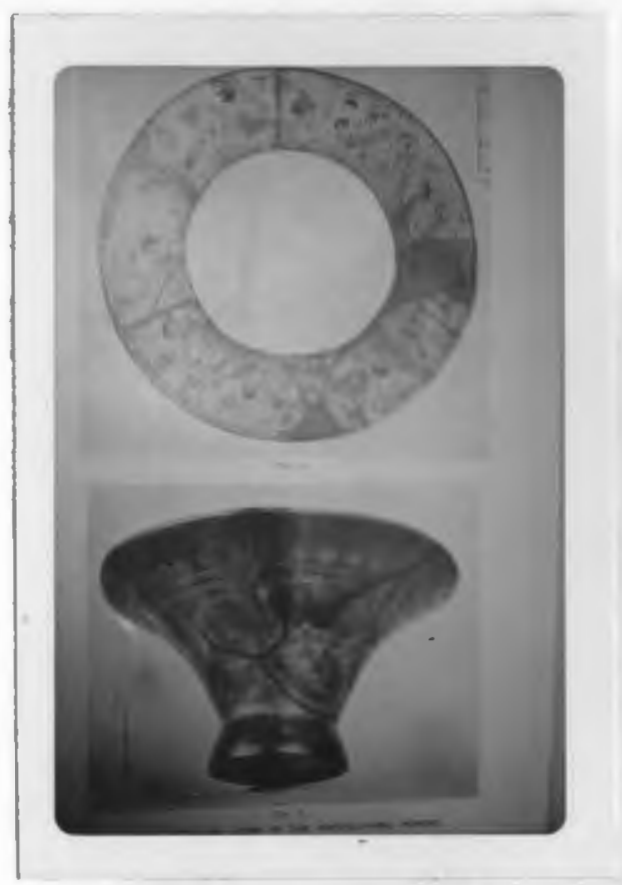

The Peruvian Loom from the earlier periods.

Source: Thomas A. Joyce, "The Peruvian Loom in the ProtoChimu Period," (Man, Vol. 2I), p. 177-180.

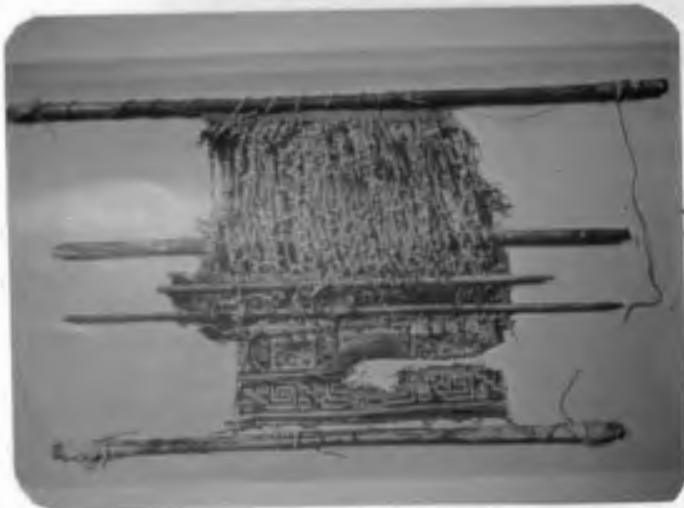

The Peruvian Loom from the late periods.

Source: Thomas A. Joyce, "Note on a Peruvian Loom in the Chimu Period," (Man, Vol. 22), pp. 1-2.

Figure 23. Peruvian looms from the earlier and late periods. 


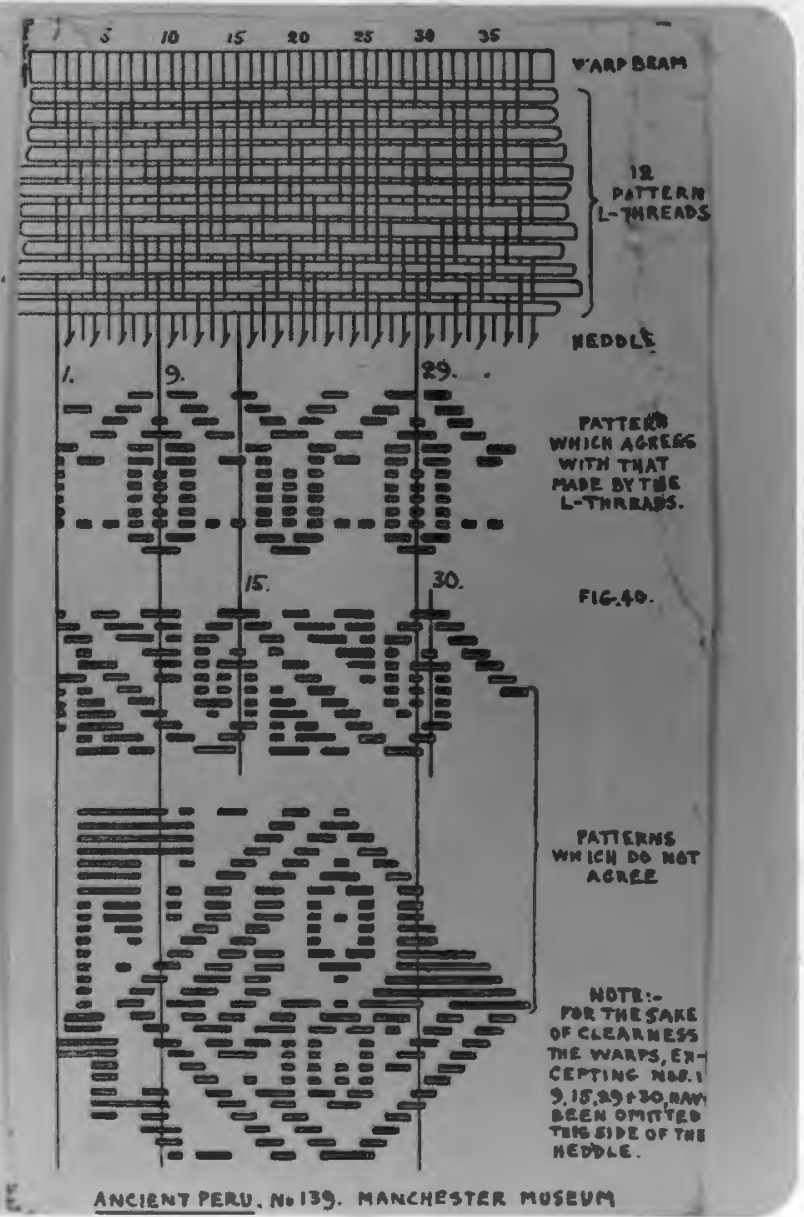

Figure 24. Peruvian loom with pattern sticks for pattern weaving.

Source: L. H. Roth, "Studies in Primitive Looms," Man, Vol. 46, 1916, p. 300. \#139, Manchester University Museum, called Dr. Smithies. 
APPENDIX D

INFORMATION RELATING TO QUESTIONNAIRE ON THE PERUVIAN BACKSTRAP

LOOM AND TEXTILES 
COVER LETTER FOR QUESTIONMAIRE

\author{
February 21, 1974
}

Dear Sirs:

I am a graduate student at the University of Rhode Island, Department of Textiles and Clothing, College of Home Economics and the subject of my master's thesis is "Potential and Limitations of the Peruvian Backstrap Loom."

I would appreciate your assistance in finding certain basic information. Would you kindly answer the attached questionnaire and return it to me at your earliest convenience by mailing it in the enclosed pre-addressed envelope.

Thank you very truly,

Rosa J. Abboud

6 Heritage Drive

North Dartmouth, Mass.

02747 
DATE:

NAME :

MUSEUM:

PART A:

Do you have any Peruvian backstrap looms?

If yes, please refer to your own collection and place a check

mark $(V$ ) in the corresponding columns.

\section{Length of loom bars:

$$
36^{\prime \prime}
$$

Shape of loom bar:

round

flat

No. of string heddle rods

in addition to shed roll or

No. of string heddle cords left

in warp:

one

two

three

more than three (indicate number)

No. of shed rolls:

one

two

more (indicate number) - -

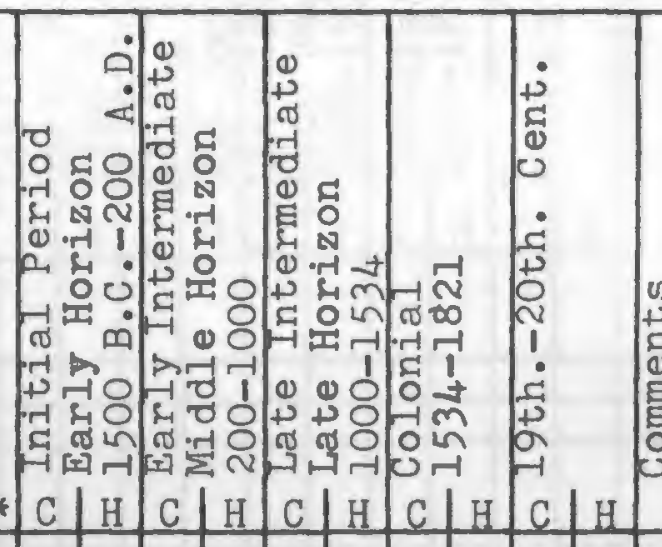

*C Coast; H Highlands 
Shape of shed rolls: round

flat

forked stick

Type of string heddle (on rod or cord): spiral

double half hitches

others (indicate method of looping)

Presence of template or

tenter to maintain even

weaving width:

Shape of template:

(describe)

Types of fabrics still on the loom

(if pattern sticks were found on

the loom, please add the letter $\underline{P}$ )

On looms without heddle rods: tapestry

plain weave (without patterning)

weft brocading

warp patterning

gauze

twill

double cloth

triple cloth

*C Coast; $\mathrm{H}$ Highlands 


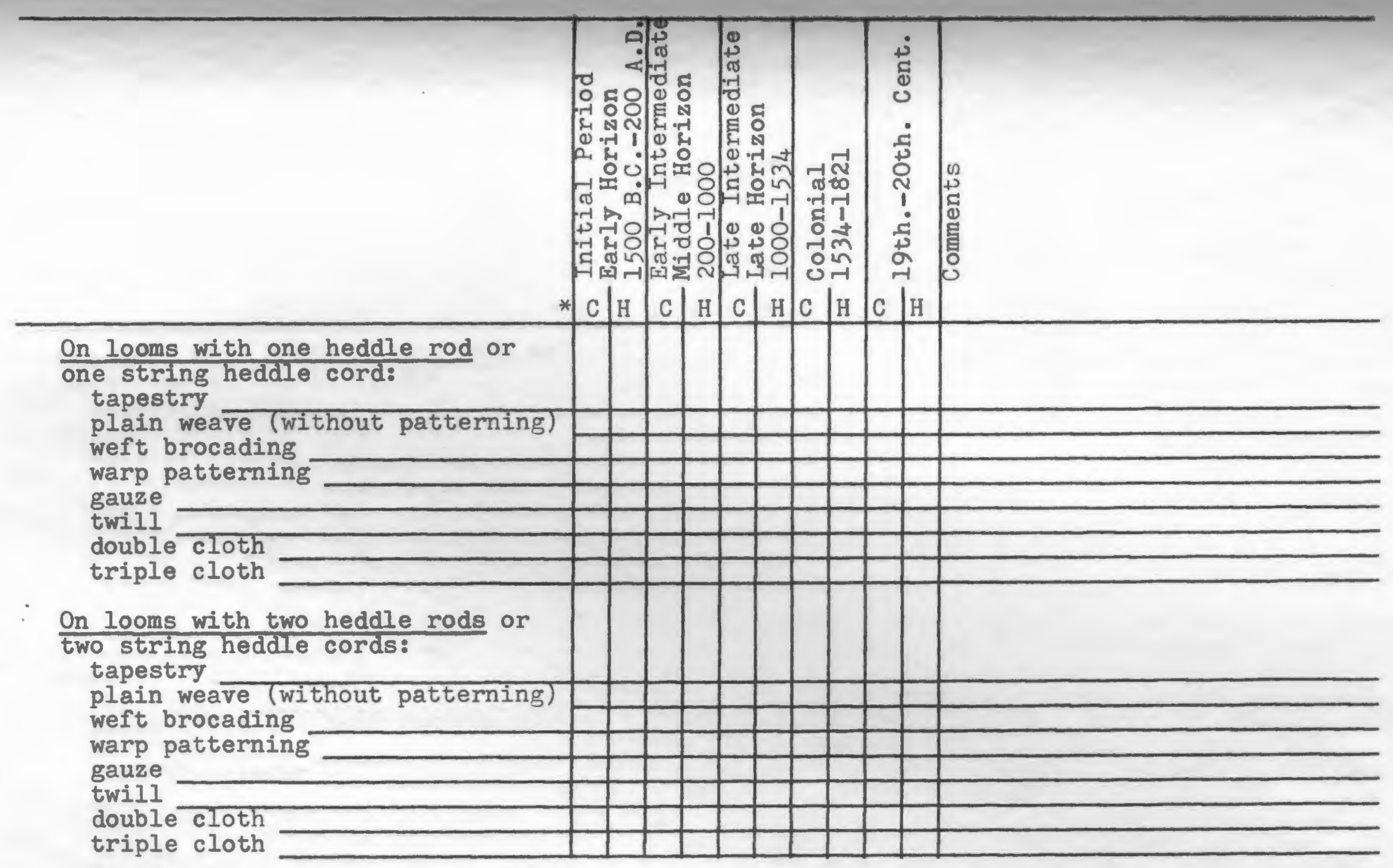

*C Coast; H Highlands 


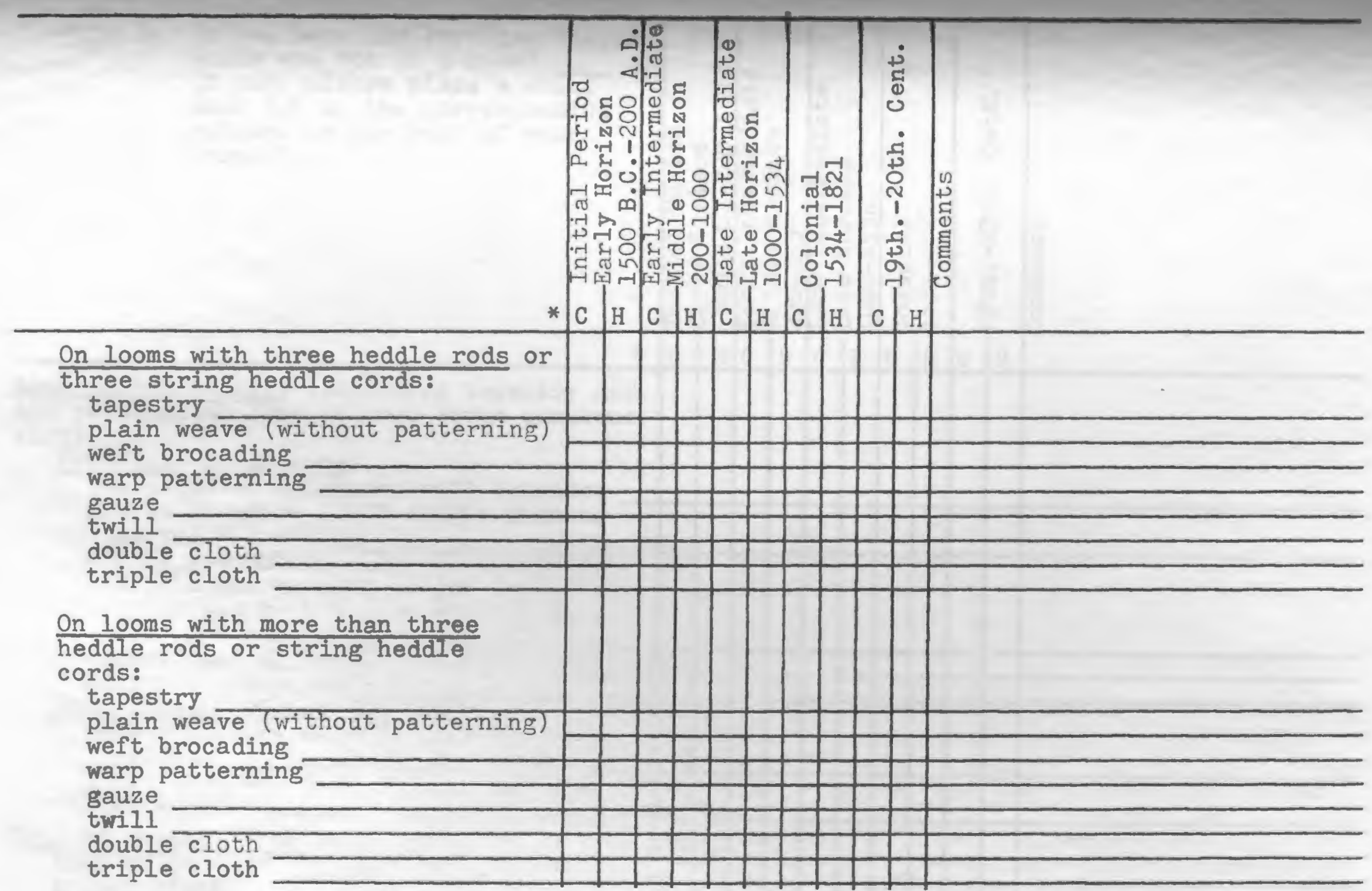

*C Coast; H Highlands 
PART B: Do you have any Peruvian fabrics which are not on a loom? If yes, please place a check mark ( $\backslash$ ) in the corresponding columns to the best of your knowledge.

*

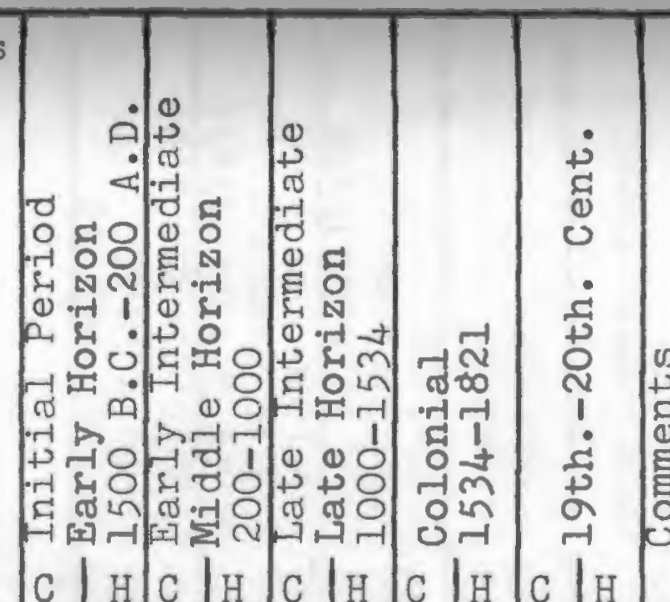

Loom-shaped fabrics (excluding tapestry and the rectangular four selvage woven constmuction):

Technique of shaping:

increased or decreased weft tension: change in weave (from single warp to paired warps):

adding and subtracting of warp yarns within the weaving length (not connected to the loom strings at the loom bars): subtracting of warp yarns only: adding of warp yarns only:

Technique of adding warp yarns: warp yarns are interlocked with warp yarns:

warp yarns are interlocked with a weft yarn:

Type of shaped garments or textiles:

bage or pouches

breech cloth

shirt

other (indicate the use if possible) -- 


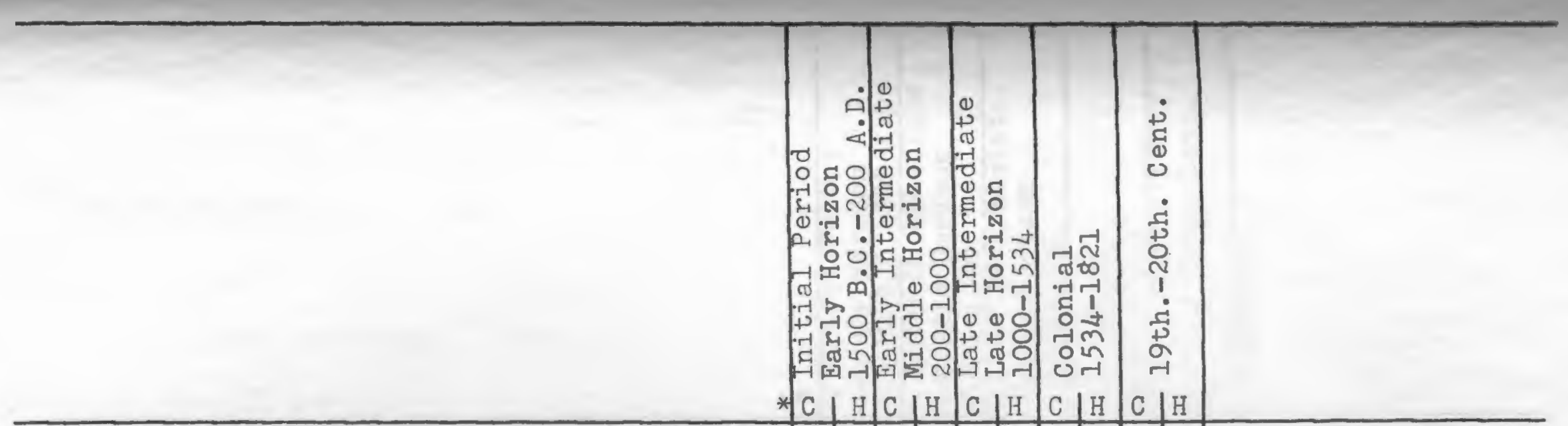

Double cloth:

double faced (both fabric sides are completely woven as double cloth, even in those areas where there is no patterning from selvage to selvage):

range of fabric width of fabric having two selvages (in inches):

single faced (floating warp yarns appear on the lower fabric side in those areas where there is no patterning from selvage to selvage):

range of fabric width of fabrics having two selvages (in inches):

Triple cloth:

double faced (both fabric sides are completely woven)

single faced (floating warp yarns appear on the lower fabric side)

range of width (in inches)

(if the fabric is a fragment, please add

the letter $\underline{F}$ )

*Coast C; Highlands $H$ 


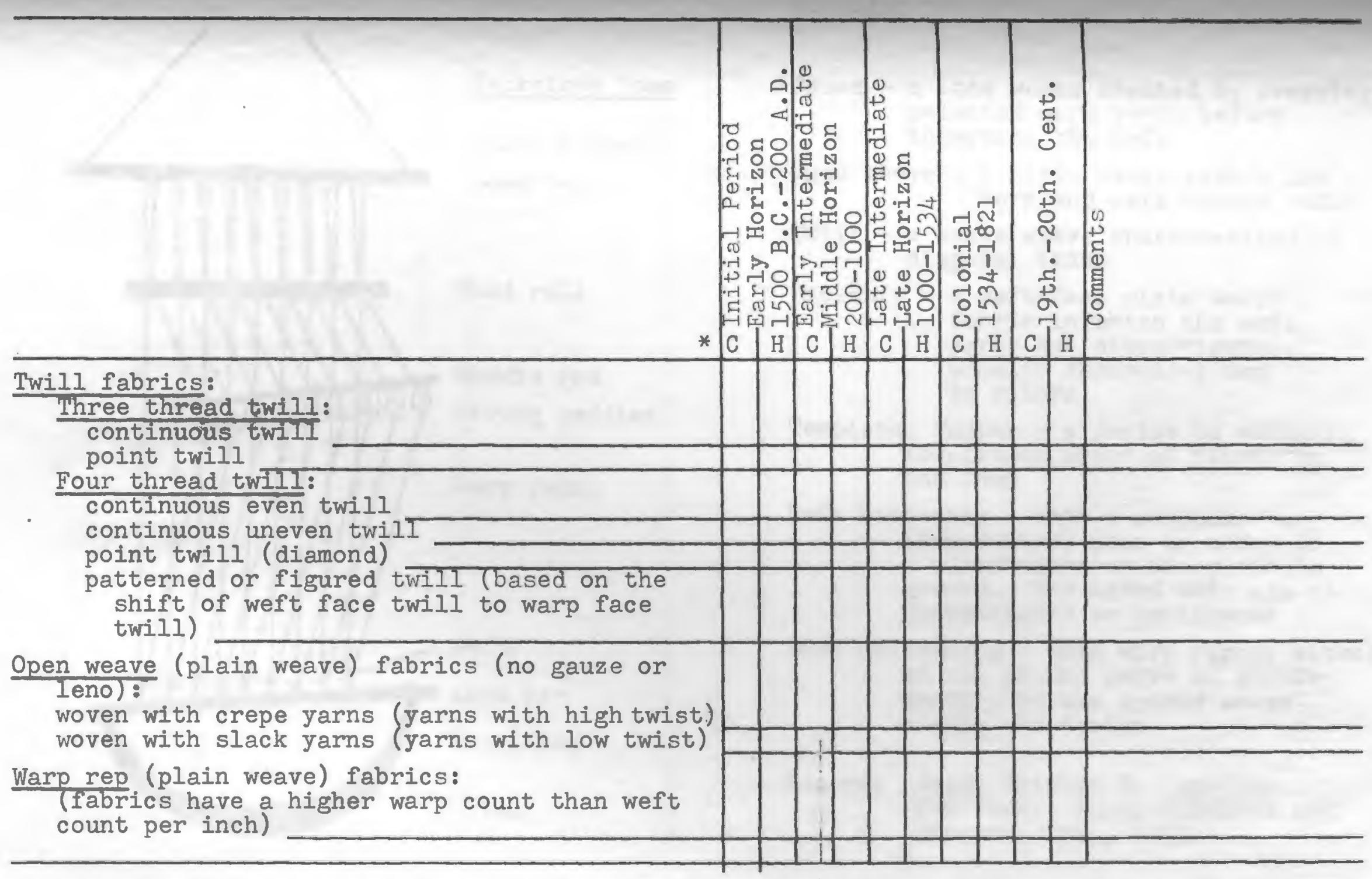

Additional comments: (Please indicate if photo copies and if additional written information on the specimens are available)

*C Coast; $\mathrm{H}$ Highlands 


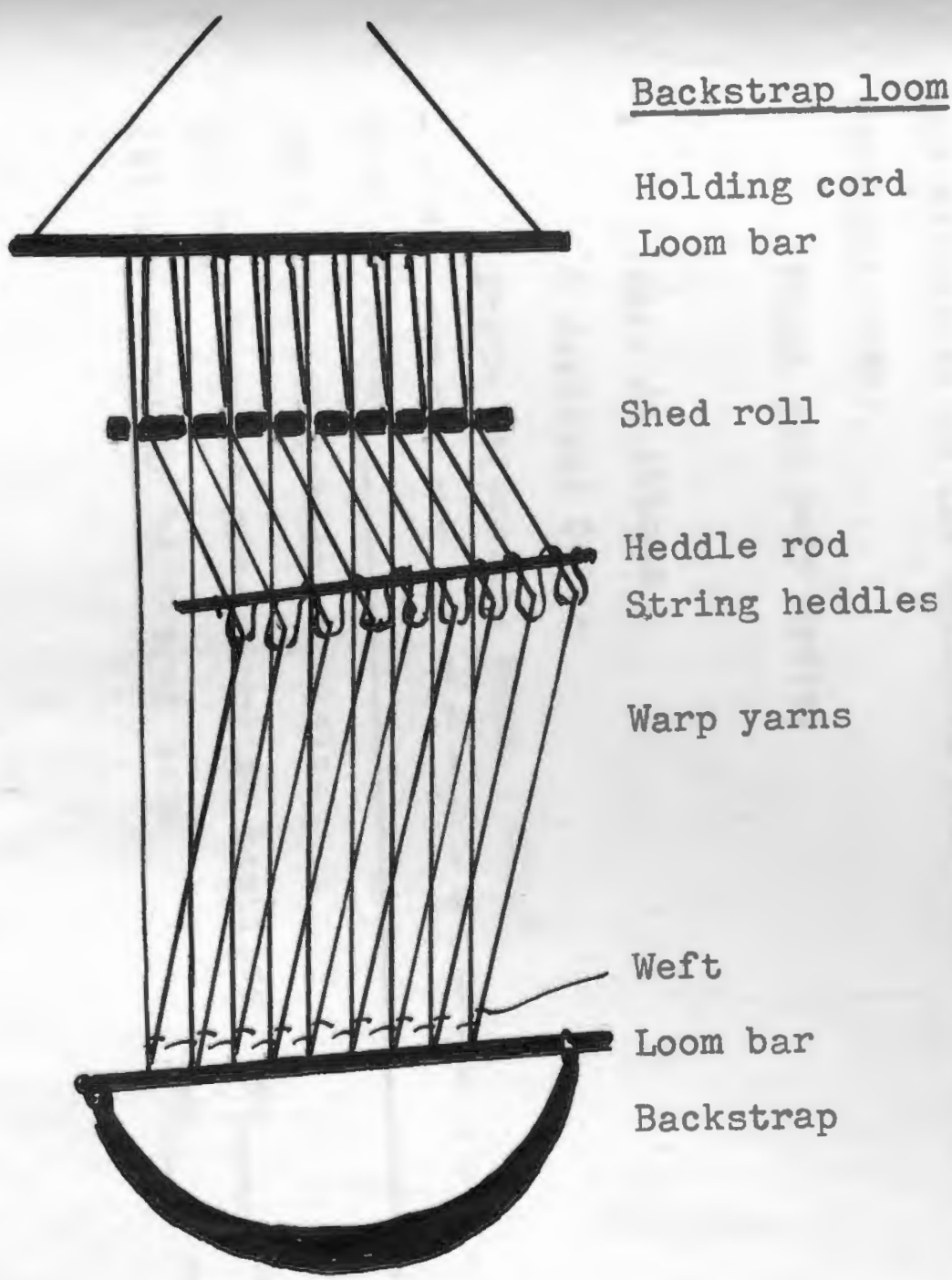

Gauze - a lace weave created by crossing selected warp yarns before inserting the weft

Open weave - a plain weave with a low warp and weft thread count

Pwill - a basic weave characterized by diagonal lines

Tapestry - a weft-face plain weave fabric in which the weft yarns are discontinuous, usually decorative and in colors

Template, Tenter - a device to maintain consistent width of fabric on the loom

Weft brocading - when a supplementary (decorative) yarn is added to a plain weave or other simple ground. The added weft can be discontinued or continuous

Warp patterning - when warp yarns, either of the ground weave or supplementary to the ground weave create the design

Source: Held, Shirley E. Weaving. New York: Holt, Rinehart and Winston, Inc., 1973. 
FOLLOW-UP LETTER TO QUESTIONNAIRE

May 19,1974

Dear Sirs:

I am a graduate student at the University of Rhode Island, Department of Textiles and Clothing, College of Home Economics and the subject of my master's thesis is "Potential and Limitations of the Peruvian Backstrap Loom."

I would appreciate if you would take a minute to answer the two questions below and return this questionnaire in the enclosed self-addressed, stamped envelope soon.

Thank you very truly,

Rosa J. Abboud

6 Heritage Drive

North Dartmouth, Mass. 02747

Name of Museum

Does your collections contain:

(1) any Peruvian pre-Columbian textiles yes__ no

(2) any Peruvian backstrap loom

yes no 
LIST OF MUSEUMS TO WHICH THE QUESTIONNAIRE ON THE PERUVIAN BACKSTRAP LOOM WAS SENT IN MARCH 1974.

1. University of Alabama Museum of Natural History. P.O. Box 5897

University of Alabama

University, Alabama 35486

2. University of Alaska Museum

University of Alaska

Fairbanks, Alaska 99701

3. Alaska State Museum

Subport, Pouch F.M. Juneau, Alaska 99801

4. University of Arkansas Museum

University of Arkansas

Fayetteville, Arkansas 72701

5. Museum of Science and Natural History

McArthur Park

Little Rock, Arkansas 72202

6. Arkansas State University

Drawer $\mathrm{H} \mathrm{H}$

State University, Arkansas 72467

7. Robert H. Lowie

Museum of Anthropology

103 Kroeber Hall

University of California

Berkeley, California 97420

8. Museum of Antiquities and Art

68-595 Plumby PI.

Hotel Arner Grounds

P.0. Box 687

Cathedral City, California 92234

9. Highland Park Southwest Museum

234 Museum Drive

Highland Park

Los Angeles, California 90065

10. Los Angeles County Museum of Art

5905 Wilshire Boulevard

Los Angeles, California 90036 
11. Museum of Cultural History

Haines Hall

University of California

Los Angeles, California 90024

12. Museum of Natural History

Los Angeles County

900 Exposition Boulevard

Los Angeles, California 90007

13. Mills College Art Gallery

Seminary \& MacArthur Boulevard

Oakland, California 94613

14. Fine Arts Gallery of San Diego

Balboa Park, P.0. Box 2107

San Diego, California 92112

15. San Diego Museum of Man

1350 El Prado

Balboa Park

San Diego, California 92101

16. M. H. de Young Memorial Museum of Art

Golden State Park

San Francisco, California 94118

17. California Palace of the Legion of Honor Lincoln Park

San Francisco, California 94118

18. The Art Galleries

University of California

Santa Barbara, California 93106

19. Santa Barbara Museum of Natural History

2559 Puesta de Sol Road

Santa Barbara, California 93105

20. Stanford University of Museum and Art Gallery

Museum Way

Stanford, California 94305

21. Pioneer Museum and Haggan Galleries

$1201 \mathrm{~N}$. Pershing Avenue

Stocton, California 95203

22. University of Colorado Museum

University of Colorado

Boulder, Colorado 80302 
23. Denver Art Museum

100 W. 14th Avenue

Denver, Colorado 80204

24. Denver Museum of Natural History

City Park

Denver, Colorado 80205

25. State Historical Society of Colorado

200 Fourteenth Avenue

Denver, Colorado 80203

26. Historical Museum and Institute of Western Colorado 4th and Ute Street

Grand Junction, Colorado 81501

27. Peabody Museum of Natural History

170 Whitney Avenue

New Haven, Connecticut 06520

28. Yale University Art Gallery

Chapel Street

New Haven, Connecticut 06520

29. Museum of Art

The University of Connecticut

Storrs, Connecticut 06268

30. DuPont Henry Francis

Winterthur Museum

Winterthur, Delaware 19735

31. Dumbarton Oaks Research Library and Collection

1703 32nd Street, N.W.

Washington, D.C. 20007

32. National Geographic Society

Explorers Hall

17 th and M Streets, N.W.

Washington, D.C. 20560

33. Corcoran Gallery of Art

Washington, D.C. 20560

34. National Museum of History and Technology,

Division of Textiles

Smithsonian Institute

1000 Jefferson Drive, S.W.

Washington, D.C. 20560

35. National Museum of Natural History

Smithsonian Institute

1000 Jefferson Drive, S.W.

Washington, D.C. 20560 
36. Textile Museum

2320 S. Street, N.W.

Washington, D.C. 20008

37. Lowe Art Museum

University of Miami

1301 Miller Drive

Coral Gables, Florida 33146

38. Florida State Museum

University of Florida

Gainesville, Florida 32601

39. Emory University Museum

Arkwright Drive

Emory University

Atlanta, Georgia 30322

40. University of Idaho Museum

Moscow, Idaho 83843

41. Idaho State University Museum

Box 8096

Poccatello, Idaho 83209

42. Herrett Arts and Science Center

1220 Kimberly Road

East Five Points

Twill Falls, Idaho 83301

43. University Museum

Southern Illinois University

Carbondale, Illinois 62901

44. Art Institute of Chicago

Michigan Avenue at Adams Street

Chicago, Illinois 60603

45. Field Museum of Natural History Roosevelt Road, Lake Shore Drive Chicago, Illinois 60605

46. Illinois State Museum

Corner Spring and Edwards Street

Springfield, Illinois 62706

47. Museum of Natural History

University of Illinois

Matthews and Green Streets

Urbana, Illinois 61801 
48. World Heritage Museum University of Illinois 484 Lincoln $\mathrm{Hall}$ Urbana, Illinois 61801

49. Indiana University Art Museum

Fine Arts Building, Room 007

Bloomington, Indiana 47401

50. Indiana University Museum

Student Building 107

Indiana University

Bloomington, Indiana 47401

51. Art Gallery, University of Notre Dame

O'Shaugnessy Hall

University of Notre Dame

Notre Dame, Indiana 46556

52. University of Northern Iowa Museum

31 st and Hudson Road

Cedar Falls, Iowa 50613

53. Davenport Museum

1717 West 12th Street

Davenport, Iowa 52804

54. Museum of Anthropology

University of Kansas

Lawrence, Kansas 66044

55. University of Kansas Museum of Art

University of Kansas

Lawrence, Kansas 66044

56. Wichita Art Museum

619 Stackman Drive

Wichita, Kansas 67203

57. J.B. Speed Art Museum

2035 S. Third Street

Louisville, Kentucky 40208

58. Museum of Geoscience

Louisiana State University

Baton Rouge, Louisiana 70803

59. Louisiana State Museum

751 Chartres Street

New Orleans, Louisiana 70116 
60. New Orleans Museum of Art

P.0. Box 19123

New Orleans, Louisiana 70179

61. Maine State Museum

State House

Augusta, Maine 04330

62. Bowdoin College Museum of Art

Walker Art Building

Brunswick, Maine 04011

63. Museum of Art and Archaeology

University of Missouri

Library $4 \mathrm{D} 11$

Columbia, Maine 65201

64. Anthropology Museum

University of Maine

Orono, Maine 04473

65. Baltimore Museum of Art

Art Museum Drive

Baltimore, Maryland 21218

66. John Hanson Memorial Museum

6701 Oxon Hill Road

Oxon, Maryland 20021

67. Addison Gallery of American Art

Phillips Academy

Andover, Massachusetts 01810

68. Museum of Fine Arts

Boston, Massachusetts 02115

69. Fogg Art Museum

32 Quincy Street

Harvard University

Cambridge, Massachusetts 02138

70. Peabody Museum of Archaeology and Ethnology

11 Divinity Avenue

Cambridge, Massachusetts 02138

71. Robert S. Peabody Foundation for Archaeology Corner of Phillips and Main Street

Andover, Massachusetts 01810 
72. Merrimack Valley Textile Museum

P.0. Box 266

North Andover, Massachusetts 01845

73. Crysler Art Museum

Corner Commercial and Center Street

Provincetown, Massachusetts 02657

74. Peabody Museum of Salem

161 Essex Street

Salem, Massachusetts 01970

75. Worcester Art Museum

55 Salisbury Street

Worcester, Massachusetts 01608

76. Museum of Anthropology

University of Michigan

Ann Arbor, Michigan 48104

77. The University of Michigan Museum of Art Alumni Memorial Hall

Ann Arbor, Michigan 48104

78. Cranbrook Academy of Art

500 Lone Pine Road

Bloomfield Hills, Michigan 48013

79. Cranbrook Institute of Science

500 Lone Pine Road

Box 807

Bloomfield Hills, Michigan 48013

80. Detroit Institute of Arts

5200 Woodward Avenue

Detroit, Michigan 48202

81. Wayne State University Museum of Anthropology

Merrick and Anthony Drive

Detroit, Michigan 48202

82. Kresge Art Center Gallery

Michigan State University

East Lansing, Michigan 48823

83. The Museum

Michigan State University

West Circle Drive

East Lansing, Michigan 48823 
84. The University Art Gallery

Oakland University

Rochester, Michigan 48063

85. The Minneapolis Institute of Arts

201 E. 24th Street

Minneapolis, Minnesota 55404

86. University Gallery

University of Minnesota

316 Northrop Memorial Auditorium

Minneapolis, Minnesota 55455

87. The Science Museum of Minnesota

30 E. 10th Street

St. Pau, Minnesota 55101

88. University of Missouri

Museum of Art and Archaeology

Ellis Library 4D 11

Columbia, Missouri 65201

89. William Rockhill Nelson Gallery and Atkins Museum of Fine Arts 4525 Oak Street

Kansas City, Missouri 64111

90. The St. Louis Art Museum

Forest Park Street

St. Louis, Missouri 63110

91. University of Nebraska State Museum 101 Morrill Hall

14 th and U. Street

Lincoln, Nebraska 68608

92. Morris Museum of Arts and Sciences Normandy Heights and Columbia Roads Morristown, New Jersey 07960

93. The Newark Museum

49 Washington Street

Newark, New Jersey 07101

94. Herbert Lewis Taylor

Archaeological Museum and Library

739 W. 8th Street

Plainfield, New Jersey 07060 
95. The Art Museum

Princeton University

Princeton, New Jersey 08540

96. Roswell Museum and Art Center

100 West 1lth Street

Roswell, New Mexico 88201

97. Museum of New Mexico

P.0. Box 2087

Santa Fe, New Mexico 87501

98. University Art Gallery

State University of New York at Binghamton

Binghamton, New York 13901

99. The Brooklyn Museum

188 Eastern Parkway

Brooklyn, New York 11238

100. Buffalo Museum of Science

Humboldt Park

Buffalo, New York 14211

101. Albright-Knox Art Gallery

The Buffalo Fine Arts Academy

1285 Elmwood Avenue

Buffalo, New York 14222

102. Mohawk-Caughnawaga Museum

Tatatwitha Friary

R.D. 1, Box 6

Fonda, New York 12068

103. The Picker Gallery

Charles A. Dana Creative Arts Center

Colgate University

Hamilton, New York 13346

104. Emily Lowe Gallery

Hofstra University

Hempstead, New York 11550

105. Herbert F. Johnson Museum of Art

Cornell University

Ithaca, New York 14850

106. The American Museum of Natural History

79 th and Central Park West

New York, New York 10024 
107. Cooper-Hewitt Museum of Decorative Arts and Design 9 East 90th Street New York, New York 10028

108. The Metropolitan Museum of Art

5 th Avenue at 82 Street

New York, New York 10028

109. Museum of Primitive Art

15 W. 54th Street

New York, New York 10019

110. Museum of the American Indian

Heye Foundation

Broadway at 155th Street

New York, New York 10032

111. Scalamandre, Museum of Textiles

201 E. 58 th Street

New York, New York 10022

112. Yager Museum of Hartwick College

Hartwick College

Oneonta, New York 13820

113. Memorial Art Gallery of the University of Rochester 490 University Avenue

Rochester, New York 14607

114. Rochester Museum and Science Center

657 East Avenue

Rochester, New York 14607

115. Joe and Emily Lowe Art Center

Syracuse University

309 University Palce

Syracuse, New York 13210

116. Research Laboratories of Anthropology

Person $\mathrm{Hall}$

University of North Carolina at Chapel Hill

Chapel Hill, North Carolina 27514

117. William Hayes Ackland Art Center

Columbia and Franklin Street

University of North Carolina

Chapel Hill, North Carolina 27514

118. Weatherspoon Art Gallery

University of North Carolina at Greensboro

Greensboro, North Carolina 27412 
119. North Carolina Museum of History 109 E. Jones Street Raleigh, North Carolina 27611

120. Akron Art Institute 69 Market Street Akron, Ohio 44308

121. Cincinnati Art Museum Eden Park Cincinnati, Ohio 45202

122. Cincinnati Museum of Natural History 1720 Gilbert Avenue Cincinnati, Ohio 45202

123. Cleveland Museum of Art 11150 East Boulevard Cleveland, Ohio 44106

124. Cleveland Museum of Natural History Wade Oval University Circle Cleveland, Ohio 44106

125. Columbus Gallery of Fine Arts 480 E. Broad Street Columbus, Ohio 43215

126. Dayton Art Institute Forest and Riverview Avenue Dayton, Ohio 45401

127. Dayton Museum of Natural History 2629 Ridge Avenue Dayton, Ohio 45414

128. Denison University Gallery Department of Art Denison University Granville, Ohio 43023

129. East Central State College Museum Ada, Oklahoma 74820

130. Stovall Museum of Science and History University of Oklahoma 1335 Asp Street Norman, Oklahoma 73069 
131. Oklahoma Science and Arts Foundation 3000 Pershing Boulevard Fair Park

Oklahoma City Oklahoma 73116

132. Museum of Natural History

University of Oregon

Eugene, Oregon 97403

133. Portland Art Museum

1219 S.W. Park Avenue

Portland, Oregon 97205

134. Blumhaven Library and Gallery

4651 Leiper Street

Philadelphia, Pennsylvania 19124

135. Drexel Museum Collection, Drexel University 32nd Chestnut Street

Philadelphia, Pennsylvania 19104

136. Moore College of Art Gallery

20th and Race Street

Philadelphia, Pennsylvania 19130

137. Philadelphia Museum of Art

26th Street and Benjamin Franklin Parkway

Philadelphia, Pennsylvania 19101

138. The University Museum

33rd and Spruce Street

Philadelphí, Pennsylvania 19174

139. Carnegie Museum of Natural History P.0. Box 28, Meridian Butler

140. University of Pittsburgh

University Art Gallery

Henry Clay Frick Fine Arts Building

Pittsburgh, Pennsylvania 15213

141. Everhart Museum of Natural History

Nay Aug. Park

Scranton, Pennsylvania 18510

142. Museum of Art, The Pennsylvania State University College of Arts and Architecture

University Park, Pennsylvania 16802 
143. Brooks Memorial Art Gallery

Overton Park

Memphis, Tennessee 38112

144. Dallas Museum of Fine Arts

Fair Park

Dallas, Texas

145. Texas Women's University Art Galleries

1 Circle Drive

Denton, Texas 76026

146. El Paso Museum of Art

1211 Montana Avenue

El Paso, Texas 79902

147. Fort Worth Museum of Science and History

1501 Montgomery Street

Fort Worth, Texas 76107

148. Kimbell Art Museum

Will Rogers Road

Fort Worth, Texas 76107

149. The Museum of Fine Arts Houston

1001 Bissonnet, P.0. Box 6826

Houston, Texas 77005

150. Robert Hull Fleming Museum

Colchester Avenue

Burlington, Vermont

151. Johnson Gallery of Middlebury College Middlebury, Vermont 05753

152. The College Museum, Hampton Institute Hampton, Virginia 23368

153. Chrysler Museum at Norfolk

Olney Road

Norfolk, Virginia 23510

154. Virginia Museum of Fine Arts

Boulevard and Grove Avenue

Richmond, Virginia 23221

155. Museum of Anthropology

Department of Anthropology

Washington State University

Pullman, Washington 99163 
156. Costume and Textile Study Center

School of Home Economics

University of Washington

Seattle, Washington 98105

157. Seattle Art Museum

Volunteer Park

Seattle, Washington 98102

158. Logan Museum of Anthropology

Beloit College

Beloit, Wisconsin 53511

159. Elvehjem Art Center

800 University Avenue

Madison, Wisconsin 53706

160. Milwaukee Art Center

750 N. Lincoln Memorial Drive

Milwaukee, Wisconsin 53202

161. Milwaukee Public Museum

800 W. Wells Street

Milwaukee, Wisconsin 53233

162. University of Wyoming

Anthropology Museum

Arts and Science Building

Laramie, Wyoming 82070

163. Mrs. Eleanore A. Fayerweather

Curator, Costume Center

Museum of Art

Rhode Island School of Design

224 Benefit Street

Providence, Rhode Island 02903

164. Dr. Jane P. Dwyer

Director Haffenreffer Museum of Anthropology

Mt. Hope Grant

Bristol, Rhode Island

165. Royal Ontario Museum of Archaeology

Toronto, Canada

166. Victoria and Albert Museum

London SW 7, Great Britain

167. Museum of Arts and Crafts

University of Manchester

Manchester MI3 9PL Great Britain 
168. Mrs. Sandra Harner

7 Twin Falls Lane

Westport, Connecticut

169. Mrs. Joseph Bastien

Department of Anthropology

Cornell University

Ithaca, New York

170. Huntington Library

San Marino, Californià

171. Krannert Art Museum

University of Illinois

Champaign, Illinois 61820

172. Dr. Dieter Eisleb

Museum fuer Voelkerkunde

Abteilung Amerikanische Archaeologie

1 Berlin 33 - Dahlen

Arminallee 23/27

173. $\mathrm{Mr}$. Edouard Versteylen

Museo Nacional de Anthropologia

Arqueologia, Plaza Principal

Pueblo Libre, Peru

174. Director, Museo National de la Cultura Peruana

Auda, Alfonso Ugarte 650

Lima, Peru

175. Director, Bankfield Museum

Ackroyd Park

Halifax, Yorkshire

England

176. Director, British Museum, Department of Ethnology

The Horniman Museum

London Road

Forest Hill

London, SE $233 \mathrm{~Pa}$, England 
COMBINED LIST OF MUSEUM VISITS AND RESOURCE

PERSONS WHO OFFERED ASSISTANCE

DURING THIS STUDY

\begin{tabular}{|c|c|c|c|}
\hline $\begin{array}{l}\text { Number } \\
\text { assigned } \\
\text { to museum } \\
\text { in survey }\end{array}$ & Museum & Location & $\begin{array}{l}\text { Resource } \\
\text { person }\end{array}$ \\
\hline \multicolumn{4}{|c|}{ Visits } \\
\hline 106 & $\begin{array}{l}\text { American Museum } \\
\text { of Natural } \\
\text { History }\end{array}$ & New York & $\begin{array}{l}\text { Dr. Junius B. } \\
\text { Bird; Milica } \\
\text { Skinner }\end{array}$ \\
\hline 164 & $\begin{array}{l}\text { Haffenreffer } \\
\text { Museum of } \\
\text { Anthropology, } \\
\text { Brown University }\end{array}$ & $\begin{array}{l}\text { Bristol, } \\
\text { R. I. }\end{array}$ & $\begin{array}{l}\text { Dr. Jane Dwyer; } \\
\text { Barbara Hail }\end{array}$ \\
\hline 108 & $\begin{array}{l}\text { Metropolitan } \\
\text { Museum of Art }\end{array}$ & New York & Barbara Teague \\
\hline 110 & $\begin{array}{l}\text { Museum of the } \\
\text { American Indian }\end{array}$ & New York & \\
\hline 163 & $\begin{array}{l}\text { Museum of Art, } \\
\text { Providence }\end{array}$ & $\begin{array}{l}\text { Providence, } \\
\text { R. I. }\end{array}$ & $\begin{array}{l}\text { Eleanore } \\
\text { Fayerweather }\end{array}$ \\
\hline 68 & $\begin{array}{l}\text { Museum of Fine } \\
\text { Arts, Boston }\end{array}$ & $\begin{array}{l}\text { Boston, } \\
\text { Mass. }\end{array}$ & Larry Salmon \\
\hline 35 & $\begin{array}{l}\text { National Museum } \\
\text { of Natural } \\
\text { History, Smith- } \\
\text { sonian Institute }\end{array}$ & $\begin{array}{l}\text { Washington, } \\
\text { D.C. }\end{array}$ & $\begin{array}{l}\text { Barbara } \\
\text { Stuckenrath }\end{array}$ \\
\hline 70 & $\begin{array}{l}\text { Peabody Museum of } \\
\text { Archaeology and } \\
\text { Ethnology, } \\
\text { Harvard University }\end{array}$ & $\begin{array}{l}\text { Cambridge, } \\
\text { Mass. }\end{array}$ & $\begin{array}{l}\text { Joanne } \\
\text { Brandford }\end{array}$ \\
\hline 27 & $\begin{array}{l}\text { Peabody Museum of } \\
\text { Natural History, } \\
\text { Yale University }\end{array}$ & $\begin{array}{l}\text { New Haven, } \\
\text { Conn. }\end{array}$ & \\
\hline 36 & Textile Museum & $\begin{array}{l}\text { Washington, } \\
\text { D.C. }\end{array}$ & Ann P. Rowe \\
\hline 75 & $\begin{array}{l}\text { Worcester Art } \\
\text { Museum }\end{array}$ & $\begin{array}{l}\text { Worcester, } \\
\text { Mass. }\end{array}$ & $\begin{array}{l}\text { Stephen } \\
\text { Jareckie }\end{array}$ \\
\hline
\end{tabular}


COMBINED LIST OF MUSEUM VISITS AND RESOURCE

PERSONS -- Continued

\begin{tabular}{|c|c|c|c|}
\hline $\begin{array}{l}\text { Number } \\
\text { assigned } \\
\text { to museum } \\
\text { in survey }\end{array}$ & iTuseum & Location & $\begin{array}{l}\text { Resource } \\
\text { person }\end{array}$ \\
\hline \multicolumn{4}{|c|}{ Correspondence } \\
\hline 157 & $\begin{array}{l}\text { Museum of Arts } \\
\text { and Crafts, } \\
\text { University of } \\
\text { Manchester }\end{array}$ & $\begin{array}{l}\text { Manchester, } \\
\text { Great Britain }\end{array}$ & Kathleen Hunt \\
\hline 132 & $\begin{array}{l}\text { Museum of } \\
\text { Natural History, } \\
\text { University of } \\
\text { Oregon }\end{array}$ & $\begin{array}{l}\text { Eugene, } \\
\text { Oregon }\end{array}$ & $\begin{array}{l}\text { Dr. Ina } \\
\text { Vanstan }\end{array}$ \\
\hline 97 & $\begin{array}{l}\text { Museum of New } \\
\text { Mexico }\end{array}$ & $\begin{array}{l}\text { Santa Fe, } \\
\text { New Mexico }\end{array}$ & Nora Fisher \\
\hline 172 & $\begin{array}{l}\text { Museum fuer } \\
\text { Voelkerkunde }\end{array}$ & $\begin{array}{l}\text { Berlin, } \\
\text { Germany }\end{array}$ & $\begin{array}{l}\text { Dr. Dieter } \\
\text { Eisleb }\end{array}$ \\
\hline
\end{tabular}


SUMMARY OF QUESTIONTAIRE

(PART: LOOMS)

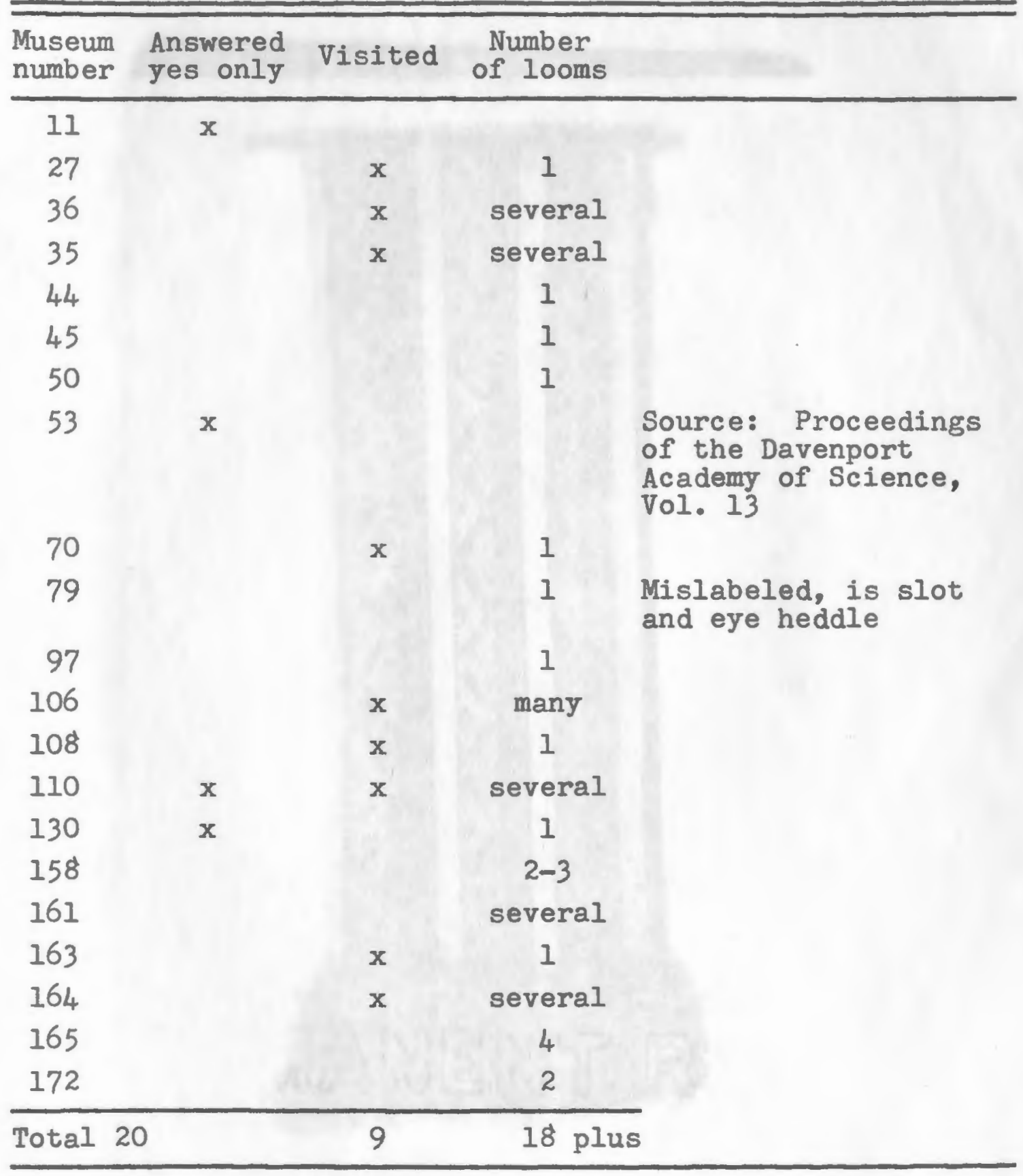

Note: In addition the following two museums which had only Peruvian textiles were visited: No. $68^{\circ}$ and 75 . 


\section{$A-602-E$}

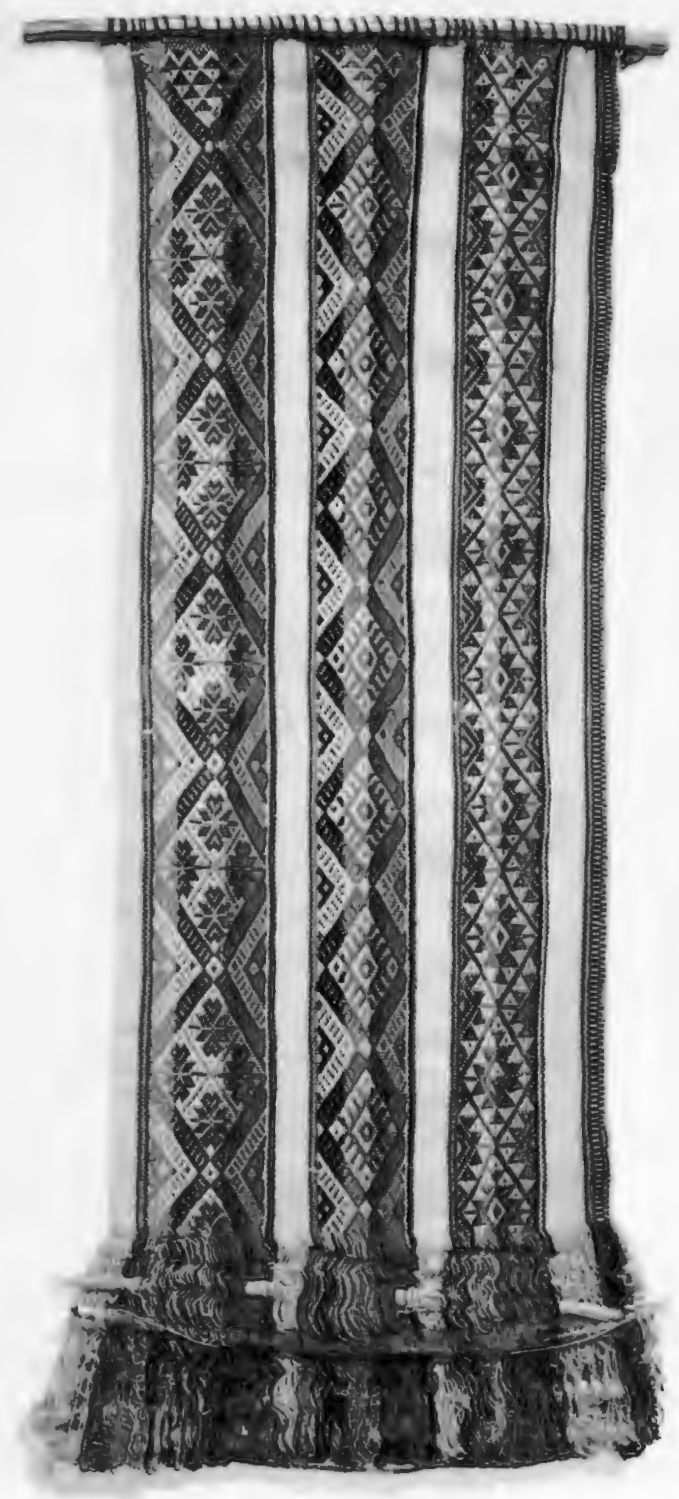

Figure 25. Mislabeled specimen. 